\title{
th. 424
}

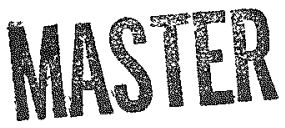

GA-A14838

UC-77

\section{HTGR FUEL ELEMENT SIZE REDUCTION SYSTEM}

\section{INTERIM DEVELOPMENT REPORT}

by

J. B. STRAND and G. T. CRAMER

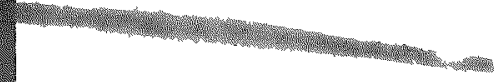

- Repared under

Contract EY-76-C-03-0167

Project Agreement No. 53

for the San Francisco Operations Office

Department of Energy

DATE PUBLISHED: JUNE 1978

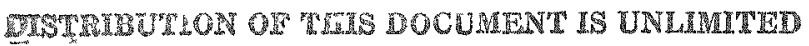

\section{GENERAL ATOMIC COMPANY}


This report was prepared as an account of work sponsored by the United States Government. Neither the United States nor the Department of Energy, nor any of their employees, nor any of their contractors, subcontractors, or their employees, makes any warranty, express or implied, or assumes any legal liability or responsibility for the accuracy, completeness or usefulness of any information, apparatus, product or process disclosed, or represents that its use would not infringe privately owned rights.

Printed in the United States of America Available from

National Technical Information Service

U.S. Department of Commerce

5285 Port Royal Road

Springfield, Virginia 22161

Price: Printed Copy $\$ 9.50 ;$ Microfiche $\$ 3.00$ 


\section{DISCLAIMER}

This report was prepared as an account of work sponsored by an agency of the United States Government. Neither the United States Government nor any agency Thereof, nor any of their employees, makes any warranty, express or implied, or assumes any legal liability or responsibility for the accuracy, completeness, or usefulness of any information, apparatus, product, or process disclosed, or represents that its use would not infringe privately owned rights. Reference herein to any specific commercial product, process, or service by trade name, trademark, manufacturer, or otherwise does not necessarily constitute or imply its endorsement, recommendation, or favoring by the United States Government or any agency thereof. The views and opinions of authors expressed herein do not necessarily state or reflect those of the United States Government or any agency thereof. 


\section{DISCLAIMER}

Portions of this document may be illegible in electronic image products. Images are produced from the best available original document. 


\title{
HTGR FUEL ELEMENT SIZE REDUCTION SYSTEM
}

\section{INTERIM DEVELOPMENT REPORT}

by

J. B. STRAND and G. T. CRAMER

This report was prepared as an account of work sponsored by the United States Government Nerther the United States nor the United States Department of Energy, nor any of therr employees, nor any of therr contractors, subcontractors, or their employees, makes labuluty or responsbluty for the acoury as any legal or usefulness of any uformation, appartus, product or process discose or process disclosed, or represents that its use would not
infringe prvately owned nights

\author{
Prepared under \\ Contract EY-76-C-03-0167 \\ Project Agreement No. 53 \\ for the San Francisco Operations Office \\ Department of Energy
}

GENERAL ATOMIC PROJECT 3261

DATE PUBLISHED: JUNE 1978 



\section{ABSTRACT}

Reprocessing of high-temperature gas-cooled reactor fuel requires development of a fuel element size reduction system. This report describes pilot plant testing of crushing equipment designed for this purpose. The test program, the test results, the compatibility of the components, and the requirements for hot reprocessing are discussed. 
$\mid$

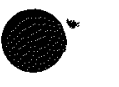

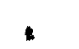

○.

.

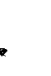

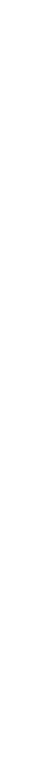

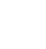

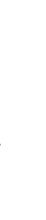


CONTENTS

ABSTRACT ....................... . . . . . . . . . . . . .

1. INTRODUCTION ........................ 1-

1.1. Phase I: Demonstration of Major Equipment Item

Capabilities and Their Interaction with Subsystems . . . 1-3

1.2. Phase II: Demonstration of UNIFORM System

Capabilities and Its Interaction with Subsystems . . . . 1-4

1.3. Phase III: Demonstration of Fue1-Loaded Element

Crushing and Fuel Particle Breakage Determination . . . . 1-5

2. EQUTPMENT DESCRIPTION . . . . . . . . . . . . 2-1

2.1. Primary Crusher . . . . . . . . . . . . 2-1

2.2. Secondary Crusher ................ 2-1

2.3. Tertiary Crusher . . . . . . . . . . . . 2-3

2.4. Oversize Monitoring System ............ 2-3

2.5. Ventilation Enclosure .............. 2-4

2.6. Drive System . . . . . . . . . . . 2-4

2.7. Structural Machine Frame ........... . 2-4

2.8. Remote Fixtures ............. 2-4

2.9. References .............. 2- 24

3. PHASE I TESTS ....................... 3- . . .

3.1. Introduction ................ 3-1

3.2. Primary Crusher Tests . . . . . . . . . . . 3-1

3.3. Secondary Crusher Tests . . . . . . . . . 3-15

3.3.1. Test Activities . . . . . . . . . 3-15

3.3.2. Secondary Crusher Modifications . . . . . . 3-26

3.4. Tertiary Crusher Testing .......... . . 3-26

3.5. Oversize Crusher Testing ........... 3-32

3.6. Screener Testing ............. 3-37

3.7. Remote Handling System . . . . . . . . . . . 3-55

3.7.1. Prototype Size Reduction System

Component Handling Fixtures . . . . . . . 3-55 
3.7.2. Crusher Shroud Shutoff Valve . . . . . . 3-56

3.7.3. Secondary Pitman Lift Fixture... . . . . . 3-56

3.8. References ............. . . 3-64

4. PHASE II: UNIFRAME SYSTEM TESTS WITH UNFUELED ELEMENTS $\cdot$ • • • • 4-1

4.1. Modified Secondary Crusher Shakedown . . . . . . . 4-1

4.2. System Shakedown . . . . . . . . . . . . . 4-3

4.3. System Tests . . . . . . . . . . . . 4-6

4.3.1. Equipment Operation and Test Observations . . . 4-8

4.3.2. Material Balances .......... 4-8

4.3.3. Crushing Rates ............. 4-10

4.3.4. Relative Quantities of Screener and

Oversize Crusher Product . . . . . . . . 4-12

4.3.5. Product Characteristics . . . . . . . . . 4-14

4.4. Phase II Acceptance Criteria . . . . . . . . . 4-39

4.4.1. Material Holdup: $\leq 0.5 \%$ of Throughput ..... 4-39

4.4.2. Throughput Rate: One Fuel Element in $\leq 15$ Min . . 4-39

4.4.3. Crushed Material Confinement (Excluding Dusts):

$100 \%$ to Crushing and Screening Cavities . . . 4-40

4.4.4. Crushed Product: $\leq 4750-\mu \mathrm{m}$ Ring Size with a Size

Distribution Suitable for Primary Burner Feed . . 4-40

4.4.5. Dust Confinement: $100 \%$ to Ventilation Enclosure - 4-41

5. UNIFRAME SCRAP GRAPHITE CRUSHING TESTS . . . . . . . . . . . 5-1

5.1. Introduction . . . . . . . . . . . . . 5-1

5.2. Shakedown Tests . . . . . . . . . . . . . 5-1

5.3. Scrap Graphite Crushing . . . . . . . . . . . . 5-6

5.4. S1ot Valve Tests . . . . . . . . . . . . 5-23

6. PHASE III: UNIFRAME SYSTEM TESTS WITH FUELED ELEMENTS.$\cdot$. • 6-1

6.1. Introduction ... . . . . . . . . . . 6-1

6.2. Fuel Materials ............... . 6-1

6.3. Operating Procedures . . . . . . . . . . . . 6-1

6.4. Equipment Operation and Test Observations . . . . . . 6-2

6.5. Processing Times ............ . . 6-3

6.6. Material Balances . . . . . . . . . . . 6-4

6.7. Relative Quantities of Screener and Oversize
Crusher Product . . . . . . . . . . 6-4 
6.8. Product Characteristics .......... 6- 6-7

6.8.1. Screener Product Size Distributions ..... 6-18

6.8.2. Oversize Crusher Product Size Distributions . . 6-18

6.8.3. Composite Screener and Oversize Crusher

Products . . . . . . . . . . . 6-21

6.8.4. Comparison of Crushed Product with Primary

Burner Feed Requirements . . . . . . 6-21

6.9. Particle Breakage ............ 6- 6-28

6.9.1. Analytical Procedure . . . . . . . 6-28

6.9.2. Results ........... 6- 6- . . . . .

6.10. Phase III Acceptance Criteria ....... 6- . . 6-33

7. PILOT PLANT SEQUENTIAL OPERATION: UNIFRAME SYSTEM TESTS

WITH FUELED ELEMENTS ............... . . . . 7-1

8. CONCLUSIONS AND RECOMMENDATIONS . . . . . . . . . 8-1

8.1. Designs Requiring Modification for Hot Cell Use . . . 8-1

8.1.1. Ventilation Enclosure ......... 8-1

8.1.2. Crushing Wear Surfaces ........ 8-2

8.2. Designs Requiring Completion for Hot Cell Use ..... 8-2

8.2.1. Through-the-Cell-Wall Drive System ..... 8-2

8.2.2. Start-Under-Load Capability . . . . . 8-3

8.2.3. Fuel Loading Port ........... 84

8.2.4. Lubrication Systems . . . . . . . 8-4

8.2.5. Interchangeability of Pitman Parts . . . . 8-5

8.2.6. Secondary Crusher Clearing Device..... 8-6

8.2.7. Oversize Crusher ......... 8- . 8-6

8.3. Designs Requiring Evaluation ......... 8-7

8.3.1. Primary Crusher Clearing Device ...... 8-7

8.3.2. Variable Primary Crusher Nip Angle ..... 8-8

8.3.3. Removable Primary and Secondary Crusher

8.3.4. Fixed Close Side Settings, Primary and . . . . . 8- 8- . . .

8.3.5. Oversize Monitoring System ....... 8-20

8.4. Summary . . . . . . . . . . . 8-32

9. ACKNOWLEDGMENTS .................... . . . . . . . . .

APPENDIX A: DESIGN CRITERIA FOR FUEL ELEMENT SIZE REDUCTION SYSTEM - A-1 
2-1. UNIFRAME size reduction system (less drives and enclosures) . . 2-2

3-1. Primary pitman toggle shaft (dry film lubricant removed from bottom half of shaft) . . . . . . . ..... . 3-3

3-2. Primary crusher toggle shaft showing absence of substrate damage .. . . . . . . . . . . . 3-4

3-3. Primary crusher stationary jaw showing modifications and entry chute . . . . . . . . . . . . . . . . 3-8

3-4. Primary pitman assembly showing chamfered side plates . . . . 3-8

3-5. Product size distributions in half-size H-327 fuel element tests............... . . 3-13

3-6. Product size distributions in ful1-size $\mathrm{H}-327$ fuel element tests............... . . 3-14

3-7. Product size distributions in UNIFRAME primary crusher tests . 3-16

3-8. Weight percent of each size fraction in UNIFRAME primary crusher tests . . . . . . . . . . . . 3-17

3-9. +15-cm ring size material from test PC-2: primary crushing of an unfueled half-size $\mathrm{H}-327$ fuel element . . . . . . . 3-19

3-10. +15-cm ring-size material from test PC-4: primary crushing of an unfueled half-size $\mathrm{H}-327$ control rod element . . . . 3-19

3-11. Formation of bridges in fuel element fragments: (top) bridged fragments in test SC-15; (bottom) typical interlocking to form bridges .......... . . 3-23

3-12. Secondary crusher modification showing deeper crushing cavity and 14-deg nip angle ............ 3-27

3-13. Secondary crusher pitman assembly with original wear plate • 3-28

3-14. Secondary crusher pitman assembly with modified wear plate and machined flat . . . . . . . . . . . . . 3-28

3-15. -5512- $\mu \mathrm{m}$ product size distributions from UNIFRAME tertiary crusher phase I tests . . . . . . . . . . . 3-34

3-16. Screener with perforated plate modified for blinding tests . 3-39

3-17. Screener with perforated plate removed ......... 3-39

3-18. Screener showing 4750- $\mu \mathrm{m}$ wire mesh screen installed . . . . . 3-40

3-19. Screener with self-cleaning kit installed (screen removed) . . 3-40

3-20. Calculated UNIFRAME system crushed product distribution versus primary burner "acceptable feed" distribution . . . . 3-50

3-21. Crusher shroud shutoff valve . . . . . . . . . . 3-57

3-22. Secondary pitman lift fixture . . . . . . . . . . 3-58 
3-23. Toggle lift hook drive assembly: secondary pitman

lift fixture ............... 3-59

3-24. Upper limit switch positioning: secondary pitman

lift fixture .................. . 3-60

3-25. Worm drive assemb1y: secondary pitman 1ift fixture . . . . 3-60

3-26. Secondary pitman jaw showing lubrication drain valve damage • 3-62

3-27. Secondary pitman 1ift fixture . . . . . . . . . . . 3-63

4-1. Screener product comparison by mesh size: phase II tests . . 4-18

4-2. Screener product comparison by cumulative weight percent:

phase II tests . . . . . . . . . . . . . . 4-22

4-3. Oversize crusher product comparison by mesh size:

phase III tests... . . . . . . . . . . . . 4-24

4-4. Oversize crusher product comparison by cumulative weight

percent: phase II tests ............. 4-26

4-5. UNIFRAME composite product comparison by mesh size:

phase II tests ............... . 4-30

4-6. UNIFRAME composite product comparison by cumulative

weight percent: phase II tests . . . . . . . . . . 4-33

4-7. Size distributions of products from tertiary crushing

and UNIFRAME system ................. 4-35

4-8. Comparison of UNIFRAME composite high and low valves with

those for "acceptable" burner feed . . . . . . . . . 4-38

5-1. Screener product comparison: fuel elements and scrap

graphite .. . . . . . . . . . . . . . . 5-4

5-2. Oversize crusher product comparison: fuel elements and scrap graphite . . . . . . . . . . . . . 5-5

5-3. Product transport 1ine blockage: test SCRAP-3 . . . . . 5-8

5-4. Product transport arrangement: tests SCRAP-4 through

SCRAP-9..................... 5-9

5-5. Composite product comparison: fuel elements and scrap graphite .................. . 5-11

5-6. Product transport arrangement: tests SCRAP-10 through SCRAP-18 (showing product transport line blockage of tests SCRAP-10 and SCRAP-11) ............ 5-14

5-7. Effect of transport on combined screener and oversize crusher products .................. 5-18

5-8. Product transport arrangement: tests SCRAP-19 through SCRAP-21 and crushing of HTGR fuel element I-2319 . . . . . 5-21

5-9. Oversize crusher slot valve . . . . . . . . . . 5-24

6-1. Screener product comparison: phase III tests . . . . . . . 6-12

6-2. Screener product comparison: phase II and III tests . . . 6-13 
6-3. Oversize crusher product comparison: phase III tests . . . 6-19

6-4. Oversize crusher product comparison: phase II and III tests . 6-20

6-5. Composite product comparison: phase III tests . . . . . . 6-26

6-6. Composite product comparison: phase II and III tests . . . 6-27

6-7. Comparison of composite product with "acceptable"

burner feed ................ 6- 6-29

8-1. Basic components of primary crusher nip angle adjustment . . 8-9

8-2. Basic components of removable and reversible primary crusher stationary jaw . . . . . . . . . . . 8-12

8-3. Basic components of removable and reversible secondary crusher stationary jaw........... 8-13

8-4. Simplified illustration of components determining the close side setting (typical of primary and secondary crushers) ............... 8-19

8-5. Oversize monitoring system . . . . . . . . . . . 8-21

8-6. Cutaway of screener . . . . . . . . . . 8-22

8-7. Flow rate sensor . . . . . . . . . . . . . 8-23

8-8. Cutaway of oversize crusher . . . . . . . . . . 8-24

\section{TABLES}

1-1. Experiments for phase I tests . . . . . . . . . . 1-4

1-2. Experiments for phase II tests............. 1-4

1-3. Experiments for phase III tests ............. 1-5

3-1. UNIFRAME primary crusher phase I parametric studies . . . . 3-6

3-2. UNIFRAME primary crusher phase I product characteristics . . . 3-10

3-3. UNIFRAME primary crusher product characterization

studies .................. 3-12

3-4. UNIFRAME primary crusher tests - characteristics of material greater than $15 \mathrm{~cm}$ (6 in.) ring size ...... . 3-18

3-5. UNIFRAME secondary crusher operation tests . . . . . . . 3-20

3-6. UNIFRAME secondary crusher phase I product characteristics . . . . . . . . . . . . 3-22

3-7. UNIFRAME secondary crusher phase I product characterization studies .................. 3-25

3-8. UNIFRAME tertiary crusher phase I tests . . . . . . . 3-30

3-9. UNIFRAME tertiary crusher phase I tests - product size distribution .................. 3-31 
3.10. UNIFRAME tertiary crusher 5512- $\mu$ m product size

distribution - phase I tests ........... 3-33

3-11. Summary of UNIFRAME oversize crusher phase I tests . . . 3-36

3-12. Lead angle comparisons from UNIFRAME screener

efficiency studies . . . . . . . . . . . . . 3-42

3-13. Screener blinding studies ............. 3-43

3-14. Screener self-cleaning studies . . . . . . . . . . 3-45

3-15. Screener tests with tertiary crusher product . . . . . . 3-47

3-16. Screener tests with tertiary crusher product . . . . . . 3-48

3-17. Screener test VC-38 with tertiary crusher product.... . 3-49

3-18. UNIFRAME screener phase I tests with half-size fuel ..... element, full-size fuel element, and half-size control rod element ............. 3- . . . . 52

3-19. UNIFRAME screener phase I tests (start-under-1oad) . . . . 3-54

4-1. Summary of phase II tests: primary, secondary, and

4-2. Tertiary crusher product size distributions: primary, secondary, and tertiary crusher shakedown, phase II tests .................. 4 4-4

4-3. Product distribution: phase II shakedown test SM-4 . . . 4-5

4-4. Summary of phase II shakedown tests . . . . . . . . . 4-5

4-5. Material balance: phase II tests . . . . . . . . . 4-9

4-6. Crushing times: phase II tests ............ 4-11

4-7. Product distributions: phase II tests ......... . 4-13

4-8. Screener product size distributions: phase II tests . . . 4-17

4-9. Replicate screen analysis of screener product from
phase II test UE-48 . . . . . . . . . . . . 4-19

4-10. Screener product size distributions (cumulative

4-11. Oversize crusher product size distributions:

4-12. Replicate screen analysis of oversize crusher product from test UE-48: phase II tests . . . . . . . . . . 4-25

4-13. Oversize crusher product size distributions
(cumulative wt $\%$ ): phase II tests ......... 4-27

4-14. Composite screener and oversize crusher product size distributions: phase II tests . . . . . . . . 4-29

4-15. Composite screener and oversize crusher product
size distributions (cumulative wt \%): phase II tests . . . 4-32 
4-16. Screener and oversize crusher product size distributions with $17 \%$ fuel particles $(<850 \mu \mathrm{m})$ added: phase II tests . . 4-37

5-1. Screener product size distributions: anode butt scrap graphite . . . . . . . . . . . . . . 5-2

5-2. Oversize crusher product size distributions: anode butt scrap graphite .. . . . . . . . . . . 5-3

5-3. Comparison of crushing behavior of HTGR fuel elements and scrap anode butt graphite ... . . . . . . . 5-7

5-4. Product size distributions: anode butt scrap graphite screener product transported and blended with oversize crusher product . . . . . . . . . . 5-10

5-5. Material balance, UNIFRAME scrap anode butt graphite crushing, tests SCRAP-1 through SCRAP-9 ........ . 5-13

5-6. UNIFRAME product pneumatic transport with intermittent oversize crusher operation . . . . . . . . . 5-16

5-7. Product size distributions: anode butt scrap graphite screener and oversize crusher product transport . . . . . 5-17

5-8. Material balance, UNIFRAME scrap anode butt graphite crushing, tests SCRAP-10 through SCRAP-18......... 5-20

5-9. Material balance results from scrap graphite crushing . . . 5-25

6-1. Material balance: phase III tests ........... 6-5

6-2. Product distribution ............. 6-6

6-3. Screener product - phase III tests - fueled HTGR elements................ . 6 6-8

6-4. Screener products - phase II tests - unfueled HTGR elements . . . . . . . . . . . . . . . 6-10

6-5. Oversize crusher product - phase III tests - fueled HTGR elements ............. . 6- 6-14

6-6. Oversize crusher products - phase II tests - unfueled HTGR elements ............... 6-16

6-7. Composite screener and oversize crusher products size distribution - phase III tests - fuel-loaded elements . . . 6-22

6-8. Composite screener and oversize crusher products size distribution - phase II tests - unloaded elements . . . . . 6-24

6-9. Particle breakage analysis: test UL-64, LHTGR H-451 graphite TRISO/BISO fuel element . . . . . . . . . 6-31

6-10. Particle breakage analysis FSV H-357 graphite -

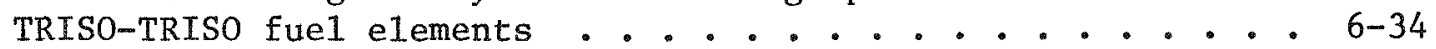

7-1. Summary of data from fuel element size reduction for sequential pilot plant operations .......... . 7-4 


\section{INTRODUCTION}

Genera1 Atomic Company (GA), under the direction of the Department of Energy (DOE), has the responsibility for developing a cold pilot plant for a high-temperature gas-cooled reactor (HTGR) fuel reference reprocessing facility (HRRF). Part of this responsibility is the development of a fuel element size reduction system.

The entire pilot plant process consists of (1) crushing the fuel elements to a size suitable for fluidized bed burning to remove graphite; (2) separating, crushing, and reburning the fissile and fertile particles to remove the majority of the remaining graphite; (3) dissolving and separating the particles from insoluble materials; and (4) performing solvent extraction to separate the uranium and thorium.

The fuel element crushing process is accomplished using a three-stage crushing system consisting of two overhead eccentric jaw crushers, a double-roll crusher, and an oversize reduction system (product monitor, screener separator, and oversize crusher) to ensure complete reduction of the elements to a size suitable for fluidized bed buming. The major equipment of the crushing system is mounted in a specially designed framework which replaces the jaw and roll crusher standard machine frames in an array utilizing gravity flow. This array eliminates the requirement for material transport devices and minimizes material holdup. The entire system has been designated UNIFRAME because of the integration of all the equipment into this specially designed structure.

This report describes the experimental work conducted to date with the UNIFRAME fuel element size reduction system. This work demonstrates the degree to which the design and operational capabilities required by the 
design criteria (see Appendix) have been met and evaluates the characteristics of the system. The objectives of this study, were as follows:

1. To demonstrate the system's capability to accept whole, partial, broken, or damaged standard HTGR fuel and control rod elements and reduce them to $54750-\mu \mathrm{m}$ ring-size particles having a size distribution suitable for use as a feed to the primary burner.

2. To demonstrate the system's capability to process fuel elements at a rate of one per fifteen minutes and twelve per day.

3. To evaluate material flow concepts.

4. To evaluate confinement of materials to desired flow paths.

5. To evaluate confinement of dusts.

6. To demonstrate the components' capability to start under 10 ad.

7. To evaluate the capability of the instrumentation to monitor and control crushing.

8. To demonstrate remote operation concepts.

9. To demonstrate the interchangeability of parts.

10. To demonstrate the design and operational capabilities of major equipment items and subsystems.

11. To demonstrate minimum $(\leq 5 \%)$ particle breakage.

12. To demonstrate certain semiremote operational and maintenance concepts. 
The test programs for the UNIFRAME system were divided into three phases to carry out these objectives:

Phase I: demonstration of the capabilities of each equipment item and its interaction with the subsystems.

Phase II: demonstration of the capabilities of the system and its interaction with the subsystems.

Phase III: demonstration of fuel-loaded element crushing and determination of the extent fuel particle breakage.

In addition to the tests planned for verifying the design criterion, some scrap graphite was crushed to use as feed for the primary burning investigation. This crushing provided opportunities for obtaining run and reliability data. The majority of the scrap graphite crushing was done between phases II and III. At the conclusion of phase III, twenty fueled elements were crushed as part of a pilot plant sequential operation demonstration.

1.1. PHASE I: DEMONSTRATION OF MAJOR EQUIPMENT ITEM CAPABILITIES AND THEIR INTERACTION WITH SUBSYSTEMS

The major objective of phase I was to demonstrate the degree to which each major equipment item met the requirements of the design criterion. Whole and half fuel elements and half control rod elements were used as feed to obtain information on the fuel element types and configurations. Products from each equipment item test were kept separate for the subsequent equipment item test. Because of the extensive amount of material crushed in phase $I$, no fuel particles were used. The tests consisted basically of the experiments outlined in Table 1-1 plus additional tests to correct problem areas. 
TABLE 1-1

EXPERTMENTS FOR PHASE I TESTS

\begin{tabular}{|c|c|c|}
\hline Equipment & $\begin{array}{l}\text { No. of } \\
\text { Tests }\end{array}$ & Feed Materia 1 \\
\hline Primary crusher & 3 & Half fuel element without fuel particles \\
\hline Primary crusher & 3 & $\begin{array}{l}\text { Half control rod element without fuel } \\
\text { particles }\end{array}$ \\
\hline Primary crusher & 3 & Whole fuel element without fuel particles \\
\hline Primary crusher & 3 & $\begin{array}{l}\text { Half fuel element without fuel } \\
\text { particles }\end{array}$ \\
\hline Secondary crusher & 12 & Materials from primary crusher tests \\
\hline Tertiary crusher & 12 & Materials from secondary crusher tests \\
\hline Vibratory screener & 6 & Materials from tertiary crusher tests \\
\hline Oversize pulverizer & 3 & $\begin{array}{l}\text { Crushed material: } 5.7 \mathrm{~kg}(+4750 \mu \mathrm{m})+ \\
5.7 \mathrm{~kg}(-4750 \mu \mathrm{m})\end{array}$ \\
\hline
\end{tabular}

1.2. PHASE II: DERONSTRATION OF UNIFRAME SYSTEM CAPABILITIES AND ITS INTERACTION WITH SUBSYSTEMS

The major objective of phase II testing was to demonstrate the degree to which the design and operational capabilities of the UNIFRAME as a system met the requirements of the design criterion. The tests consisted of the experiments outlined in Table 1-2.

TABLE 1-2

EXPERIMENTS FOR PHASE II TESTS

\begin{tabular}{c|c|c}
\hline Equipment & $\begin{array}{c}\text { No. of } \\
\text { Tests }\end{array}$ & \multicolumn{1}{c}{ Feed Material } \\
UNI FRAME & 3 & $\begin{array}{l}\text { Half fuel element without fuel particles } \\
\text { Half control rod element without fuel } \\
\text { particles } \\
\text { Whole fuel element without fuel particles }\end{array}$ \\
\hline
\end{tabular}




\subsection{PHASE III: DEMONSTRATION OF FUEL-LOADED ELEMENT CRUSHING AND FUEL PARTICLE BREAKAGE DETERMINATION}

The major objectives of phase III were to demonstrate the degree to which the UNIFRAME system met the requirements of the design criterion while crushing fuel-1oaded elements and to determine the extent of fuel particle breakage. The tests consisted of the experiments outlined in Table 1-3.

TABLE $1-3$

EXPERIMENTS FOR PHASE III TESTS

\begin{tabular}{l|c|c}
\hline Equipment & $\begin{array}{c}\text { No. of } \\
\text { Tests }\end{array}$ & Feed Material \\
\hline UNIFRAME & 3 & Whole fuel element with fuel particles (Fort St. Vrain) \\
UNIFRAME & 3 & Whole fuel element with fuel particles (large HTGR) \\
UNIFRAME & 1 & Whole control rod element with fuel particles \\
\hline
\end{tabular}




\section{EQUIPMENT DESCRIPTION}

The UNIFRAlE fuel element size reduction system comprises the following components:

1. Primary crusher.

2. Secondary crusher.

3. Tertiary crusher.

4. Oversize monitoring system.

5. Ventilation enclosure.

6. Drive system.

7. Structural machine frame.

8. Remote fixtures.

These components are briefly described below. A more detailed description can be found in Ref. 2-1. The arrangement of the major components is shown in Fig. 2-1.

\subsection{PRIMARY CRUSHER}

The primary crusher is an overhead eccentric jaw crusher which consists of two major assemblies: the pitman and the stationary jaw. The fuel elements are crushed to $<0.15-\mathrm{m}$ ring-size fragments between the wear plates by a motion induced by a rotating eccentric shaft and the toggle assembly. The toggle assembly has vertical members to facilitate proper ventilation and assure minimal material holdup. Large adjusting screws are used to adjust the angle of the stationary jaw.

\subsection{SECONDARY CRUSHER}

The secondary crusher is also an overhead eccentric jaw crusher. The primary crusher product discharges into the secondary crushing cavity and 


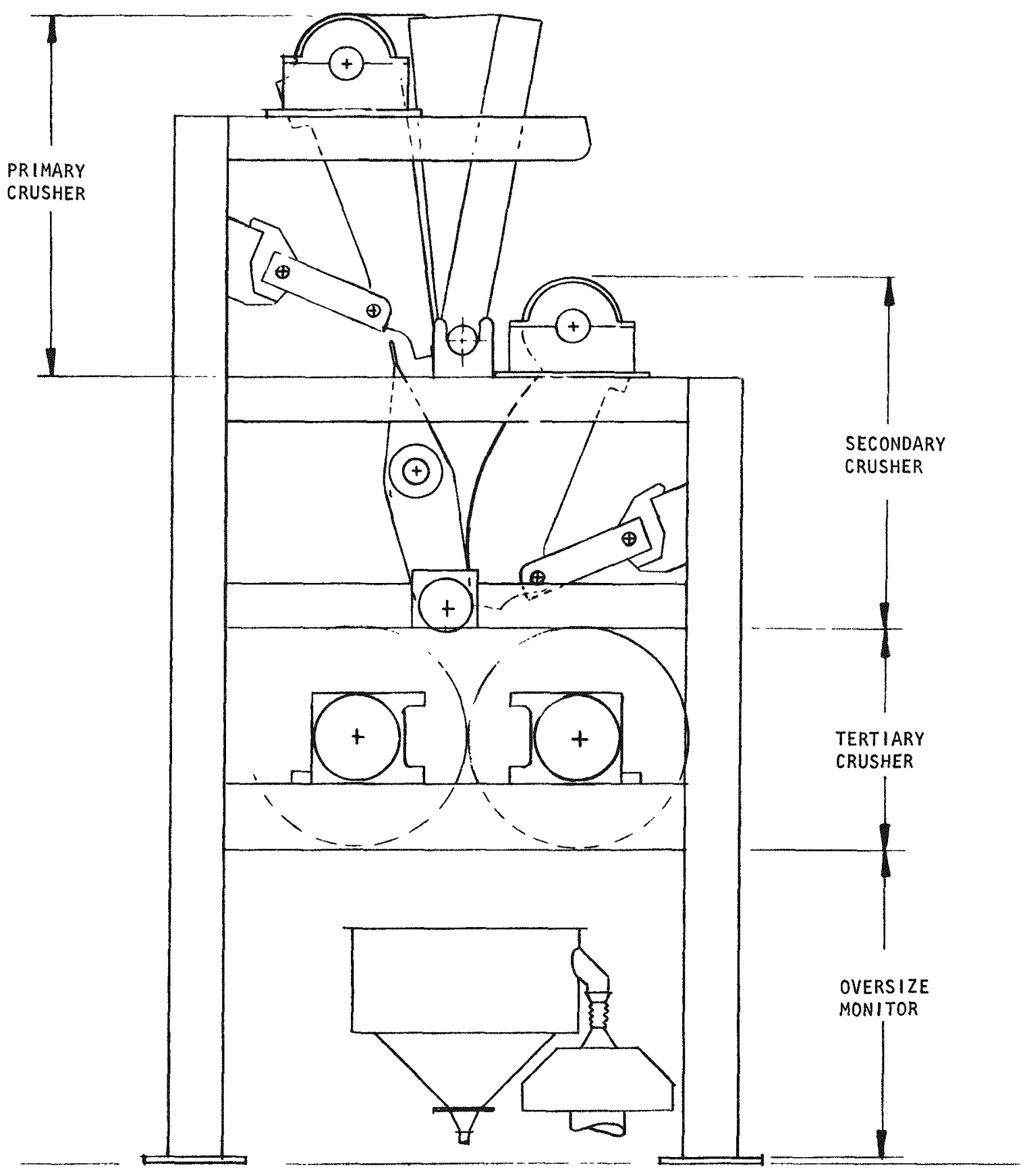

Fig. 2-1. UNIFRAME size reduction system (1ess drives and enclosures) 
is further reduced to $<0.05-\mathrm{m}$ fragments by crushing between the wear plates; side cheek plates are attached to the machine frame. The crushed product discharges by gravity to the tertiary crusher for the final size reduction stage. The secondary crusher toggle assembly is identical to that of the primary crusher, and both are secured to the machine frame by two locking bolts and nuts.

\subsection{TERTIARY CRUSHER}

The tertiary crusher is a double-roll crusher which consists of two major assemblies: the double-roll assembly and a structural support frame. The secondary crusher product discharges into the tertiary crusher and is reduced to $\leq 4750-\mu \mathrm{m}$ ring-size material by crushing between the rotating roll surfaces. The tertiary crusher product discharges into the oversize monitoring system. Material discharges from the tertiary crusher roll in a long, narrow band which, for maximum screener efficiency, must be redirected and concentrated into a centered position above the screener. This is accomplished by tertiary side chutes which are stepped and louvered to permit ventilation.

\subsection{OVERSIZE MONITORING SYSTEM}

The oversize monitoring system consists of a screener and an oversize crusher. This system forms a process safeguard which prevents oversize product from leaving the UNIFRAME system. Oversize product is separated by the vibratory screener and further reduced to an acceptable size by the oversize crusher. The outer housing of the screener forms a part of the UNIFRAME ventilation system and is a feed hopper to the pneumatic transport system. The screen is a square aperture with $4.75-\mathrm{mm}$ openings. The screener can be isolated from the rest of the UNIFRAME by a crusher shroud shutoff valve which allows the screener to be removed without spillage. 


\subsection{VENTILATION ENCLOSURE}

The ventilation system ensures that all product materials are contained within the UNIFRAME system. All components are enclosed to minimize material holdup and confine airborne products. Horizontal surfaces have been minimized, and areas which could contribute to material holdup have been eliminated, reduced, or shrouded.

\subsection{DRIVE SYSTEM}

The primary, secondary, and tertiary crushers are driven by electric motors mounted on a common framework which is isolated from the UNIFRAME structure and connected to the equipment by gear reducers and rubber belts. The oversize crusher drive is fixed to its separate base, and the screener drive is an integral part of the screener configuration. Each processing component has an independent drive system with separate controls.

\subsection{STRUCTURAL MACHINE FRAME}

The machine frame is a structural machined weldment designed to support the UNIFRAIIE components, to position the components with respect to each othex, and to confine the size reduction process within the frame. The four supporting colums are rigidly fixed to and mounted on an isolated concrete foundation.

\subsection{REMOTE FIXTURES}

A number of lift fixtures are available to demonstrate the remote features of the UNIFRAME. See Ref. $2-2$ for a description of these fixtures.

\subsection{REFERENCES}

2-1. Strand, J. B., J. W. Baer, and E. J. Cook, "UNIFRAME Interim Design Report," ERDA Report GA-A14645, General Atomic Company, December 1977. 
2-2. Ballard, A. S., "Interim Design status and Operational Report for Semi remote Handling Fixtures: Size Reduction System," ERDA Report GA-A14126, General Atomic Company, February 1977. 


\section{PHASE I TESTS}

\subsection{INTRODUCTION}

Phase I consisted of individual tests of the major equipment items in the fuel element size reduction system (UNIFRAME). Parametric studies on the primary crusher utilizing scrap unfueled fuel elements as feed led to the selection of the proper nip angle and close side settings (CSS). The product characteristics and operational capabilities of the primary crusher were determined by a series of crushing tests on unfueled full- and halfsize II-327 graphite fuel elements and a half-size control rod element. Crushed materials from the primary crusher tests were used for determining the product characteristics and operational capabilities of the secondary crusher. The differences in the products from the various element types and configurations, product size distributions, and material throughput rates were determined for both crushers. Checkout of lift fixtures for the primary and secondary crusher pitman assemblies and the primary stationary jaw was completed as part of the demonstration of remote maintenance capabilities.

\subsection{PRIMARY CRUSHER TESTS}

During preoperational assembly and checkout, it was found that the $5-\mathrm{cm}$ CSS specified in the design for the primary crusher had not been attained and the actual CSS was $\sim 3 \mathrm{~cm}$. Toggles measuring $41 \mathrm{~cm}$ were ordered to replace the original $46 \mathrm{~m} \mathrm{~cm}$ toggles. The smaller toggles, used with shims between the pushing block and the pushing beam, allowed flexibility in choice of CSS and permitted the CSS to be set to the desired $5 \mathrm{~cm}$. The discrepancy between the as-built cSS of $3 \mathrm{~cm}$ and the design CSS of $5 \mathrm{~cm}$ was investigated and determined to be the result of the accumulation of minor design and manufacturing variances and manufacturing 
tolerance buildup. The change from $46 m \mathrm{~cm}$ to $41-\mathrm{cm}$ toggles provided an opportunity for examining the solid, dry film lubricant system which had been applied to the toggle pin joints. The system used molybdenum disulfide $\left(\mathrm{MoS}_{2}\right)$ and antimony trioxide $\left(\mathrm{Sb}_{2} \mathrm{O}_{3}\right)$ with a polyimide binder and was applied only to the shaft surfaces.

After careful disassembly, both shafts and each bore were closely examined for evidence of wear or breakdown of the dry film lubricant. Since the investigation of the appearance of the bores and shaft surfaces was inconclusive, the lubricant system was stripped from half the diameter for the full length of the two shafts. The stripping was done by glass beads which were "soft" enough to remove the coating without damaging the substrate or destroying wear evidence. Figure 3-1 shows one shaft with the toggle positions identified. The upper portion of the shaft indicates the condition of the dry film lubricant after disassembly; the lower portion has been stripped of lubricant. The shiny, glazed-appearing areas are highly burnished regions of the coating. The less glossy regions are either lightly burnished or unscathed. Figure 3-2 is a close-up of the demarcation between the "as-rum" and the stripped dry film lubricant. This figure illustrates a typical condition of the underlying surfaces on both toggle shafts and clearly indicates that there is no wear damage to the steel substrate. The observations and comments of the dry film lubricant supplier are as follows:

"The coating, applied in accordance with MSFC 50M60434, appeared to have performed exceptionally well in preventing galling or spalling of the metal. The shiny black bands indicate areas where the contact loading was extremely high. This is exactly the film appearance found on McMillan (LFW-1) test races which have been run-in at loads up to $10,550 \mathrm{~kg} / \mathrm{cm}^{2}$.

The other 1ight grey areas on the shafts appeared to be scuffed from general handling, assembly, or disassembly. Again, there is nothing abnormal in appearance to be noted."

All bushing bores in the toggles, pushing block, and pitman casting showed evidence of varied degrees of transfer of the dry film lubricant 


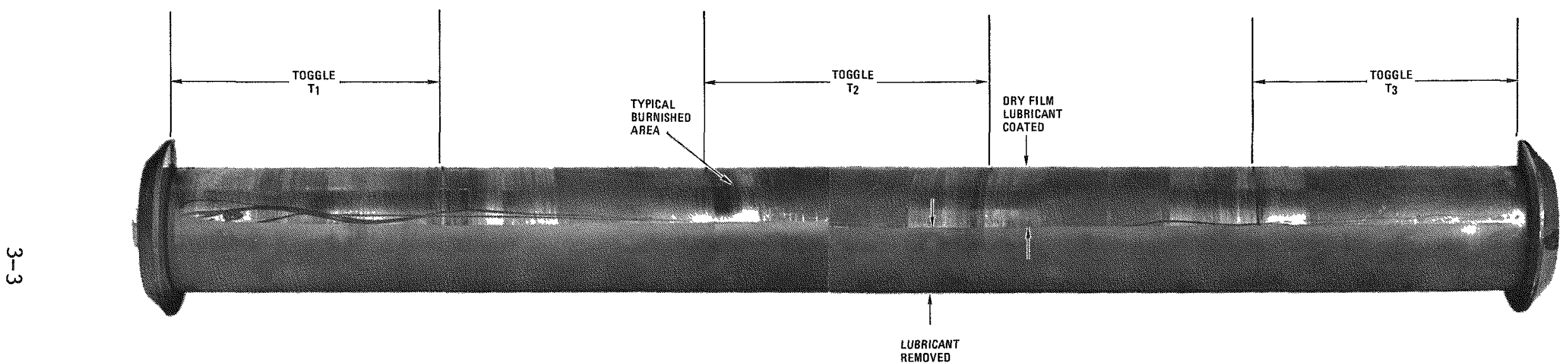

Fig. 3-1. Primary pitman toggle shaft (dry film lubricant removed from bottom half of shaft) 


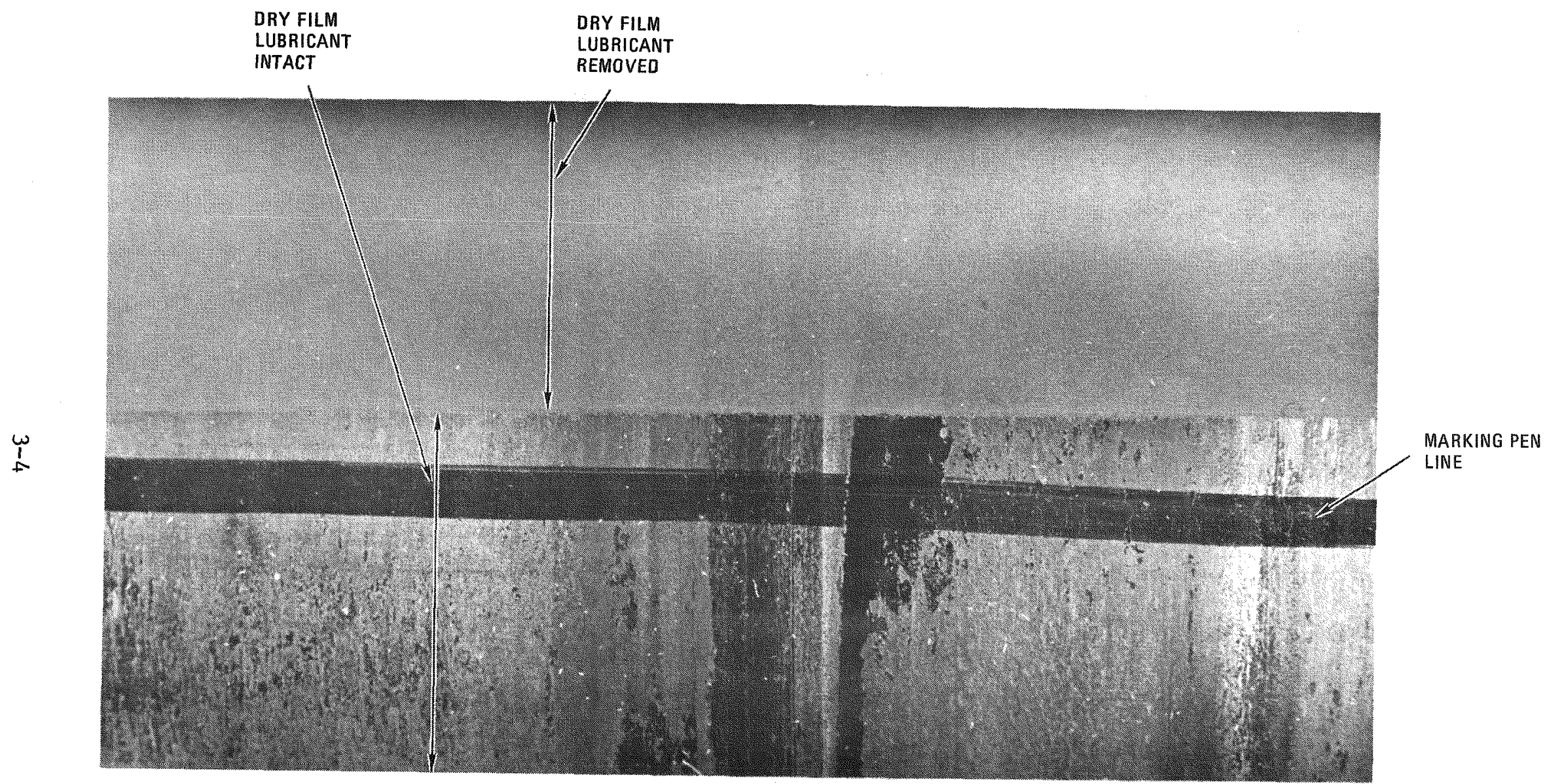

Fig. 3-2. Primary crusher toggle shaft showing absence of substrate damage 
from the shaft to the bores. Debris and wipings from each bore and shaft joumal have been collected and are available for analysis. Since there was no shaft wear, analysis has been deferred.

Initial checkout of the crusher was initiated with the $46-\mathrm{cm}$ toggles and the 3-cm CSS. A nip angle of $18 \mathrm{deg}$ was selected based on earlier experimental work (Ref. 3-1). Initial crushing using partial, unfueled blocks met with limited success. Parametric studies on the primary crusher were then undertaken to establish the proper nip angles and CSS for consistent crushing. Table 3-1 summarizes the results of these studies.

To permit adjustments of the primary crusher to a minimum nip angle of $13 \mathrm{deg}$, the height of the stationary jaw cheek plate assemblies had to be modified. In addition, a fuel element entry chute (Fig. 3-3) was fabricated and installed above the primary crusher. This unit was intended to eliminate the potential loss of material which might occur at initial crushing contact owing to the higher position of the fuel block resulting from the reduced nip angle. Figure 3-4 shows the primary stationary $j a w$ and the entry chute mounted in the maintenance fixture. The truncation of the cheek plates to reduce their height is evident.

Complete crushing occurred at nip angles of $14.5 \mathrm{deg}$ or less. Although all nip angles were not tested at each of the CSS, the results and observations of crushing behavior were consistent enough to conclude that this was the maximum nip angle that could be used at any of the CSS and still produce a reasonable probability for complete crushing of the fuel element. At nip angles above $14.5 \mathrm{deg}$, the fuel elements were only partially crushed. The remaining material merely slid up and down with the action of the pitman. A slight tendency for slippage was observed at the 14.5 - deg nip angle, but it was not pronounced enough to prevent the materials from being crushed. Instead, it resulted in longer time periods to complete the crushing. 
TABLE 3-1

UNIFRAME PRIMARY CRUSHER PHASE I PARAMETRIC STUDIES (a)

\begin{tabular}{|c|c|c|c|c|}
\hline Test & $\begin{array}{l}\text { Close Side } \\
\text { Setting } \\
{[\mathrm{cm} \text { (in.) }]}\end{array}$ & $\begin{array}{l}\text { Nip } \\
\text { Angle } \\
(\text { deg })\end{array}$ & Feed Material & Results \\
\hline $\mathrm{CP}-\mathrm{A}$ & $3.0(1.2)$ & 18 & $\begin{array}{l}\text { Full length segments of } \\
\text { standard fuel elements }\end{array}$ & Partial crushing \\
\hline $\mathrm{CP}-\mathrm{B}$ & $3.0(1.2)$ & 16 & $\begin{array}{l}\text { Uncrushed material from } \\
\text { previous test }(\mathrm{CP}-\mathrm{A})\end{array}$ & Partial crushing \\
\hline $\mathrm{CP}-\mathrm{C}$ & $3.0(1.2)$ & 18 & Standard fuel element & Partial crushing \\
\hline CP-D & $3.0(1.2)$ & 16 & $\begin{array}{l}\text { Uncrushed material from } \\
\text { previous test }(\mathrm{CP}-\mathrm{C})\end{array}$ & Partial crushing \\
\hline $\mathrm{CP}-\mathrm{E}$ & $5.3(2.1)$ & 18 & $1 / 2$ standard fuel element & $\begin{array}{l}\text { Partial crushing } \\
\text { (stalled crusher) }\end{array}$ \\
\hline $\mathrm{CP}-\mathrm{F}$ & $5.3(2.1)$ & 16 & $\begin{array}{l}\text { Uncrushed material from } \\
\text { previous test }(C P-E)\end{array}$ & Partial crushing \\
\hline $\mathrm{CP}-\mathrm{G}$ & $9.7(3.8)$ & 17 & $\begin{array}{l}\text { Uncrushed material from } \\
\text { previous test }(\mathrm{CP}-\mathrm{F})\end{array}$ & Partial crushing \\
\hline $\mathrm{CP}-\mathrm{H}$ & $9.7(3.8)$ & 13 & $\begin{array}{l}\text { Uncrushed material from } \\
\text { previous test }(C P-G)\end{array}$ & $\begin{array}{l}\text { Complete crushing } \\
\text { (as charged) }\end{array}$ \\
\hline $\mathrm{CP}-\mathrm{I}$ & $9.7(3.8)$ & 13 & $1 / 3$ standard fuel element & $\begin{array}{l}\text { Complete crushing } \\
(9 \mathrm{sec})\end{array}$ \\
\hline $\mathrm{CP}-\mathrm{J}$ & $9.7(3.8)$ & 15 & $\begin{array}{l}\text { Uncrushed material from } \\
\text { previous test }(\mathrm{CP}-\mathrm{D}) \\
(20.4 \mathrm{~kg})\end{array}$ & Partial crushing \\
\hline $\mathrm{CP}-\mathrm{K}$ & $9.7(3.8)$ & 14 & $\begin{array}{l}\text { Uncrushed material from } \\
\text { previous test }(\mathrm{CP}-\mathrm{J}) \\
(20.4 \mathrm{~kg})\end{array}$ & $\begin{array}{l}\text { Complete crushing } \\
(7.5 \mathrm{sec})\end{array}$ \\
\hline $\mathrm{CP}-\mathrm{L}$ & $5.3(2.1)$ & 14 & $\begin{array}{l}1 / 2 \text { standard fuel element } \\
\text { cut vertically }(39.7 \mathrm{~kg})\end{array}$ & $\begin{array}{l}\text { Complete crushing } \\
(19.5 \mathrm{sec})\end{array}$ \\
\hline $\mathrm{CP}-\mathrm{M}$ & $5.3(2.1)$ & 14.5 & $\begin{array}{l}1 / 2 \text { standard fuel element } \\
\text { cut horizontally; no } \\
\text { coolant holes, partial fuel } \\
\text { holes }(70.3 \mathrm{~kg})\end{array}$ & $\begin{array}{l}\text { Complete crushing } \\
\text { ( } 6 \text { min } 15 \mathrm{sec})\end{array}$ \\
\hline $\mathrm{CP}-\mathrm{N}$ & $5.3(2.1)$ & 14.5 & $\begin{array}{l}1 / 2 \text { standard fuel element } \\
\text { cut horizontally; no fuel } \\
\text { holes, complete coolant } \\
\text { holes }(61.2 \mathrm{~kg})\end{array}$ & $\begin{array}{l}\text { Complete crushing } \\
(5 \mathrm{~min} 45 \mathrm{sec})\end{array}$ \\
\hline
\end{tabular}


TABLE 3-1 (Continued)

\begin{tabular}{|c|c|c|c|c|}
\hline Test & $\begin{array}{l}\text { Close Side } \\
\text { Setting } \\
{[\mathrm{cm}(\text { in.) }]}\end{array}$ & $\begin{array}{l}\text { Nip } \\
\text { Angle (b) }\end{array}$ & Feed Material & Results \\
\hline $\mathrm{CP}-\mathrm{O}$ & $5.3(2.1)$ & 14.5 & $\begin{array}{l}\text { Standard fuel element; last } \\
\text { two rows of fuel holes } \\
\text { removed by vertical cut } \\
(83.0 \mathrm{~kg})\end{array}$ & $\begin{array}{l}\text { Complete crushing } \\
(4 \mathrm{~min} 5 \mathrm{sec})\end{array}$ \\
\hline $\mathrm{CP}-\mathrm{P}$ & $5.3(2.1)$ & 14.5 & $\begin{array}{l}\text { Standard fuel element; last } \\
\text { five rows of fuel holes } \\
\text { removed by vertical cut } \\
(73.5 \mathrm{~kg})\end{array}$ & $\begin{array}{l}\text { Complete crushing } \\
(3 \mathrm{~min} 5 \mathrm{sec})\end{array}$ \\
\hline
\end{tabular}
(a) Crusher speed $=200 \mathrm{rpm}$.
(b) Measured at the close side setting. 


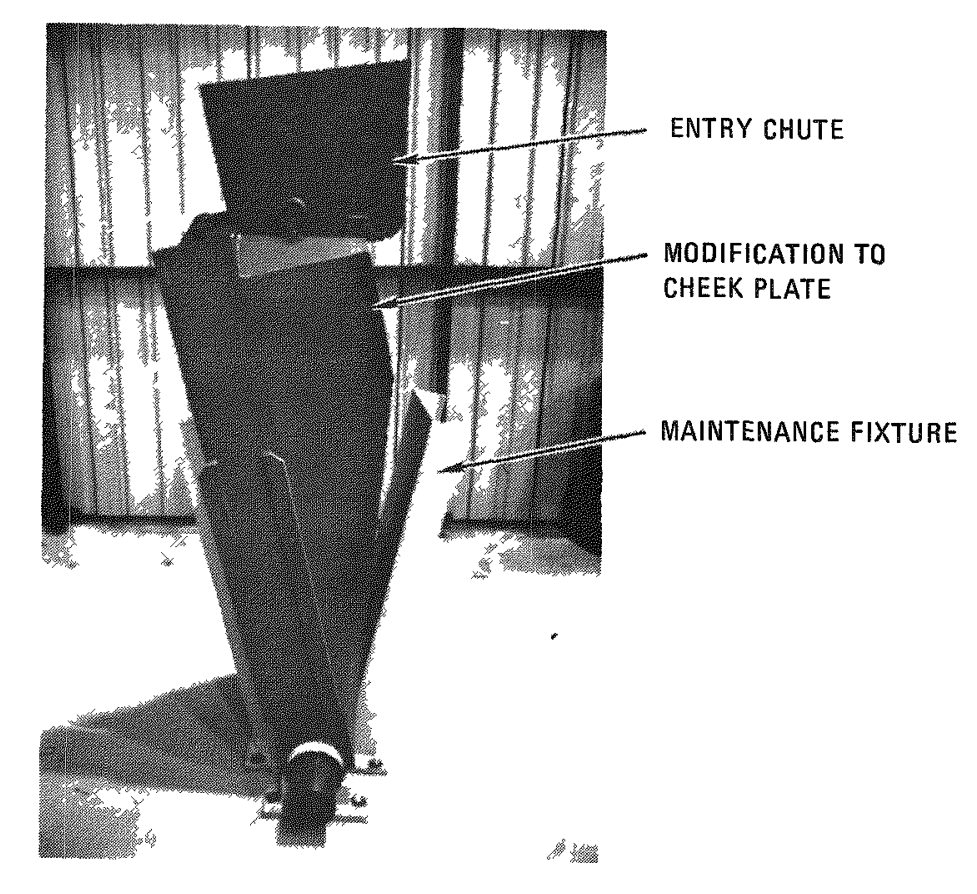

Fig. 3-3. Primary crusher stationary jaw showing modifications and entry chute

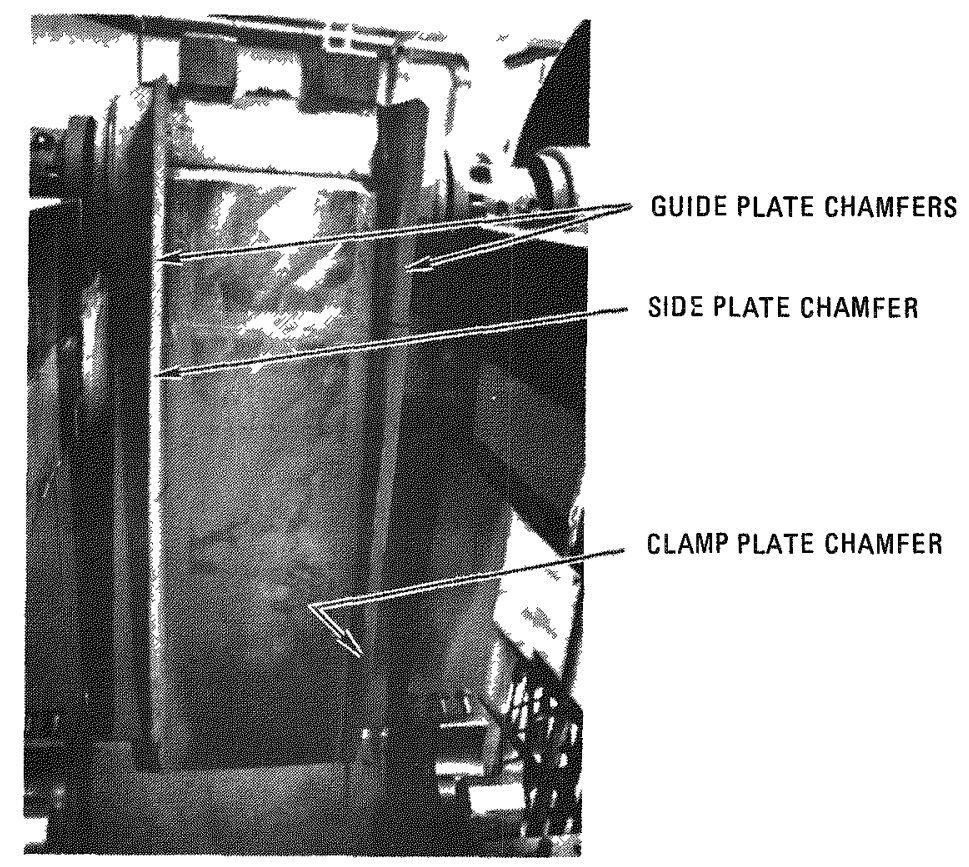

Fig. 3-4. Primary pitman assembly showing chamfered side plates 
The results of these studies led to the selection of a $5-\mathrm{cm}$ CSS and a 14-deg nip angle as the parameters for subsequent tests demonstrating the primary crusher product characteristics. A $5-\mathrm{cm}$ CSS was selected because it was expected to yield a crushed product sufficiently reduced in size to be acceptable for secondary crusher feed. The 14-deg nip angle was selected because it provided a combination of a high probability for complete crushing with an acceptable crusher gape (feed opening).

Using these settings, three unfueled full-size H-327 graphite fuel elements, three unfueled half-size $\mathrm{H}-327$ fuel elements, and one half-size H-327 control rod element were separately crushed and their products collected to study the primary crusher product characteristics. The unfueled half-size $\mathrm{H}-327$ fuel elements provided a comparison with the unfueled full-size $\mathrm{H}-327$ fuel elements to indicate if significant crushed product differences could be expected from the processing of whole, partial, broken, or damaged fuel elements. The unfueled half-size $\mathrm{H}-327$ control rod element provided a comparison with the unfueled half-size $\mathrm{H}-327$ fuel element to indicate if significant crushed product differences could be expected from the processing of different types of elements. Table 3-2 summarizes the results of these tests.

In one of the tests $(\mathrm{PC}-3 \mathrm{~A})$, the element fractured along the fuel and coolant hole planes in a pattern which allowed the crushing force to wedge the fragments between the two side plates of the pitman assembly. The material thus captured moved with the action of the pitman without sliding up or down or falling further into the crushing cavity. Contact of the captured materials with the stationary jaw wear surface was of insufficient force to produce further crushing. This phenomenon was unrelated to the conditions of slippage which occurred at nip angles greater than 14.5 deg; this slippage was caused by the vertical crushing forces exceeding the frictional forces. The adjustable stationary jaw was moved to a smaller nip angle, providing recontact of the material with both crushing surfaces, and crushing was reinstituted to completion. This procedure for clearing a 
TABLE 3-2

UNIFRAME PRIMARY CRUSHER PHASE I PRODUCT CHARACTERISTICS

Crusher Speed $=200 \mathrm{rpm} ;$ Close Side Setting $=5.3 \mathrm{~cm}(2.1 \mathrm{in.})$;

Nip Angle $=14^{\circ}$ measured at CSS

\begin{tabular}{|c|c|c|}
\hline Test & Feed Material & Resu1ts \\
\hline $\mathrm{PC}-1$ & $\begin{array}{l}\text { One-half of a standard } \mathrm{H}-327 \text { fuel } \\
\text { element, cut horizontally, } 39.2 \mathrm{~cm} \\
(15-7 / 16 \text { in.) 1ong, } 43.1 \mathrm{~kg}\end{array}$ & $\begin{array}{l}\text { Complete crushing } \\
(1 \min 2 \mathrm{sec})\end{array}$ \\
\hline $\mathrm{PC}-2$ & $\begin{array}{l}\text { One-half of a standard H-327 fuel } \\
\text { element, cut horizontally, } 39.4 \mathrm{~cm} \\
(15-1 / 2 \mathrm{in.}) \text { long, } 44.5 \mathrm{~kg}\end{array}$ & $\begin{array}{l}\text { Complete crushing } \\
(28 \mathrm{sec})\end{array}$ \\
\hline $\mathrm{PC}-3 \mathrm{~A}$ & $\begin{array}{l}\text { One-half of a standard } \mathrm{H}-327 \text { fuel } \\
\text { element, cut horizontally, } 40 \mathrm{~cm} \\
(15-3 / 4 \text { in.) long, } 45.4 \mathrm{~kg}\end{array}$ & $\begin{array}{l}\text { Complete crushing; abnormal } \\
\text { operating conditions imposed } \\
\text { due to jammed material }\end{array}$ \\
\hline$P C-3 B$ & $\begin{array}{l}\text { One-half of a standard } \mathrm{H}-327 \text { fuel } \\
\text { element, cut horizontally, } 39.8 \mathrm{~cm} \\
(15-11 / 16 \text { in.) long, } 44.2 \mathrm{~kg}\end{array}$ & $\begin{array}{l}\text { Complete crushing } \\
(24 \mathrm{sec})\end{array}$ \\
\hline$P C-4$ & $\begin{array}{l}\text { One-half of a H-327 control rod } \\
\text { element, cut horizontally, } 39.4 \mathrm{~cm} \\
(15-1 / 2 \text { in.) long, } 42.4 \mathrm{~kg}\end{array}$ & $\begin{array}{l}\text { Complete crushing } \\
(32 \mathrm{sec})\end{array}$ \\
\hline $\mathrm{PC}-7$ & $\begin{array}{l}\text { One whole standard } \mathrm{H}-327 \text { fuel } \\
\text { element, } 90.7 \mathrm{~kg}\end{array}$ & $\begin{array}{l}\text { Complete crushing } \\
(3 \mathrm{~min} 26 \mathrm{sec} \text { ) }\end{array}$ \\
\hline PC-8 & $\begin{array}{l}\text { One whole standard } \mathrm{H}-327 \text { fuel } \\
\text { element, } 89.4 \mathrm{~kg}\end{array}$ & $\begin{array}{l}\text { Complete crushing } \\
(1 \mathrm{~min} 28 \mathrm{sec})\end{array}$ \\
\hline PC-9 & $\begin{array}{l}\text { One whole standard } \mathrm{H}-327 \text { fuel } \\
\text { element, } 89.4 \mathrm{~kg}\end{array}$ & $\begin{array}{l}\text { Complete crushing } \\
\text { ( } 1 \mathrm{~min} 16 \mathrm{sec}\end{array}$ \\
\hline
\end{tabular}


similarly jammed element has been included in the operating procedures. To reduce the tendency to wedge or bridge, a design change was incorporated which put a 1.27 by $2.22 \mathrm{~cm}$ chamfer on the top interior edges of the guide plates, clamp plate, and side plate. These chamfers are shown in Fig. 3-4.

The test was repeated $(\mathrm{PC}-3 \mathrm{~B})$ because of the possibility that the crushed product from test PC-3A would have atypical size distribution characteristics owing to the abnormal operation. No further jamming occurred in the repeat test and all other tests, nor was a tendency to jam observed. Determination of primary crusher product characteristics from crushing of $\mathrm{H}-327$ control rod elements was limited to a single test because of the shortage of available control rod elements. Material throughput rates varied from $\sim 42$ to $\sim 111 \mathrm{~kg} / \mathrm{min}$ in the replicate tests on half-size fuel elements and from $\sim 26$ to $\sim 61 \mathrm{~kg} / \mathrm{min}$ in the replicate tests on fullsize fuel elements. The throughput rate for the single half-size control rod element was $\sim 79 \mathrm{~kg} / \mathrm{min}$. The large variability in throughputs for replicate tests and the overlapping rates between sizes and types of elements did not indicate any definite relationships between throughput and size or type of element. However, all the throughput rates were well above the requirement for processing an entire fuel element in less than 15 min. In all the tests, materials were totally confined to the crushing cavity, and no material holdup was detected.

The product size distributions from each test have been determined. The larger-size product was manually separated and passed through various ring-size openings in $2.54-\mathrm{cm}$ increments to determine the distribution of ring-size material from 2.55 to $15.2 \mathrm{~cm}$. Product smaller than $2.54-\mathrm{cm}$ ring size was separated by hand screening into plus and minus $0.475-\mathrm{cm}$ mesh fractions. The results of the product size characterizations are shown in Table 3-3.

The product size distributions resulting from the replicate tests on half-size and full-size fuel elements are shown in Figs. $3-5$ and 3-6, 
TABLE 3-3

UNIFRAME PRIMARY CRUSHER PRODUCT CHARACTERIZATION STUDIES

Close Side Setting $5.3 \mathrm{~cm}(2.1 \mathrm{in.})$; Nip Angle $=14^{\circ}$; Crusher Speed $=200 \mathrm{rpm}$

\begin{tabular}{|c|c|c|c|c|c|c|c|c|}
\hline \multicolumn{9}{|c|}{ Half-Size Fuel Element Tests } \\
\hline \multirow{2}{*}{$\begin{array}{l}\text { Ring Size } \\
{[\mathrm{cm}(\text { in.) }]}\end{array}$} & \multicolumn{2}{|c|}{$\mathrm{PC}-1$} & \multicolumn{2}{|c|}{$\mathrm{PC}-2$} & \multicolumn{2}{|r|}{$P C-3 B$} & \multicolumn{2}{|r|}{ Avg } \\
\hline & Wt \% & Cum. Wt \% & Wt \% & Cum. Wt & Wt \% & Cum. Wt \% & Wt \% & Cum. Wt \% \\
\hline$+15.4(+6)$ & 1.5 & 100.0 & 6.8 & 100.0 & 3.3 & 100.0 & 3.9 & 100.0 \\
\hline$-15.4(-6)+12.7(+5)$ & 0 & 98.5 & 2.3 & 93.2 & 8.4 & 96.7 & 3.6 & 96.1 \\
\hline$-12.7(-5)+10.2(+4)$ & 11.2 & 98.5 & 6.9 & 90.9 & 0.9 & 88.3 & 6.3 & 92.5 \\
\hline$-10.2(-4)+7.6(+3)$ & 10.6 & 87.3 & 14.2 & 84.0 & 14.1 & 87.4 & 13.0 & 86.2 \\
\hline$-7.6(-3)+5.1(+2)$ & 12.2 & 76.7 & 11.8 & 69.8 & 13.9 & 73.3 & 12.6 & 73.2 \\
\hline$-5.1(-2)+2.5(+1)$ & 17.9 & 64.5 & 19.4 & 58.0 & 15.4 & 59.4 & 17.6 & 60.6 \\
\hline$-2.5(-1)+0.48^{(a)}$ & 39.4 & 46.6 & 32.3 & 38.6 & 36.3 & 44.0 & 36.0 & 73.0 \\
\hline$-0.48^{(a)}$ & 7.2 & 7.2 & 6.3 & 6.3 & 7.7 & 7.7 & 7.0 & 7.0 \\
\hline \multicolumn{9}{|c|}{ Control Rod Element Tests } \\
\hline & \multirow{2}{*}{\multicolumn{3}{|c|}{$\begin{array}{l}\text { Ring Size } \\
{[\mathrm{cm} \text { (in.) }]}\end{array}$}} & \multicolumn{3}{|c|}{$\mathrm{PC}-4$} & & \\
\hline & & & & Wt \% & Cum. Wt & & & \\
\hline & \multicolumn{3}{|c|}{$+15.4(+6)$} & 25.6 & 100.0 & & & \\
\hline & \multicolumn{3}{|c|}{$-15.4(-6)+12.7(+5)$} & 4.6 & 74.4 & & & \\
\hline & \multicolumn{3}{|c|}{$-12.7(-5)+10.2(+4)$} & 9.6 & 69.8 & & & \\
\hline & \multicolumn{3}{|c|}{$-10.2(-4)+7.6(+3)$} & 16.6 & 60.2 & & & \\
\hline & \multicolumn{3}{|c|}{$-7.6(-3)+5.1(+2)$} & 12.2 & 43.6 & & & \\
\hline & & 10.5 & 31.4 & & & \\
\hline & \multicolumn{3}{|c|}{$-2.5(-1)+0.48^{(a)}$} & 17.7 & 20.9 & & & \\
\hline & \multicolumn{3}{|c|}{$-0.48^{(a)}$} & 3.2 & 3.2 & & & \\
\hline
\end{tabular}

Ful1-Size Fuel Element Tests

\begin{tabular}{r|r|r|r|r|r|r|r|r|}
\hline \multirow{2}{*}{$\begin{array}{c}\text { Ring Size } \\
{[\mathrm{cm}(\text { in. })]}\end{array}$} & \multicolumn{2}{|c|}{ PC-7 } & \multicolumn{2}{|c|}{ PC-8 } & \multicolumn{2}{c|}{ PC-9 } & \multicolumn{3}{c}{ Avg. } \\
\cline { 2 - 9 }$+15.4(+6)$ & 0 & 100.0 & 0 & 100.0 & 2.7 & 100.0 & 0.9 & 100.0 \\
\hline$-15.4(-6)+12.7(+5)$ & 1.6 & 100.0 & 1.0 & 100.0 & 0 & 97.3 & 0.9 & 99.1 \\
$-12.7(-5)+10.2(+4)$ & 6.8 & 98.4 & 7.6 & 99.0 & 8.0 & 97.3 & 7.4 & 98.2 \\
$-10.2(-4)+7.6(+3)$ & 11.7 & 91.6 & 8.2 & 91.4 & 14.6 & 89.3 & 11.5 & 90.8 \\
$-7.6(-3)+5.1(+2)$ & 13.8 & 79.9 & 15.0 & 83.2 & 11.0 & 74.7 & 13.3 & 79.3 \\
$-5.1(-2)+2.5(+1)$ & 16.8 & 66.1 & 17.9 & 68.2 & 16.1 & 63.7 & 16.9 & 66.0 \\
$-2.5(-1)+0.48(a)$ & 39.5 & 49.3 & 40.9 & 50.3 & 38.3 & 47.6 & 39.6 & 49.1 \\
$-0.48(a)$ & 9.8 & 9.8 & 9.4 & 9.4 & 9.3 & 9.3 & 9.5 & 9.5 \\
\hline
\end{tabular}

(a) Screen size. 


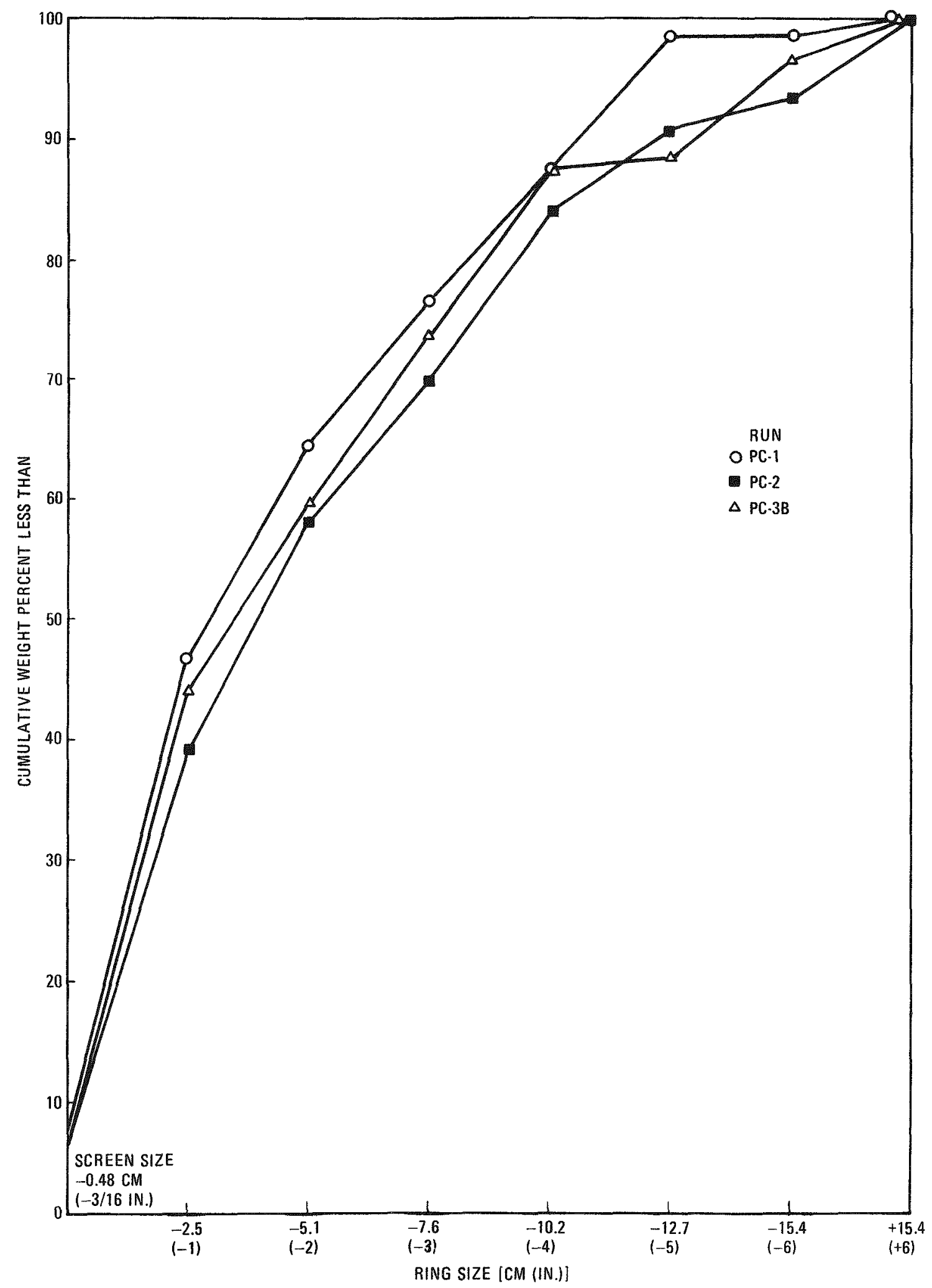

Fig. 3-5. Product size distributions in half-size H-327 fuel element tests 


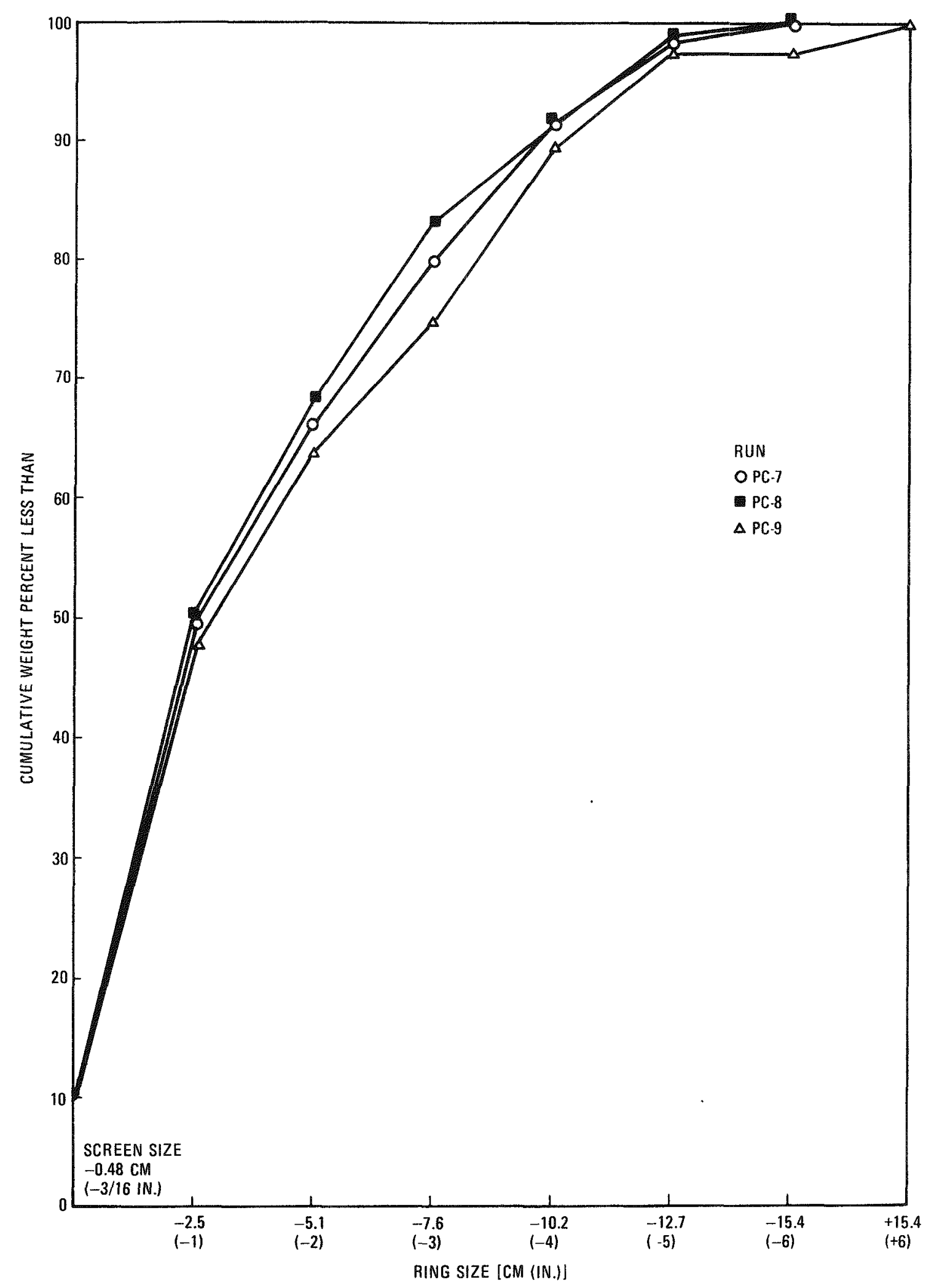

Fig. 3-6. Product size distributions in ful1-size H-327 fuel element tests 
respectively. These figures show that reasonably consistent products were obtained from the replicate crushing tests on each size fuel element, even at the larger ring-size fractions where a single piece could make a difference of several percent.

In general, the difference between the half-size and full-size fuel element three-run averages for each size fraction was insignificant. However, the product from the single test of primary crushing of a halfsize control rod element was larger (Figs. 3-7 and 3-8). Because of the large-diameter control rod holes and the smaller number of coolant and fuel holes, the fracture planes of the control rod element produced larger fragments. Product greater than $15.2-\mathrm{cm}$ ring size was measured to establish the nominal ring size; these data are given in Table 3-4. Material greater than $15.2-\mathrm{cm}$ nominal ring size was found in product from two of the runs: $\mathrm{PC}-4$, the half-size control rod element test, and PC-9, a full-size fuel element test. The quantity of fragments this size was small, $i_{\text {.e., three }}$ pieces in $\mathrm{PC}-4$ and one piece in PC-9. Typical material greater than 15.2-cm ring size is illustrated in Figs. 3-9 and 3-10. Portions of the control rod holes were present in all the $15.2-\mathrm{cm}$ ring-size material produced in the half-size control rod element test. Crushed products from the primary crusher tests were used as feed for phase I testing of the secondary crusher.

\subsection{SECONDARY CRUSHER TESTS}

\subsubsection{Test Activities}

Crushed materials from the primary crusher parametric tests were utilized for observing the operation of the secondary crusher prior to demonstrating its product characteristics (Table 3-5). Material produced with a $9.7-\mathrm{cm}$ CSS on the primary crusher failed to be completely crushed in the secondary crusher. The smaller fragments were readily crushed, but the larger fragments with all dimensions $>7.6 \mathrm{~cm}$ merely rode up and down with 


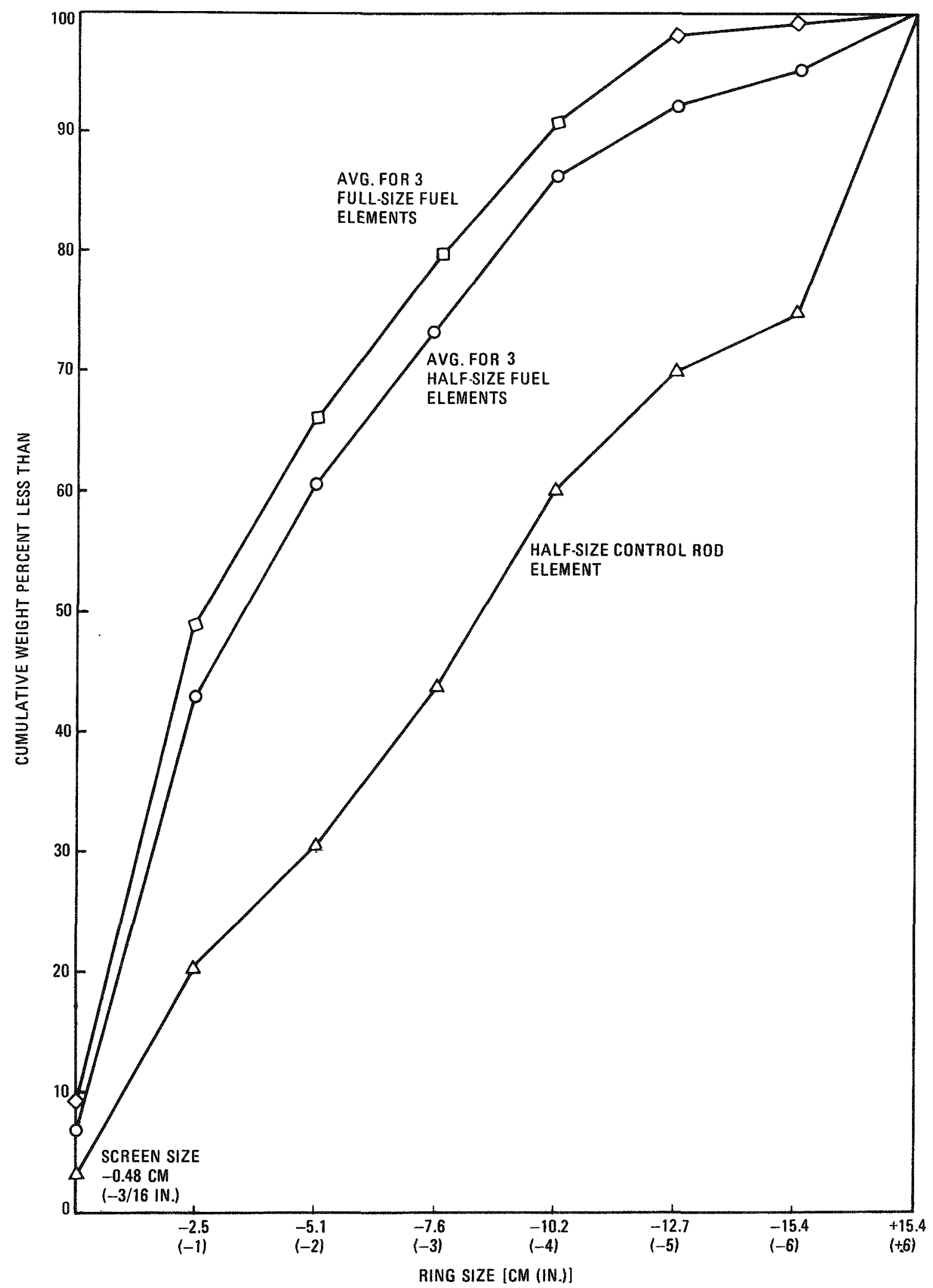

Fig. 3-7. Product size distributions in UNIFRAME primary crusher tests 

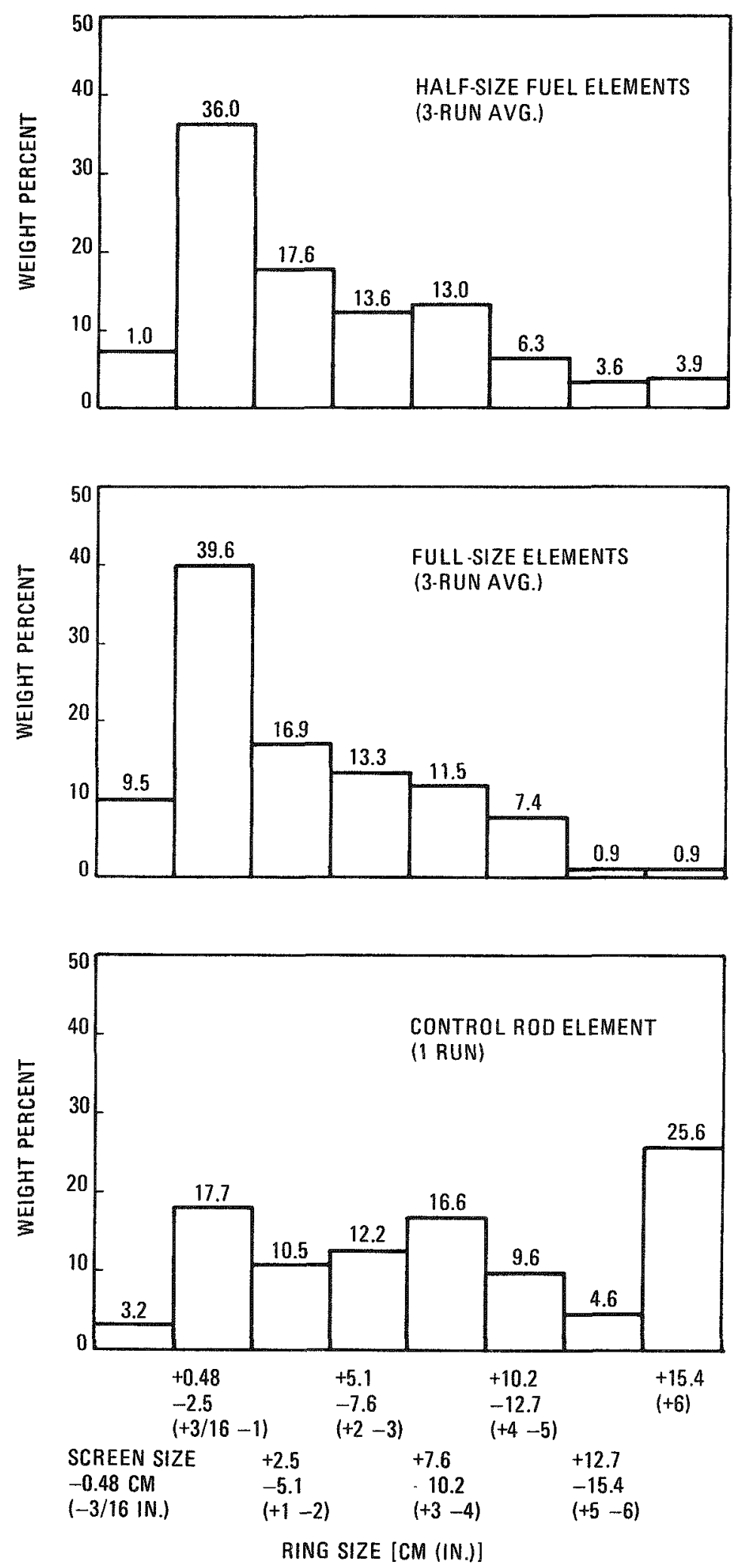

Fig. 3-8. Weight percent of each size fraction in UNIFRAME primary crusher tests 
TABLE $3-4$

UNIFRAME PRIMARY CRUSHER TESTS - CHARACTERISTICS OF MATERIAL GREATER THAN 15 CM (6 IN.) RING SIZE

\begin{tabular}{|c|c|c|c|c|c|}
\hline $\begin{array}{c}\text { Nominal Ring } \\
\text { Size } \\
{[\mathrm{cm} \text { (in.) }]}\end{array}$ & $\begin{array}{c}\text { Max. } \\
\text { Length } \\
{[\mathrm{cm} \text { (in.) }]}\end{array}$ & $\begin{array}{c}\text { Max. } \\
\text { Width } \\
{[\mathrm{cm}(\text { in. })]}\end{array}$ & $\begin{array}{l}\text { Max. } \\
\text { Thickness } \\
{[\mathrm{cm} \text { (in.) }]}\end{array}$ & $\begin{array}{l}\text { Weight } \\
(\mathrm{kg})\end{array}$ & $\begin{array}{l}\text { Wt \% of } \\
\text { Total Product }\end{array}$ \\
\hline \multicolumn{6}{|c|}{ Run $\mathrm{PC}-1$} \\
\hline $15(6)$ & $28(11)$ & $15.9(6-1 / 4)$ & $2.2(7 / 8)$ & 0.638 & 1.5 \\
\hline \multicolumn{6}{|c|}{ Run $\mathrm{PC}-2$} \\
\hline $\begin{array}{l}15(6) \\
15(6) \\
15(6)\end{array}$ & $\begin{array}{ll}28 & (11) \\
23 & (9) \\
20 & (8)\end{array}$ & $\begin{array}{ll}16.5 & (6-1 / 2) \\
16.5 & (6-1 / 2) \\
16.5 & (6-1 / 2)\end{array}$ & $\begin{array}{ll}2.9 & (1-1 / 8) \\
6.4 & (2-1 / 2) \\
5.1 & (2)\end{array}$ & $\begin{array}{l}1.044 \\
1.064 \\
0.919\end{array}$ & $\begin{array}{l}2.3 \\
2.4 \\
2.1\end{array}$ \\
\hline Total 5 & & & & 3.027 & 6.8 \\
\hline \multicolumn{6}{|c|}{ Run $P C-3 B$} \\
\hline $15(6)$ & $29(11-1 / 2)$ & $16.5(6-1 / 2)$ & $5.7(2-1 / 4)$ & 1.419 & 3.3 \\
\hline \multicolumn{6}{|c|}{ Run $P C-4$} \\
\hline $\begin{array}{l}20(8) \\
20(8)\end{array}$ & $\begin{array}{ll}39 & (15-1 / 2) \\
22 & (8-1 / 2)\end{array}$ & $\begin{array}{ll}21.0 & (8-1 / 4) \\
20.0 & (7-7 / 8)\end{array}$ & $\begin{array}{ll}7.0 & (2-3 / 4) \\
5.4 & (2-1 / 8)\end{array}$ & $\begin{array}{l}3.426 \\
1.793\end{array}$ & $\begin{array}{l}7.9 \\
4.2\end{array}$ \\
\hline Total 20 & & & & 5.219 & 12.1 \\
\hline $\begin{array}{l}18(7) \\
15(6) \\
15(6)\end{array}$ & $\begin{array}{ll}39 & (15-1 / 2) \\
26 & (10-1 / 4) \\
23 & (9-1 / 4)\end{array}$ & $\begin{array}{ll}18.1 & (7-1 / 8) \\
15.6 & (6-1 / 8) \\
15.9 & (6-1 / 4)\end{array}$ & $\begin{array}{ll}6.4 & (2-1 / 2) \\
6.4 & (2-1 / 2) \\
4.8 & (1-7 / 8)\end{array}$ & $\begin{array}{l}3.155 \\
1.463 \\
1.227\end{array}$ & $\begin{array}{l}7.3 \\
3.4 \\
2.8\end{array}$ \\
\hline Total 15 & & & & 2.690 & 25.6 \\
\hline Total Run & & & & 11.064 & 25.6 \\
\hline \multicolumn{6}{|c|}{ Run $\mathrm{PC}-7$} \\
\hline None & & & & & 0 \\
\hline \multicolumn{6}{|c|}{ Run $\mathrm{PC}-8$} \\
\hline None & & & & & 0 \\
\hline \multicolumn{6}{|c|}{ Run $\mathrm{PC}-9$} \\
\hline $18(7)$ & $20(8)$ & $17.8(7)$ & $7.0(2-3 / 4)$ & 1.285 & 2.7 \\
\hline
\end{tabular}




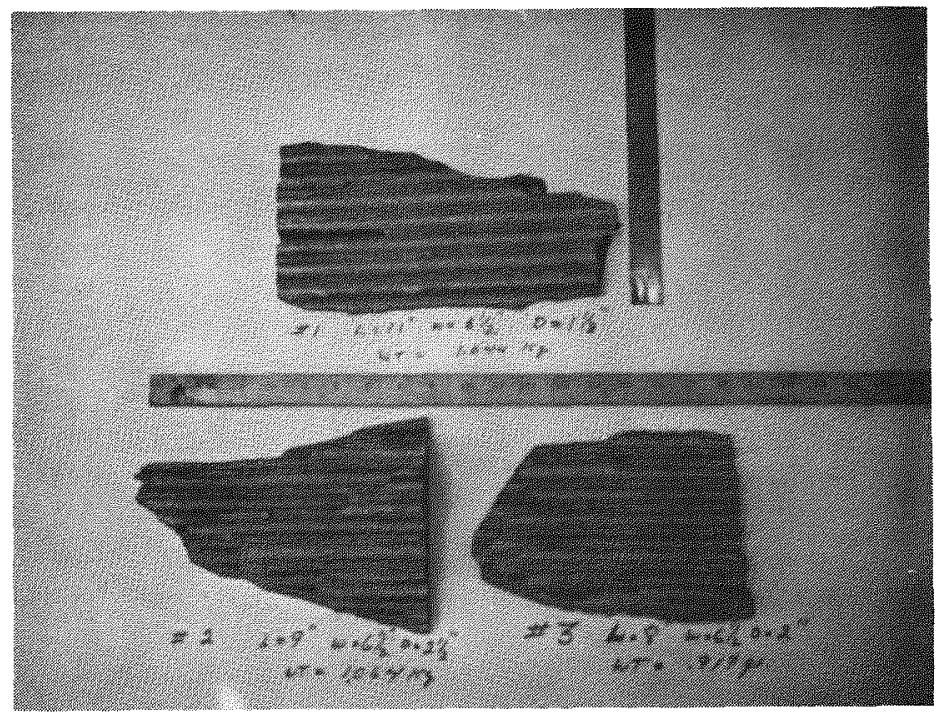

Fig. 3-9. $+15-\mathrm{cm}$ ring size material from test $\mathrm{PC}-2$ : primary crushing of an unfueled half-size $\mathrm{H}-327$ fuel element

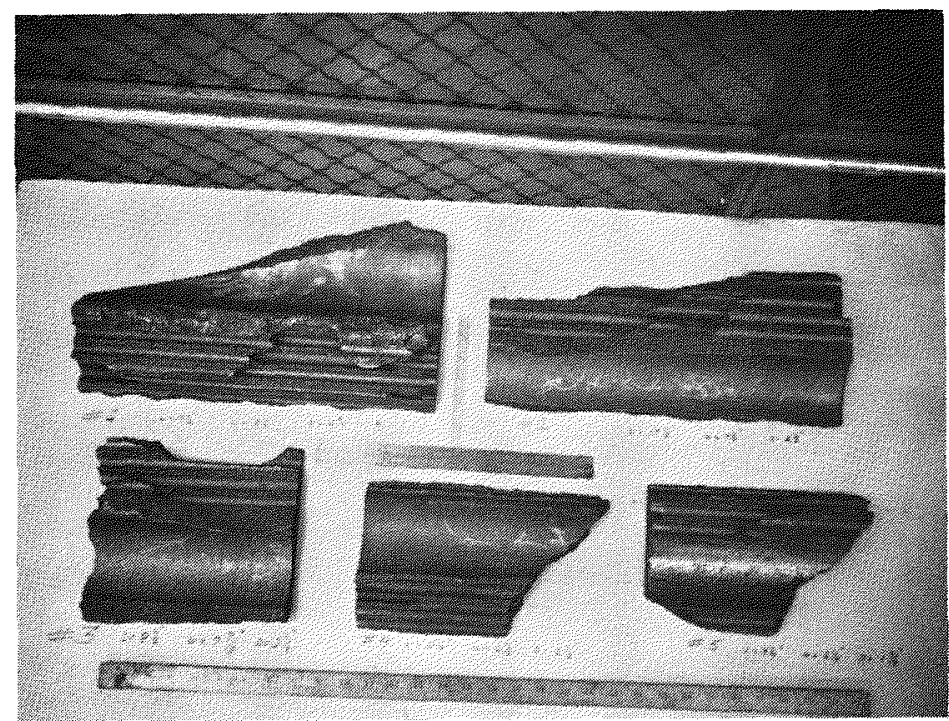

Fig. 3-10. $+15-\mathrm{cm}$ ring-size material from test $\mathrm{PC}-4$ : primary crushing of an unfueled half-size $\mathrm{H}-327$ control rod element 
TABLE 3-5

UNIFRAME SECONDARY CRUSHER OPERATION TESTS ${ }^{(a)}$

\begin{tabular}{|c|c|c|}
\hline Test & Feed Material & Result \\
\hline SP-A & $\begin{array}{l}\text { From primary crusher test } \mathrm{CP}-\mathrm{H} \text {; } \\
9.7-\mathrm{cm} \mathrm{CSS}, 51.3 \mathrm{~kg}\end{array}$ & Failed to crush largest pieces \\
\hline$S P-B$ & $\begin{array}{l}\text { From primary crusher test } \mathrm{CP}-\mathrm{L} \text {; } \\
5.3-\mathrm{cm} \mathrm{CSS}, 39.7 \mathrm{~kg}\end{array}$ & Complete crushing ( $1 \min 43 \mathrm{~s})$ \\
\hline $\mathrm{SP}-\mathrm{C}$ & $\begin{array}{l}\text { From primary crusher test CP-M; } \\
5.3-\mathrm{cm} \mathrm{CSS}, 70.4 \mathrm{~kg}\end{array}$ & $\begin{array}{l}\text { Shutdown after } 4 \text { min } 8 \mathrm{~s} \text { due } \\
\text { to overheated bearing }\end{array}$ \\
\hline$S P-D$ & $\begin{array}{l}\text { From primary crusher test DC-1; } \\
5.3-\mathrm{cm} \mathrm{CSS}, 44.9 \mathrm{~kg}\end{array}$ & Complete crushing ( 1 min $25 \mathrm{~s}$ ) \\
\hline
\end{tabular}

${ }^{(a)}$ Crusher speed $=300 \mathrm{rpm} ; \operatorname{CSS}=0.635 \mathrm{~cm}$. 
the motion of the pitman. This was attributed to the fact that these pieces were unable to enter the crushing cavity to a point where the probability for crushing is high. This was experimentally determined on the primary crusher as a $<14.5-\mathrm{deg}$ nip angle. The secondary crusher has a curved wear plate with a varying nip angle which reaches $14.5 \mathrm{deg}$ at the point where the gape (feed opening) is $27.4 \mathrm{~cm}$ at the maximum open pitman position. This reduces the probability of crushing fuel element materials greater than $7.4 \mathrm{~cm}$ in all dimensions. This was borne out by subsequent tests utilizing feed materials produced with a $5.3-\mathrm{cm} \operatorname{CSS}$ on the primary crusher.

Crushed materials from the tests demonstrating the primary crusher product characteristics were utilized as feed for tests demonstrating the secondary crusher product characteristics. These runs are sumarized in Table 3-6. These feed materials enabled a comparison to be made of secondary crusher products from unfueled half-size fuel and control rod elements and full-size fuel elements which had been processed through the primary crusher.

In general, secondary crushing was without major problems. However, in three of the seven runs, fuel element fragments in the secondary crushing cavity formed bridges connected loosely by interlocking of ridges formed at the fracture planes between coolant and fuel holes, (Fig. 3-11). These bridges formed masses which were greater than $7.4 \mathrm{~cm}$ in all dimensions and were therefore unable to enter the crushing cavity to the point where the probability for crushing is high. In no case did this occur with a single fragment. In run SC-15, an additional $9 \mathrm{~kg}$ of primary crusher product was charged on top of the bridge in an effort to reinstitute crushing. This was unsuccessful. The bridged material was then removed from the crusher and recharged as individual pieces. These pieces were readily crushed in a normal fashion. In the other two runs (SC-19 and -21$)$ in which bridges were formed, the bridges were disturbed by a steel rod which separated the interlocking pieces. This technique reinstituted crushing to 
TABLE 3-6

UNIFRAME SECONDARY CRUSHER PHASE I PRODUCT CHARACTERISTICS ${ }^{(a)}$

\begin{tabular}{|c|c|c|}
\hline Test & Feed Material & Result \\
\hline $\mathrm{SC}-13$ & $\begin{array}{l}\text { From primary crusher test } \mathrm{PC}-1 \text {; } \\
5.3-\mathrm{cm} \text { CSS, half standard fuel } \\
\text { element, } 43 \mathrm{~kg}\end{array}$ & Complete crushing $(1 \min 29 \mathrm{~s})$ \\
\hline $\mathrm{SC}-14$ & $\begin{array}{l}\text { From primary crusher test } \mathrm{PC}-2 \text {; } \\
5.3-\mathrm{cm} \mathrm{CSS} \text {, half standard fuel } \\
\text { element, } 45 \mathrm{~kg}\end{array}$ & Complete crushing ( 1 min $35 \mathrm{~s}$ ) \\
\hline $\mathrm{SC}-15$ & $\begin{array}{l}\text { From primary crusher test } \mathrm{PC}-3 \mathrm{~B} \text {; } \\
5.3-\mathrm{cm} \text { CSS, half standard fuel } \\
\text { element, } 44 \mathrm{~kg}\end{array}$ & $\begin{array}{l}\text { Complete crushing; abnormal } \\
\text { operating conditions imposed } \\
\text { owing to "bridged" material } \\
(1 \text { min } 43 \mathrm{~s})\end{array}$ \\
\hline $\mathrm{SC}-16$ & $\begin{array}{l}\text { From primary crusher test } \mathrm{PC}-4 \text {; } \\
5.3-\mathrm{cm} \text { CSS, half control rod } \\
\text { element, } 44 \mathrm{~kg}\end{array}$ & Complete crushing (2 min $46 \mathrm{~s}$ ) \\
\hline $\mathrm{SC}-19$ & $\begin{array}{l}\text { From primary crusher test } \mathrm{PC}-7 \text {; } \\
5.3-\mathrm{cm} \text { CSS, full-size fuel } \\
\text { element, } 91 \mathrm{~kg}\end{array}$ & $\begin{array}{l}\text { Complete crushing; abnormal } \\
\text { operating conditions imposed } \\
\text { owing to "bridged" material } \\
\text { ( } 3 \text { min } 32 \mathrm{~s} \text { ) }\end{array}$ \\
\hline $\mathrm{SC}-20$ & $\begin{array}{l}\text { From primary crusher test PC- } 8 \text {; } \\
5.3-\mathrm{cm} \text { CSS, full-size fuel } \\
\text { element, } 90 \mathrm{~kg}\end{array}$ & Complete crushing ( $3 \min 19 \mathrm{~s}$ ) \\
\hline $\mathrm{SC}-21$ & $\begin{array}{l}\text { From primary crusher test PC-9; } \\
5.3-\mathrm{cm} \text { CSS, full-size fuel } \\
\text { element, } 85 \mathrm{~kg}\end{array}$ & $\begin{array}{l}\text { Complete crushing; abnormal } \\
\text { operating conditions imposed } \\
\text { owing to "bridged" material } \\
(3 \text { min } 48 \mathrm{~s} \text { ) }\end{array}$ \\
\hline
\end{tabular}

${ }^{\text {(a) }}$ Crusher speed $=300 \mathrm{rpm} ; \mathrm{CSS}-0.635 \mathrm{~cm}$. 

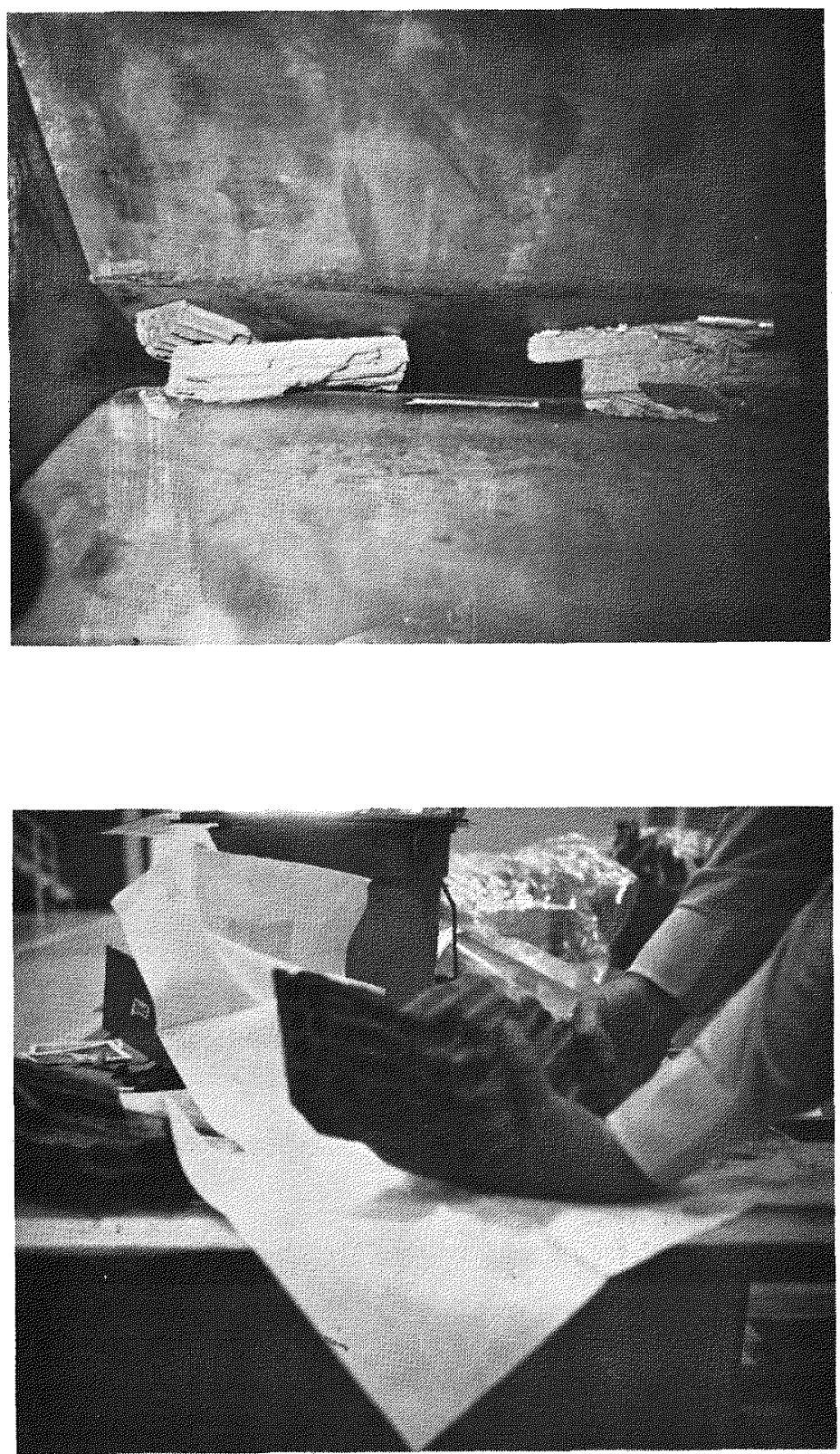

Fig. 3-11. Formation of bridges in fuel element fragments: (top) bridged fragments in test SC-15; (bottom) typical interlocking to form bridges 
completion. It was apparent that bridging of material in the secondary crusher was inevitable with this design. Therefore, means for eliminating this problem were devised, as described in Section 3.3.2.

Each of the products from the secondary crushing tests was inspected for large fragments (Table 3-7). Only two pleces greater than $1.9 m \mathrm{~cm}$ xing size were found in the $442 \mathrm{~kg}$ of materials processed in the seven tests. The products were separated into plus and minus $0.475-\mathrm{cm}$ fractions by hand screening. The size distributions of the products from the half-size and the full-size fuel elements remained similar after primary and secondary crushing (Table 3-7). The product from the single half-size control rod was somewhat smaller than the product from the standard fuel elements. The opposite tendency was observed in the primary tests, where the control rod product was larger.

Average secondary crushing throughput rates were $\sim 27 \mathrm{~kg} / \mathrm{min}$ for halfsize fuel elements, $225 \mathrm{~kg} / \mathrm{min}$ for full-size fuel elements, and $\sim 16 \mathrm{~kg} / \mathrm{min}$ for the half-size control rod element. The somewhat larger control rod product obtained after primary crushing apparently required an increased process time for secondary crushing. All crushing rates were well above those necessary to process a fuel element in less than $15 \mathrm{~min}$. In all the tests, matexials were totally confined to the crushing cavity. The configuration of the cavity was more than adequate to contain materials fed at rates equivalent to primary crusher discharge rates (i.e., $\sim 26$ to $\sim 110$ $\mathrm{kg} / \mathrm{min})$.

Aside from the bridging situations, material holdup was confined to an occasional small fragment ( $<10 \mathrm{~g}$, estimated) which appeared to have stuck to one of the wear plates in the narrow section of the cavity. In all cases these fragments were crushed with the succeeding charge. In addition, a small quantity of material was wedged into the clearance between the stationary jaw and the cheek plates. 
TABLE 3-7

UNIFRAME SECONDARY CRUSHER PHASE I PRODUCT CHARACTERIZATION STUDIES (a)

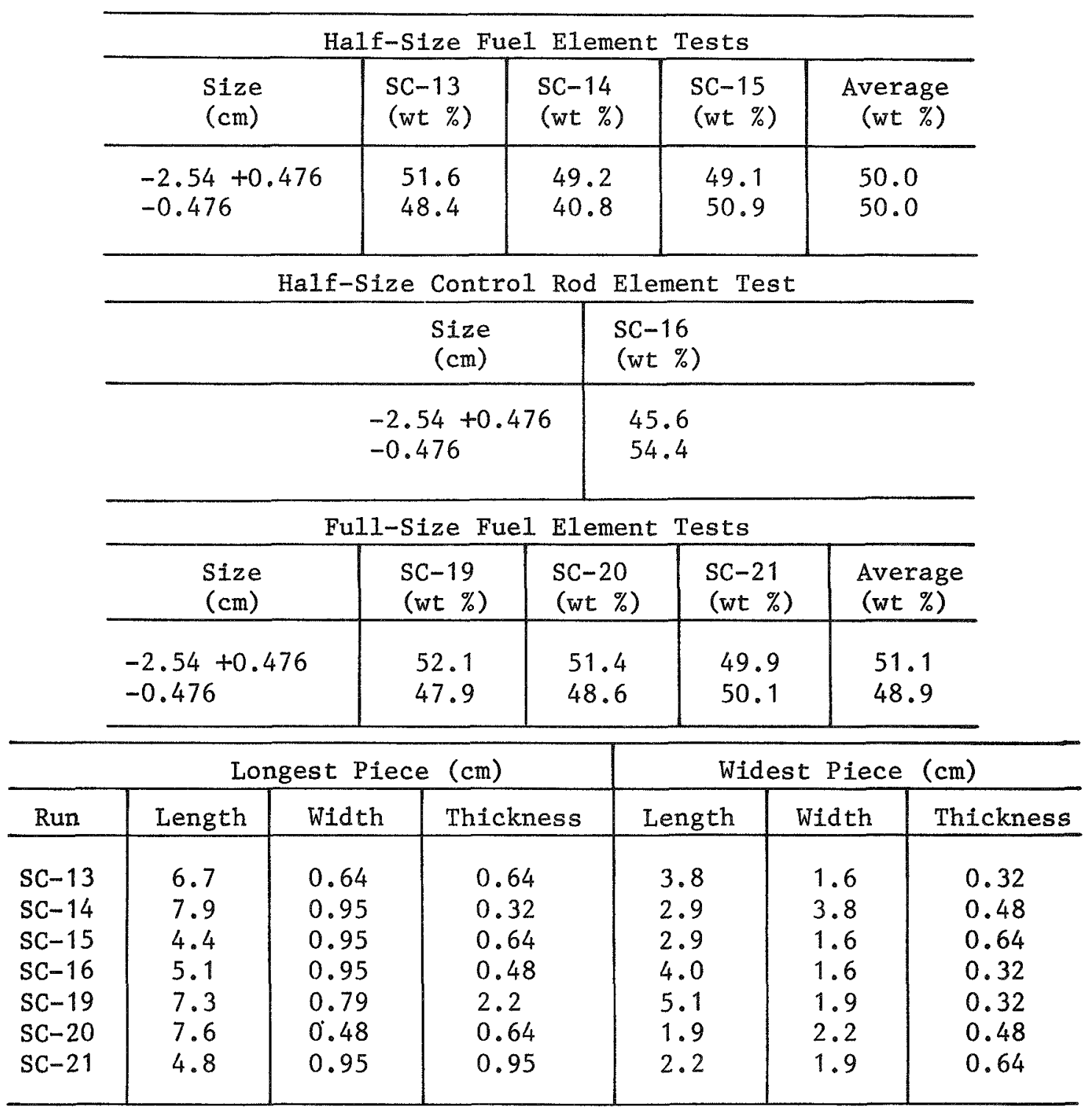

${ }^{(a)}$ Crusher speed $=300 \mathrm{rpm} ; \operatorname{CSS}=0.635 \mathrm{~cm}$. 


\subsubsection{Secondary Crusher Modifications}

3.3.2.1. Stationary Jaw. Design modifications were made to the secondary stationary $j a w$ and the wear plate of the secondary pitman to alleviate the problem of bridging of large fragements entering from the primary crusher. These modifications involved deepening the crushing cavity by approximately $20 \mathrm{~cm}$ and continuing the nominal 14-deg crushing angle between the stationary $j$ aw and the pitman wear plate for the full depth of the cavity. These changes permit the secondary crusher to accept and crush fragments up to a $15-\mathrm{cm}$ ring size at the $14-\mathrm{deg}$ angle.

lfodification to the stationary jaw consisted of extending one of the crushing faces by approximately $9.5 \mathrm{~cm}$. The changes in the wear plate of the pitman wear plate assembly were more extensive, including not only extension of the crushing face but also creation of a flat surface on the extension and the unaltered portion of the wear plate. As a result of these changes, the depth and opening of the crushing cavity were increased, and the maximum nominal nip angle was prevented from exceeding 14 deg. These modifications are shown in Fig. 3-12. Figures $3-13$ and 3-14 illustrate the difference in the pitman wear plate before and after modification. The modifications to the components were evaluated during shakedown testing prior to phase II system tests.

\subsubsection{Pitman Bearings. The problem of overheating secondary pitman} bearings encountered in phase I testing was determined to have resulted from improperly fitted bronze bearing sleeves. New sleeves were installed and bored for proper clearance of the shafts. The units were refitted on the pitman shaft and installed in the UNIFRAME with the modified secondary pitman assemb1y.

\subsection{TERTIARY CRUSHER TESTING}

The tertiary crusher is a double-roll crusher consisting of two 100-cm-diameter, 70-cm-wide rolls separated by a $0.276-\mathrm{cm}$ gap. Each roll 


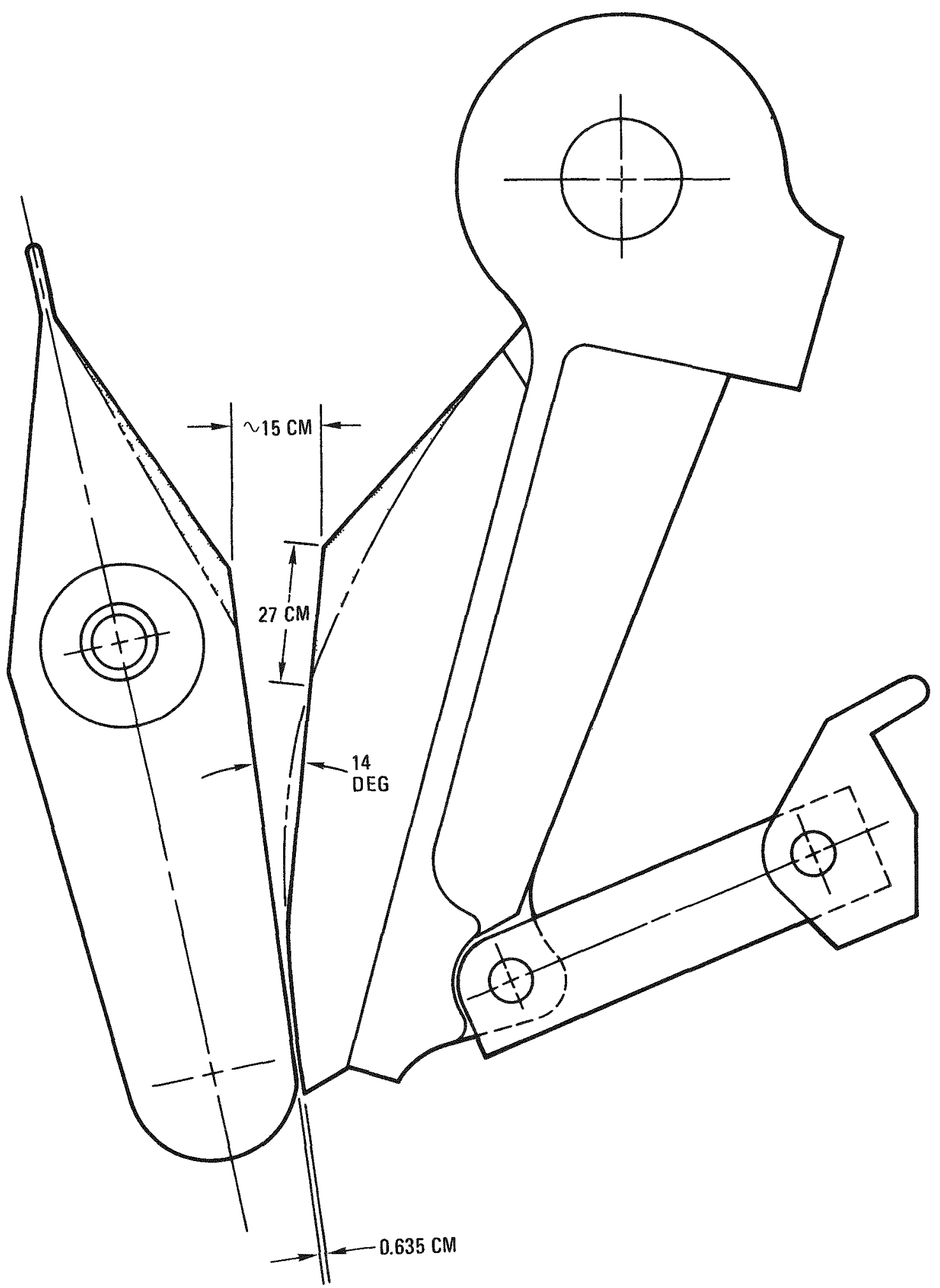

Fig. 3-12. Secondary crusher modification showing deeper crushing cavity and 14-deg nip angle 


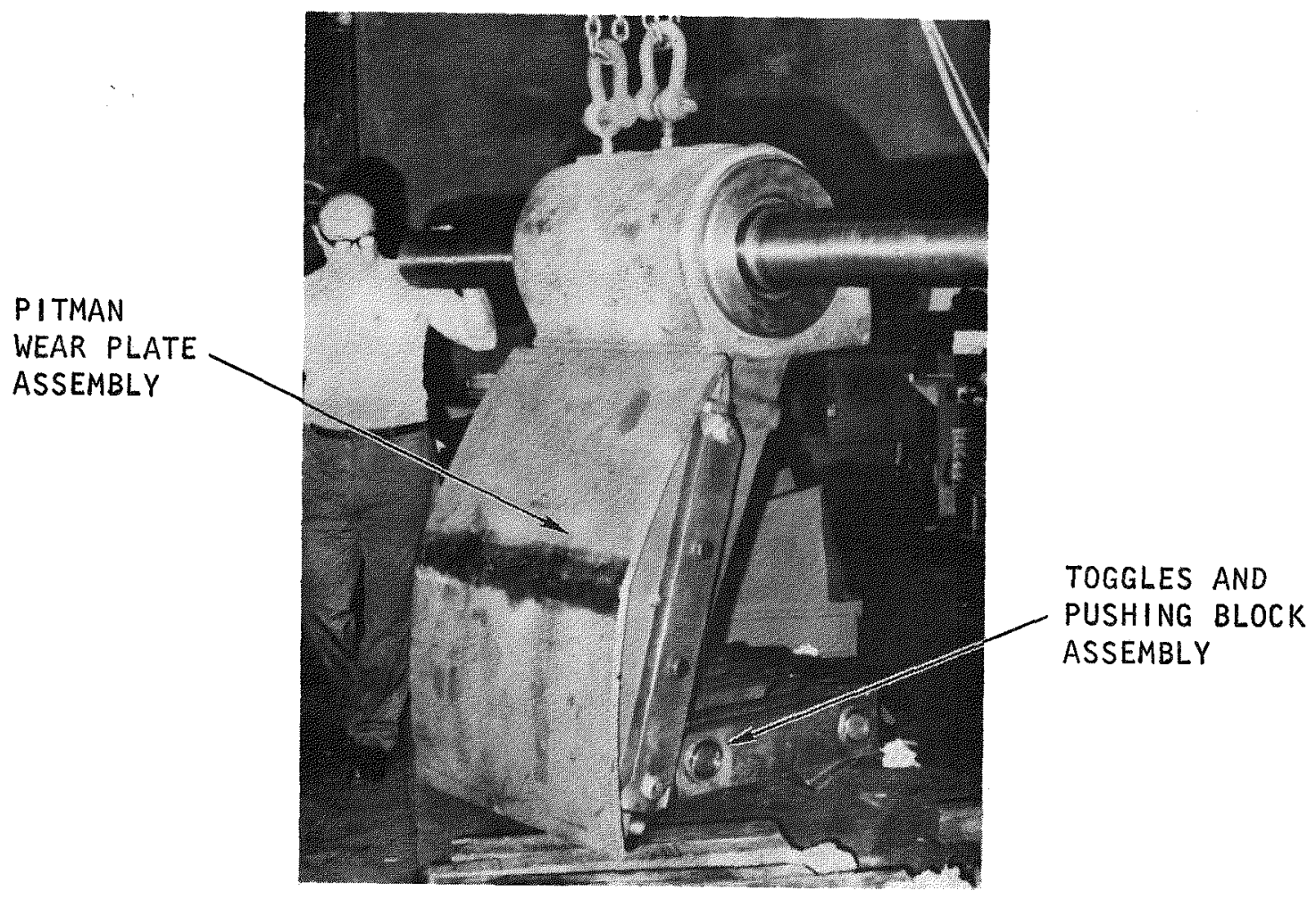

Fig. 3-13. Secondary crusher pitman assembly with original wear plate

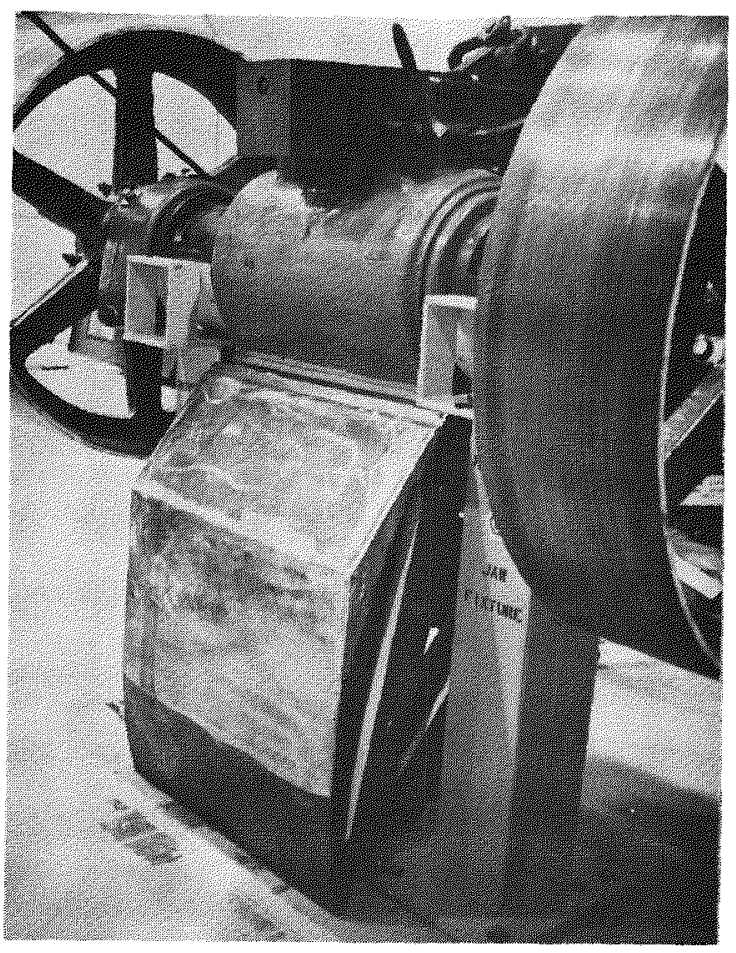

Fig. 3-14. Secondary crusher pitman assembly with modified wear plate and machined flat 
is independently driven at approximately $60 \mathrm{rpm}$ by a constant-speed motor and an in-Iine, directly coupled speed reducer. The drives are connected through synchronous toothed belts to a drive sprocket on each roll shaft.

The operational and design capabilities of the tertiary crusher were tested using crushed graphite products from the secondary crusher tests. The feed materials included products from primary and secondary crushing of three half-length, unfueled H-327 graphite fuel elements, one halflength, unfueled $\mathrm{H}-327$ graphite control rod element, and three full-length, unfueled $\mathrm{H}-327$ graphite fuel elements. Each of these materials was separately charged to the tertiary crusher at rates approximately equal to the rate at which they were crushed in the secondary crusher. Observations of material flows during the crushing operations and inspection of the crusher after the test revealed no material holdup areas or material bypassing the crushing cavity.

In all the tests, the material was crushed as rapidly as it was charged. Therefore, no material surges are expected to occur between the secondary and tertiary crushing stages when the equipment is operated as a system. The maximum feed rate was approximately $33.7 \mathrm{~kg} / \mathrm{min}$, and tertiary crushing rates were at least equivalent. The required throughput of one fuel element in $<15$ min ( $\sim 113 \mathrm{~kg} /$ element $=\sim 7.53 \mathrm{~kg} / \mathrm{min}$ ) is easily achieved in the tertiary crushing stage. Table 3-8 summarizes the tertiary crusher tests.

Crushed products from each of the tests were hand-screened through a 4750- $\mu \mathrm{m}$ screen (with some actual measured maximum openings of $5512 \mu \mathrm{m}$ due to screen wear). As shown in Table $3 m$, there were no significant differences between fuel and control rod elements or between half- and fullsize elements in the quantities of $+4750-\mu$ material produced in tertiary crushing. The $+4750-\mu \mathrm{m}$ size fraction averaged $1.0 \mathrm{wt} \%$ of the product and ranged from a high of 1.3 to a low of 0.5 wt $\%$ 
TABLE 3-8

UNIFRAME TERTIARY CRUSHER PHASE I TESTS ${ }^{(a)}$

\begin{tabular}{|c|c|c|}
\hline Test & Feed Material & Result \\
\hline $\mathrm{TC}-25$ & $\begin{array}{l}\text { Half fuel element after primary } \\
\text { (test PC-1) and secondary (test } \\
\text { SC-13) crushing; } 42.6 \mathrm{~kg}\end{array}$ & $\begin{array}{l}\text { Complete crushing at charging } \\
\text { rate }(1 \min 29 \mathrm{~s}) ; 28.7 \mathrm{~kg} / \mathrm{min}\end{array}$ \\
\hline $\mathrm{TC}-26$ & $\begin{array}{l}\text { Half fuel element after primary } \\
\text { (test PC-2) and secondary (test } \\
\text { SC-14) crushing; } 43.3 \mathrm{~kg}\end{array}$ & $\begin{array}{l}\text { Complete crushing at charging } \\
\text { rate }(1 \text { min } 25 \mathrm{~s}) ; 30.6 \mathrm{~kg} / \mathrm{min}\end{array}$ \\
\hline TC-27 & $\begin{array}{l}\text { Half fuel element after primary } \\
\text { (test } \mathrm{PC}-3 \mathrm{~B} \text { ) and secondary } \\
\text { (test SC-15) crushing; } 51.7 \mathrm{~kg}\end{array}$ & $\begin{array}{l}\text { Complete crushing at charging } \\
\text { rate }(1 \mathrm{~min} 32 \mathrm{~s}) ; 33.7 \mathrm{~kg} / \mathrm{min}\end{array}$ \\
\hline $\mathrm{TC}-28$ & $\begin{array}{l}\text { Half control rod element after } \\
\text { primary (test PC-4) and second- } \\
\text { ary (test SC-16) crushing; } \\
41.5 \mathrm{~kg}\end{array}$ & $\begin{array}{l}\text { Complete crushing at charging } \\
\text { rate }(2 \min 46 \mathrm{~s}) ; 15.0 \mathrm{~kg} / \mathrm{min}\end{array}$ \\
\hline $\mathrm{TC}-31$ & $\begin{array}{l}\text { Full-size fuel element after } \\
\text { primary (test PC-7) and second- } \\
\text { ary (test SC-19) crushing; } \\
85.7 \mathrm{~kg}\end{array}$ & $\begin{array}{l}\text { Complete crushing at charging } \\
\text { rate }(3 \mathrm{~min} 32 \mathrm{~s}) ; 24.3 \mathrm{~kg} / \mathrm{min}\end{array}$ \\
\hline $\mathrm{TC}-32$ & $\begin{array}{l}\text { Full-size element after primary } \\
\text { (test PC-8) and secondary (test } \\
\text { SC-20) crushing; } 87.1 \mathrm{~kg}\end{array}$ & $\begin{array}{l}\text { Complete crushing at charging } \\
\text { rate }(3 \mathrm{~min} 19 \mathrm{~s}) ; 26.3 \mathrm{~kg} / \mathrm{min}\end{array}$ \\
\hline $\mathrm{TC}-33$ & $\begin{array}{l}\text { Full-size fuel element after } \\
\text { primary (test PC-9) and second- } \\
\text { ary (test SC-21) crushing; } \\
87.1 \mathrm{~kg}\end{array}$ & $\begin{array}{l}\text { Complete crushing at charging } \\
\text { rate }(3 \mathrm{~min} 30 \mathrm{~s}) ; 24.9 \mathrm{~kg} / \mathrm{min}\end{array}$ \\
\hline
\end{tabular}

(a) ${ }_{\text {Roll gap }}=2770 \mu \mathrm{m}$; roll speed $=60 \mathrm{rpm}$. 
TABLE $3-9$

UNIFRAME TERTIARY CRUSHER PHASE I TESTS - PRODUCT SIZE DISTRIBUTION Rol1 Gap: $2770 \mu \mathrm{m}(0.109 \mathrm{in.})$; Roll Speed: $60 \mathrm{rpm}$

\begin{tabular}{|c|c|c|}
\hline Test & $\begin{array}{c}\text { Wt \% } \\
+4750-\mu \mathrm{m} \\
\text { Material } \\
\end{array}$ & $\begin{array}{c}\text { Wt \% } \\
-4750-\mu \mathrm{m} \\
\text { Material }\end{array}$ \\
\hline \multicolumn{3}{|c|}{$1 / 2$ Fuel Element Crushing } \\
\hline $\mathrm{TC}-25$ & 1.3 & 98.7 \\
\hline $\mathrm{TC}-26$ & 0.5 & 99.5 \\
\hline $\mathrm{TC}-27$ & 0.8 & 99.2 \\
\hline Average & 0.9 & 99.1 \\
\hline \multicolumn{3}{|c|}{$1 / 2$ Control Rod Element Crushing } \\
\hline $\mathrm{TC}-28$ & 1.0 & 99.0 \\
\hline \multicolumn{3}{|c|}{ Full-Size Fuel Element Crushing } \\
\hline $\mathrm{TC}-31$ & 0.8 & 99.2 \\
\hline $\mathrm{TC}-32$ & 1.3 & 98.7 \\
\hline $\mathrm{TC}-33$ & 1.1 & 98.9 \\
\hline Average & 1.1 & 98.9 \\
\hline Grand average & 1.0 & 99.0 \\
\hline
\end{tabular}


The -4750- $\mu \mathrm{m}$ size fraction from each test was reduced in a 12-to-1 sample splitter to a size suitable for subsequent screen analysis using 20.32-cm-diameter Tyler standard screen sieves. The results of these analyses (Table 3-10) again indicated no significant differences in the products from tertiary crushing for fuel or control rod elements or for half- or full-size elements. Figure 3-15 shows the three-run average size distributions for the half- and full-size fuel elements and the single control rod element.

\subsection{OVERSIZE CRUSHER TESTING}

The oversize crusher is a standard Centerol crusher consisting of a single roll $(20 \times 10 \mathrm{~cm})$ mounted on an eccentric shaft between two wear plates and driven by a 5-hp motor through V-belts. For the UNIFRAME system, charging and discharging chutes and cover plates were added to avoid material and dust escape. It was estimated that the maximum throughput of the oversize crusher would be $10 \mathrm{wt} \%$ of the entire fuel element during the allowable $15-\mathrm{min}$ crushing period, or $0.75 \mathrm{~kg} / \mathrm{min}$. It was also estimated that the composition of the feed could be up to 5 wt \% of the fuel element as $+4750-\mu \mathrm{m}$ material from oversize product passing through the tertiary crushing stage and up to $5 \mathrm{wt} \%$ of the fuel element as $-4750-\mu \mathrm{m}$ material from screener inefficiencles.

To gain insight into the operation of the oversize crusher prior to beginning the parametric studies, two shakedown tests (OP-A and $O P-B$ ) were performed. The feed materials for both tests were made by blending $5.57 \mathrm{~kg}$ (equivalent to $5 \mathrm{wt} \%$ of one fuel element) of $+4750-\mu \mathrm{m}$ crushed graphite and $5.67 \mathrm{~kg}$ of $-4750-\mu \mathrm{m}$ crushed graphite from the secondary crusher. In the initial test $(\mathrm{OP}-\mathrm{A})$, the blended feed was charged at a rate of $\sim 4 \mathrm{~kg} / \mathrm{min}$ and was crushed as rapidly as it was charged. In the second test $(O P-B)$, the blended feed was choke fed to the crusher to obtain an estimate of the maximum throughput rate. Crushing was completed in $\sim 50 \mathrm{~s}$, resulting in a throughput rate of $213.6 \mathrm{~kg} / \mathrm{min}$. The products from these tests were handscreened through a standard 4750- $\mu \mathrm{m}$ mesh screen (actual measured maximum 
TABLE $3-10$

UNIFRAME TERTIARY CRUSHER 5512- $\mu \mathrm{m}$ PRODUCT

SIZE DISTRIBUTIONS - PHASE I TESTS

Ro11 Gap: $2770 \mu \mathrm{m}$ (0.109 in.); Ro11 Speed: $60 \mathrm{rpm}$

\begin{tabular}{c|r|r|r|r|r|r|r|r}
\hline & \multicolumn{9}{|c|}{ Crushed Half-Size Fuel Elements } \\
\cline { 2 - 9 } $\begin{array}{c}\text { Mesh Size } \\
(\mu \mathrm{m})\end{array}$ & \multicolumn{2}{|c|}{ TC-25 } & \multicolumn{2}{c|}{ TC-26(a) } & \multicolumn{2}{c|}{ TC-27 } & \multicolumn{2}{c}{ Avg. } \\
\hline & Wt $\%$ & Cum. & & Cum. & & Cum. & \multicolumn{3}{|c}{ Cum. } \\
\hline$-4750+4000$ & 17.8 & 100.0 & 13.9 & 100.0 & 14.8 & 100.0 & 15.5 & 100.0 \\
$-4000+2800$ & 43.2 & 82.2 & 36.6 & 86.1 & 40.5 & 85.2 & 40.1 & 84.5 \\
$-2800+2000$ & 12.0 & 39.0 & 12.8 & 49.5 & 14.2 & 44.7 & 13.0 & 44.4 \\
$-2000+1000$ & 11.2 & 27.0 & 13.5 & 36.7 & 13.8 & 30.5 & 12.8 & 31.4 \\
$-1000+850$ & 1.9 & 15.8 & 2.6 & 23.2 & 2.4 & 16.7 & 2.3 & 18.6 \\
$-850+425$ & 5.8 & 13.9 & 8.2 & 20.6 & 6.9 & 14.3 & 7.0 & 16.3 \\
$-425+355$ & 1.2 & 8.1 & 1.8 & 12.4 & 1.3 & 7.4 & 1.4 & 9.3 \\
$-355+250$ & 1.6 & 6.9 & 2.6 & 10.6 & 1.7 & 6.1 & 2.0 & 7.9 \\
-250 & 5.3 & 5.3 & 8.0 & 8.0 & 4.4 & 4.4 & 5.9 & 5.9 \\
\hline
\end{tabular}

Crushed Half-Size Control Rod Element

\begin{tabular}{c|r|r}
\hline \multirow{2}{*}{$\begin{array}{c}\text { Mesh Size } \\
(\mu \mathrm{m})\end{array}$} & \multicolumn{2}{|c}{ TC-28 } \\
\cline { 2 - 3 } & Wt $\%$ & \multicolumn{1}{|c}{ Cum $\%$} \\
\hline$-4750+4000$ & 16.1 & 100.0 \\
$-4000+2800$ & 40.0 & 83.9 \\
$-2800+2000$ & 12.4 & 43.9 \\
$-2000+1000$ & 11.2 & 31.5 \\
$-1000+850$ & 2.2 & 20.3 \\
$-850+425$ & 7.3 & 18.1 \\
$-425+355$ & 1.6 & 10.8 \\
$-355+250$ & 2.3 & 9.2 \\
-250 & 6.9 & 6.9 \\
\hline
\end{tabular}

Crushed Full-Size Fuel Elements

\begin{tabular}{|c|c|c|c|c|c|c|c|c|}
\hline \multirow[b]{2}{*}{$\begin{array}{c}\text { Mesh Size } \\
(\mu \mathrm{m})\end{array}$} & \multicolumn{2}{|c|}{$\mathrm{TC}-31$} & \multicolumn{2}{|c|}{$\mathrm{TC}-32^{(\mathrm{a})}$} & \multicolumn{2}{|c|}{$\mathrm{TC}-33$} & \multicolumn{2}{|c|}{ Avg. } \\
\hline & Wt \% & $\begin{array}{l}\text { Cum. } \\
\text { Wt \% }\end{array}$ & Wt \% & $\begin{array}{l}\text { Cum. } \\
\text { Wt \% }\end{array}$ & Wt \% & $\begin{array}{l}\text { Cum. } \\
\text { Wt \% }\end{array}$ & Wt \% & $\begin{array}{l}\text { Cum. } \\
\text { Wt \% }\end{array}$ \\
\hline$-4750+4000$ & 15.7 & 100.0 & 18.3 & 100.0 & 14.8 & 100.0 & 16.3 & 100.0 \\
\hline$-4000+2800$ & 40.4 & 84.3 & 39.8 & 81.7 & 38.3 & 85.2 & 39.5 & 83.7 \\
\hline$-2800+2000$ & 12.2 & 43.9 & 12.8 & 41.9 & 12.7 & 46.9 & 12.6 & 44.2 \\
\hline$-2000+1000$ & 11.8 & 31.7 & 11.3 & 29.1 & 12.6 & 34.2 & 11.9 & 31.6 \\
\hline$-1000+850$ & 2.2 & 19.9 & 2.0 & 17.8 & 2.4 & 21.6 & 2.2 & 19.7 \\
\hline$-850+425$ & 7.1 & 17.7 & 6.6 & 15.8 & 7.8 & 19.2 & 7.2 & 17.5 \\
\hline+355 & 1.5 & 10.6 & 2.0 & 9.2 & 2.4 & 11.4 & 2.0 & 10.3 \\
\hline+250 & 2.1 & 9.1 & 1.8 & 7.2 & 2.3 & 9.0 & 2.0 & 8.3 \\
\hline-250 & 7.0 & 7.0 & 5.4 & 5.4 & 6.7 & 6.7 & 6.3 & 6.3 \\
\hline
\end{tabular}

(a) Average of two screen analyses. 


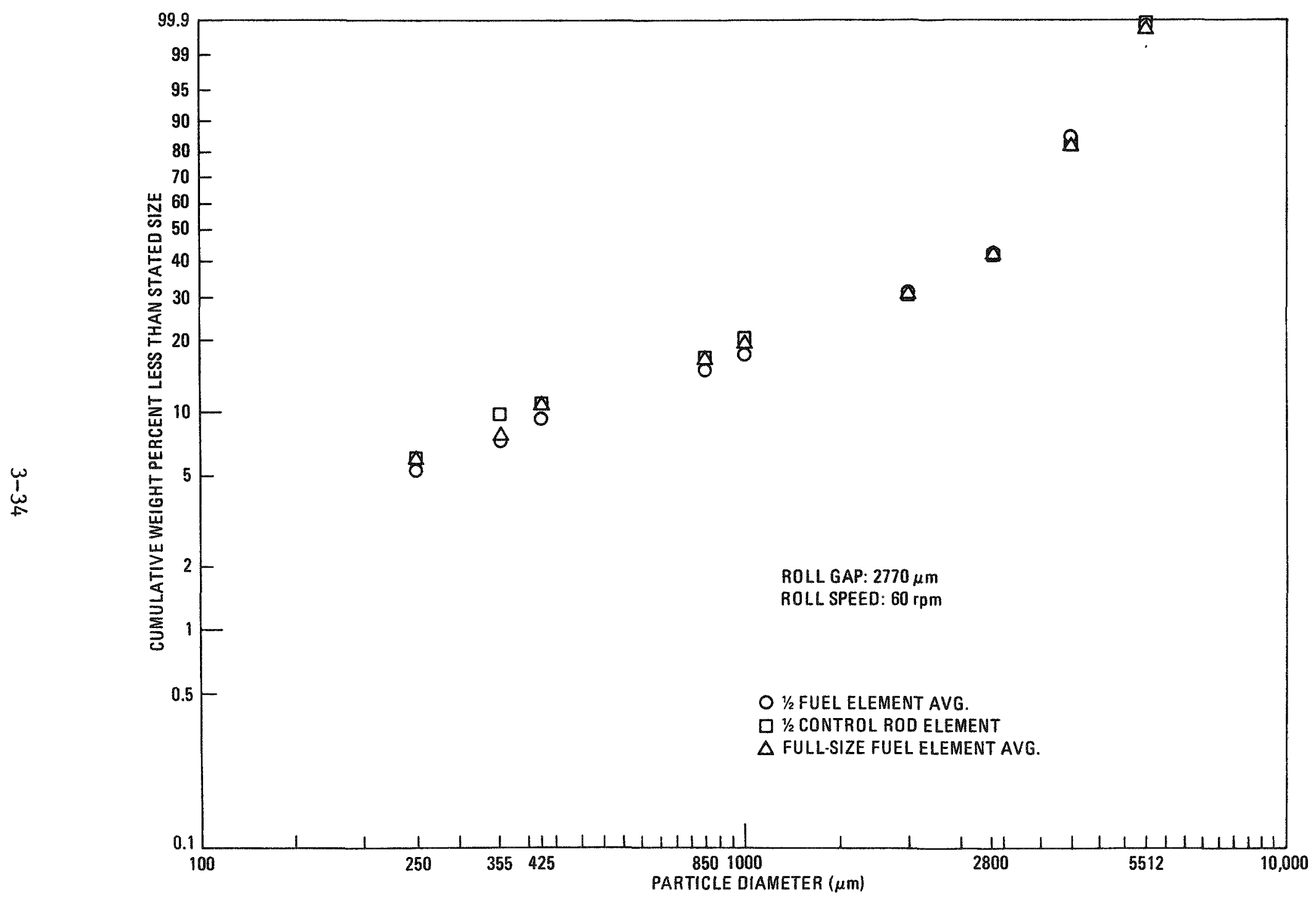

Fig. 3-15. -5512- $\mu$ m product size distributions from UNIFRAME tertiary crusher phase I tests 
openings $=5512 \mu \mathrm{m})$. The quantity of $+4750-\mu \mathrm{m}$ material in the product was very high for both tests (33.3 wt \% in $\mathrm{OP}-\mathrm{A}$ and $15.2 \mathrm{wt} \%$ in $\mathrm{OP}-\mathrm{B}$ ). The results of these tests are summarized in Table 3-11. To avoid excessive oversize material in subsequent tests, the original shaft with $0.318-\mathrm{cm}$ eccentricity was replaced by a shaft with a $0.159-\mathrm{cm}$ eccentricity to increase the size reduction. The gaps between the roll and the two wear plates were set by adjusting the wear plates inward to the point of contact with the roll at its maximum eccentricity. This resulted in a gap at the maximum open position which was equal to the shaft eccentricity.

As in the first two tests, the initial test with the $0.159-\mathrm{cm}$ eccentric shaft utilized feed made from secondary crusher product. However, owing to a weighing error, the quantity was increased to $7.71 \mathrm{~kg}$ for each fraction (Table 3-11). Nevertheless, the oversize material $(+4750 \mu \mathrm{m})$ in the product was reduced to $0.1 \mathrm{wt} \%$, and the throughput rate of $3.5 \mathrm{~kg} / \mathrm{min}$ was still in excegs of the estimated requirement of $0.75 \mathrm{~kg} / \mathrm{min}$.

At this point, the limited supply of $+4750-\mu m$ crushed graphite from the secondary crusher had been depleted. Additional $+4750-\mu \mathrm{m}$ feed materials were made by recrushing the smallest ring-size fractions from primary crusher tests in the oversize crusher. The gaps between the roll and the wear plate were adjusted to allow this operation. The material failed to crush in the succeeding test (OC-44A), apparently owing to improper resetting of the gaps after feed makeup crushing was completed. The gaps were reset to the point of contact with the roll at its maximum eccentricity, and the tests continued without further crushing failures.

Throughput rates for all tests utilizing the $0.159-\mathrm{cm}$ eccentric shaft and feeds equivalent to $10 \mathrm{wt} \%$ of an entire fuel element were greater $(2.0$ $\mathrm{kg} / \mathrm{min}$ minimum) than the $0.75-\mathrm{kg} / \mathrm{min}$ estimated requirement (Table $3-11$ ). At the highest rate obtained $(3.5 \mathrm{~kg} / \mathrm{min}$ in $0 \mathrm{C}-43)$, approximately $45 \%$ of an entire fuel element could be crushed in the oversize crusher in the allotted 15-min period. 
TABLE $3-11$

SUMMARY OF UNIFRAME OVERSIZE CRUSHER PHASE I TESTS

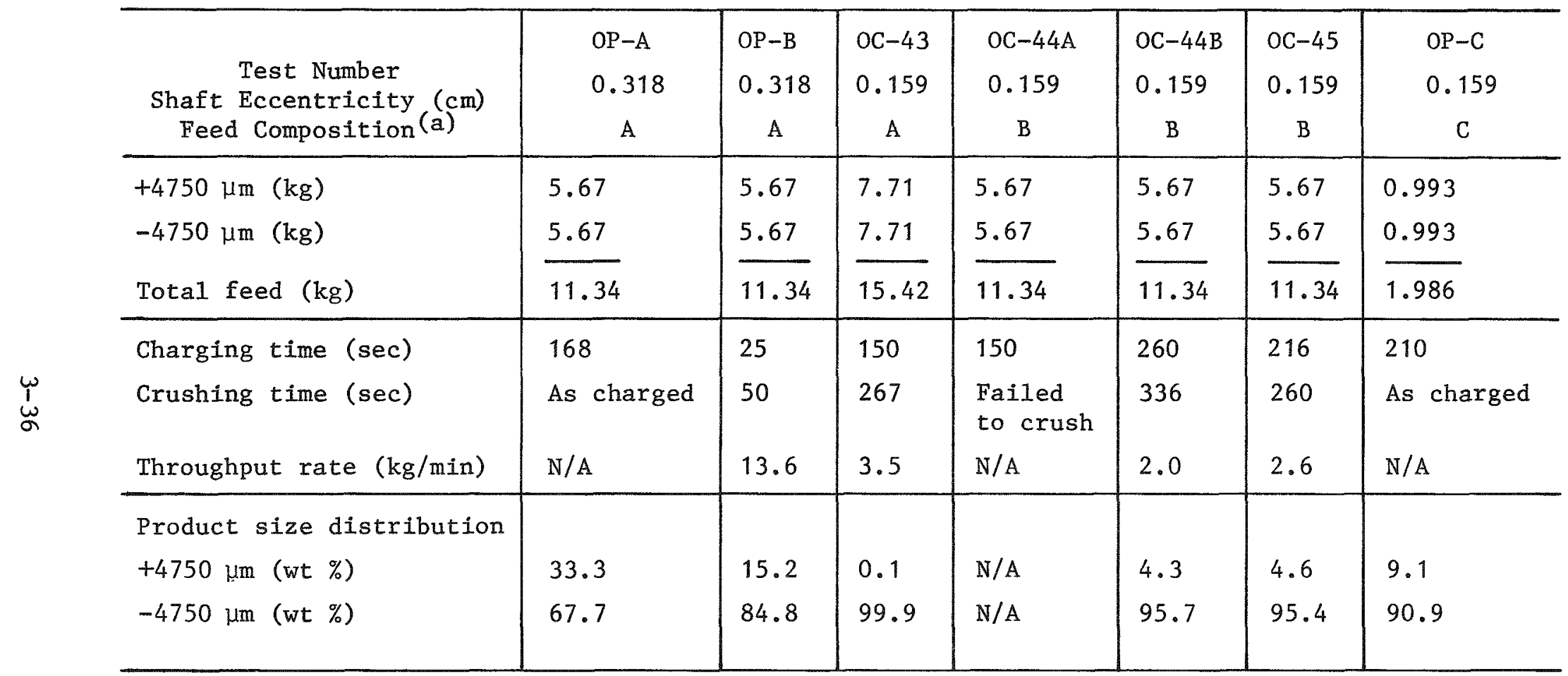

(a) $\mathrm{A}=$ Crushed $\mathrm{H}-327$ graphite from secondary crushing tests.

$B=$ Crushed $\mathrm{H}-327$ graphite $(+4750 \mu \mathrm{m})$ from primary crusher products recrushed in oversize crusher; crushed H-327 graphite $(-4750 \mu \mathrm{m})$ from secondary crushing tests.

$\mathrm{C}=$ Crushed $\mathrm{H}-327$ graphite $(+4750 \mu \mathrm{m})$ from tertiary crusher test $\mathrm{TC}-33$; crushed $\mathrm{H}-327$ graphite $(-4750 \mu \mathrm{m})$ from secondary crushing tests. 
Weight percents of $+4750-\mu \mathrm{m}$ material in the products ranged from a high of $4.6(\mathrm{OC}-45)$ to a low of $0.1(\mathrm{OC}-43)$. The higher percentages observed in $\mathrm{OC}-44$ and $\mathrm{OC}-45$ may have been the result of using the coarser feed made from recrushed primary crusher products. These results correspond to a maximum of $0.46 \%+4750-\mu \mathrm{m}$ material which could be expected to end up in the final UNIFRAME product.

A final test $(\mathrm{OP}-\mathrm{C})$ was conducted to simulate oversize crushing conditions with actual tertiary crusher product (Table 3-11). The feed for this test was the entire quantity of $+4750-\mu$ material from the product of a tertiary crusher test (TC-33) blended with an equal amount of $-4750-\mu \mathrm{m}$ material. The blended feed was charged to the oversize crusher at a rate equal to the tertiary crushing rate, and it was crushed as rapidly as it was charged. The weight percent of $+4750-\mu \mathrm{m}$ material in this oversize product was $9.1 \%$. This corresponds to 0.21 wt $\%$ of $+4750-\mu \mathrm{m}$ material which could be expected to end up in the final UNIFRAME product.

At the end of test $O C-45$, the oversize crusher was inspected for material holdup. Approximately $360 \mathrm{~g}$ of material was found in back of the two wear plates. This represented material holdup from tests $0 C-43$ through oC -45 , in which a total of $49.44 \mathrm{~kg}$ of material had been crushed, or $0.7 \%$ holdup. No detectable holdup was found after test $\mathrm{OP}-\mathrm{C}$; this was attributed to the choke feeding conditions in tests $O C-43$ through OC- 45 which forced material through the small spaces between the wear and side plates of the crusher. Although this apparently did not occur under the crushing conditions expected in the UNIFRAME (test OP-C), modifications to the oversize crusher are under study to avoid this potential problem.

\subsection{SCREENER TESTING}

The screener consists of two major components: a single, stationary outer housing and an inner vibrating section. The outer housing acts as part of the ventilation enclosure, as a discharge hopper to the material 
transport system, and as a support for the inner vibrating section. The design of the outer housing avoids transmission of necessary screening motions and vibrations to other parts of the UNIFRAME. The inner vibrating section consists of a centrally located motion generator (weights mounted on each end of the shaft of a 1/2-hp electric motor) and a perforated-plate screening table. Material passing through the perforated plate discharges onto the cone-shaped base of the outer housing and into the material transport system. The oversize materia1 discharges through a chute to the oversize crusher for further size reduction.

Initial screening shakedown tests revealed that many of the holes in the perforated plate were being blinded by lodged graphite particles. This blinding could eventually result in an inefficiency in the separation of acceptable and oversize materials and could require maintenance to clear the blinded holes, which would be unacceptable in a hot cell. This problem was initially attributed to the length-to-diameter ratio of the holes, which allowed particles with dimensions approaching that of the hole diameter to lodge easily. To study the effect of reducing the length-todiameter ratio, the holes in a 15-cm-diameter section of the perforated plate were chamfered ( $1 \mathrm{~cm} \times 45 \mathrm{deg}$ ). Blinding was noticeably reduced in this section compared with the original hole configuration, but was still too severe $(>10 \%)$ to be acceptable. A $15-\mathrm{cm}$ square section of the plate was replaced with $4750-\mu \mathrm{m}$ wire mesh screen, and blinding was reduced to $<5 \%$. The test array for the two modifications is shown in Fig. 3-16. These results prompted replacement of the entire perforated plate with a wire mesh screen for the screener operational and parametric tests (Figs. $3-17$ and $3-18$ ).

Motion generator adjustments greatly influence the flow characteristics of the material on the screen surface and therefore the screening efficiency. The vertical amplitude is increased by increasing the bottom eccentric weight. The lead angle (angle between the top and bottom eccentric weights) affects the material flow pattem across the surface of the 


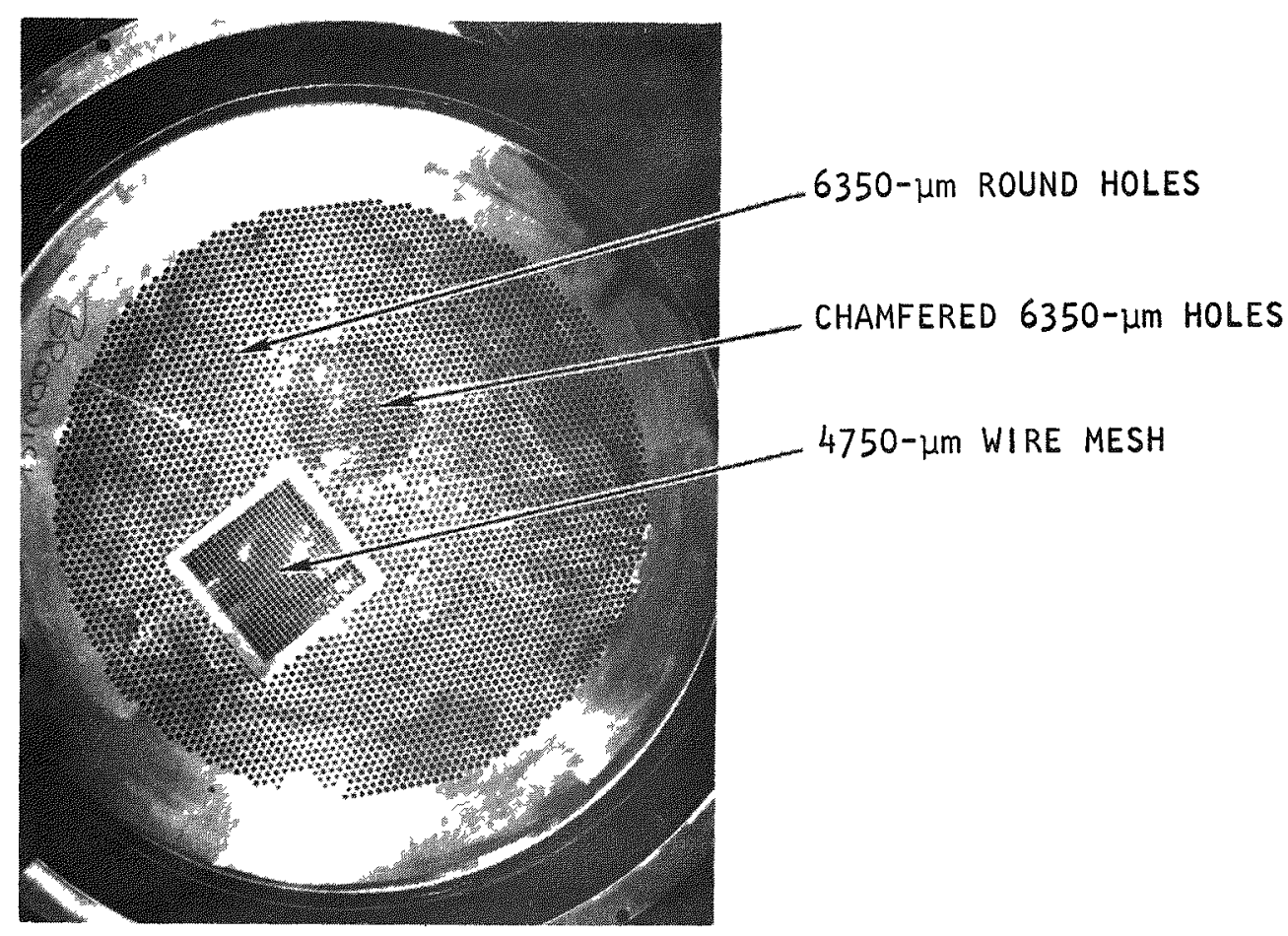

Fig. 3-16. Screener with perforated plate modified for blinding tests

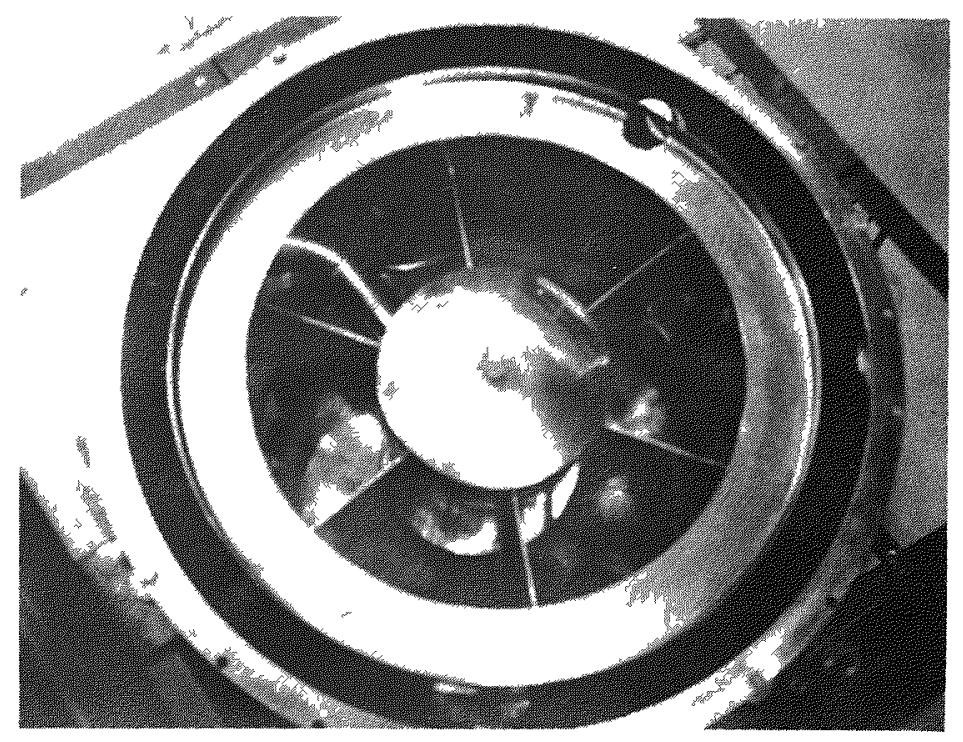

Fig. 3-17. Screener with perforated plate removed 


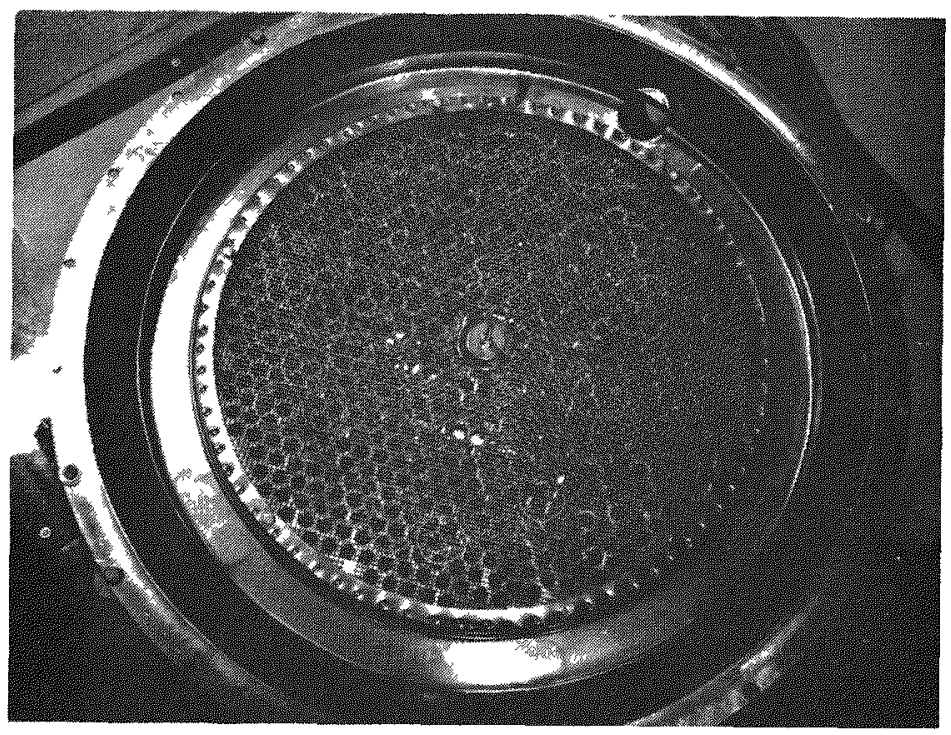

Fig. 3-18. Screener showing 4750- $\mu \mathrm{m}$ wire mesh screen installed

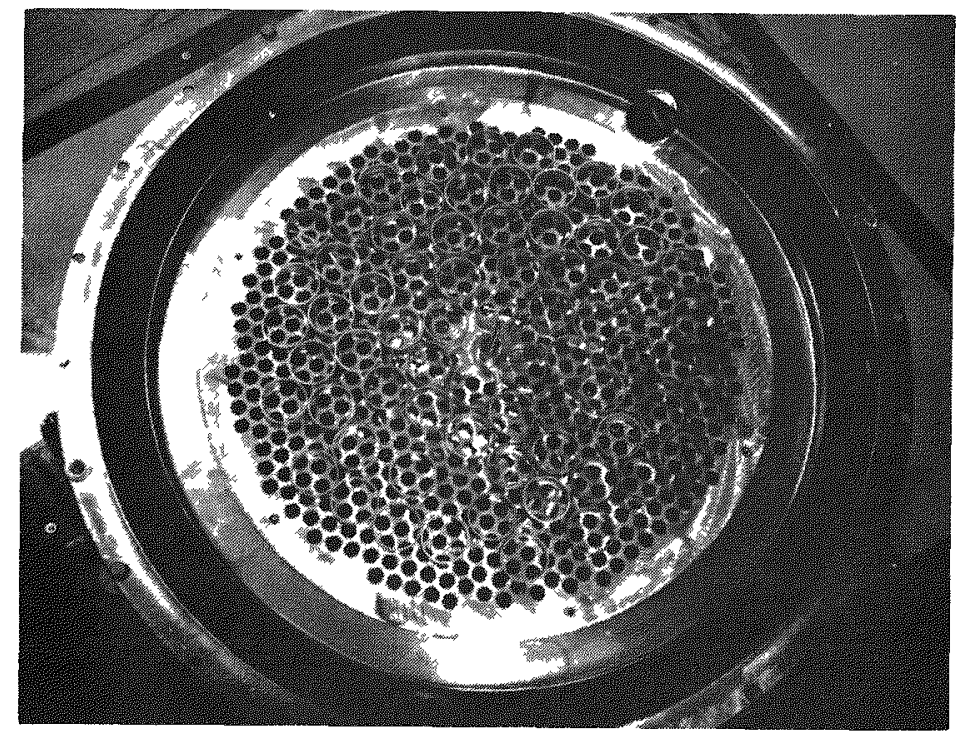

Fig. 3-19. Screener with self-cleaning kit installed (screen removed) 
screen. To study and optimize the screener efficiency, the motion generator adjustments were varied through a series of tests (Table 3-12) in which batches (145 $\mathrm{kg}$ each) of crushed graphite consisting entirely of acceptable material (i.e., $-4750-\mu \mathrm{m}$ mesh size) were charged and screened at the various motion generator settings. The quantity of material which discharged through the oversize chute indicated the screening efficiency at that motion generator setting. It was found that each 10-deg increase of the lead angle from 35 to 65 deg produced an increase in screening efficiency and that the increases were larger as the angles grew larger. At the 65-deg lead angle, the material showed a tendency to move inward toward the center of the screen and away from the discharge chute, thereby increasing the probability of material remaining on the screen.

Removal of one of the bottom weights produced increases in efficiency which were larger than those produced by any of the tested 10-deg incremental lead angle changes. To avoid material holdup on the screen while achieving maximum efficiency, a lead angle of 55 deg with one bottom weight was selected for further tests.

Although the screener blinding remained lower with the wire mesh screen than it had been with the perforated plate, a gradual increase in the number of blinded holes was observed during the screener efficiency studies. To determine the extent of this buildup, batch screening was continued using the selected motion generator settings, and the number of blinded holes in one quadrant of the screen were periodically counted. The degree of blinding was calculated from an estimate of the total number of holes available (Table 3-13). Screening efficiencies remained fairly constant throughout the blinding studies (i.e., average of $2.3 \% \pm 0.1 \%$ from Table 3-13).

The blinding had reached approximately $6 \%$ after $1305 \mathrm{~kg}$ of material had been screened and was increasing at an average of approximately $0.7 \%$ for each $290 \mathrm{~kg}$ screened thereafter. This gradual buildup in blinding 
TABLE $3-12$

LEAD ANGLE COMPARISONS FROM UNIFRAME SCREENER EFFICIENCY STUDIES

\begin{tabular}{|c|c|c|c|c|c|c|}
\hline $\begin{array}{l}\text { Lead Angle } \\
\text { (deg) }\end{array}$ & $\begin{array}{l}\text { No. of Bottom } \\
\text { Weights }\end{array}$ & $\operatorname{Charge}^{(\mathrm{a})}$ & $\begin{array}{l}\text { Material } \\
\text { in Oversize } \\
\text { Crusher } \\
(\mathrm{kg})\end{array}$ & $\begin{array}{l}\text { Percent } \\
\quad \text { in } \\
\text { Oversize } \\
\text { Crusher }\end{array}$ & $\begin{array}{l}\text { Percent } \\
\text { Through } \\
\text { Screener } \\
\text { (Efficiency) }\end{array}$ & $\Delta$ Efficiency \\
\hline 35 & 2 & 145 & 8.6 & 5.9 & 94.1 & - \\
\hline 45 & 2 & 145 & 8.1 & 5.6 & 94.4 & 0.4 \\
\hline 55 & 2 & 145 & 7.2 & 5.0 & 95.0 & 0.6 \\
\hline 65 & 2 & 145 & 4.9 & 3.4 & 96.6 & 1.6 \\
\hline \multicolumn{7}{|c|}{ With One Bottom Weight Removed } \\
\hline 55 & 2 & 145 & 7.2 & 5.0 & 95.0 & -- \\
\hline 55 & 1 & 145 & 3.6 & 2.5 & 97.5 & 2.5 \\
\hline 65 & 2 & 145 & 4.9 & 3.4 & 96.6 & -- \\
\hline 65 & 1 & 145 & 1.7 & 1.2 & 98.8 & 2.2 \\
\hline
\end{tabular}

(a) $100 \% ;-4750-\mu m$ mesh size material. 
TABLE 3-13

SCREENER BLINDING STUDIES

(4760- m Wire Mesh Screen, $55^{\circ}$ Lead Angle, One Bottom Weight)

\begin{tabular}{|c|c|c|c|c|c|c|c|}
\hline $\begin{array}{c}\text { Charge }^{(a)} \\
\text { (kg) }\end{array}$ & $\begin{array}{l}\text { Material } \\
\text { in Oversize } \\
\text { Crusher } \\
(\mathrm{kg})\end{array}$ & $\begin{array}{l}\text { Percent } \\
\quad \text { in } \\
\text { Oversize } \\
\text { Crusher }\end{array}$ & $\begin{array}{l}\text { Percent } \\
\text { Through } \\
\text { Screener } \\
\text { (Efficiency) }\end{array}$ & $\begin{array}{l}\text { Total } \\
\text { Throughput } \\
\text { (kg) }\end{array}$ & $\begin{array}{c}\text { Blinded } \\
\text { Holes } \\
\text { (One Quadrant) }\end{array}$ & $\begin{array}{l}\text { Est. } \\
\text { Percent } \\
\text { Blinded }\end{array}$ & $\begin{array}{c}\Delta \\
\text { Percent } \\
\text { Blinded }\end{array}$ \\
\hline
\end{tabular}

(a) $100 \% ;-5513-\mu \mathrm{m}$ mesh size material. 
could be expected to produce the same inefficiency of screening and required maintenance as the perforated plate, except over a longer period of time. To avoid this eventuality, a commercially available screener self-cleaning device was purchased and installed for testing (Fig. 3-19). This device consists of a perforated plate with holes large enough to prevent blinding $(1.9-\mathrm{cm}$ diameter). The plate is mounted beneath the mesh screen to support hollow nylon cylindrical sliders $(6.35-\mathrm{cm}$ diameter, $0.318-\mathrm{cm}$ wall, $1.9 \mathrm{~cm}$ length) which bounce and rotate in the space between the plate and the screen to dislodge particles. The additional weight and dynamics of the self-cleaning device necessitated changing the motion generator settings to those recommended by the manufacturer (i.e., 70-deg lead angle with two bottom weights). The increase in lead angle offset the efficiency loss by the addition of a weight, as shown in later tests, but resulted in some material holdup.

Tests were conducted to establish the ability of the self-cleaning device to minimize blinding and to determine the effect of the new motion generator settings on screening efficiency (Table 3-14). Blinding was reduced to a few particles on the entire screen after $435 \mathrm{~kg}$ throughput. The increase in blinding per $290 \mathrm{~kg}$ of throughput was reduced to $0.01 \%$ with the self-cleaning device from the previously observed average of $0.7 \%$ (Table 3-13) without the device. In all previous tests the material had been charged to the screen through a 5-cm-diameter pipe located $7.6 \mathrm{~cm}$ above the screen surface. To simulate the effects of the tertiary crusher discharge chute on screenings, the material was charged through a chute (30 $\mathrm{cm}$ long $\times 7.6 \mathrm{~cm}$ wide) 1ocated $60 \mathrm{~cm}$ above the screen surface for the remaining tests. The effect of the chute on blinding was too insignificant to discern; however, the chute feeding did result in a slightly lower screener efficiency than was observed in either of the two previous identical tests with pipe feeding ( $97.2 \%$ versus $97.7 \%$ and $97.5 \%$ ) (Table $3-14$ ). This effect was attributed to a reduction in screen surface area exposure to that portion of material charged farthest from the center of the screen. 
TABLE 3-14

SCREENER SELF-CLEANING STUDIES

(4760- $\mu \mathrm{m}$ Wire Mesh Screen, $70^{\circ}$ Lead Angle, Two Bottom Weights)

\begin{tabular}{|c|c|c|c|c|c|c|c|}
\hline $\begin{array}{c}\text { Charge } \\
(\mathrm{kg})\end{array}$ & $\begin{array}{l}\text { Material } \\
\text { in Oversize } \\
\text { Crusher } \\
(\mathrm{kg})\end{array}$ & $\begin{array}{l}\text { Percent } \\
\text { in } \\
\text { Oversize } \\
\text { Crusher }\end{array}$ & $\begin{array}{c}\text { Percent } \\
\text { Through } \\
\text { Screener } \\
\text { (Efficiency) }\end{array}$ & $\begin{array}{l}\text { Total } \\
\text { Throughput } \\
\text { (kg) }\end{array}$ & $\begin{array}{c}\text { Blinded } \\
\text { Holes } \\
\text { (Entire Screen) }\end{array}$ & $\begin{array}{l}\text { Est. } \\
\text { Percent } \\
\text { Blinded }\end{array}$ & $\begin{array}{c}\Delta \\
\text { Percent } \\
\text { Blinded }\end{array}$ \\
\hline $\begin{array}{l}145 \\
145\end{array}$ & $\begin{array}{l}3.3 \\
3.6\end{array}$ & $\begin{array}{l}2.3 \\
2.5\end{array}$ & $\begin{array}{l}97.7 \\
97.5\end{array}$ & $\begin{array}{l}145 \\
290\end{array}$ & $\begin{array}{l}3 \\
4\end{array}$ & $\begin{array}{l}0.03 \\
0.04\end{array}$ & 0.01 \\
\hline
\end{tabular}

With Simulated Tertiary Crusher Discharge Chute

$\stackrel{w}{\stackrel{w}{*}}$

\begin{tabular}{l|l|l|l|l|l|l|l|l|l|}
145 & 4.1 & 2.8 & 97.2 & 435 & 0.05 \\
\hline
\end{tabular}

(a) $100 \%$; $-5513-\mu \mathrm{m}$ mesh size material. 
Screener tests were continued using actual product from the UNIFRAME tertiary crusher tests (Table 3-15). The initial use of this material (test ST-A) demonstrated a marked decrease in screening efficiency compared with the results from $100 \%,-4750-\mu \mathrm{m}$ material under the same test conditions ( $97.2 \%$ to $94.3 \%$ efficiency); blinding was also increased.

One of the motion generator bottom weights was removed for the second test (ST-B) with tertiary crusher product, and efficiency was improved by $1 \%$ to $95.3 \%$. The particles showed a tendency to migrate toward the center of the screen at these motion generator settings. This contributes to holdup increase and blinding by allowing a longer time period for the marginal size particles to become lodged in an opening instead of rapidly discharging to the oversize crusher.

In the third test $(\mathrm{VC}-37)$, the efficiency decreased to $92.0 \%$. Because efficiencies were not consistently above the desired $95 \%$, which would assure limitation of oversize crushing of acceptable material to $<5 \%$, it was decided to investigate the screening characteristics of a $6350-\mu \mathrm{m}$ wire mesh screen. As expected, the screening efficiency was increased and blinding and holdup were decreased with the 6350- $\mu \mathrm{m}$ mesh screen because the tertiary crusher product contained fewer particles in this size range (Table 3-16). Although the effect of using a 6350-um screen would be to greatly reduce the quantity of acceptable material which was unnecessarily recrushed in the oversize crusher, it would also allow some of the unacceptable product (i.e., $>4750 \mu \mathrm{m}$ ) to pass through the screen. An estimate of this quantity was obtained from test VC-38 (Table 3-17). In this run, $1.98 \mathrm{wt} \%$ of the screened product was greater than $4750 \mu \mathrm{m}$ and $80.8 \%$ of that material ( 1.60 wt \% of the screened product) passed through the screen. Considerable breakup of the particle occurred during screening and transport, as evidenced by decrease in the $+6350-\mu \mathrm{m}$ material from $1.44 \mathrm{wt} \%$ in the feed to $0.34 \mathrm{wt} \%$ in the product (Table 3-17).

A product very close to the desired primary burner feed size distribution (Fig. 3-20) resulted from calculation of the expected UNIFRAME system crughed product size distribution using the average tertiary crusher 
TABLE $3-15$

SCREENER TESTS WITH TERTIARY CRUSHER PRODUCT

(4750-um Wire Mesh Screen)

\begin{tabular}{l|l|l|l}
\hline \multicolumn{1}{c|}{ Test No. } & ST-A & ST-B & VC-37 \\
\hline Lead ang1e (degrees) & 70 & 70 & 70 \\
No. bottom weights & 2 & 1 & 1 \\
B1inded holes (entire screen) & 14 & 43 & 73 \\
Estimated percent blinded & 0.1 & 0.4 & 0.6 \\
Holdup on screen (kg) & 0.021 & 0.138 & 0.130 \\
Holdup (\%) & 0.04 & 0.28 & 0.32 \\
-4750- $\mu m$ material in oversize crusher (kg) & 2.827 & 2.402 & 3.232 \\
-4750- $\mu m$ material in oversize crusher (\%) & 5.7 & 4.7 & 8.0 \\
Screening efficiency (\%) & 94.3 & 95.3 & 92.0 \\
Feed material (tertiary test No.) & TC-27 & TC-27 & TC-25 \\
\hline
\end{tabular}


TABLE $3-16$

SCREENER TESTS WITH TERTIARY CRUSHER PRODUCT (6350-um Wire Mesh Screen)

\begin{tabular}{|c|c|c|c|}
\hline Test No. & VC $-37 \mathrm{~B}$ & $\mathrm{ST}-\mathrm{C}$ & $S T-D$ \\
\hline Lead angle (degrees) & 70 & 70 & 70 \\
\hline No, bottom weights & 2 & 1 & 2 \\
\hline Blinded holes (entire screen) & 2 & 9 & 1 \\
\hline Estimated percent blinded & 0.02 & 0.08 & 0.01 \\
\hline Holdup on screen $(\mathrm{kg})$ & 0.041 & 0.031 & 0.026 \\
\hline Holdup (\%) & 0.10 & 0.06 & 0.05 \\
\hline$-4750-\mu$ material in oversize crusher $(\mathrm{kg})$ & 0.026 & 0.038 & 0.040 \\
\hline$-4750-\mu \mathrm{m}$ material in oversize crusher $(\%)$ & 0.1 & 0.1 & 0.1 \\
\hline Screening efficiency (\%) & 99.9 & 99.9 & 99.9 \\
\hline Feed material (tertiary test No.) & $\mathrm{TC}-25$ & $\mathrm{TC}-27$ & TC-27 \\
\hline
\end{tabular}


TABLE $3-17$

SCREENER TEST VC-38 WITH TERTIARY CRUSHER PRODUCT

(6350- $\mu \mathrm{m}$ Wire Mesh Screen)

\author{
Product From \\ Tertiary Crusher \\ Test TC-28 \\ (wt \%)
}

Feed

$+6350 \mu \mathrm{m}$

$-6350 \mu \mathrm{m}+4760 \mu \mathrm{m}$

1.44

$-4750 \mu \mathrm{m}$

0.88

Tota1

$\frac{97.68}{100.00}$

Screened Product

Left on Screen

$+6350 \mu \mathrm{m}$

$-6350 \mu \mathrm{m}+4760 \mu \mathrm{m}$

0.07

$-4750 \mu \mathrm{m}$

0

Tota1

0

0.07

Discharged to

Oversize Crusher

$+6350 \mu \mathrm{m}$

0.27

$-6350 \mu \mathrm{m}+4760 \mu \mathrm{m}$

0.04

$-4750 \mu \mathrm{m}$

$\frac{0.04}{0.35}$

Total

Passed Through Screen

$\begin{array}{lr}+6350 \mu \mathrm{m} & 0 \\ -6350 \mu \mathrm{m}+4760 \mu \mathrm{m} & 1.60 \\ -4750 \mu \mathrm{m} & \frac{97.98}{99.58} \\ \text { Total } & \end{array}$

Screened Product Totals

$\begin{array}{lr}+6350 \mu \mathrm{m} & 0.34 \\ -6350 \mu \mathrm{m}+4760 \mu \mathrm{m} & 1.64 \\ -4750 \mu \mathrm{m} & 98.02 \\ \text { Total } & 100.00\end{array}$




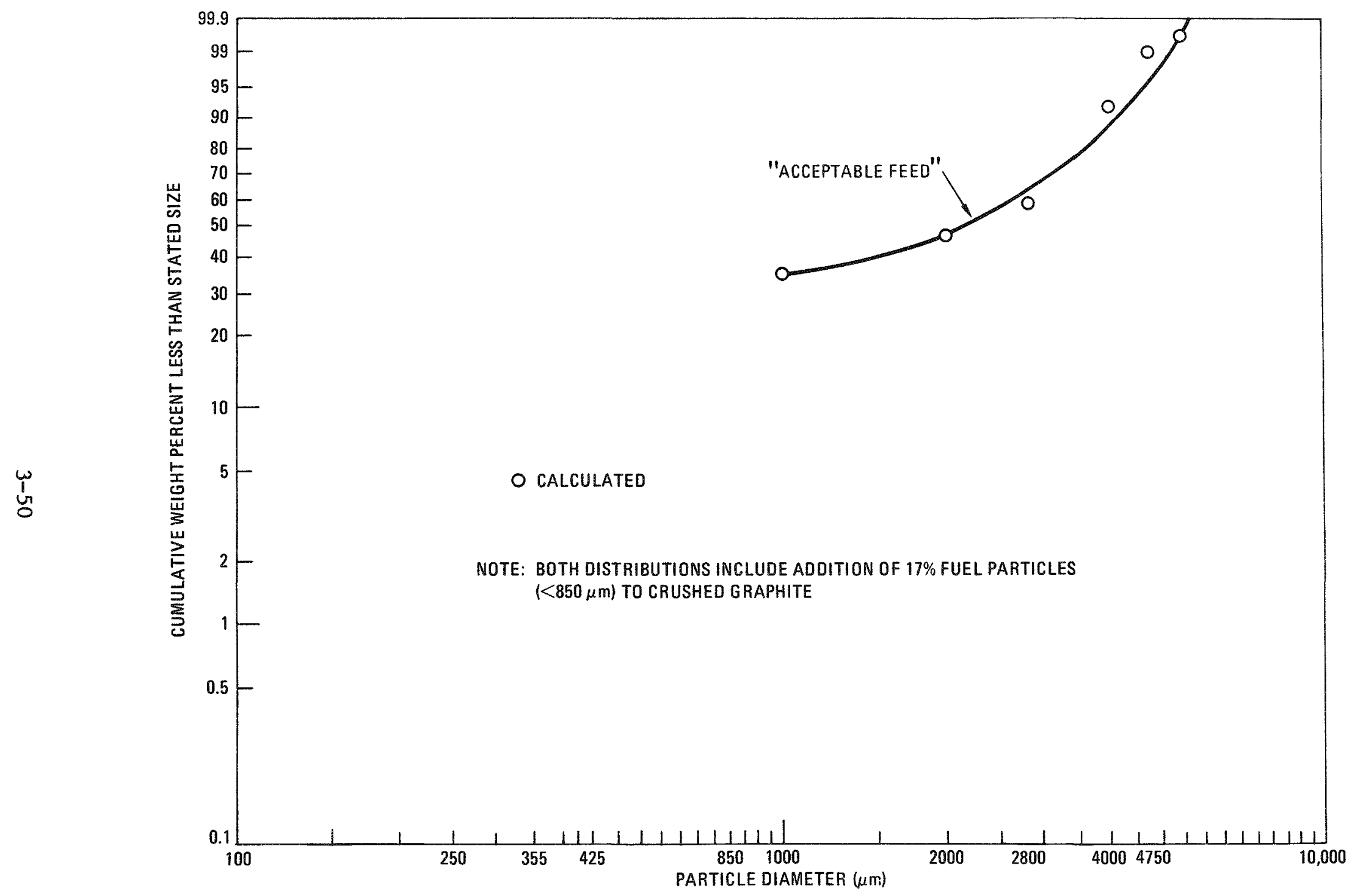

Fig. 3-20. Calculated UNIFRAME system crushed product distribution versus primary burner "acceptable feed" distribution 
product size distribution (tests $\mathrm{TC}-26$ through $\mathrm{TC}-28$ and $\mathrm{TC}-31$ through TC-33), assuming that it was screened through a 4750- $\mu \mathrm{m}$ screen (average results of tests $\mathrm{ST}-\mathrm{A}, \mathrm{ST}-\mathrm{B}$, and $\mathrm{VC}-37$ ) and the oversize discharge was recrushed in the oversize crusher (average results of tests $\mathrm{OP}-\mathrm{C}$ and $\mathrm{OC}-43$ through OC-45). The 6350- $\mu \mathrm{m}$ screen test results demonstrated that an insufficient quantity of material would be discharged to the oversize crusher $(0.35 \mathrm{wt} \%$ in test $\mathrm{VC}-38$, Table 3-17) to achieve the final desired product size distribution. It was decided to complete the screener tests with the 4750- $\mu \mathrm{m}$ screen and to accept the inefficiency until future planned testing of the UNIFRAME as a system demonstrates actual product size distributions. The results of screening a half-size fuel element, a full-size fuel element, and a half-size control rod element after crushing in the first three stage of the UNIFRAME system are compared in Table 3-18.

The total screening time in all tests was $15 \mathrm{~min}$; however, the majority of the screening was completed shortly after each charge was complete, and the operation was continued solely to determine the quantity of material holdup left on the screen at the end of the time allotted for processing a fuel element. Holdup varied from a $10 \mathrm{w}$ of $0.3 \%$ to a high of $0.6 \%$, and screener blinding varied from $0.6 \%$ to $1.0 \%$ of the total openings. The efficiency varied from a 10w of $88.6 \%$ with a full-size element to $98.5 \%$ with a half-size control rod element. Flooding of the screen due to the rapid charging rate contributed to lowering the efficiency in the full-size element tests. In a previous test (ST-B, Table 3-15) which had screening conditions identical to those of VC-37 with material from crushing a halfsize fuel element, spreads of $0.2 \%, 0.04 \%$, and $3.3 \%$ were observed in the results from blinding, holdup, and efficiency, respectively. With the data obtained to date, it is difficult to ascertain if the differences between half-size fuel elements, full-size fuel elements, and half-size control rod elements are significant enough to produce variability in the screening of their crushed products.

To demonstrate the ability of the screener to start under loaded conditions and to establish the potential effects of these conditions on 
TABLE $3-18$

UNIFRAME SCREENER PHASE I TESTS WITH HALF-SIZE FUEL ELEMENT,

FULL-SIZE FUEL ELEMENT, AND HALF-SIZE CONTROL ROD ELEMENT

(4750- $\mu \mathrm{m}$ Mesh Screen, Motion Generator $70^{\circ}$ Lead Angle, One Bottom Weight)

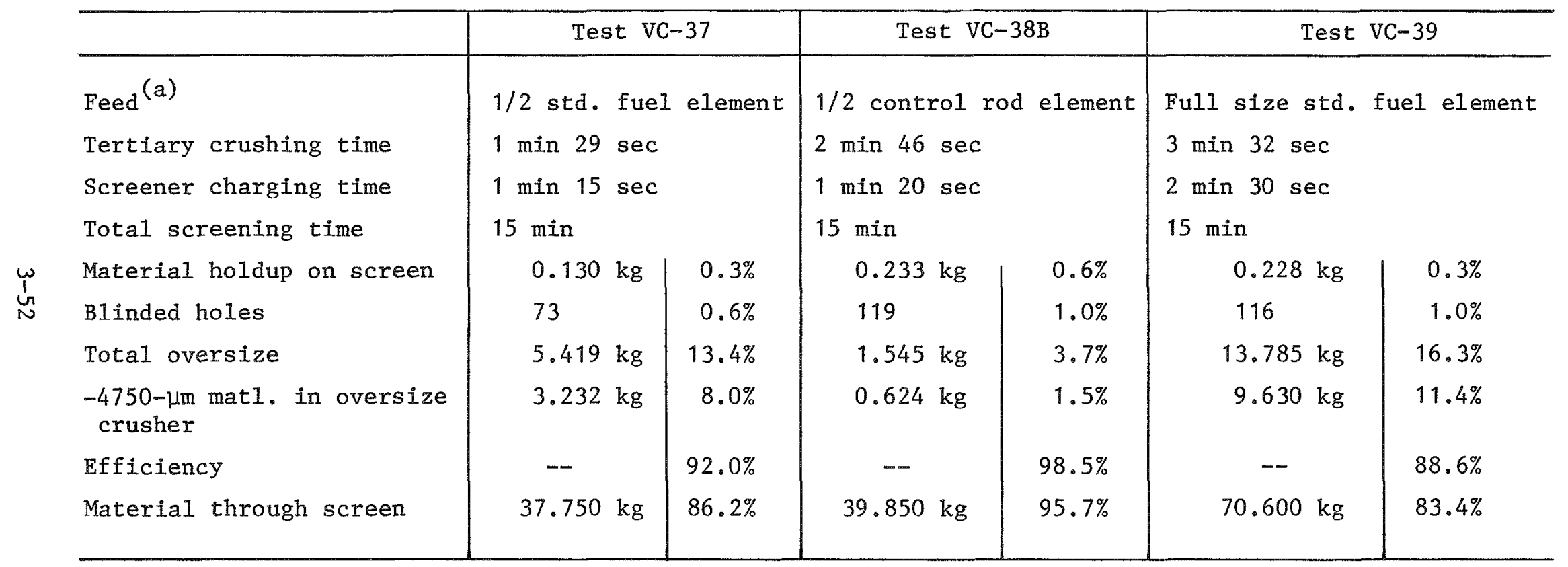

(a) After primary, secondary, and tertiary crushing. 
subsequent equipment, the screener was started after charging an entire crushed half-size fuel element and again after charging an entire crushed full-size fuel element. In each case, after charging and prior to starting the screener, the material that discharged through the screener, either through the mesh screen or by overflowing the screening table, was weighed and characterized, and the material discharged through the oversize chute was similarly treated. The screener was then started and operated for 15 min, and the screener and oversize discharges were again weighed and characterized. These results are summarized in Table $3-19$.

The material which passed through the screener prior to start-up was $5.1 \%$ of the total weight of the crushed half-size fuel element and increased to $7.1 \%$ of the full-size fuel element. This was the obvious result of additional overflow of the screening table from the increased charge. Although only a small quantity of material (0.1\%) discharged through the oversize chute prior to start-up with the half-size element, a reasonably large percentage (13.1\%) discharged through the oversize chute with the full-size element. The difference is attributable to the larger charge.

In both tests the screener started up without difficulty and was accompanied by unscreened material discharging over the screening table and through the oversize discharge chute. Under these conditions, the material which discharged through the oversize chute was a larger percentage in the half-size element test $(32.1 \%)$ than in the full-size element test $(6.0 \%)$. The large oversize discharge during charging and the large quantity of material which discharged over the screening table after start-up in the full-size element test contributed to equalization of the total quantity of material which discharged through the oversize chute for both sizes of elements (i.e., $13.601 \mathrm{~kg}$ for the half-size element and $16.200 \mathrm{~kg}$ for the ful1-size element).

These tests demonstrated that in the event that it becomes necessary to start the screener under loaded conditions, (1) the oversize crusher 
TABLE $3-19$

UNIFRAME SCREENER PHASE I TESTS (START-UNDER-LOAD)

(4750- $\mu \mathrm{m}$ Mesh Screen, Motion Generator $70^{\circ}$ Lead Angle, One Bottom Weight)

\begin{tabular}{|c|c|c|c|c|c|}
\hline & \multicolumn{3}{|c|}{ Test VC-40 } & \multicolumn{2}{|c|}{ Test VC-42 } \\
\hline $\begin{array}{l}\text { Feed } \\
\text { Prior to Startup }\end{array}$ & $\begin{array}{r}1 / 2 \text { std. } \mathrm{f} \\
2.208 \mathrm{k}\end{array}$ & $\begin{array}{l}\text { fuel } \\
\mathrm{kg}\end{array}$ & $\begin{array}{l}\text { element } \\
5.2 \%\end{array}$ & $\begin{array}{c}\text { Full-size std. } \\
17.127 \mathrm{~kg}\end{array}$ & $\begin{array}{l}\text { fuel element } \\
20.2 \%\end{array}$ \\
\hline $\begin{array}{l}\text { Material through screener } \\
\quad+4750 \mu \mathrm{m} \\
\quad-4750 \mu \mathrm{m}\end{array}$ & $\begin{array}{l}2.155 \mathrm{k} \\
0.006 \mathrm{k} \\
2.149 \mathrm{k}\end{array}$ & $\begin{array}{l}\mathrm{kg} \\
\mathrm{kg} \\
\mathrm{kg}\end{array}$ & $\begin{array}{r}5.1 \% \\
<0.1 \% \\
5.1 \%\end{array}$ & $\begin{array}{l}5.982 \mathrm{~kg} \\
0.675 \mathrm{~kg} \\
5.307 \mathrm{~kg}\end{array}$ & $\begin{array}{l}7.1 \% \\
0.8 \% \\
6.3 \%\end{array}$ \\
\hline $\begin{array}{l}\text { Material to oversize } \\
\quad+4750 \mu \mathrm{m} \\
-4750 \mu \mathrm{m}\end{array}$ & $\begin{array}{l}0.053 \mathrm{k} \\
0.007 \mathrm{k} \\
0.046 \mathrm{k}\end{array}$ & $\begin{array}{l}\mathrm{kg} \\
\mathrm{kg} \\
\mathrm{kg}\end{array}$ & $\begin{array}{r}0.1 \% \\
<0.1 \% \\
0.1 \%\end{array}$ & $\begin{array}{r}11.145 \mathrm{~kg} \\
0.917 \mathrm{~kg} \\
10.228 \mathrm{~kg}\end{array}$ & $\begin{array}{r}13.1 \% \\
1.1 \% \\
12.0 \%\end{array}$ \\
\hline During 15-Min Screening & $39.945 \mathrm{k}$ & $\mathrm{kg}$ & $94.5 \%$ & $67.542 \mathrm{~kg}$ & $79.6 \%$ \\
\hline $\begin{array}{l}\text { Material through screener } \\
\quad+4750 \mu \mathrm{m} \\
-4750 \mu \mathrm{m}\end{array}$ & $\begin{array}{r}26.397 \mathrm{k} \\
0.147 \mathrm{k} \\
26.250 \mathrm{k}\end{array}$ & $\begin{array}{l}\mathrm{kg} \\
\mathrm{kg} \\
\mathrm{kg}\end{array}$ & $\begin{array}{r}62.4 \% \\
0.3 \% \\
62.1 \%\end{array}$ & $\begin{array}{r}62.487 \mathrm{~kg} \\
1.237 \mathrm{~kg} \\
61.250 \mathrm{~kg}\end{array}$ & $\begin{array}{r}73.6 \% \\
1.4 \% \\
72.2 \%\end{array}$ \\
\hline $\begin{array}{l}\text { Material to oversize } \\
\quad+4750 \mu \mathrm{m} \\
-4750 \mu \mathrm{m}\end{array}$ & $\begin{array}{r}13.548 \mathrm{k} \\
0.586 \mathrm{k} \\
12.962 \mathrm{k}\end{array}$ & $\begin{array}{l}\mathrm{kg} \\
\mathrm{kg} \\
\mathrm{kg}\end{array}$ & $\begin{array}{r}32.1 \% \\
1.4 \% \\
30.7 \%\end{array}$ & $\begin{array}{l}5.055 \mathrm{~kg} \\
0.335 \mathrm{~kg} \\
4.720 \mathrm{~kg}\end{array}$ & $\begin{array}{l}6.0 \% \\
0.4 \% \\
5.6 \%\end{array}$ \\
\hline Totals & $42.274 \mathrm{k}$ & $\mathrm{kg}$ & $100 \%$ & $84.810 \mathrm{~kg}$ & $100 \%$ \\
\hline Material Hold-up on Screen & $0.121 \mathrm{k}$ & $\mathrm{kg}$ & $0.3 \%$ & $0.141 \mathrm{~kg}$ & $0.2 \%$ \\
\hline Blinded Holes & 42 & & $0.4 \%$ & 71 & $0.6 \%$ \\
\hline $\begin{array}{l}\text { Material Through Screener } \\
\quad+4750 \\
\quad-4750\end{array}$ & $\begin{array}{r}28.552 \mathrm{k} \\
0.153 \mathrm{k} \\
28.399 \mathrm{k}\end{array}$ & $\begin{array}{l}\mathrm{kg} \\
\mathrm{kg} \\
\mathrm{kg}\end{array}$ & $\begin{array}{r}67.5 \% \\
0.3 \% \\
67.2 \%\end{array}$ & $\begin{aligned} 68.469 \mathrm{~kg} \\
1.912 \mathrm{~kg} \\
66.557 \mathrm{~kg}\end{aligned}$ & $\begin{array}{r}80.7 \% \\
2.2 \% \\
78.5 \%\end{array}$ \\
\hline $\begin{array}{l}\text { Material to Oversize } \\
\quad+4750 \\
\quad-4750\end{array}$ & $\begin{array}{rl}13.601 & k \\
0.593 & k \\
13.008 & k\end{array}$ & $\begin{array}{l}\mathrm{kg} \\
\mathrm{kg} \\
\mathrm{kg}\end{array}$ & $\begin{array}{r}32.2 \% \\
1.4 \% \\
30.8 \%\end{array}$ & $\begin{aligned} 16.200 \mathrm{~kg} \\
1.252 \mathrm{~kg} \\
14.948 \mathrm{~kg}\end{aligned}$ & $\begin{array}{r}19.1 \% \\
1.5 \% \\
17.6 \%\end{array}$ \\
\hline
\end{tabular}


will be required to process additional quantities of material, with the potential for excessive fuel particle breakage, and (2) the primary burner feed will contain quantities of unacceptable material which has completely bypassed the screening. In addition, the large quantity of material which rapidly enters the pneumatic transport line at start-up under load tends to place a burden on the transport system.

\subsection{REMOTE HANDLING SYSTEM}

Handling fixtures required to demonstrate remote maintenance capabilities were designed and fabricated for the UNIFRAME system. The lift fixtures for the pitman assemblies and the primary fixed $j$ aw and the shroud shutoff valve have been tested as described below (see Ref. 3-3 for design details).

\subsubsection{Prototype Size Reduction System Component Handling Fixtures}

Tests of the following UNIFRAME jaw handing fixtures have been completed:

1. Lift fixture, primary pitman assembly.

2. Lift fixture, primary fixed $j a w$.

3. Lift fixture, secondary pitman assembly.

These tests included interface checkout and operational verification, which involved mounting of each fixture on its $j$ aw in accordance with operating procedures to verify compatibility of the interfaces. Adjustments were made where necessary, including adjustments of limit switches and other electrical components. Initial operator training and familiarization were performed in conjunction with the checkout tests. All tests were completed satisfactorily, and no significant operational problems were noted. 


\subsubsection{Crusher Shroud Shutoff Valve}

The valve body and the slide valve assambly were fabricated as shown in Fig. 3-21. Interface checkout and functional verification were performed along with initial installation and mounting adjustment. No problems were noted, and the valve performed satisfactorily in all operating modes. Complete operational checkout will be performed later in conjunction with other UNIFRAME testing.

\subsubsection{Secondary Pitman Lift Fixture}

UNIFRAYE checkout operations necessitated the removal of the various jaws for inspection and adjustment purposes. The appropriate lift fixtures were used to aid jaw handling (Fig. 3-22). During the removal of the secondary pitman assembly, the secondary pitman lift fixture was damaged. The damage occurred to the toggle lift hook drive assembly (Fig. 3-23). Since these lift operations were performed after satisfactory completion of fixture checkout, it is not certain why the damage occurred. However, preliminary analysis indicated that the limit switch which controls the upper travel 1imit for the toggle hook was not properly adjusted. It was noted that interface testing had been carried out to adapt the secondary pitman fixture for possible use in handing the primary pitman jaw. These tests involved limit switch adjustments which were not compatible with the functions involving secondary pitman removal. Adjustment of the lower limit switch was confirmed; however, adjustment of the upper limit switch was not. It appears likely that adjustments were made but not noted. When operators later attempted to remove the secondary pitman, the lift fixture was operated based on the assumption that the initial checkout limit switch adjustments had not been disturbed. When the fixture was cycled to raise the toggle to its "up" position for removal, it appeared that the limit switch was not contacted and the drive motor continued to operate beyond its upper limit. Figure 3-24 shows the travel required to contact the upper limit switch prior to motor cutoff. Figures 3-24 and 3-25 show the 

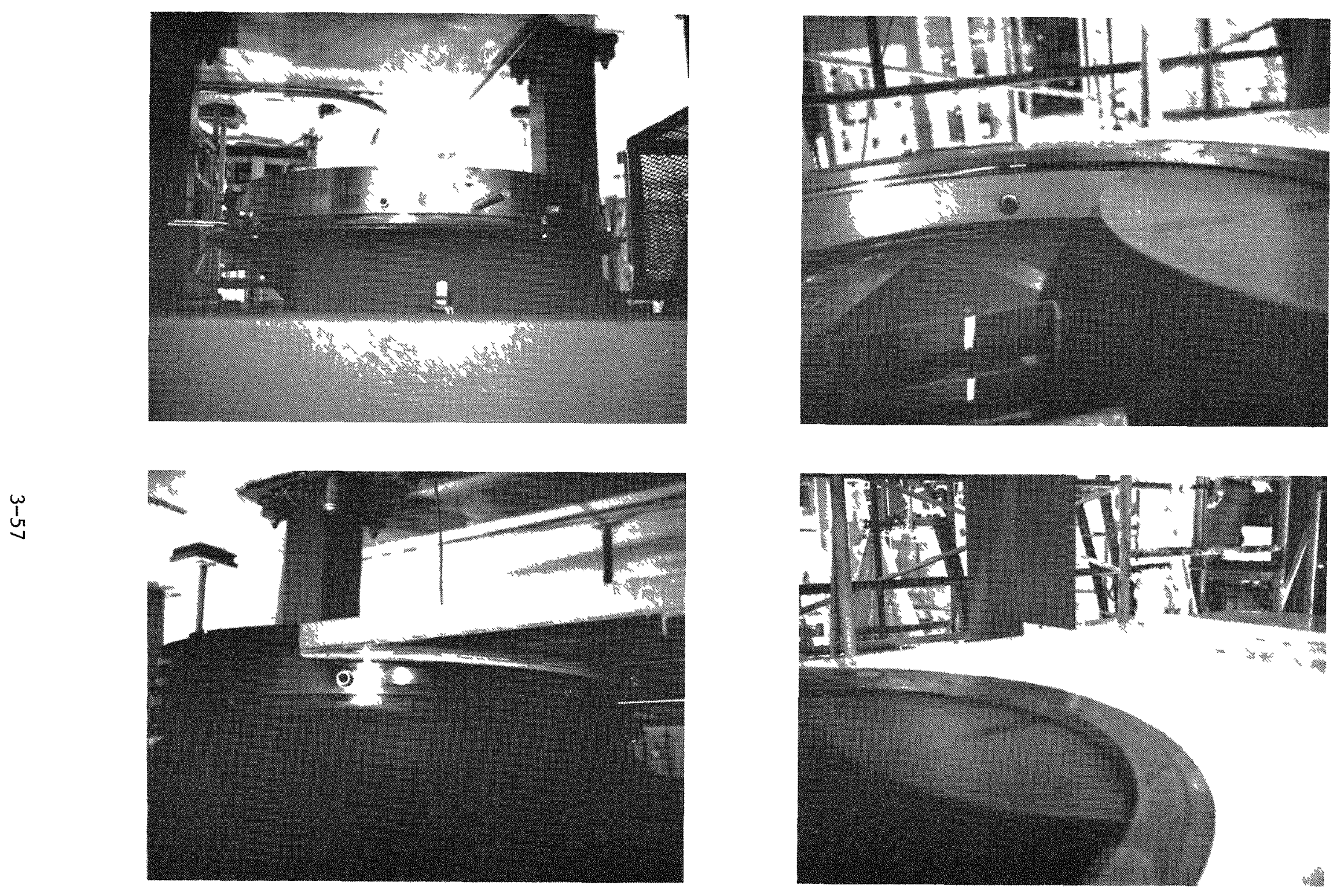

Fig. 3-21. Crusher shroud shutoff valve 


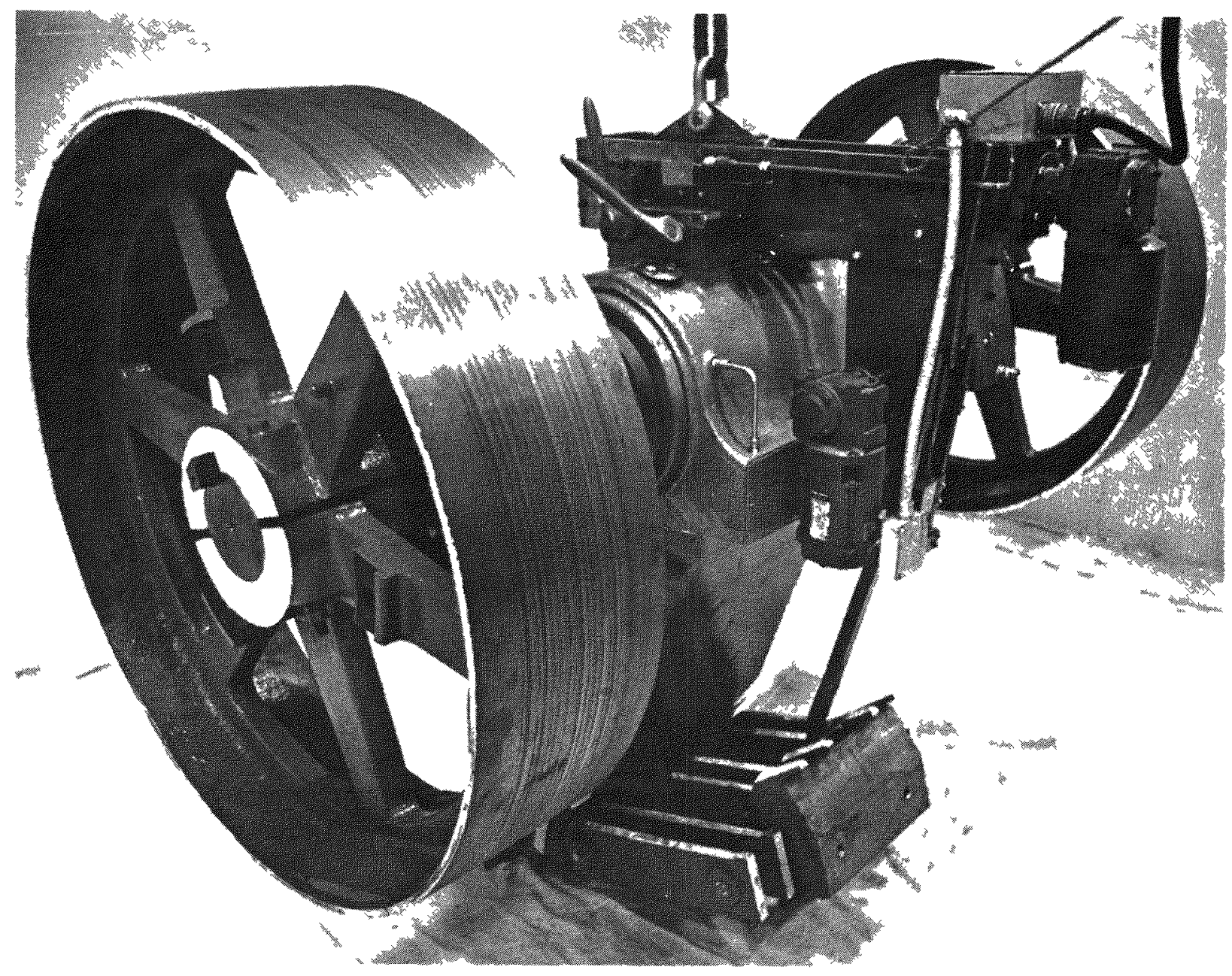

$35-135-200-6 A$

Fig. 3-22. Secondary pitman lift fixture 

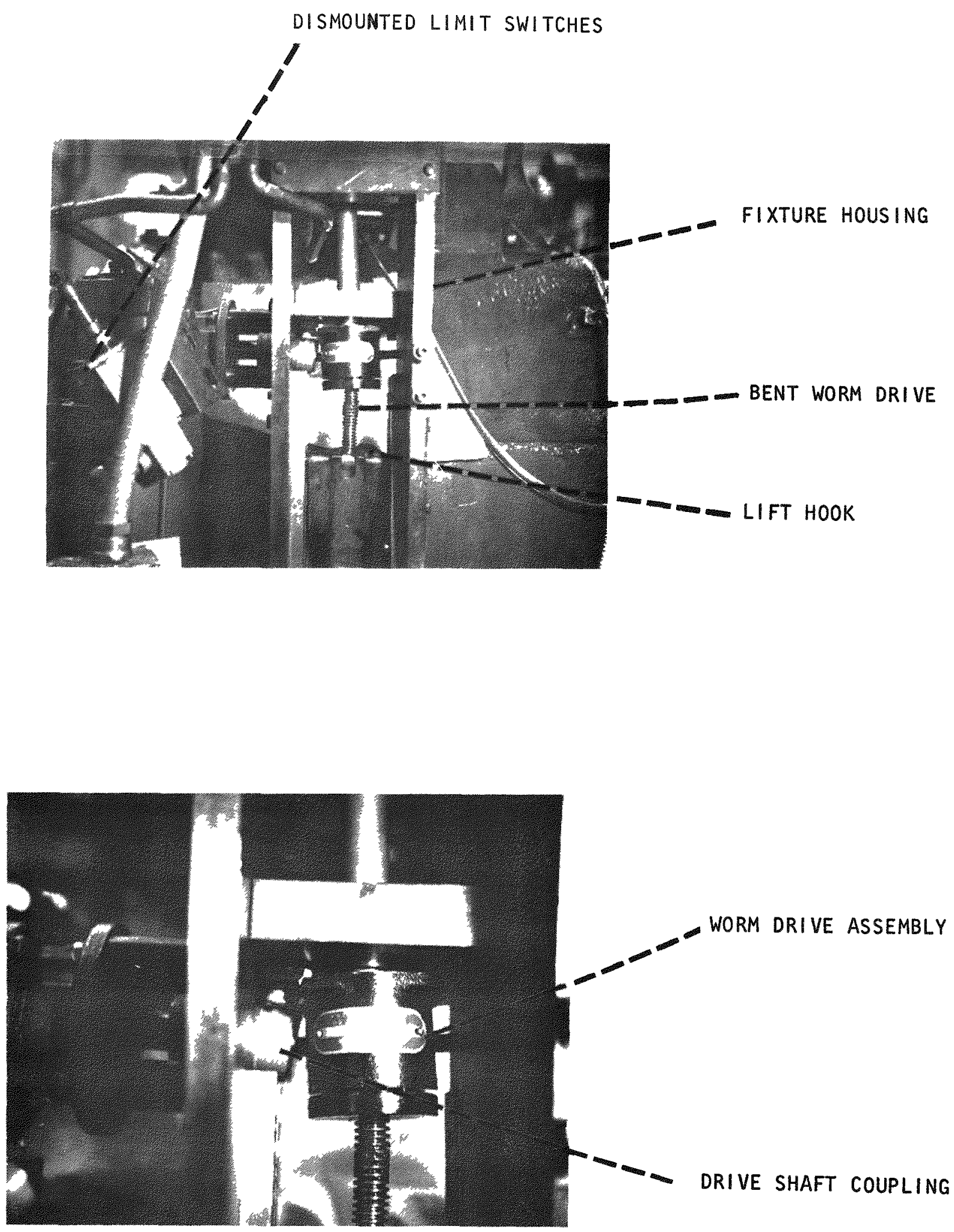

Fig. 3-23. Toggle lift hook drive assembly: secondary pitman lift fixture 


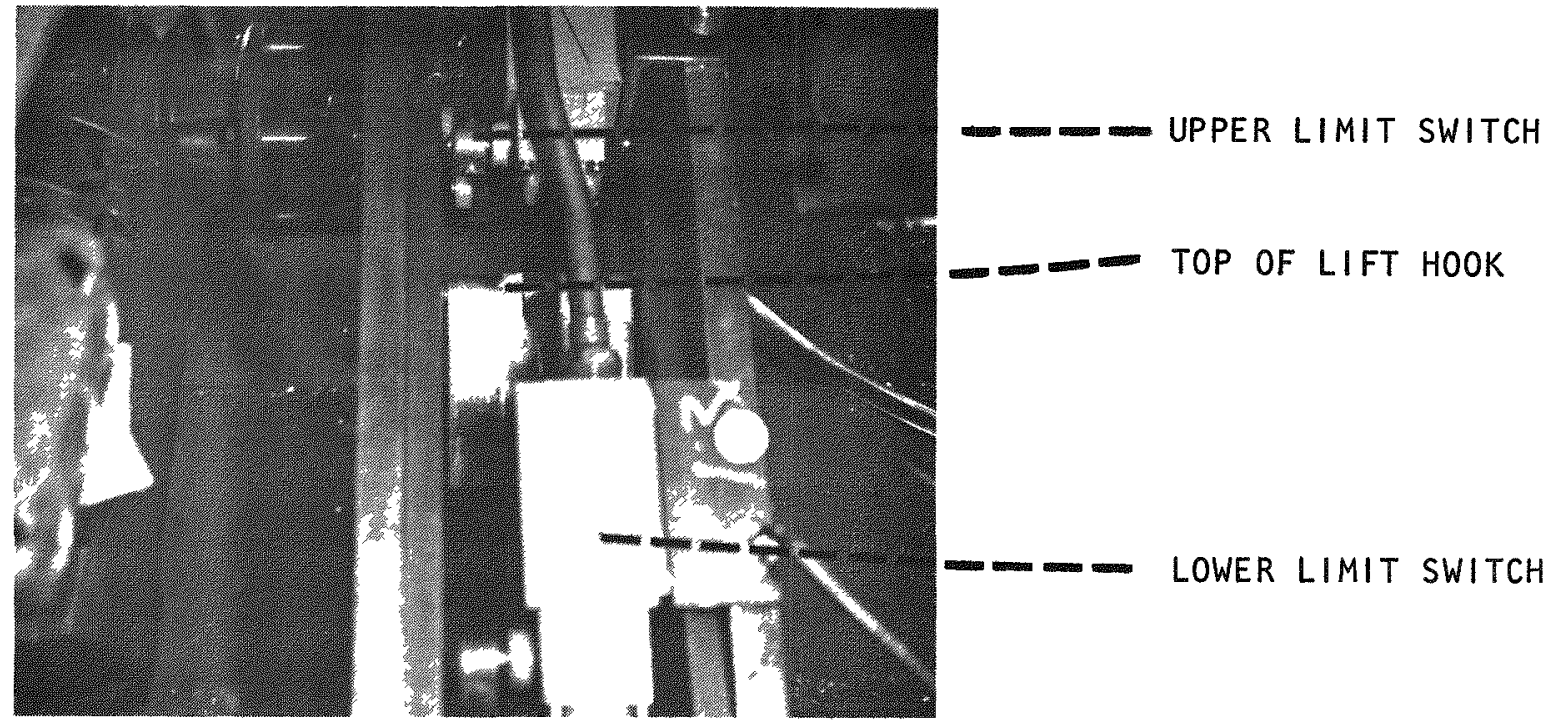

Fig. 3-24. Upper limit switch positioning: secondary pitman lift fixture

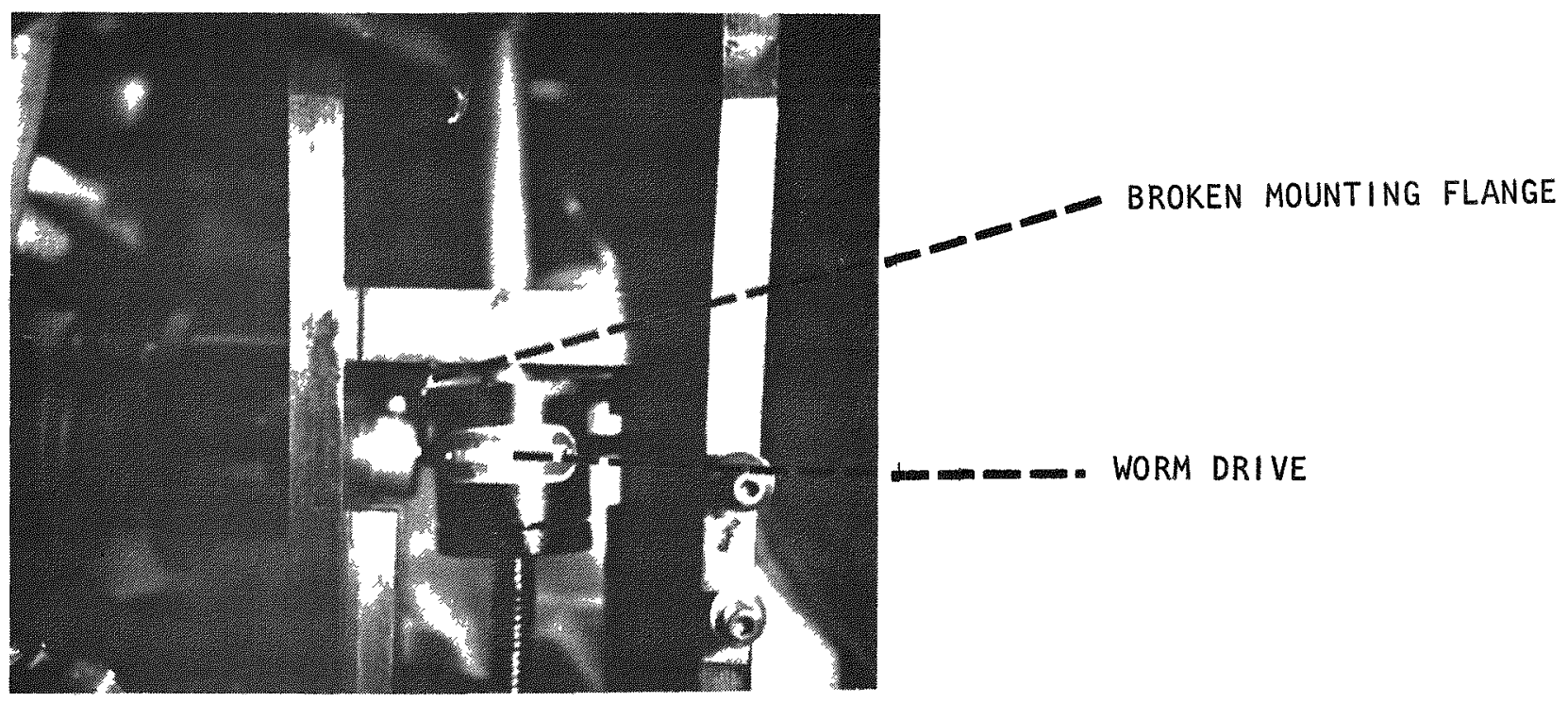

Fig. 3-25. Worm drive assembly: secondary pitman lift fixture 
resulting damage to the worm drive housing and the motor shaft coupling. Figure 3-26 shows that the toggle lift arm broke the temporary lubrication system drain valve, rendering it inoperable. Since the valve is not a prototypical feature and would not normally be used, this is not viewed as a serious condition.

Figure 3-27 shows the relationship of the various components in the failure mode. It can be seen that a direct line of action can be drawn through the drive pivot, hook/pin interface, and toggle pivot. This provides a straight tension load path, which resulted in an overload and subsequent destruction of the hook drive system. The damaged toggle lift hook drive assembly of the secondary pitman lift fixture was repaired, and proper adjustment of the limit switch which controls the maximum upper travel of the toggle hook proved successful; $i_{.}$., damage was avoided, and proper positioning of the hook during reinstallation of the secondary crusher was assured.

During reinstallation of the secondary crusher, the lift fixture failed as a result of pullout of the thrust bearings at the ends of the slide block drive screw. This failure was unrelated to the previous toggle lift hook drive assembly failure; instead, it was result of improper orientation of the thrust bearings. The bearings have been replaced with properly oriented bearings and the fixture is operational. Further evaluation will be performed to

1. Identify specific equipment operation fallures.

2. Identify specific errors in operating procedures or operator performance.

3. Recommend appropriate corrective actions to prevent recurrence of problems. 

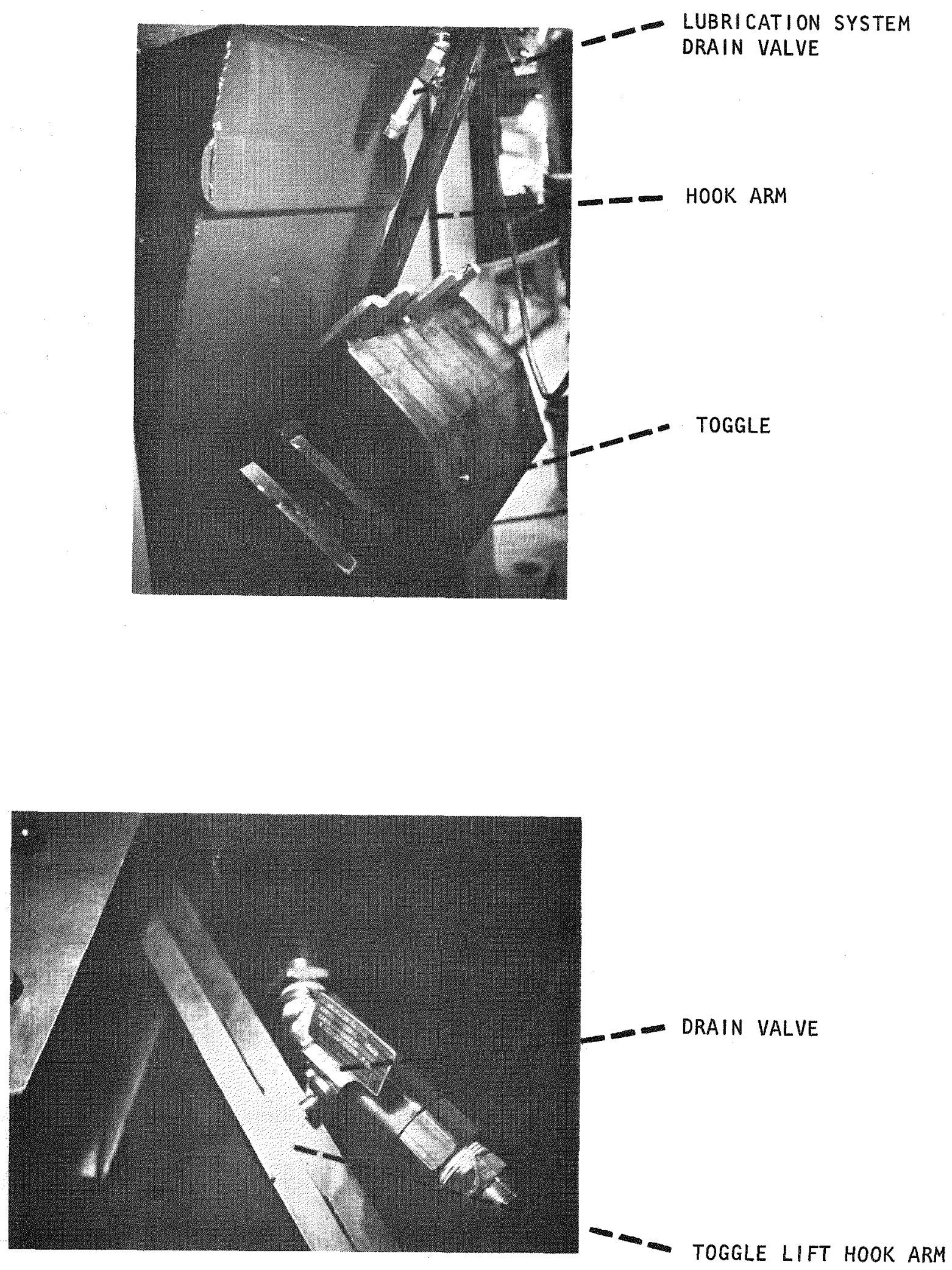

Fig. 3-26. Secondary pitman jaw showing lubrication drain valve damage 


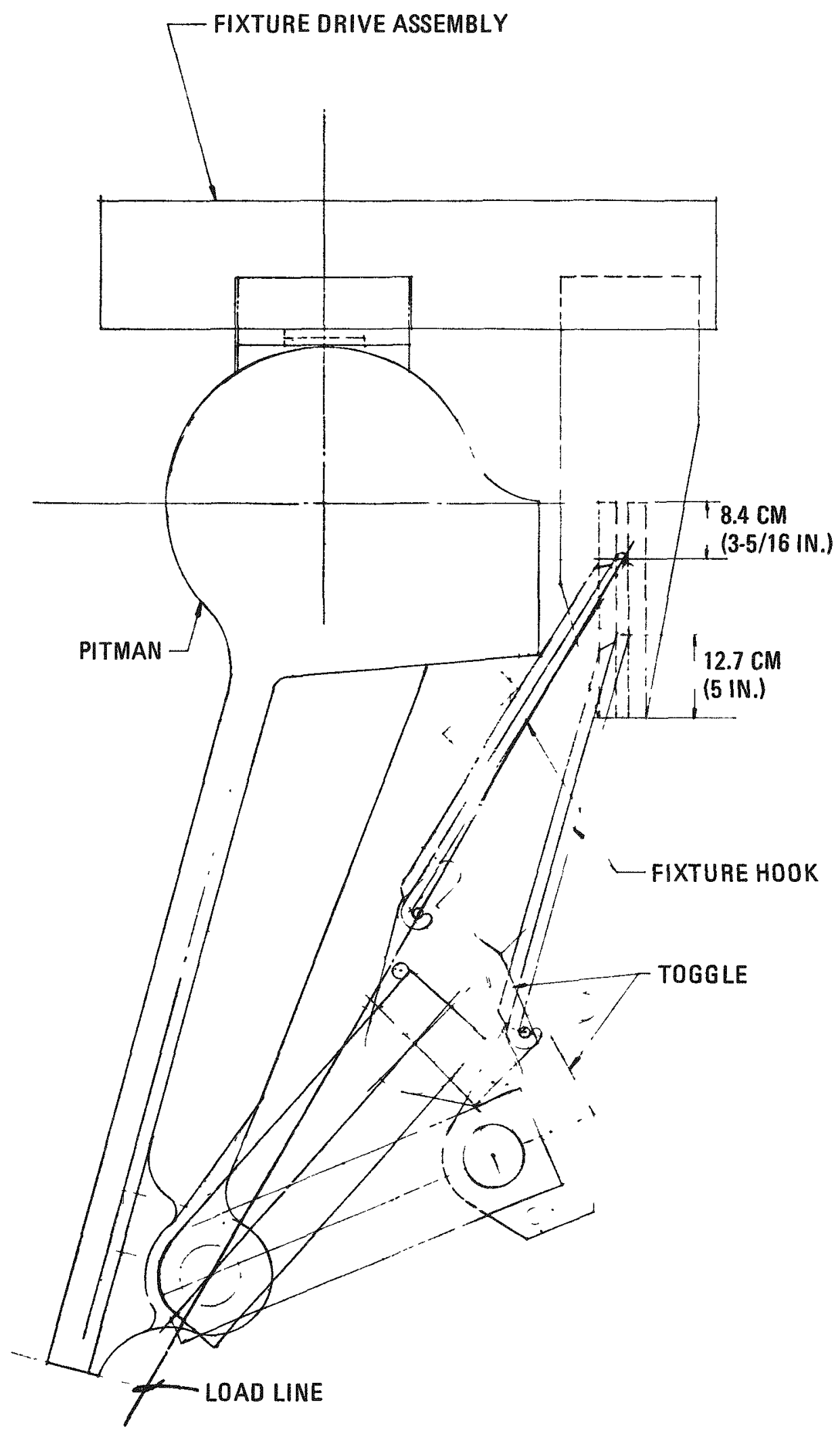

Fig. 3-27. Secondary pitman lift fixture 


\subsection{REFERENCES}

3-1. Baxter, B. J., A. Gasparovic, and A. H. Bond, "Primary Jaw Crusher Development, Interim Report," ERDA Report GA-A12864, General Atomic Company, February 28, 1974.

3-2. Baxter, B. J., et al., "Conceptual Design for a Prototype Fue1 Element Size Reduction System Designated UNIFRAME, Design Status Report," ERDA Report GA-A13275, General Atomic Company, September 1, 1975.

3-3. Ballard, A. S., "Interim Design Status and Operational Report for Semiremote Handling Fixtures: Size Reduction System," ERDA Report GA-A14126, General Atomic Company, February 1977. 


\section{PHASE II: UNIFRAME SYSTEM TESTS WITH UNFUELED ELEMENTS}

\subsection{MODIFIED SECONDARY CRUSHER SHAKEDOWN}

During phase I tests of the secondary crusher, problems with material holdup were encountered, and modifications of the stationary $j$ aw and pitman wear plate designs were necessary. The effectiveness of these modifications in eliminating material holdup was demonstrated during three shakedown tests (SM-1, SM-2, and SM-3) in which the primary, secondary, and tertiary crushers were operated as a system without the screener and oversize crusher. The feed for these tests was partially drilled, unfueled half-length (tests $\mathrm{SM}-1$ and $\mathrm{SM}-2$ ) and full-length (test SM-3) scrap $\mathrm{H}-327$ graphite HTGR fuel elements. The crushed product from each test was separately collected for subsequent screen analysis as it discharged from the tertiary crusher. The entire product from each test was hand screened to determine the quantity of material which was larger than 6350- $\mu \mathrm{m}$ mesh size and the quantity of the $-6350+4750-\mu \mathrm{m}$ mesh-size fraction. The remaining 4750- $\mu \mathrm{m}$ mesh fraction, which constituted the bulk of the material, was split in a 12 to 1 sample splitter to obtain a size sample suitable for determining the size distribution.

The components of the ventilation enclosure at the primary and secondary crusher levels were not installed, and thus the crushing operations and the timing of completion of primary and secondary crushing could be observed. There was no permanent material holdup in any of the three shakedown tests. However, a temporary reduction of the crushing rate occurred in test SM-1 when two fragments rode up and down with the action of the pitman for a short time and then continued to crush to completion. There was no tendency for material holdup in the secondary crusher. A summary of the three shakedown tests is given in Table 4-1. The product 
TABLE 4-1
SUMMARY OF PHASE II TESTS: PRIMARY, SECONDARY, AND TERTIARY CRUSHER SHAKEDOWN (a)

\begin{tabular}{|c|c|c|c|c|}
\hline \multirow{2}{*}{$\begin{array}{l}\text { Test } \\
\text { No. }\end{array}$} & \multirow[b]{2}{*}{ Feed Material } & \multicolumn{3}{|c|}{ Crushing Completion Time } \\
\hline & & Primary & Secondary & Tertiary \\
\hline SM-1 & $\begin{array}{l}\text { Half-1ength H-327 graphite HTGR fuel } \\
\text { element without fuel holes, } \sim 62 \mathrm{~kg}\end{array}$ & $1 \min 5 \mathrm{~s}$ & $3 \min 10 \mathrm{~s}$ & $3 \min 10 \mathrm{~s}$ \\
\hline$S M-2$ & $\begin{array}{l}\text { Half-1ength } \mathrm{H}-327 \text { graphite HTGR fuel } \\
\text { element without fuel holes, } \sim 59 \mathrm{~kg}\end{array}$ & $1 \min 30 \mathrm{~s}$ & $2 \min 50 \mathrm{~s}$ & $2 \min 50 \mathrm{~s}$ \\
\hline$S M-3$ & $\begin{array}{l}\text { Full-length H-327 graphite HTGR fuel } \\
\text { element, fully drilled in one half } \\
\text { and only partial coolant holes in } \\
\text { other half, } 2110 \mathrm{~kg}\end{array}$ & $11 \min 5 \mathrm{~s}$ & $19 \min 48 \mathrm{~s}$ & $19 \min 48 \mathrm{~s}$ \\
\hline
\end{tabular}

(a) Primary crusher $\mathrm{CSS}=5.30 \mathrm{~cm}$, nip angle $=14 \mathrm{deg}$; secondary crusher CSS $-0.64 \mathrm{~cm}$; tertiary crusher gap $=0.27 \mathrm{~cm}$. 
size distribution data, shown in Table 4-2, were used to estimate the change in the product size distribution effected by the screener and oversize crusher.

\subsection{SYSTEM SHAKEDOWN}

The screener and oversize crusher were installed, and two shakedown tests (SM-3 and SM-4) were performed to examine the operation of the UNIFRAME as a system. The feed for these tests was a partially drilled (test SM-4) and a fully drilled (test SM-5) half-length H-327 graphite HTGR fuel element. The crushed products from the screener and oversize crusher were separately collected during each test. The components of the ventilation enclosure at the primary and secondary crusher levels remained off to permit observation of the crushing operations and timing of the completion of primary and secondary crushing.

Permanent material holdup was not observed in either shakedown test. However, a temporary reduction in the crushing rate occurred in test SM-4 when two interlocked fragments in the secondary crusher formed a bridge which continued to be chipped and worn until crushing was completed. A temporary reduction in the crushing rate occurred in test SM-5 because of a single fragment in the primary crusher which behaved in a similar manner as observed in test Sil-1.

Since the phase I screener tests demonstrated that optimum motion generator settings resulted in some residual material on the screen surface, the screener and oversize crusher were restarted and operated for an additional $10 \mathrm{~min}$ after the original shutdown in test SM-4. The results are summarized in Table 4-3. The small quantity of material which discharged during the additional 10-min screening period (i.e., $0.68 \%$ of the total product) demonstrated that a total screening time of $15 \mathrm{~min}$ should be sufficient to reduce the residual material on the screen surface to equilibrium. Therefore, the screener and oversize crusher were operated for a 
TABLE 4-2

TERTIARY CRUSHER PRODUCT SIZE DISTRIBUTIONS: PRIMARY, SECONDARY, AND TERTIARY CRUSHER SHAKEDOWN, PHASE II TESTS

\begin{tabular}{|c|c|c|c|c|c|c|c|c|c|c|}
\hline \multirow[b]{2}{*}{ Test No. } & \multicolumn{10}{|c|}{ Wt $\%$ of Screened Fractions } \\
\hline & $+4750 \mu \mathrm{m}$ & $\begin{array}{l}-4750 \\
+4000 \mu \mathrm{m}\end{array}$ & $\begin{array}{l}-4000 \\
+2800 \mu \mathrm{m}\end{array}$ & $\begin{array}{l}-2800 \\
+2000 \mu \mathrm{m}\end{array}$ & $\begin{array}{l}-2000 \\
+1000 \mu \mathrm{m}\end{array}$ & $\begin{array}{l}-1000 \\
+850 \mu \mathrm{m}\end{array}$ & $\begin{array}{l}-850 \\
+425 \mu \mathrm{m}\end{array}$ & $\begin{array}{l}-425 \\
+355 \mu \mathrm{m}\end{array}$ & $\begin{array}{l}-355 \\
+250 \mu \mathrm{m}\end{array}$ & $-250 \mu \mathrm{m}$ \\
\hline SM-1 & 3.0 & 8.7 & 33.5 & 14.7 & 15.1 & 2.9 & 10.1 & 2.0 & 2.3 & 7.7 \\
\hline SM-2 & 3.2 & 10.4 & 35.9 & 15.0 & 13.6 & 2.9 & 7.6 & 1.6 & 2.1 & 7.7 \\
\hline SM-3 & 3.2 & 8.8 & 36.9 & 15.0 & 13.7 & 3.0 & 7.7 & 1.7 & 2.2 & 7.8 \\
\hline Mean & 3.1 & 9.3 & 35.4 & 14.9 & 14.1 & 2.9 & 8.5 & 1.8 & 2.2 & 7.7 \\
\hline Range & 0.2 & 1.7 & 3.4 & 0.3 & 1.5 & 0.1 & 2.5 & 0.4 & 0.2 & 0.1 \\
\hline $\begin{array}{l}\text { Average } \\
\text { Deviation } \\
\text { From Mean }\end{array}$ & 0.1 & 0.7 & 1.3 & 0.1 & 0.6 & 0 & 1.1 & 0.2 & 0.1 & 0 \\
\hline & \multicolumn{10}{|c|}{ Cumulative Wt $\%$ Less Than } \\
\hline Test No. & $+4750 \mu \mathrm{m}$ & $-4750 \mu \mathrm{m}$ & $-4000 \mu \mathrm{m}$ & $-2800 \mu \mathrm{m}$ & $-2000 \mu \mathrm{m}$ & $-1000 \mu \mathrm{m}$ & $-850 \mu \mathrm{m}$ & $-425 \mu \mathrm{m}$ & $-355 \mu \mathrm{m}$ & $-250 \mu \mathrm{m}$ \\
\hline SM-1 & 100.0 & 97.0 & 88.3 & 54.8 & 40.1 & 25.0 & 22.1 & 12.0 & 10.0 & 7.7 \\
\hline SM-2 & 100.0 & 96.8 & 86.4 & 50.5 & 35.5 & 21.9 & 19.0 & 11.4 & 9.8 & 7.7 \\
\hline$S M-3$ & 100.0 & 96.8 & 88.0 & 51.1 & 36.1 & 22.4 & 19.4 & 11.7 & 10.0 & 7.8 \\
\hline Mean & 100.0 & 96.9 & 87.6 & 52.1 & 37.2 & 23.1 & 20.2 & 11.7 & 9.9 & 7.7 \\
\hline Range & 0 & 0.2 & 1.9 & 4.3 & 4.6 & 3.1 & 3.1 & 0.6 & 0.2 & 0.1 \\
\hline $\begin{array}{l}\text { Average } \\
\text { Deviation } \\
\text { From Mean }\end{array}$ & 0 & 0.1 & 0.8 & 1.8 & 1.9 & 1.3 & 1.3 & 0.2 & 0.1 & 0 \\
\hline
\end{tabular}

Breakdown of Larger Mesh Fractions

\begin{tabular}{c|c|c|c} 
& \multicolumn{3}{|c|}{ Wt \% } \\
\hline Test No. & $-6350 \mu \mathrm{m}$ & $\begin{array}{l}-6350 \\
+4750 \mu \mathrm{m}\end{array}$ & $-4750 \mu \mathrm{m}$ \\
\hline SM-1 & 0.12 & 2.16 & 97.72 \\
SM-2 & 0.14 & 1.98 & 97.88 \\
SM-3 & 0.13 & 2.05 & 97.82 \\
& & & \\
\hline
\end{tabular}


TABLE 4-3

PRODUCT DISTRIBUTION: PHASE II SHAKEDOWN TEST SM-4

\begin{tabular}{lrr}
\multicolumn{3}{c}{ After 7 -min Screening Time } \\
\cline { 2 - 3 } Screener product & $48.625 \mathrm{~kg}$ & $85.76 \%$ \\
Oversize crusher product & $7.691 \mathrm{~kg}$ & $13.56 \%$ \\
Total & $56.316 \mathrm{~kg}$ & $99.32 \%$
\end{tabular}

After Additional 10-min Screening Time

$\begin{array}{lll}\text { Screener product } & 0.168 \mathrm{~kg} & 0.30 \% \\ \text { Oversize discharge } & 0.215 \mathrm{~kg} & 0.38 \% \\ \text { Total } & 0.383 \mathrm{~kg} & 0.68 \% \\ \text { Total recovery } & 56.699 \mathrm{~kg} & 100.0 \%\end{array}$

TABLE $4-4$

SUMMARY OF PHASE II SHAKEDOWN TESTS ${ }^{(a)}$

\begin{tabular}{c|c|c|c}
\hline \multirow{2}{*}{$\begin{array}{l}\text { Test } \\
\text { No. }\end{array}$} & Feed Material & \multicolumn{2}{c}{ Crushing Completion Time } \\
\cline { 2 - 4 } SM-4 & $\begin{array}{l}\text { Half-length H-327 graphite HTGR fue1 } \\
\text { element without fuel holes, } 57.3 \mathrm{~kg}\end{array}$ & $38 \mathrm{~s}$ & $2 \mathrm{~min} 45 \mathrm{~s}$ (b) \\
SM-5 & $\begin{array}{l}\text { Half-length H-327 graphite HTGR fuel } \\
\text { element, } 42.8 \mathrm{~kg}\end{array}$ & 1 min $40 \mathrm{~s}$ & 1 min $45 \mathrm{~s}$ \\
\hline
\end{tabular}

(a) Primary crusher CSS $=5.30 \mathrm{~cm}$, nip angle $=14 \mathrm{deg}$; secondary crusher CSS $=0.64 \mathrm{~cm}$; tertiary crusher gap $=0.27 \mathrm{~cm} ;$ screener $=$ motion generator, 1 bottom weight, 70-deg lead angle; oversize crusher gap $=0.08 \mathrm{~cm}$. 
total of 15 min from commencement of crushing for test SM-5 and a11 subsequent tests. The results also indicated that the majority of the screening was essentially complete shortly after completion of crushing. A summary of the two system shakedown tests is given in Table 4-4.

\subsection{SYSTEM TESTS}

The objectives of the UNIFRAME system are defined in the appendix. The system was designed to meet a majority of these objectives within the constraints of the initial budget and schedule. The activity plan outlined the test program, which was devised to provide sufficient data and observations to demonstrate the degree to which the design objectives had been met. The major objectives of phase II of the test program outlined in the activity plan were

1. To observe and compare the system operation, crushing behavior, throughput rates, and product characteristics of each available type of fuel element.

2. To observe the system material flow and containment concepts.

The following unfueled feed materials were used in the phase II tests:

1. Half-length $\mathrm{H}-327$ graphite fuel elements (tests UE-46 through $\mathrm{UE}-48$ ).

2. Half-length $\mathrm{H}-327$ graphite control rod element (test UE-49).

3. Full-length $\mathrm{H}-327$ graphite fuel elements (tests UE-52, UE-52B, UE-53, and UE-54.

4. Full-length H-451 graphite fuel element (test UE-55). 
To determine the reproducibility of the tests and the range of experimental data, three identical tests were planned for each type of feed material. Unfortunately, only single tests were possible with the control rod and $\mathrm{H}-451$ graphite elements because of the limited supply of these feed materials. However, additional tests of the crushing system were performed in conjunction with the scrap graphite crushing tests discussed in Section 5.

One of the tests (UE-52) was repeated (UE-52B) because the system was shut down during the operation by accidental tripping of the main switch. Crushing had begun when the accidental shutdown occurred. All components except the primary crusher restarted easily under the partially loaded condition. Owing to belt slippage, it was necessary to remove all material from the primary crushing cavity and recharge it after the crusher was in operation. Because of the potential effects of this abnormal operation on product size distribution, screening efficiency, and throughput, the test was repeated to obtain data produced under conditions more similar to those of the other tests. The components of the ventilation enclosure in these areas remained off as they had during shakedown testing so that the primary and secondary crushing completion times could be determined. A plexiglass viewport was installed in the ventilation shroud between the tertiary crusher and the screener so that tertiary crushing completion times and screener operation could be observed.

The screener and oversize crusher were operated for $15 \mathrm{~min}$ after crushing had commenced to reduce the quantity of holdup on the screener table to an equilibrium value at the end of each test. All other components were shut down shortly after crushing had been completed. Crushed products which discharged from the screener and oversize crusher were separately collected during each test for subsequent size distribution determinations. The system was cleaned out after completion of all tests to determine dust and material holdup. 
4.3.1. Equipment Operation and Test Observations

Other than the inadvertent system shutdown during test UE-52, there were no problems with the operation of any UNIFRAME equipment in any test. Perturbations in the crushing rates occurred in three tests, but none resulted in cessation of crushing or permanent material holdup in any of the crushing cavities. Several graphite fragments formed a temporary bridge in the secondary crusher during test UE-53. This bridge was similar to the one observed earlier in shakedown test SM-4. In test UE-53 a single long fragment in the primary crusher was temporarily prevented from discharging into the secondary crushing cavity by the level of material in the secondary crusher. This level normally occurred in all tests because of the difference in the crushing rates of the primary and the secondary crusher. When the level in the secondary crusher was reduced by crushing, the fragment discharged normally. In test UE-55 a single fragment in the primary crusher temporarily rode up and down with the action of the pitman (similar to the occurrences observed in shakedown tests SM-1 and SM-5), and a temporary bridge occurred in the secondary crusher.

\subsubsection{Material Balances}

To establish individual material balances for each test, the feed materials were weighed prior to charging, and the crushed products collected separately from the screener and oversize crusher were weighed at the end of each test. At the conclusion of phase II testing the system was inspected, and material and dust which were held up on the various components were removed and weighed to establish the total material unaccounted for (MUF). Since the system was not cleaned out after the two system shakedown tests (SM-4 and SM-5), the material holdup represented accumulations during a throughput which included these two tests. The material balances and material accountability including identification of material holdup areas are given in Table 4-5. 
TABLE $\quad 4-5$

MATERIAL BALANCE: PHASE II TESTS

\begin{tabular}{l|c|c|c|c}
\hline \multicolumn{5}{|c|}{ Continuous Run Balance } \\
\hline Test No. & $\begin{array}{c}\text { Charge } \\
(\mathrm{kg})\end{array}$ & $\begin{array}{c}\text { Recovery } \\
(\mathrm{kg})\end{array}$ & $\begin{array}{c}\text { Gain (t) } \\
\text { or Loss }(-)\end{array}$ & $\begin{array}{c}\text { MUF } \\
\text { (\% of } \\
\text { Charge) }\end{array}$ \\
\hline SM-4 & 57.300 & 56.699 & $(-) 0.601$ & 1.05 \\
SM-5 & 42.800 & 42.833 & $(+) 0.083$ & 0.19 \\
UE-46 & 43.500 & 43.523 & $(+) 0.023$ & 0.05 \\
UE-47 & 45.000 & 45.585 & $(+) 0.585$ & 1.30 \\
UE-48 & 45.100 & 46.628 & $(+) 1.528$ & 3.39 \\
UE-49 & 43.800 & 43.314 & $(-) 0.486$ & 1.11 \\
UE-52 & 86.450 & 86.250 & $(-) 0.200$ & 0.23 \\
UE-52B & 90.200 & 87.662 & $(-) 2.538$ & 2.81 \\
UE-53 & 86.750 & 86.434 & $(-) 0.316$ & 0.36 \\
UE-54 & 89.250 & 89.102 & $(-) 0.148$ & 0.17 \\
UE-55 & 90.500 & 89.408 & $(-) 1.092$ & 1.21 \\
Tota1 (a) & 720.650 & 717.438 & $(-) 3.212$ & 0.45 \\
\hline
\end{tabular}

Clean-Out at Conclusion of Testing

\begin{tabular}{l|c|c}
\hline \multicolumn{1}{c|}{ Description } & $\begin{array}{c}\text { Quantity } \\
(\mathrm{kg})\end{array}$ & $\begin{array}{c}\% \text { of } \\
\text { Charge }\end{array}$ \\
\hline Holdup on screener table & 0.729 & 0.10 \\
Dust in screener housing & 0.640 & 0.09 \\
Dust in oversize crusher housing & $\underline{0.472}$ & $\underline{0.07}$ \\
Total & $\underline{1.841}$ & 0.26 \\
\hline
\end{tabular}

Grand Totals

\begin{tabular}{c|c|c|c|c}
\hline Test No. & $\begin{array}{c}\text { Charge } \\
(\mathrm{kg})\end{array}$ & $\begin{array}{c}\text { Recovery } \\
(\mathrm{kg})\end{array}$ & $\begin{array}{c}\text { Gain (+) } \\
\text { or Loss (-) }\end{array}$ & $\begin{array}{c}\text { MUF } \\
(\% \text { of } \\
\text { Charge) }\end{array}$ \\
\hline SM-4 through UE-55 & 720.650 & 719.279 & $(-) 1.371$ & 0.19 \\
\hline
\end{tabular}

(a) 103 screener blinded holes $(0.9 \%)$. 
The MUF in individual tests ranged from a low of $0.05 \mathrm{wt} \%$ to a high of 3.39 wt \% of the charges. A summation of the total throughput and material recovered for all tests yielded an MUF of 0.45 wt \% of the total throughput. Recovery during system clean-out was 0.26 wt \% of the throughput, resulting in a final MUF of 0.19 wt \% of the throughput.

There was no measurable material holdup in the primary, secondary, or tertiary crushing areas. However, as expected at the motion generator settings used, holdup occurred on the screener table $(729 \mathrm{~g}$, or $0.10 \%$ of throughput), as was previously observed. Within the screener housing, $640 \mathrm{~g}$ of dust $(0.09 \%$ of throughput) were recovered from the spring supports, the slide gate valve internal mechanisms, and the sloping surface of the ventilation shroud between the tertiary crusher and the screener. An additional $472 \mathrm{~g}(0.07 \%$ of the throughput) were recovered from the areas behind the two wear plates of the oversize crusher. This was expected because of observations made during phase I individual tests of theoversize crusher. No other areas of material holdup were discovered. Screen blinding of $0.9 \%$ at the end of the tests was less than expected based on previous screener tests, which indicated that the self-cleaning device was successful in reducing blinding buildup with significantly large quantities of throughput.

\subsubsection{Crushing Rates}

Primary and secondary crushing times for the various types of fuel elements used in the phase II tests are given in Table 4-6. Pertubations in the crushing rates as described in Section 4.3 .2 were disregarded in this table so that typical rates could be obtained for comparison with the rates for other types of elements. In no instance did these temporary crushing rate reductions result in total system throughput time exceeding 15 min, including the test (UE-55) in which both primary and secondary crushing rate reductions occurred. 
TABLE $4-6$

CRUSHING TIMES: PHASE II TESTS

\begin{tabular}{l|c|c}
\hline \multirow{2}{*}{ Test No. } & \multicolumn{2}{|c}{ Crushing Time (s) } \\
\cline { 2 - 3 } & Primary & Secondary \\
\hline
\end{tabular}

Half-Length H-327 Fuel Elements

\begin{tabular}{l|c|c}
\hline UE-46 & 35 & 92 \\
UE-47 & 55 & 95 \\
UE-48 & 40 & 90 \\
Mean & 43 & 92 \\
Range & 20 & 5 \\
\hline Ha1f-Length H-327 Control Rod Element \\
\hline UE-49 & 29 & 177 \\
\hline Fu11-Length H-327 FueI Elements \\
\hline UE-52B & 34 & 180 (a) \\
UE-53 & $30{ }^{\text {(b) }}$ & 205 \\
UE-54 & 33 & 180 \\
Mean & 32 & 188 \\
Range & 4 & 25 \\
\hline
\end{tabular}

(a) A11 except a minor quantity which formed a temporary bridge which crushed in $420 \mathrm{~s}$.

(b) All except one long fragment which could not discharge into the secondary crusher owing to material level.

(c) All except one piece which crushed in $210 \mathrm{~s}$.

(d) Temporary bridge [as in footnote (a)] which crushed in $440 \mathrm{~s}$. 
No significant lag between completion of secondary and tertiary crushing could be detected, and observations of the screener indicated that screening was also essentially complete at that time, except, of course, for the reduction of the normal holdup to equilibrium. Therefore, the secondary crushing completion times can be regarded as approximations of the total system processing times.

The significant differences noted in the crushing times (Table 4-6) are

1. Secondary crushing times (i.e., approximate process times) were less for the half-length fuel elements than for the half-length control rod element, possibly indicating the effect of the previously observed larger control rod primary crusher product on the secondary crushing rate, and therefore the total process time.

2. As expected, the process times for full-length fuel elements were approximately twice those for half-length fuel elements.

3. The primary crushing and process time for $\mathrm{H}-451$ graphite was greater than that for H-357 graphite elements of comparable size, indicating a difference in the crushing behavior of these types of graphite.

\subsubsection{Relative Quantities of Screener and Oversize Crusher Product}

The quantities of material discharged from the screener and the oversize crusher relative to the total product were studied to ascertain the screening efficiencies. The product distribution for the various types of fuel elements used in the phase II tests are given in Table 4-7. Significant differences noted from Table $4-7$ are 
TABLE 4-7

PRODUCT DISTRIBUTIONS: PHASE II TESTS

\begin{tabular}{l|c|c|c|c}
\hline \multirow{2}{*}{ Test No. } & \multicolumn{3}{|c|}{$\begin{array}{c}\text { Oversize } \\
\text { Crusher Product }\end{array}$} & \multicolumn{2}{c}{ Screener Product } \\
\cline { 2 - 5 } & $\mathrm{kg}$ & $\begin{array}{c}\text { \% of Total } \\
\text { Product }\end{array}$ & $\mathrm{kg}$ & $\begin{array}{c}\% \text { of Total } \\
\text { Product }\end{array}$ \\
\hline
\end{tabular}

Half-Length Standard H-327 Unfueled Graphite Fuel Elements

\begin{tabular}{l|r|r|r|r}
\hline UE-46 & 7.572 & 17.40 & 35.951 & 82.60 \\
UE-47 & 7.697 & 16.88 & 37.888 & 83.12 \\
UE-48 & 4.826 & 10.35 & 41.802 & 89.65 \\
Mean & 6.698 & 14.88 & 38.547 & 85.12 \\
Range & 2.871 & 7.05 & 5.851 & 7.05 \\
\hline
\end{tabular}

Half-Length H-327 Unfueled Graphite Control Rod Element

\begin{tabular}{l|l|l|l|l}
\hline $\mathrm{UE}-49$ & 3.819 & 8.82 & 39.495 & 91.18 \\
\hline
\end{tabular}

Ful1-Length H-327 Unfueled Graphite Fuel Elements

\begin{tabular}{l|r|r|r|r}
\hline UE-52B & 14.546 & 16.59 & 73.116 & 83.41 \\
UE-53 & 14.839 & 17.17 & 71.595 & 82.83 \\
UE-54 & 15.302 & 17.17 & 73.800 & 82.83 \\
Mean & 14.896 & 16.98 & 72.837 & 83.02 \\
Range & 0.756 & 0.58 & 2.205 & 0.58 \\
\hline
\end{tabular}

Full-Length H-451 Unfueled Graphite Fuel Elements

\begin{tabular}{l|c|c|c|c}
\hline UE-55 & 12.008 & 13.43 & 77.400 & 86.57 \\
\hline \multicolumn{5}{c|}{ Summary of A11 Tests } \\
\hline Mean & -- & 14.73 & -- & 85.27 \\
Range & -- & 8.53 & -- & 8.58 \\
\hline
\end{tabular}


1. The quantity of oversize crusher product relative to the total product was slightly lower from crushing of the half-length control rod element $(8.82 \%)$ than it was from crushing of any of the half-length fuel elements (10.35\% minimum). Similar results were obtained with these types of elements in the phase I screener tests, but they were more pronounced (i.e., $3.7 \%$ and $13.4 \%$ ). Since the process times were longer for control rod elements in both phases of testing, the difference is attributed to the lower throughput rates, which improved screener efficiency.

2. The quantity of oversize crusher product was lower for H-451 graphite (13.43\%) than for any $\mathrm{H}-357$ graphite element of comparable size ( $16.59 \%$ minimum). This difference is attributable to the effect of processing time on screener efficiency (see Section 4.3.4).

3. The ranges of the results for half- and full-length fuel elements overlapped sufficiently, indicating little difference in their screening efficiencies. The longer process times for the fullsize elements resulted in similar throughput rates and screening efficiencies (see Section 4.3.4).

\subsubsection{Product Characteristics}

Screen analyses were separately performed on products discharged from the screener and oversize crusher for each of the phase II tests. Samples of a size suitable for analysis were obtained by reducing each product in a 12 to 1 sample splitter. The weight percent of the material in each of the screener fractions and the cumulative weight percent less than each mesh size were determined from the screening results. To obtain an estimate of the combined screener and oversize crusher product size distributions, (i.e., total system product), composites were calculated using the screen analysis and relative proportions of the two product to the total product, 
as shown in Table 4-7. The size distributions of the composites were recalculated assuming that the material contained 17 wt \% 850- $\mu \mathrm{m}$ fuel particles to provide a comparison of the UNIFRAME products with the estimated primary burner feed size distribution requirements. The means, ranges, and average deviations from the mean were calculated for fuel elements (i.e., half- and full-length $\mathrm{H}-351$ graphite) on which replicate tests were made, and the means and ranges were calculated for the phase II tests. Replicate analyses were performed on the products from test UE-48 to obtain an estimate of the deviations caused by errors in the screen analysis. These analyses and earlier analyses of tertiary crusher products from the shakedown tests (SM-1, SM-2, and SM-3) provided the following information:

1. Comparison of the screener product size distributions produced by crushing various types of fuel elements.

2. Comparison of the oversize crusher product size distributions produced by crushing various types of fuel elements.

3. Comparison of the composite product size distributions produced by crushing various types of fuel elements and determination of the effect of oversize crushing on reduction of the differences between the products.

4. Comparison of the expected UNIFRAME products with estimated primary burner feed size distribution requirements.

5. Estimation of the ranges and averages of the results expected from crushing various types of fuel elements.

6. Estimation of the experimental exrors induced by variabilities in the screen analysis.

7. Estimation of the changes in the tertiary crusher product effected by screening and oversize crushing. 
4.3.5.1. Screener Product Size Distributions. Screener product size distributions obtained from crushing various types of fuel elements are shown in Table 4-8. These results are also compared in Fig. 4-1. An estimate of the erxor introduced by screen analysis was obtained from the replicate analysis shown in Table 4-9. The following significant differences were discerned:

1. The screener product from crushing half-length control rod elements differed significantly from that of half-length fuel elements in only the $-4750+4000 \mu \mathrm{m}$ mesh fraction. In this fraction, the quantity was greater in the control rod product (12.5\%) than in any of the fuel element products (10.4\% maximum).

2. The screener product obtained from crushing a full-length $\mathrm{H}-451$ graphite fuel element differed significantly from that of fulllength $\mathrm{H}-357$ graphite fuel elements as follows:

a. The quantity of +4750 and $-4750+4000 \mu \mathrm{m}$ mesh material was greater in the $\mathrm{H}-451$ graphite product than in any of the $\mathrm{H}-357$ graphite products $(3.6 \%$ versus $0.9 \%$ maximum and $13.1 \%$ versus $8.6 \%$ maximum, respectively).

b. The quantity of $-2800+2000 \mu \mathrm{m}$ mesh material was less in the $\mathrm{H}-451$ graphite product $(13.6 \%)$ than in any of the $\mathrm{H}-357$ graphite products ( $15.7 \%$ minimum).

c. The ranges of values for all mesh fractions overlapped sufficiently for the half- and full-size H-357 graphite fuel element screener products, indicating no difference in these products.

The cumulative weight percents of materials which were less than each stated size are given in Table 4-10 for the screener products, and these 
TABLE 4-8

SCREENER PRODUCT SIZE DISTRIBUTIONS: PHASE II TESTS

\begin{tabular}{|c|c|c|c|c|c|c|c|c|c|c|}
\hline \multirow[b]{2}{*}{ Test No. } & \multicolumn{10}{|c|}{ Wt \% of Screened Fractions } \\
\hline & $+4750 \mu \mathrm{m}$ & $\begin{array}{l}-4750 \\
+4000 \mu \mathrm{m}\end{array}$ & $\begin{array}{l}-4000 \\
+2800 \mu \mathrm{m}\end{array}$ & $\begin{array}{l}-2800 \\
+2000 \mu \mathrm{m}\end{array}$ & $\begin{array}{l}-2000 \\
+1000 \mu \mathrm{m}\end{array}$ & $\begin{array}{l}-1000 \\
+850 \mu \mathrm{m}\end{array}$ & $\begin{array}{l}-850 \\
+425 \mu \mathrm{m}\end{array}$ & $\begin{array}{l}-425 \\
+355 \mu \mathrm{m}\end{array}$ & $\begin{array}{l}-355 \\
+250 \mu \mathrm{m}\end{array}$ & $-250 \mu \mathrm{m}$ \\
\hline \multicolumn{11}{|c|}{ Half-Length Standard H-327 Unfueled Graphite Fuel Elements } \\
\hline $\mathrm{UE}-46$ & 0.2 & 10.0 & 39.9 & 14.0 & 14.0 & 2.0 & 8.0 & 2.0 & 2.0 & 8.0 \\
\hline $\mathrm{UE}-47$ & 0.8 & 10.4 & 41.5 & 14.3 & 13.7 & 2.1 & 7.3 & 1.5 & 1.9 & 6.5 \\
\hline $\mathrm{UE}-48$ & 0.5 & 9.0 & 44.0 & 16.7 & 14.1 & 1.9 & 6.4 & 1.2 & 1.5 & 4.7 \\
\hline Mean & 0.5 & 9.8 & 41.8 & 15.0 & 13.9 & 2.0 & 7.2 & 1.6 & 1.8 & 6.4 \\
\hline Range & 0.6 & 1.4 & 4.1 & 2.7 & 0.4 & 0.2 & 1.6 & 0.8 & 0.5 & 3.3 \\
\hline $\begin{array}{l}\text { Average } \\
\text { Deviation } \\
\text { From Mean }\end{array}$ & 0.2 & 0.5 & 1.5 & 1.1 & 0.2 & 0.1 & 0.6 & 0.3 & 0.2 & 1.1 \\
\hline \multicolumn{11}{|c|}{ Half-Length $\mathrm{H}-327$ Unfueled Graphite Control Rod Element } \\
\hline $\mathrm{UE}-49$ & 0.8 & 12.5 & 41.6 & 16.0 & 13.5 & 2.0 & 5.9 & 1.1 & 1.6 & 5.0 \\
\hline \multicolumn{11}{|c|}{ Ful1-Length Standard H-327 Unfueled Graphite Fuel Elements } \\
\hline $\mathrm{UE}-52 \mathrm{~B}$ & 0.4 & 8.5 & 42.1 & 15.7 & 13.7 & 2.1 & 7.1 & 1.4 & 2.0 & 7.0 \\
\hline UE-53 & 0.9 & 8.6 & 30.9 & 16.8 & 16.5 & 2.5 & 7.2 & 1.3 & 1.5 & 5.8 \\
\hline UE-54 & 0.4 & 6.9 & 43.2 & 17.4 & 14.6 & 1.9 & 6.8 & 1.3 & 1.6 & 5.9 \\
\hline Mean & 0.6 & 8.0 & 41.4 & 16.6 & 14.9 & 2.2 & 7.0 & 1.3 & 1.7 & 6.2 \\
\hline Range & 0.5 & 1.7 & 4.3 & 1.7 & 2.8 & 0.6 & 0.4 & 0.1 & 0.5 & 1.2 \\
\hline $\begin{array}{l}\text { Average } \\
\text { Deviation } \\
\text { From Mean }\end{array}$ & 0.2 & 0.7 & 1.7 & 0.6 & 1.0 & 0.3 & 0.2 & 0 & 0.2 & 0.5 \\
\hline \multicolumn{11}{|c|}{ Ful1-Length Standard $\mathrm{H}-451$ Unfueled Graphite Fuel Element } \\
\hline $\mathrm{UE}-55$ & 3.6 & 13.1 & 38.3 & 13.6 & 14.5 & 2.0 & 6.8 & 1.2 & 1.6 & 5.3 \\
\hline \multicolumn{11}{|c|}{ Summary of All Tests } \\
\hline Mean & 1.0 & 9.9 & 41.2 & 15.6 & 14.3 & 2.1 & 6.9 & 1.4 & 1.7 & 6.0 \\
\hline Range & 3.4 & 6.2 & 5.7 & 3.8 & 3.0 & 0.6 & 2.1 & 0.9 & 0.5 & 3.3 \\
\hline
\end{tabular}




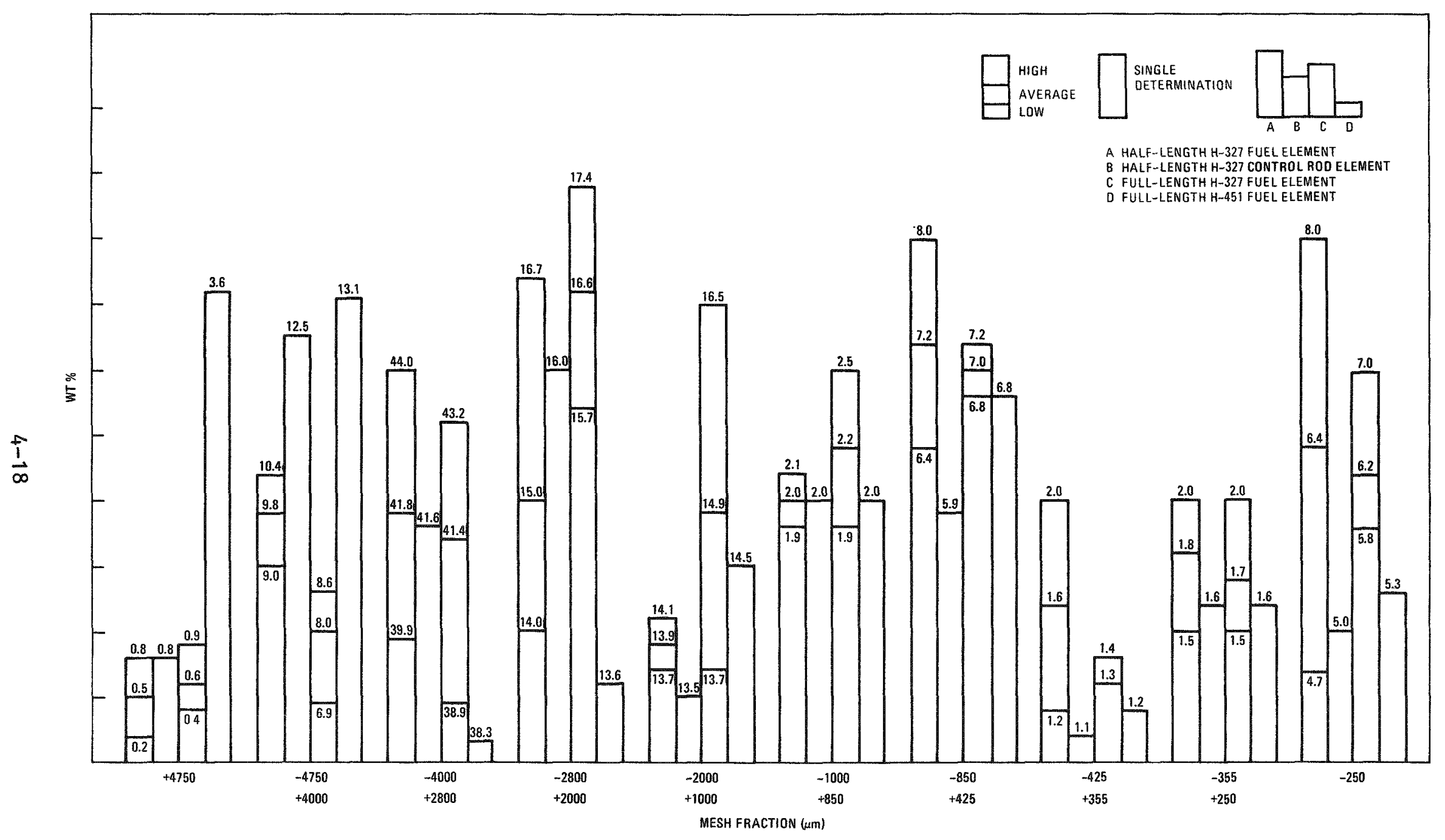

Fig. 4-1. Screener product comparison by mesh size: phase II tests 
TABLE 4-9

REPLICATE SCREEN ANALYSIS OF SCREENER PRODUCT FROM PHASE II TEST UE-48

\begin{tabular}{|c|c|c|c|c|c|c|c|c|c|c|}
\hline \multirow[b]{2}{*}{ Sample No. } & \multicolumn{10}{|c|}{ Wt $\%$ of Screened Fractions } \\
\hline & $+4750 \mu \mathrm{m}$ & $\begin{array}{l}-4750 \\
+4000 \mu \mathrm{m}\end{array}$ & $\begin{array}{l}-4000 \\
+2800 \mu \mathrm{m}\end{array}$ & $\begin{array}{l}-2800 \\
+2000 \mu \mathrm{m}\end{array}$ & $\begin{array}{l}-2000 \\
+1000 \mu \mathrm{m}\end{array}$ & $\begin{array}{l}-1000 \\
+850 \mu \mathrm{m}\end{array}$ & $\begin{array}{l}-850 \\
+425 \mu \mathrm{m}\end{array}$ & $\begin{array}{l}-425 \\
+355 \mu \mathrm{m}\end{array}$ & $\begin{array}{l}-355 \\
+250 \mu \mathrm{m}\end{array}$ & $-250 \mu \mathrm{m}$ \\
\hline \multicolumn{11}{|c|}{ Half-Length Standard H-327 Unfueled Gr } \\
\hline 1 & 0.5 & 9.1 & 43.6 & 16.8 & 14.0 & 2.1 & 6.4 & 1.2 & 1.6 & 4.7 \\
\hline 2 & 0.5 & 8.8 & 44.7 & 16.4 & 13.9 & 1.9 & 6.3 & 1.2 & 1.5 & 4.8 \\
\hline 3 & 0.5 & 9.2 & 43.8 & 16.9 & 14.3 & 1.8 & 6.4 & 1.1 & 1.5 & 4.5 \\
\hline Mean & 0.5 & 9.0 & 44.0 & 16.7 & 14.1 & 1.9 & 6.4 & 1.2 & 1.5 & 4.7 \\
\hline Range & 0 & 0.4 & 1.1 & 0.5 & 0.4 & 0.3 & 0.1 & 0.1 & 0.1 & 0.3 \\
\hline $\begin{array}{l}\text { Average } \\
\text { Deviation } \\
\text { From Mean }\end{array}$ & 0 & 0.2 & 0.4 & 0.2 & 0.2 & 0.1 & 0 & 0 & 0 & 0.1 \\
\hline & \multicolumn{10}{|c|}{ Cumulative Wt \% Less Than } \\
\hline Sample No. & $+4750 \mu \mathrm{m}$ & $-4750 \mu \mathrm{m}$ & $-4000 \mu \mathrm{m}$ & $-2800 \mu \mathrm{m}$ & $-2000 \mu \mathrm{m}$ & $-1000 \mu \mathrm{m}$ & $-850 \mu \mathrm{m}$ & $-425 \mu \mathrm{m}$ & $-355 \mu \mathrm{m}$ & $-250 \mu \mathrm{m}$ \\
\hline \multicolumn{11}{|c|}{ Half-Length Standard H-327 Unfueled Graphite Fuel Element } \\
\hline 1 & 100.0 & 99.5 & 90.4 & 46.8 & 30.0 & 16.0 & 13.9 & 7.5 & 6.3 & 4.7 \\
\hline 2 & 100.0 & 99.5 & 90.7 & 46.0 & 29.6 & 15.7 & 13.8 & 7.5 & 6.3 & 4.8 \\
\hline 3 & 100.0 & 99.5 & 90.3 & 46.5 & 29.6 & 15.3 & 13.5 & 7.1 & 6.0 & 4.5 \\
\hline Mean & 100.0 & 99.5 & 90.5 & 46.4 & 29.7 & 15.7 & 13.7 & 7.4 & 6.2 & 4.7 \\
\hline Range & 0 & 0 & 0.4 & 0.8 & 0.4 & 0.7 & 0.4 & 0.4 & 0.3 & 0.3 \\
\hline $\begin{array}{l}\text { Average } \\
\text { Deviation } \\
\text { From Mean }\end{array}$ & 0 & 0 & 0.2 & 0.3 & 0.2 & 0.2 & 0.2 & 0.2 & 0.1 & 0.1 \\
\hline
\end{tabular}


TABLE $\quad 4-10$

SCREENER PRODUCT SIZE DISTRTBUTIONS (CUMULATIVE WT \%): PHASE II TESTS

\begin{tabular}{|c|c|c|c|c|c|c|c|c|c|c|}
\hline \multirow[b]{2}{*}{ Test No. } & \multicolumn{10}{|c|}{ Cumulative Wt \% Less Than } \\
\hline & $+4750 \mu \mathrm{m}$ & $-4750 \mu \mathrm{m}$ & $-4000 \mu \mathrm{m}$ & $-2800 \mu \mathrm{m}$ & $-2000 \mu \mathrm{m}$ & $-1000 \mu \mathrm{m}$ & $-850 \mu \mathrm{m}$ & $-425 \mu \mathfrak{m}$ & $-355 \mu \mathrm{m}$ & $-250 \mu \mathrm{m}$ \\
\hline \multicolumn{11}{|c|}{ Half-Length Standard H-327 Unfueled Graphite Fuel Elements } \\
\hline $\mathrm{UE}-46$ & 100.0 & 99.9 & 89.9 & 50.0 & 36.0 & 22.0 & 20.0 & 12.0 & 10.0 & 8.0 \\
\hline $\mathrm{UE}-47$ & 100.0 & 99.2 & 88.0 & 47.3 & 33.0 & 19.3 & 17.2 & 9.9 & 8.4 & 6.5 \\
\hline UE- 48 & 100.0 & 99.5 & 90.5 & 46.4 & 29.7 & 15.7 & 13.7 & 7.4 & 6.2 & 4.7 \\
\hline Mean & 100.0 & 99.5 & 89.5 & 47.9 & 32.9 & 19.0 & 17.0 & 9.8 & 8.2 & 6.4 \\
\hline Range & 0 & 0.7 & 2.5 & 3.6 & 6.3 & 6.3 & 6.3 & 4.6 & 3.8 & 3.3 \\
\hline $\begin{array}{l}\text { Average } \\
\text { Deviation } \\
\text { From Mean }\end{array}$ & 0 & 0.2 & 1.0 & 1.4 & 2.1 & 2.2 & 2.2 & 1.6 & 1.3 & 1.1 \\
\hline \multicolumn{11}{|c|}{ Half-Length $\mathrm{H}-327$ Unfueled Graphite Control Rod Element } \\
\hline $\mathrm{UE}-49$ & 100.0 & 99.2 & 86.7 & 45.1 & 29.1 & 15.6 & 13.6 & 7.7 & 6.6 & 5.0 \\
\hline \multicolumn{11}{|c|}{ Ful1-Length Standard H-327 Unfueled Graphite Fuel Elements } \\
\hline UE-52B & 100.0 & 99.6 & 91.1 & 49.0 & 33.3 & 19.6 & 17.5 & 10.4 & 9.0 & 7.0 \\
\hline $\mathrm{UE}-53$ & 100.0 & 99.1 & 90.5 & 51.6 & 34.8 & 18.3 & 15.8 & 8.6 & 7.3 & 5.8 \\
\hline UE-54 & 100.0 & 99.6 & 92.7 & 49.5 & 32.1 & 17.5 & 15.6 & 8.8 & 7.5 & 5.9 \\
\hline Mean & 100.0 & 99.4 & 91.4 & 50.0 & 33.4 & 18.5 & 16.3 & 9.3 & 7.9 & 6.2 \\
\hline Range & 0 & 0.5 & 2.2 & 2.6 & 2.7 & 2.1 & 1.9 & 1.8 & 1.7 & 1.2 \\
\hline $\begin{array}{l}\text { Average } \\
\text { Deviation } \\
\text { From Mean }\end{array}$ & 0 & 0.2 & 0.8 & 1.0 & 0.9 & 0.8 & 0.8 & 0.8 & 0.7 & 0.6 \\
\hline \multicolumn{11}{|c|}{ Full-Length Standard H-451 Unfueled Graphite Fue1 Element } \\
\hline UE-55 & 100.0 & 96.4 & 83.3 & 45.0 & 31.4 & 16.9 & 14.9 & 8.1 & 6.9 & 5.3 \\
\hline \multicolumn{11}{|c|}{ Summary of A11 Tests } \\
\hline Mean & 100.0 & 99.1 & 89.1 & 48.0 & 32.4 & 18.1 & 16.0 & 9.1 & 7.7 & 6.0 \\
\hline Range & 0 & 3.5 & 9.4 & 6.6 & 6.9 & 6.4 & 6.4 & 4.6 & 3.8 & 3.3 \\
\hline
\end{tabular}


results are compared in Fig. 4-2. An estimate of the error introduced by the screen analysis was obtained from the replicate analyses shown in Table 4-9. The significant differences determined are

1. The total quantity of material smaller than 4000- $\mu \mathrm{m}$ mesh size was significantly less in the screener product obtained from crushing half-length control rod elements $(86.7 \%)$ than in any of the halflength fuel element products ( $88.0 \%$ minimum). No other significant differences were noted.

2. The total quantity of material smaller than each mesh size from $4750 \mu \mathrm{m}$ and below was generally less in the screener product obtained from crushing full length $\mathrm{H}-451$ graphite fuel elements than in any of the full-length $\mathrm{H}-357$ graphite fuel element products. However, considering the errors introduced by screen analysis (Table 4-9), there were only three differences which were significant: the $-4750,-4000$, and $-2800 \mu \mathrm{m}$ values $(96.4 \%$ versus $99.1 \%$ minimum, $83.3 \%$ versus $90.5 \%$ minimum, and $45.0 \%$ versus $49.0 \%$ minimum, respectively).

3. The ranges of values for all cumulative weight percents overlapped sufficiently for half- and full-size H-327 graphite fuel element screener products, indicating no significant differences in these products.

\subsubsection{Oversize Crusher Product Size Distributions. Oversize crusher} product size distributions obtained from crushing various types of fuel elements are shown in Table 4-11. These results are compared in Fig. 4-3. An estimate of the error introduced by the screen analysis was obtained from the replicate analyses shown in Table 4-12. The cumulative weight percents of materials which were less than each stated size for the oversize crusher product are given in Table 4-13; these results are compared in Fig. 4-4. The significant differences shown by these data are as follows: 


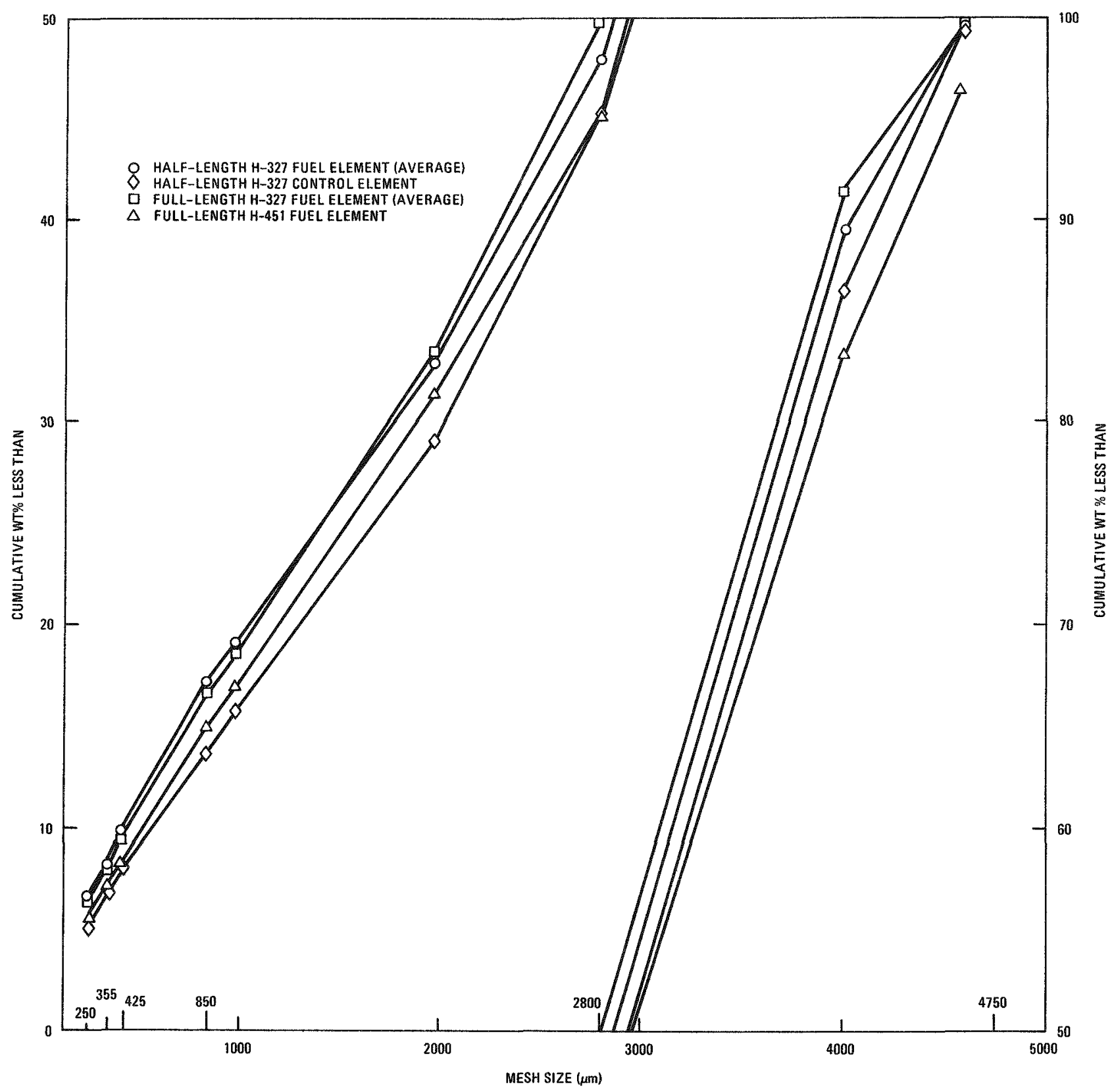

Fig. 4-2. Screener product comparison by cumulative weight percent: phase II tests 
TABLE $4-11$

OVERSIZE CRUSHER PRODUCT SIZE DISTRIBUTIONS: PHASE II TESTS

\begin{tabular}{|c|c|c|c|c|c|c|c|c|c|c|}
\hline \multirow[b]{2}{*}{ Test No. } & \multicolumn{10}{|c|}{ Wt $\%$ of Screened Fractions } \\
\hline & $+4750 \mu \mathrm{m}$ & $\begin{array}{l}-4750 \\
+4000 \mu \mathrm{m}\end{array}$ & $\begin{array}{l}-4000 \\
+2800 \mu \mathrm{m}\end{array}$ & $\begin{array}{l}-2800 \\
+2000\end{array}$ & $\begin{array}{l}-2000 \\
+1000 \mu \mathrm{m}\end{array}$ & $\begin{array}{l}-1000 \\
+850 \mu \mathrm{m}\end{array}$ & $\begin{array}{l}-850 \\
+425 \mu \mathrm{m}\end{array}$ & $\begin{array}{l}-425 \\
+355 \mu \mathrm{m}\end{array}$ & $\begin{array}{l}-355 \\
+250 \mu \mathrm{m}\end{array}$ & $-250 \mu \mathrm{m}$ \\
\hline
\end{tabular}

Half-Length Standard H-327 Unfueled Graphite Fuel Elements

\begin{tabular}{l|r|r|r|r|r|r|r|r|r|r}
\hline UE-46 & 5.6 & 15.1 & 21.9 & 17.3 & 24.5 & 2.6 & 6.6 & 0.8 & 1.0 & 4.6 \\
UE-47 & 12.3 & 19.9 & 23.0 & 11.6 & 15.5 & 2.1 & 5.9 & 1.0 & 1.3 & 7.4 \\
UE-48 & 18.0 & 26.3 & 21.3 & 9.5 & 11.4 & 1.7 & 4.5 & 0.7 & 1.0 & 5.7 \\
Mean & 12.0 & 20.4 & 22.1 & 12.8 & 17.1 & 2.1 & 5.7 & 0.8 & 1.1 & 5.9 \\
Range & 12.4 & 11.2 & 1.7 & 7.8 & 13.1 & 0.9 & 2.1 & 0.3 & 0.3 & 2.8 \\
Average & 4.2 & 3.9 & 0.6 & 3.0 & 4.9 & 0.3 & 0.8 & 0.1 & 0.1 & 1.0 \\
Deviation & & & & & & & & & & \\
From Mean & & & & & & & &
\end{tabular}

Half-Length H-327 Unfueled Graphite Control Rod Element

\begin{tabular}{|c|c|c|c|c|c|c|c|c|c|c|}
\hline $\mathrm{UE}-49$ & 16.9 & 18.4 & 16.5 & 10.9 & 15.2 & 2.7 & 7.3 & 1.2 & 1.7 & 9.2 \\
\hline \multicolumn{11}{|c|}{ Full-Length Standard H-327 Unfueled Graphite Fuel Elements } \\
\hline $\mathrm{UE}-52 \mathrm{~B}$ & 9.6 & 15.4 & 24.3 & 16.4 & 17.9 & 2.1 & 5.9 & 1.0 & 1.3 & 6.1 \\
\hline UE-53 & 5.7 & 12.0 & 21.4 & 17.3 & 21.6 & 2.6 & 7.9 & 1.4 & 1.9 & 8.2 \\
\hline UE-54 & 6.7 & 17.5 & 25.2 & 17.7 & 19.6 & 2.1 & 5.1 & 0.8 & 1.1 & 4.2 \\
\hline Mean & 7.3 & 15.0 & 23.6 & 17.1 & 19.7 & 2.3 & 6.3 & 1.1 & 1.4 & 6.2 \\
\hline Range & 3.9 & 5.5 & 3.8 & 1.3 & 3.7 & 0.5 & 2.8 & 0.6 & 0.8 & 4.0 \\
\hline $\begin{array}{l}\text { Average } \\
\text { Deviation } \\
\text { From Mean }\end{array}$ & 1.5 & 2.0 & 1.5 & 0.5 & 1.3 & 0.2 & 1.1 & 0.2 & 0.3 & 1.4 \\
\hline \multicolumn{11}{|c|}{ Full-Length Standard H-451 Unfueled Graphite Fuel Element } \\
\hline UE-55 & 9.3 & 16.3 & 21.2 & 14.6 & 23.0 & 2.4 & 6.2 & 0.9 & 1.1 & 5.0 \\
\hline \multicolumn{11}{|c|}{ Summary of AIl Tests } \\
\hline Mean & 10.5 & 17.6 & 21.8 & 14.4 & 18.6 & 2.3 & 6.2 & 1.0 & 1.3 & 6.3 \\
\hline Range & 12.4 & 14.3 & 8.7 & 8.2 & 13.1 & 1.0 & 3.4 & 0.7 & 0.9 & 4.6 \\
\hline
\end{tabular}




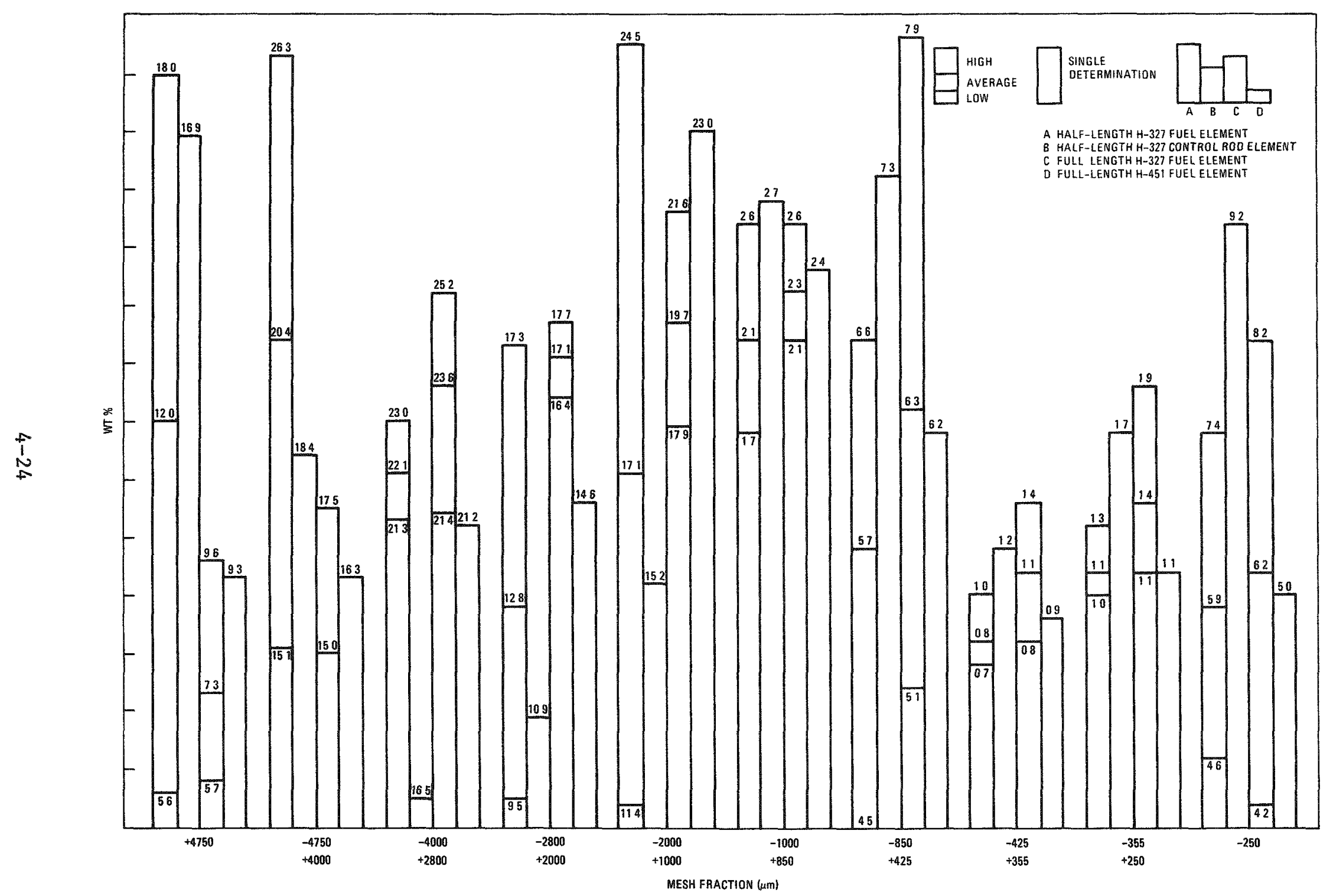

Fig. 4-3. Oversize crusher product comparison by mesh size: phase II tests 
TABLE 4-12

REPLICATE SCREEN ANALYSIS OF OVERSIZE CRUSHER PRODUCT FROM TEST UE-48: PHASE II TESTS

\begin{tabular}{|c|c|c|c|c|c|c|c|c|c|c|}
\hline \multirow[b]{2}{*}{ Sample No. } & \multicolumn{10}{|c|}{ Wt \% of Screened Fractions } \\
\hline & $+4750 \mu \mathrm{m}$ & $\begin{array}{l}-4750 \\
+4000 \mu \mathrm{m}\end{array}$ & $\begin{array}{l}-4000 \\
+2800 \mu \mathrm{m}\end{array}$ & $\begin{array}{l}-2800 \\
+2000 \mu \mathrm{m}\end{array}$ & $\begin{array}{l}-2000 \\
+1000 \mu \mathrm{m}\end{array}$ & $\begin{array}{l}-1000 \\
+850 \mu \mathrm{m}\end{array}$ & $\begin{array}{l}-850 \\
+425 \mu \mathrm{m}\end{array}$ & $\begin{array}{l}-425 \\
+355 \mu \mathrm{m}\end{array}$ & $\begin{array}{l}-355 \\
+250 \mu \mathrm{m}\end{array}$ & $-250 \mu \mathrm{m}$ \\
\hline
\end{tabular}

Half-Length Standard H-327 Unfueled Graphite Fuel Element

\begin{tabular}{|c|c|c|c|c|c|c|c|c|c|c|}
\hline 1 & 17.3 & 25.7 & 21.1 & 9.4 & 11.5 & 1.7 & 5.0 & 0.8 & 1.1 & 6.4 \\
\hline 2 & 18.6 & 26.6 & 21.4 & 9.4 & 11.3 & 1.7 & 4.1 & 0.7 & 0.9 & 5.3 \\
\hline 3 & 18.3 & 26.6 & 21.4 & 9.6 & 11.3 & 1.6 & 4.3 & 0.7 & 0.9 & 5.3 \\
\hline Mean & 18.1 & 26.3 & 21.3 & 9.5 & 11.4 & 1.7 & 4.5 & 0.7 & 1.0 & 5.7 \\
\hline Range & 1.3 & 0.9 & 0.3 & 0.2 & 0.2 & 0.1 & 0.9 & 0.1 & 0.2 & 1.1 \\
\hline $\begin{array}{l}\text { Average } \\
\text { Deviation } \\
\text { From Mean }\end{array}$ & 0.5 & 0.4 & 0.1 & 0.1 & 0.1 & 0 & 0.4 & 0 & 0.1 & 0.5 \\
\hline
\end{tabular}

\begin{tabular}{l|l|l|l|l|l|l|l|l|l|l|l}
\hline & \multicolumn{8}{|c}{ Cumulative Wt \% Less Than } \\
\cline { 2 - 5 } & $+4750 \mu \mathrm{m}$ & $-4750 \mu \mathrm{m}$ & $-4000 \mu \mathrm{m}$ & $-2800 \mu \mathrm{m}$ & $-2000 \mu \mathrm{m}$ & $-1000 \mu \mathrm{m}$ & $-850 \mu \mathrm{m}$ & $-425 \mu \mathrm{m}$ & $-355 \mu \mathrm{m}$ & $-250 \mu \mathrm{m}$ \\
\hline
\end{tabular}

Half-Length Standard H-327 Unfueled Graphite Fuel Element

\begin{tabular}{|c|c|c|c|c|c|c|c|c|c|c|}
\hline 1 & 100.0 & 82.7 & 57.0 & 35.9 & 26.5 & 15.0 & 13.3 & 8.3 & 7.5 & 6.4 \\
\hline 2 & 100.0 & 81.4 & 54.8 & 33.4 & 24.0 & 12.7 & 11.0 & 6.9 & 6.2 & 5.3 \\
\hline 3 & 100.0 & 81.7 & 55.1 & 33.7 & 24.1 & 12.8 & 11.2 & 6.9 & 6.2 & 5.3 \\
\hline Mean & 100.0 & 81.9 & 55.6 & 34.3 & 24.9 & 13.5 & 11.8 & 7.4 & 6.6 & 5.7 \\
\hline Range & 0 & 1.3 & 2.2 & 2.5 & 2.5 & 2.3 & 2.3 & 1.4 & 1.3 & 1.1 \\
\hline $\begin{array}{l}\text { Average } \\
\text { Deviation } \\
\text { From Mean }\end{array}$ & 0 & 0.5 & 0.9 & 1.0 & 1.1 & 1.0 & 1.0 & 0.6 & 0.6 & 0.5 \\
\hline
\end{tabular}




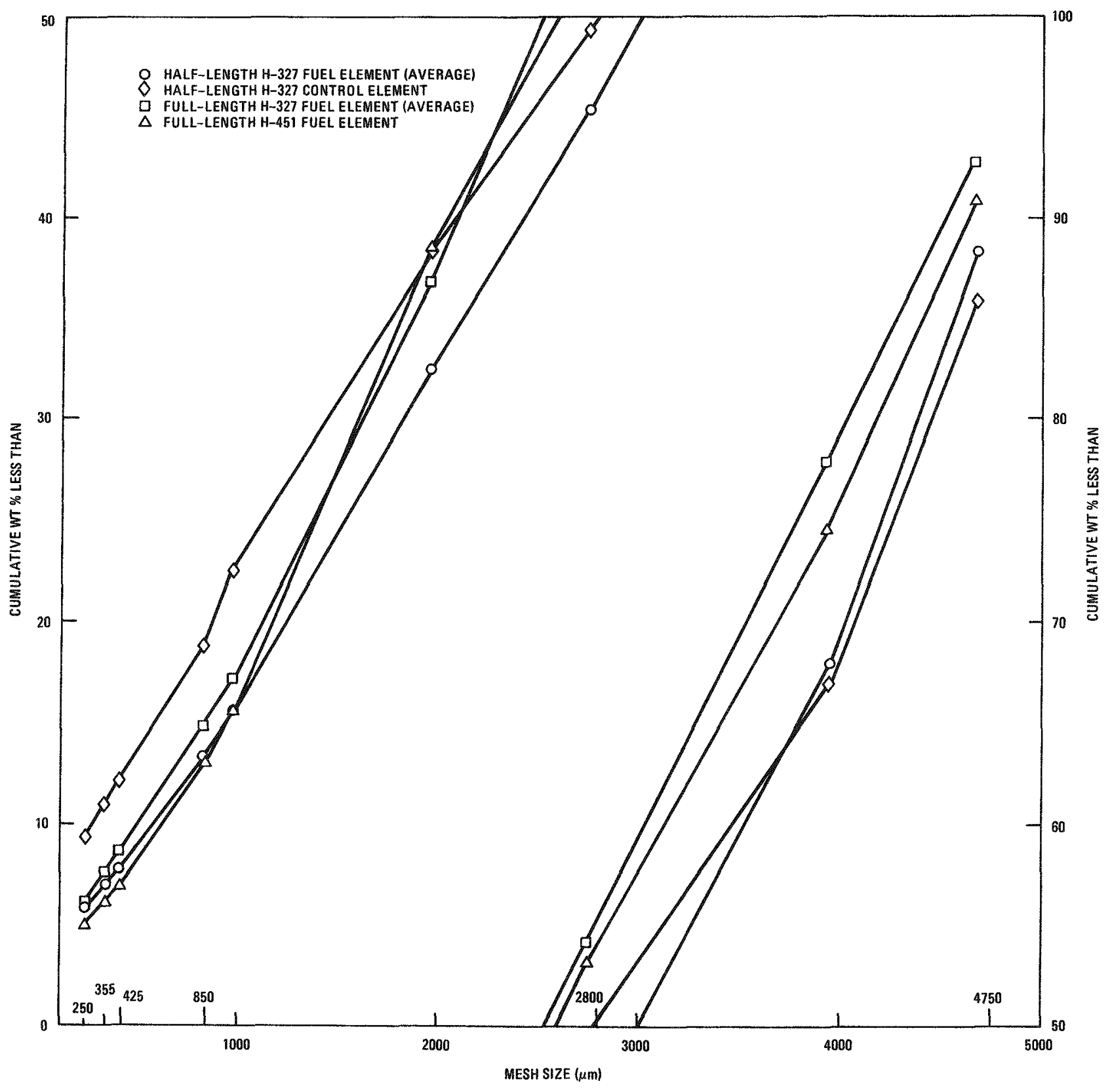

Fig. 4-4. Oversize crusher product comparison by cumulative weight percent: phase II tests 
TABLE 4-13

OVERSIZE CRUSHER PRODUCT SIZE DISTRIBUTIONS (CUMULATIVE WT \%): PHASE II TESTS

\begin{tabular}{|c|c|c|c|c|c|c|c|c|c|c|}
\hline \multirow[b]{2}{*}{ Test No. } & \multicolumn{10}{|c|}{ Cumulative Wt \% Less Than } \\
\hline & $+4750 \mu \mathrm{m}$ & $-4750 \mu \mathrm{m}$ & $-4000 \mu \mathrm{m}$ & $-2800 \mu \mathrm{m}$ & $-2000 \mu \mathrm{m}$ & $-1000 \mu \mathrm{m}$ & $-850 \mu \mathrm{m}$ & $-425 \mu \mathrm{m}$ & $-355 \mathrm{Hm}$ & $-250 \mu \mathrm{m}$ \\
\hline \multicolumn{11}{|c|}{ Half-Length Standard H-327 Unfueled Graphite Fuel Elements } \\
\hline UE-46 & 100.0 & 94.4 & 79.3 & 56.4 & 40.1 & 15.6 & 13.0 & 6.4 & 5.6 & 4.6 \\
\hline $\mathrm{UE}-47$ & 100.0 & 87.7 & 67.8 & 44.8 & 33.2 & 17.7 & 15.6 & 9.7 & 8.7 & 7.4 \\
\hline UE-48 & 100.0 & 81.9 & 55.6 & 34.3 & 24.9 & 13.5 & 11.8 & 7.4 & 6.6 & 5.7 \\
\hline Mean & 100.0 & 88.0 & 67.6 & 45.5 & 32.7 & 15.6 & 13.5 & 7.8 & 7.0 & 5.9 \\
\hline Range & 0 & 12.5 & 23.7 & 23.1 & 15.2 & 4.2 & 3.8 & 3.3 & 3.1 & 2.8 \\
\hline $\begin{array}{l}\text { Average } \\
\text { Deviation } \\
\text { From Mean }\end{array}$ & 0 & 4.3 & 8.0 & 7.9 & 5.2 & 1.4 & 1.4 & 1.2 & 1.2 & 1.0 \\
\hline
\end{tabular}

Half-Length H-327 Unfueled Graphite Control Rod Element

\begin{tabular}{|c|c|c|c|c|c|c|c|c|c|c|}
\hline $\mathrm{UE}-49$ & 100.0 & 85.6 & 66.6 & 49.6 & 38.3 & 22.6 & 19.8 & 12.3 & 11.1 & 9.5 \\
\hline \multicolumn{11}{|c|}{ Ful1-Length Standard H-327 Unfueled Graphite Fuel Elements } \\
\hline $\mathrm{UE}-52 \mathrm{~B}$ & 100.0 & 90.4 & 75.0 & 50.7 & 34.3 & 16.4 & 14.3 & 8.4 & 7.4 & 6.1 \\
\hline $\mathrm{UE}-53$ & 100.0 & 94.3 & 82.3 & 60.9 & 43.6 & 22.0 & 19.4 & 11.5 & 10.1 & 8.2 \\
\hline $\mathrm{UE}-54$ & 100.0 & 93.3 & 75.8 & 50.6 & 32.9 & 13.3 & 11.2 & 6.1 & 5.3 & 4.2 \\
\hline Mean & 100.0 & 92.7 & 77.7 & 54.1 & 36.9 & 17.2 & 15.0 & 8.7 & 7.6 & 6.2 \\
\hline Range & 0 & 3.9 & 7.3 & 10.3 & 10.7 & 8.7 & 8.2 & 5.4 & 4.8 & 4.0 \\
\hline $\begin{array}{l}\text { Average } \\
\text { Deviation } \\
\text { From Mean }\end{array}$ & 0 & 1.5 & 3.1 & 4.6 & 4.4 & 3.2 & 3.0 & 1.9 & 1.7 & 1.4 \\
\hline \multicolumn{11}{|c|}{ Ful1-Length Standard H-451 Unfueled Graphite Fuel Element } \\
\hline UE-55 & 100.0 & 90.7 & 74.4 & 53.2 & 38.6 & 15.6 & 13.2 & 7.0 & 6.1 & 5.0 \\
\hline \multicolumn{11}{|c|}{ Summary of All Tests } \\
\hline Mean & 100.0 & 89.8 & 72.1 & 50.2 & 35.7 & 17.1 & 14.8 & 8.6 & 7.6 & 6.3 \\
\hline Range & 0 & 12.5 & 26.7 & 26.6 & 18.7 & 9.3 & 8.6 & 6.2 & 5.8 & 5.3 \\
\hline
\end{tabular}


1. The oversize crusher product from crushing half-length control rod elements differed significantly from that of half-length fuel elements in only the $-4000+2800 \mu \mathrm{m}$ mesh fraction. In this fraction, the quantity was less in the control rod product (16.5\%) than in the fuel element product $(21.3 \% \mathrm{minimum})$.

2. The oversize crusher product obtained from crushing full-length H-451 graphite fuel elements differed significantly from that of full-length $\mathrm{H}-357$ graphite fuel elements as follows:

a. The quantity of $-2800+2000 \mu \mathrm{m}$ mesh material was less in the $\mathrm{H}-451$ graphite product $(14.6 \%)$ than in any of the $\mathrm{H}-357$ graphite products ( $16.4 \%$ minimum).

b. The quantity of $-2000+1000 \mu \mathrm{m}$ mesh material was greater in the $\mathrm{H}-451$ graphite product $(23.0 \%)$ than in any of the $\mathrm{H}-357$ graphite products $(21.6 \%$ maximum).

c. The ranges of values for all mesh fractions overlapped sufficiently for the half- and full-size H-357 graphite fuel element oversize crusher products, indicating no difference in these products.

\subsubsection{Composite Screener and Oversize Crusher Product Size} Distributions. The total product size distribution of the system was estimated by combining the percentages of each size fraction of screener and oversize crusher product (Tables $4-8$ and 4-11) in proportion to the quantity found in the total product (Table 4-7). The resulting composites are shown in Table 4-14, and results are compared in Fig. 4-5. Significant differences shown by these data are

1. The composite product obtained from crushing half-length control rod elements differed significantly from that from half-length 
TABIE $4-14$

COMPOSITE SCREENER AND OVERSIZE CRUSHER PRODUCT SIZE DISTRIBUTIONS: PHASE II TESTS

\begin{tabular}{|c|c|c|c|c|c|c|c|c|c|c|}
\hline \multirow[b]{2}{*}{ Test No. } & \multicolumn{10}{|c|}{ Wt \% of Screened Fractions } \\
\hline & $+4750 \mu \mathrm{m}$ & $\begin{array}{l}-4750 \\
+4000 \mu \mathrm{m}\end{array}$ & $\begin{array}{l}-4000 \\
+2800 \mu \mathrm{m}\end{array}$ & $\begin{array}{l}-2800 \\
+2000 \mu \mathrm{m}\end{array}$ & $\begin{array}{l}-2000 \\
+1000 \mu \mathrm{m}\end{array}$ & $\begin{array}{l}-1000 \\
+850 \mu \mathrm{m}\end{array}$ & $\begin{array}{l}-850 \\
+425 \mu \mathrm{m}\end{array}$ & $\begin{array}{l}-425 \\
+355 \mu \mathrm{m}\end{array}$ & $\begin{array}{l}-355 \\
+250 \mu \mathrm{m}\end{array}$ & $-250 \mu \mathrm{m}$ \\
\hline
\end{tabular}

\begin{tabular}{|c|c|c|c|c|c|c|c|c|c|c|}
\hline \multicolumn{11}{|c|}{ Half-Length Standard H-327 } \\
\hline UE-46 & 1.2 & 10.9 & 36.8 & 14.5 & 15.8 & 2.2 & 7.7 & 1.7 & 1.8 & 7.4 \\
\hline $\mathrm{UE}-47$ & 2.8 & 12.0 & 38.3 & 13.9 & 14.0 & 2.1 & 7.1 & 1.4 & 1.8 & 6.6 \\
\hline UE-48 & 2.3 & 10.8 & 41.6 & 16.0 & 13.8 & 1.9 & 6.2 & 1.2 & 1.4 & 4.8 \\
\hline Mean & 2.1 & 11.2 & 38.9 & 14.8 & 15.5 & 2.1 & 7.0 & 1.4 & 1.7 & 6.3 \\
\hline Range & 1.6 & 2.2 & 4.8 & 2.1 & 2.0 & 0.3 & 1.5 & 0.5 & 0.4 & 2.6 \\
\hline $\begin{array}{l}\text { Average } \\
\text { Deviation } \\
\text { From Mean }\end{array}$ & 0.6 & 0.5 & 1.8 & 0.8 & 1.2 & 0.1 & 0.5 & 0.2 & 0.2 & 1.0 \\
\hline \multicolumn{11}{|c|}{ Half-Length H-327 Unfueled Graphite Control Rod Element } \\
\hline UE-49 & 2.2 & 13.0 & 39.4 & 15.6 & 13.7 & 2.0 & 6.0 & 1.1 & 1.6 & 5.4 \\
\hline \multicolumn{11}{|c|}{ Full-Length Standard H-327 Unfueled Graphite Fuel Elements } \\
\hline UE-52B & 1.9 & 9.7 & 39.1 & 15.8 & 14.4 & 2.1 & 6.9 & 1.4 & 1.9 & 6.8 \\
\hline UE-53 & 1.7 & 9.2 & 35.9 & 16.9 & 17.4 & 2.5 & 7.4 & 1.3 & 1.5 & 6.2 \\
\hline $\mathrm{UE}-54$ & 1.5 & 8.7 & 40.1 & 17.4 & 15.5 & 2.0 & 6.5 & 1.2 & 1.5 & 5.6 \\
\hline Mean & 1.7 & 9.2 & 38.4 & 16.7 & 15.8 & 2.2 & 6.9 & 1.3 & 1.6 & 6.2 \\
\hline Range & 0.4 & 1.0 & 4.2 & 1.6 & 1.9 & 0.5 & 0.9 & 0.2 & 0.4 & 1.2 \\
\hline $\begin{array}{l}\text { Average } \\
\text { Deviation } \\
\text { From Mean }\end{array}$ & 0.1 & 0.3 & 1.6 & 0.6 & 1.1 & 0.2 & 0.3 & 0.1 & 0.2 & 0.4 \\
\hline \multicolumn{11}{|c|}{ Full-Length Standard H-451 Unfueled Graphite Fuel Element } \\
\hline UE-55 & 4.4 & 13.5 & 36.0 & 13.8 & 15.7 & 2.0 & 6.7 & 1.1 & 1.5 & 5.3 \\
\hline \multicolumn{11}{|c|}{ Summary of All Tests } \\
\hline Mean & 2.2 & 11.0 & 38.4 & 15.5 & 15.0 & 2.1 & 6.8 & 1.3 & 1.6 & 6.0 \\
\hline Range & 3.2 & 4.8 & 5.7 & 3.6 & 3.6 & 0.6 & 1.7 & 0.6 & 0.5 & 2.6 \\
\hline
\end{tabular}




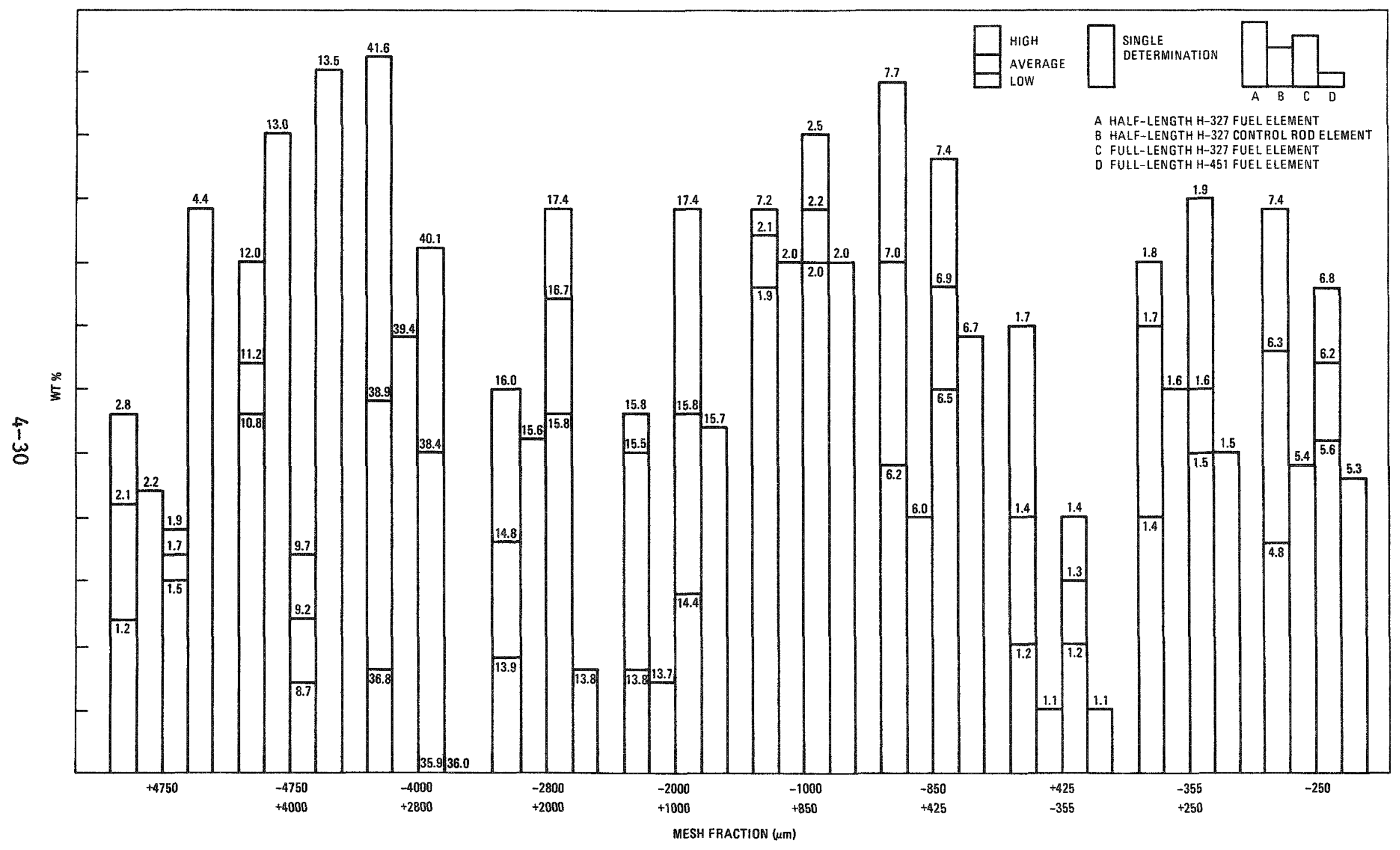

Fig. 4-5. UNIFRAME composite product comparison by mesh size: phase II tests 
fuel elements in only the $-4750+4000 \mu \mathrm{m}$ mesh fraction. In this fraction, the quantity was greater in the control rod product (13.0\%) than in any of the fuel element products (12.0\% maximum). This difference was observed in the screener products (Section 4.3.5.1.), and oversize crushing was not a factor in reducing the difference. The difference in the $-4000+2800 \mu \mathrm{m}$ mesh fraction between the two oversize crusher products (Section 4.3.5.2) was insignificant in the composite product.

2. The composite product obtained from crushing full-length $\mathrm{H}-451$ graphite fuel elements differed significantly from that from full-length $\mathrm{H}-357$ graphite fuele elements for mesh size fractions which were the same as those in the screener product (Section 4.3.5.1.). Oversize crushing had little effect on reducing these differences. The difference in the oversize crusher products of the two $-2000+1000 \mu \mathrm{m}$ mesh fractions was insignificant in the composite product.

3. Although there were no significant differences between halfand full-length $\mathrm{H}-327$ graphite fuel elements for the separate screener and oversize crusher products, the composite product indicated a significantly larger percentage of $-4750+4000 \mu \mathrm{m}$ material from the half-length elements (10.8\% minimum) than from the ful1-length elements ( $9.7 \%$ maximum).

The cumulative weight percents of materials which were less than each stated size for the composites are given in Table 4-15, and the results are compared in Fig. 4-6. Significant differences shown by this data are

1. The range of values for the composite products obtained from crushing half-length fuel elements sufficiently overlapped the values obtained from crushing half-length control rod elements, indicating no significant differences in these products. Significant differences noted in the separate screener and oversize crusher products (Tables $4-9$ and $4-13$ ) were eliminated in the combined product. 
TABLE 4-15

COMPOSITE SCREENER AND OVERSIZE CRUSHER PRODUCT SIZE DISTRIBUTIONS (CUMULATIVE WT \%): PHASE II TESTS

\begin{tabular}{|c|c|c|c|c|c|c|c|c|c|c|}
\hline \multirow[b]{2}{*}{ Test No. } & \multicolumn{10}{|c|}{ Cumulative Wt \% Less Than } \\
\hline & $+4750 \mu \mathrm{m}$ & $-4750 \mu \mathrm{m}$ & $-4000 \mu \mathrm{m}$ & $-2800 \mu \mathrm{m}$ & $-2000 \mu \mathrm{m}$ & $-1000 \mu \mathrm{m}$ & $-850 \mu \mathrm{m}$ & $-425 \mu \mathrm{m}$ & $-355 \mu \mathrm{m}$ & $-250 \mu \mathrm{m}$ \\
\hline \multicolumn{11}{|c|}{ Half-Length Standard H-327 Unfueled Graphite Fuel Elements } \\
\hline UE-46 & 100.0 & 98.8 & 87.9 & 51.1 & 36.6 & 20.8 & 18.6 & 10.9 & 9.2 & 7.4 \\
\hline $\mathrm{UE}-47$ & 100.0 & 97.3 & 85.2 & 46.9 & 33.0 & 19.0 & 16.9 & 9.8 & 8.4 & 6.6 \\
\hline UE-48 & 100.0 & 97.7 & 86.9 & 45.3 & 29.3 & 15.5 & 13.6 & 7.4 & 6.2 & 4.8 \\
\hline Mean & 100.0 & 97.9 & 86.7 & 47.8 & 33.0 & 18.4 & 16.4 & 9.4 & 7.9 & 6.3 \\
\hline Range & 0 & 1.5 & 2.7 & 5.8 & 6.3 & 5.3 & 5.0 & 3.5 & 3.0 & 2.6 \\
\hline $\begin{array}{l}\text { Average } \\
\text { Deviation } \\
\text { From Mean }\end{array}$ & 0 & 0.6 & 1.0 & 2.2 & 2.4 & 2.0 & 1.8 & 1.3 & 1.2 & 1.0 \\
\hline \multicolumn{11}{|c|}{ Half-Length H-327 Unfueled Graphite Control Rod Element } \\
\hline UE-49 & 100.0 & 97.8 & 84.8 & 45.4 & 29.8 & 16.1 & 14.1 & 8.1 & 7.0 & 5.4 \\
\hline \multicolumn{11}{|c|}{ Full-Length Standard H-327 Unfueled Graphite Fuel Elements } \\
\hline UE-52B & 100.0 & 98.1 & 88.4 & 49.3 & 33.5 & 19.1 & 17.0 & 10.1 & 8.7 & 6.8 \\
\hline UE-53 & 100.0 & 98.3 & 89.1 & 53.2 & 36.3 & 18.9 & 16.4 & 9.0 & 7.7 & 6.2 \\
\hline $\mathrm{UE}-54$ & 100.0 & 98.5 & 89.8 & 49.7 & 32.3 & 16.8 & 14.8 & 8.3 & 7.1 & 5.6 \\
\hline Mean & 100.0 & 98.3 & 89.1 & 50.7 & 34.0 & 18.3 & 16.1 & 9.1 & 7.8 & 6.2 \\
\hline Range & 0 & 0.4 & 1.4 & 3.9 & 4.0 & 2.3 & 2.2 & 1.8 & 1.6 & 1.2 \\
\hline $\begin{array}{l}\text { Average } \\
\text { Deviation } \\
\text { From Mean }\end{array}$ & 0 & 0.1 & 0.5 & 1.6 & 1.5 & 1.0 & 0.8 & 0.6 & 0.6 & 0.4 \\
\hline \multicolumn{11}{|c|}{ Ful1-Length Standard $\mathrm{H}-451$ Unfueled Graphite Fuel Element } \\
\hline $\mathrm{UE}-55$ & 100.0 & 95.6 & 82.1 & 46.1 & 32.3 & 16.6 & 14.6 & 7.9 & 6.8 & 5.3 \\
\hline \multicolumn{11}{|c|}{ Summary of All Tests } \\
\hline Mean & 100.0 & 97.8 & 86.8 & 48.4 & 32.9 & 17.8 & 15.8 & 8.9 & 7.6 & 6.0 \\
\hline Range & 0 & 3.2 & 7.7 & $7 . .9$ & 7.3 & 5.3 & 5.0 & 3.5 & 3.0 & 2.6 \\
\hline
\end{tabular}




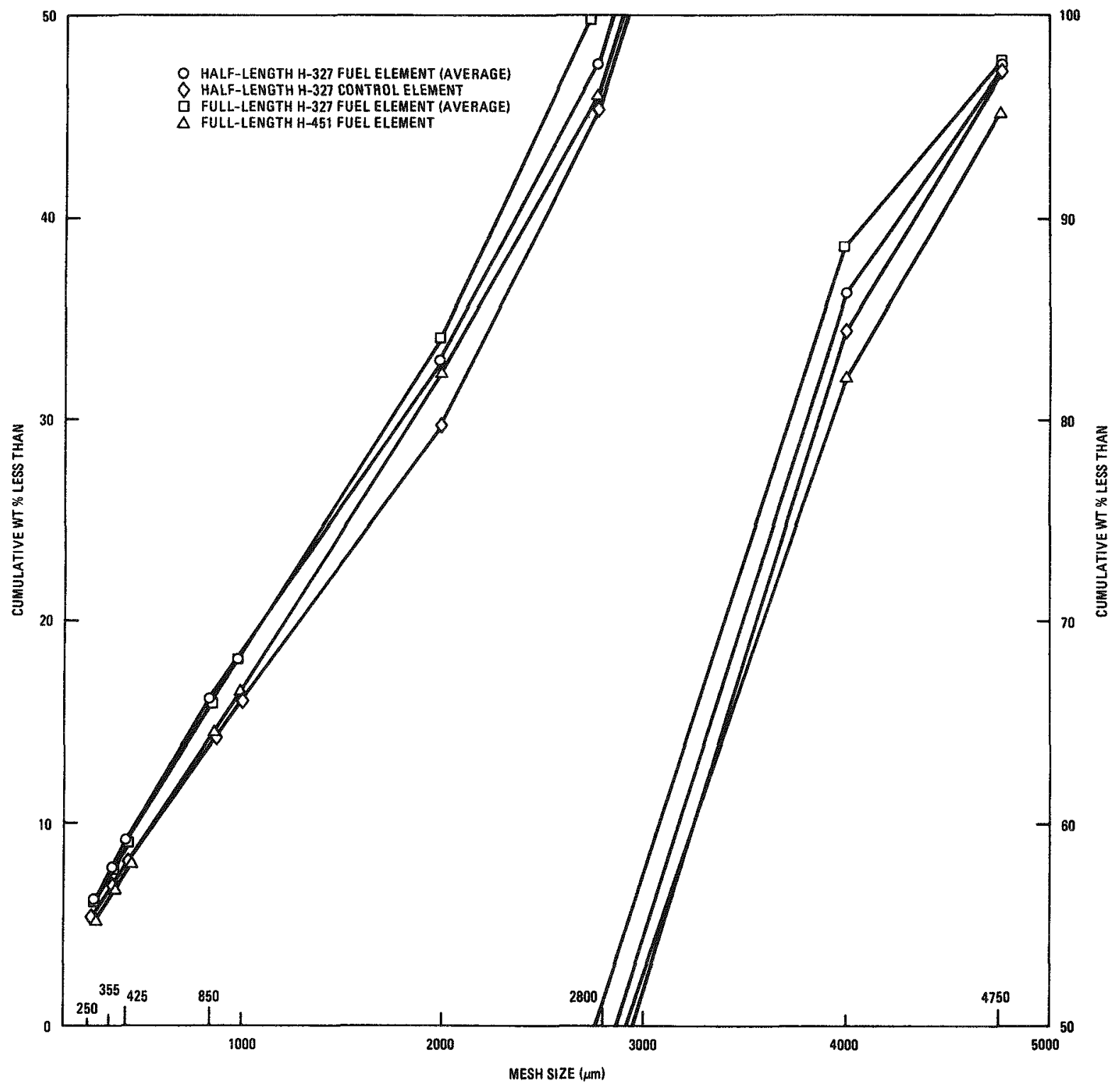

Fig. 4-6. UNIFRAME composite product comparison by cumulative weight percent: phase II tests 
2. The composite product obtained from crushing full-length $\mathrm{H}-451$ graphite fuel elements differed significantly in the same areas as in the screener products from that from the full-1ength $\mathrm{H}-357$ graphite fuel elements (Section 4.3.5.1). The oversize crusher products, which showed no significant differences, had little effect on reducing the differences in the screener products.

3. The ranges of values for the composite products obtained from crushing half- and full-1ength H-327 graphite fuel elements sufficiently overlapped, indicating no significant differences in these products.

4.3.5.4. UNIFRAME Product: General Conclusions. Although variations in the quantities of individual mesh-size fractions of materials will occur for the different types of elements crushed, the cumulative weight percents of material which is less than the stated size will not be significantly different in UNIFRAME product obtained from crushing any type of H-357 graphite element. The products obtained from crushing H-451 graphite elements, however, will be somewhat coarser.

4.3.5.5. Comparison of Composite Screener and Oversize Crusher Products With Tertiary Crusher Products. To estimate the changes in the tertiary crusher product effected by screening and oversize crushing, a comparison was made of the average tertiary crusher product size distribution obtained in the phase II shakedown tests (Table 4-2), the average composite product size distribution calculated from the phase II test results (Table 4-15), and the average tertiary crusher product size distribution obtained in the phase I tests. These results are shown in Fig. 4-7.

Since the ranges of values for these results overlapped (not shown in Fig. 4-7), significant differences could not be clearly established. However, certain trends do appear. A comparison of the composite system product with the phase I tertiary crusher product shows a tendency for 


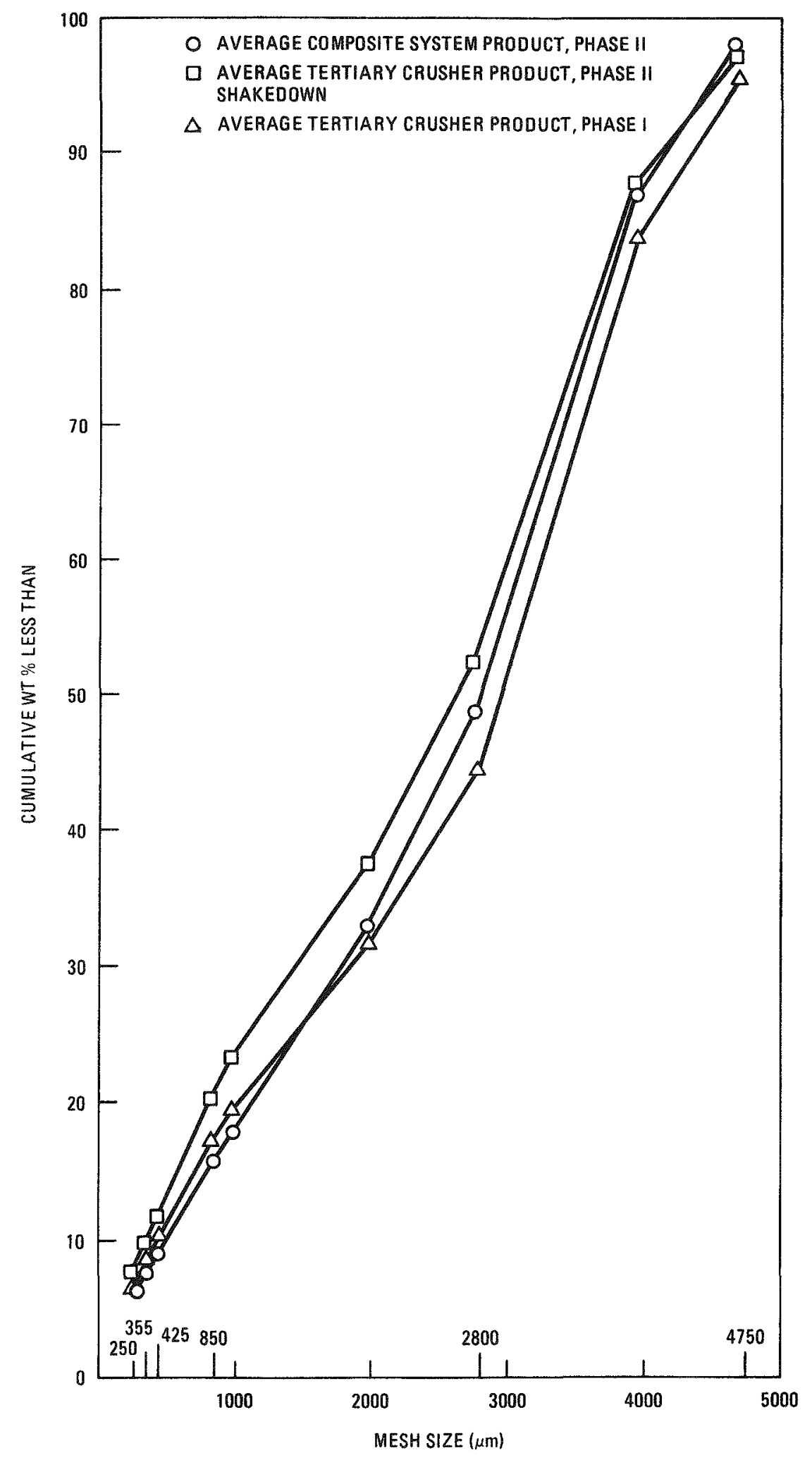

Fig. 4-7. Size distributions of products from tertiary crushing and UNIFRAME system 
increased fineness in the composite product. This can be assumed to be from the effects of oversize crushing. Comparison of the composite system product with the phase II shakedown tertiary crusher product, however, shows an opposite tendency. That is, the tertiary crusher product tends to be finer. Since the shakedown tests were made with partially drilled fuel elements (i.e., more solid graphite sections), this effect may be caused by finer crushing of the more solid graphite. This is borne out by the increased times required to crush the partially drilled elements (Tables 4-1 and 4-6) and may be an indication that a finer product and longer crushing times will result from crushing fuel-loaded elements (the refore more solid) than was observed with the unloaded elements. In any event, the effect of oversize crushing on the tertiary crusher product size distribution may be minimal.

\subsubsection{Comparison of Crushed Product with Primary Bumer Feed Require-} ments. The cumulative weight percents of material less than the stated size obtained from the composite screener and oversize crusher products were calculated with the addition of 17 wt \% $-850-\mu \mathrm{m}$ fuel particles and are given in Table 4-16. These results are compared with estimated primary burner feed size distribution requirements in Fig. 4-8. From these results it can be ssen that

1. The "acceptable" burner feed curve lies within the ranges of the results for the UNIFRAME product.

2. The entire UNIFRAME product range is consistently within the "acceptable" limits for product greater than $\sim 4500 \mu \mathrm{m}$ mesh.

3. The Iower range of UNIFRAME product results is not within the "acceptable" limits for product less than $\sim 4500 \mu \mathrm{m}$ mesh.

4. The higher range of UNIFRAME product results is consistently within the "acceptable" burner feed limits. 
TABLE $4-16$

SCREENER AND OVERSIZE CRUSHER PRODUCT SIZE DISTRIBUTIONS WITH $17 \%$ FUEL PARTICLES $(<850 \mu \mathrm{m})$ ADDED: PHASE II TESTS

\begin{tabular}{l|c|c|c|c|c|c|c}
\hline Test No. & $+4750 \mu \mathrm{m}$ & $-4750 \mu \mathrm{m}$ & $-4000 \mu \mathrm{m}$ & $-2800 \mu \mathrm{m}$ & $-2000 \mu \mathrm{m}$ & $-1000 \mu \mathrm{m}$ & $-850 \mu \mathrm{m}$ \\
\hline \multicolumn{6}{c}{ Half-Length Standard H-327 Unfueled Graphite Fuel Elements } \\
\hline UE-46 & 100.0 & 99.0 & 90.0 & 59.4 & 47.4 & 34.3 & 32.4 \\
UE-47 & 100.0 & 97.6 & 87.7 & 55.9 & 44.4 & 32.8 & 31.0 \\
UE-48 & 100.0 & 98.1 & 89.1 & 54.6 & 41.3 & 29.9 & 28.3 \\
Mean & 100.0 & 98.2 & 88.9 & 56.6 & 44.4 & 32.3 & 30.6 \\
Range & 0 & 1.4 & 2.3 & 4.8 & 6.1 & 4.4 & 4.1 \\
\hline
\end{tabular}

Half-Length H-327 Unfueled Control Rod Element

\begin{tabular}{l|c|c|c|c|c|c|c}
\hline UE-49 & 100.0 & 98.2 & 87.4 & 54.7 & 41.7 & 30.4 & 28.7 \\
\hline \multicolumn{6}{c}{ FulI-Length Standard H-327 Unfueled Graphite Fuel Elements } \\
\hline UE-52B & 100.0 & 98.4 & 90.4 & 57.9 & 44.8 & 32.8 & 31.1 \\
UE-53 & 100.0 & 98.6 & 90.9 & 61.2 & 47.1 & 32.7 & 30.6 \\
UE-54 & 100.0 & 98.8 & 91.5 & 58.2 & 43.8 & 30.9 & 29.3 \\
Mean & 100.0 & 98.6 & 90.9 & 59.1 & 45.2 & 32.1 & 30.3 \\
Range & 0 & 0.4 & 1.1 & 3.3 & 3.3 & 1.9 & 1.8 \\
\hline
\end{tabular}

Full-Length Standard H-451 Unfueled Graphite Fuel Elements

\begin{tabular}{l|c|c|c|c|c|c|c}
\hline UE-55 & 100.0 & 96.3 & 85.1 & 55.3 & 43.8 & 30.8 & 29.1 \\
\hline Mean & 100.0 & 98.1 & 89.0 & 57.2 & 44.3 & 31.8 & 30.1 \\
Range & 0 & 2.7 & 6.4 & 6.6 & 6.1 & 4.4 & 4.1 \\
\hline
\end{tabular}




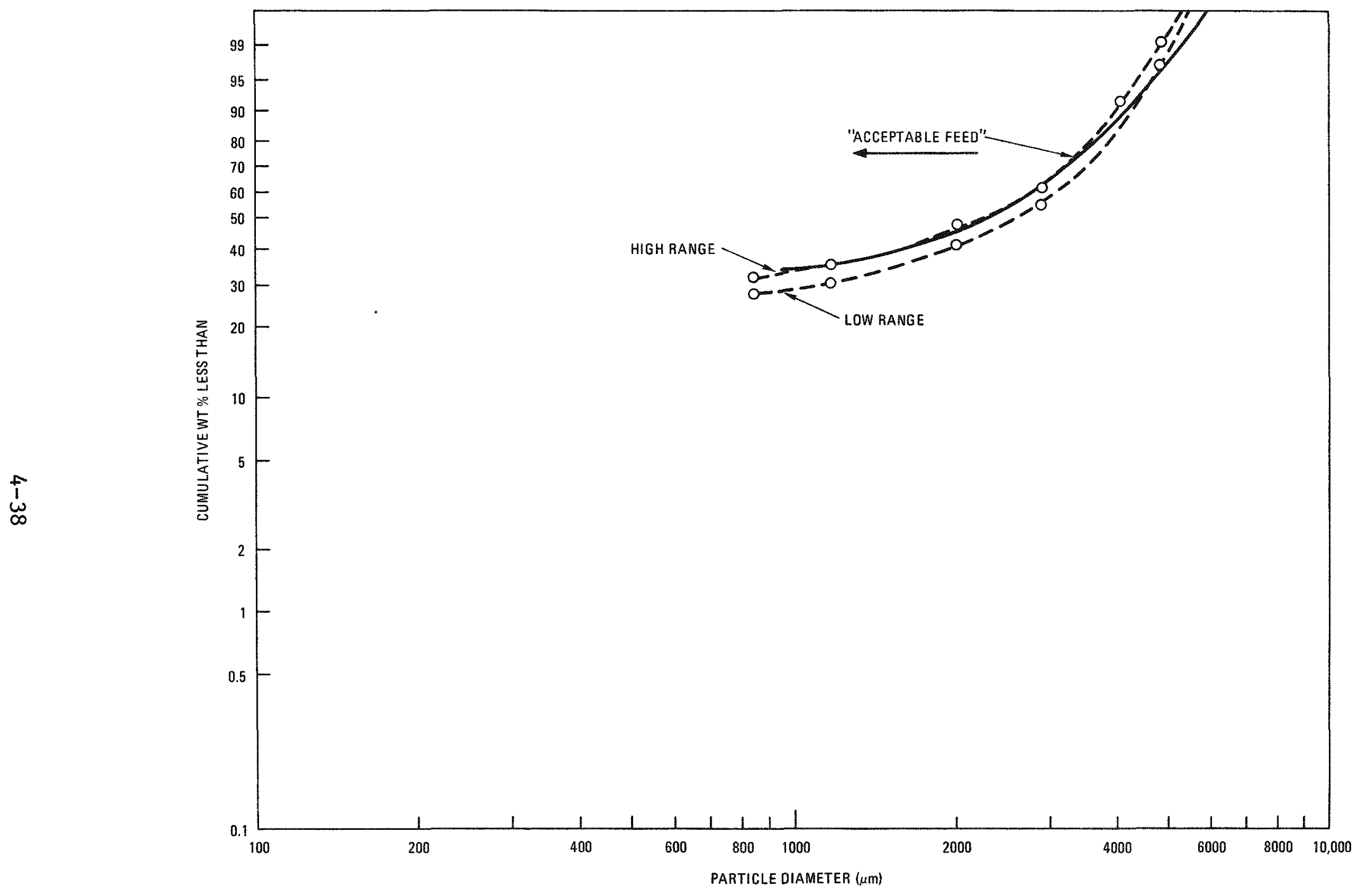

Fig. 4-8. Comparison of UNIFRAME composite high and low valves with those for "acceptable" burner feed 


\subsection{PHASE II ACCEPTANCE CRITERIA}

The degree of success of each phase of UNIFRAME testing was based upon meeting certain requirements of the design criterion (see appendix). Acceptance criteria, defined in the activity plan, are based on demonstrations of performance and quantified data which prove that the requirements of the design criterion have been met. The acceptance criteria applicable to the UNIFRAME system for the phase II test program are described below, and the results of the tests are given.

\subsubsection{Material Holdup: $50.5 \%$ of Throughput}

Cleaning out of the system at the end of the phase II tests enabled recovery of $0.26 \%$ of the throughput as holdup on the various components of the system. The total MUF after clean-out was $0.19 \%$ of the throughput. Assuming that the MUF was also holdup, the total holdup is $0.45 \%$ (Table 4-5). The data indicate that achieving a material holdup of $<0.5 \%$ is possible for the current design of the UNIFRAME system. Identification of the holdup areas in phase II and future tests will provide a basis for design modifications which will further reduce holdup.

\subsubsection{Throughput Rate: One Fuel Element in $\leq 15$ Min}

The results of the phase II tests indicate a normal crushing time of $3 \mathrm{~min}$ for a full-length H-327 graphite fuel element and $~ 5 \mathrm{~min}$ for a fulllength H-451 graphite fuel element. Temporary material holdup in the primary and secondary crushers resulted in reduced throughput rates and extended the crushing times to up to $\sim 7 \mathrm{~min}$ (Table 4-6). The data indicate that a throughput rate of one fuel element in $\leq 15 \mathrm{~min}$ is possible in the UNIFRAME system as presently designed. Observations made during the phase II tests indicate that charging one fuel element every 5 min with a cleanout period of $\sim 15 \mathrm{~min}$ at the end of a campaign or batch may be feasible. 


\subsubsection{Crushed Material Confinement (Excluding Dusts): 100\% to Crushing and Screening Cavities}

Observations of equipment through viewports and open ventilation areas during the phase II tests revealed no material bypass of the crushing and screening cavities; $99.81 \%$ of the material was accounted for. The data and observations indicate that confining $100 \%$ of the material to the crushing and screening cavities is possible with the current design of the UNIFRAME system.

\subsubsection{Crushed Product: $\leq 4750-\mu \mathrm{m}$ Ring Size with a Size Distribution Suitable for Primary Burner Feed}

The results of screen analysis of the crushed products from the phase II tests indicate that an average of $2.2 \%$ of the product will be greater than 4750- $\mu \mathrm{m}$ mesh size, with a maximum of $24.4 \%$ (found in H-451 graphite crushed product) and a minimum of $21.2 \%$ (Table 4-15). The data indicate that achieving a crushed product $\leq 4750-\mu \mathrm{m}$ ring size is not possible in the UNIFRAME system without design or operating parameter changes. However, comparison of the ranges of UNIFRAME products with the "acceptable" primary bumer feed (Fig. 4-8) shows that the product consistently meets this criterion above $4500 \mu \mathrm{m}$. The results also indicate that the lower range of the UNIFRARE product is not within the "acceptable" limits for primary burner feed below $4500 \mu \mathrm{m}$ (Fig. 4-8), and achieving a crushed product which consistently meets the primary burner feed size distribution requirements is not possible in the present UNIFRAME system without design or operating parameter changes.

Meeting both these necessitatements may necessitate redesign or replacement of the oversize crusher and/or reduction of the tertiary crusher gap. These changes could result in overcrushing and particle breakage in excess of the specified maximums, forcing a trade-off with burner feed requirements. The $+4750-\mu$ m material was observed in the phase 
I tests of the oversize crusher, and the decision at that time was to reassess the requirement that the material be less than $+4750-\mu \mathrm{m}$ until further testing can determine the extent of particle breakage at current operating parameters and after tests in the $0.4-\mathrm{m}$ bumer further quantify the actual feed size requirements. It is not planned to make changes to the UNIFRAME system to meet this criterion until primary burner feed requirements are demonstrated and the extent of particle breakage is established.

\subsubsection{Dust Confinement: $100 \%$ to Ventilation Enclosure}

The complete ventilation enclosure was not installed during the phase II tests, and therefore observation of the primary and secondary crushing operations was not possible. The installed ventilation enclosure components did not display a tendency to allow dust to escape. The material balances supported this observation, with $99.81 \%$ of the material accounted for. The data and observations indicate that achieving confinement of $100 \%$ of the dust to the ventilation enclosure is possible with the UNIFRAME system. Further data were obtained in the phase III tests using the more easily detected radioactive fuel materials. 


\section{UNIFRAME SCRAP GRAPHITE CRUSHING TESTS}

\subsection{INTRODUCTION}

Because of the high cost and limited availability of scrap HTGR fuel elements, a large quantity of anode butt scrap graphite was purchased to provide crushed graphite feed for primary bumer testing. This graphite, which was crushed to use as burner feed, was also used to obtain further operating and crushing experience with the UNIFRAME fuel element size reduction system prior to processing of loaded fuel elements.

\subsection{SHAKEDOWIJ TESTS}

Three crushing tests (SCRAP-1 through SCRAP-3) were used to shake down the UNIFRAIE system with scrap anode butt graphite. This graphite had random shapes and sizes and was expected to exhibit somewhat different crushing behavior and product characteristics than the prismatic HTGR fuel elements. For comparative purposes, in the initial tests, products were separately collected from the oversize crusher and the screener and sampled, as was done in the phase II tests with HTGR fuel elements. Data on the product size distributions obtained in these tests are given in Tables 5-1 and 5-2. Figures 5-1 and 5-2 compare the screener and oversize crusher products from crushing scrap anode butt graphite and HTGR fuel elements, respectively. The screener product obtained from crushing anode graphite was not significantly different from that obtained from crushing fuel elements (Fig, 5-1). However, the anode graphite oversize crusher product was considerably finer than that from crushed fuel elements (Fig. 5-2).

Because of the generally smaller size of the charged anode graphite fragments, less primary crushing was required than for the HTGR elements, 
TABLE $5-1$

SCREENER PRODUCT SIZE DISTRIBUTIONS: ANODE BUTT SCRAP GRAPHITE

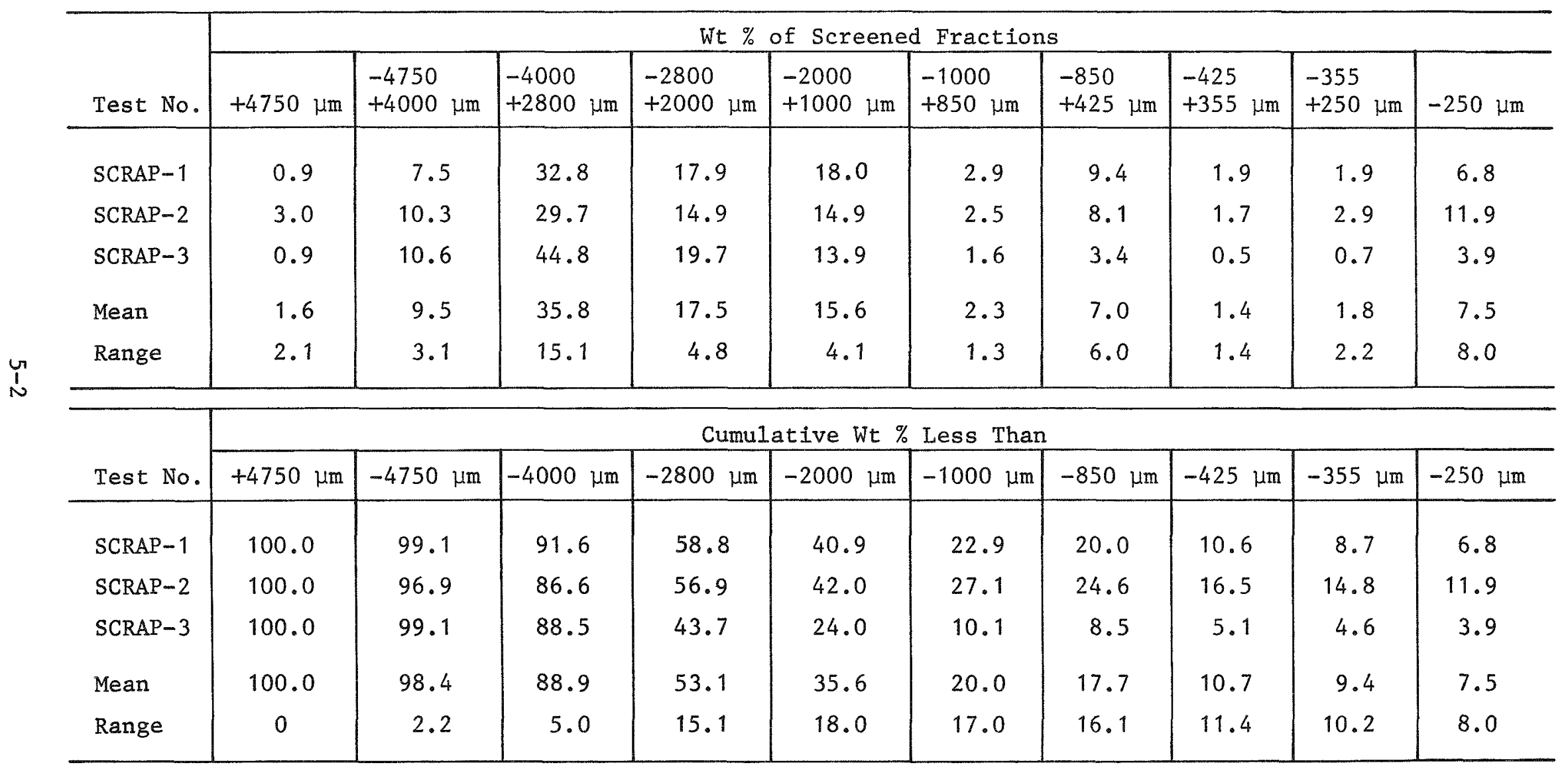


TABLE 5-2

OVERSIZE CRUSHER PRODUCT SIZE DISTRIBUTIONS: ANODE BUTT SCRAP GRAPHITE

\begin{tabular}{|c|c|c|c|c|c|c|c|c|c|c|}
\hline \multirow[b]{2}{*}{ Test No. } & \multicolumn{10}{|c|}{ Wt \% of Screened Fractions } \\
\hline & $+4750 \mu \mathrm{m}$ & $\begin{array}{l}-4750 \\
+4000 \mu \mathrm{m}\end{array}$ & $\begin{array}{l}-4000 \\
+2800 \mu \mathrm{m}\end{array}$ & $\begin{array}{l}-2800 \\
+2000 \mu \mathrm{m}\end{array}$ & $\begin{array}{l}-2000 \\
+1000 \mu \mathrm{m}\end{array}$ & $\begin{array}{l}-1000 \\
+850 \mu \mathrm{m}\end{array}$ & $\begin{array}{l}-850 \\
+425 \mu \mathrm{m}\end{array}$ & $\begin{array}{l}-425 \\
+355 \mu \mathrm{m}\end{array}$ & $\begin{array}{l}-355 \\
+250 \mu \mathrm{m}\end{array}$ & $-250 \mu \mathrm{m}$ \\
\hline SCRAP-1 & 6.5 & 7.8 & 8.1 & 9.7 & 23.8 & 4.6 & 14.9 & 2.6 & 3.2 & 18.8 \\
\hline SCRAP-2 & 11.2 & 9.1 & 11.6 & 13.3 & 25.3 & 3.6 & 10.0 & 1.7 & 2.2 & 11.8 \\
\hline SCRAP-3 & 10.4 & 10.4 & 16.0 & 15.7 & 22.9 & 2.9 & 8.5 & 1.5 & 1.9 & 9.7 \\
\hline Mean & 9.4 & 9.1 & 11.9 & 12.9 & 24.0 & 3.7 & 11.1 & 1.9 & 2.4 & 13.4 \\
\hline Range & 4.7 & 2.6 & 7.9 & 6.0 & 2.4 & 1.7 & 6.4 & 1.1 & 1.3 & 9.1 \\
\hline
\end{tabular}

\begin{tabular}{l|c|c|c|c|c|c|c|c|c|c}
\hline & \multicolumn{10}{c}{ Cumulative Wt \% Less Than } \\
\cline { 2 - 10 } Test No. & $+4750 \mu \mathrm{m}$ & $-4750 \mu \mathrm{m}$ & $-4000 \mu \mathrm{m}$ & $-2800 \mu \mathrm{m}$ & $-2000 \mu \mathrm{m}$ & $-1000 \mu \mathrm{m}$ & $-850 \mu \mathrm{m}$ & $-425 \mu \mathrm{m}$ & $-355 \mu \mathrm{m}$ & $-250 \mu \mathrm{m}$ \\
\hline \multirow{2}{*}{ SCRAP-1 } & 100.0 & 93.5 & 85.7 & 77.6 & 67.9 & 44.1 & 39.5 & 24.6 & 22.0 & 18.8 \\
SCRAP-2 & 100.0 & 88.6 & 79.5 & 67.9 & 54.6 & 29.3 & 25.7 & 15.7 & 14.0 & 11.8 \\
SCRAP-3 & 100.0 & 89.5 & 79.1 & 63.1 & 47.4 & 24.5 & 21.6 & 13.1 & 11.6 & 9.7 \\
Mean & 100.0 & 90.5 & 81.4 & 69.5 & 56.6 & 32.6 & 28.9 & 17.8 & 15.9 & 13.4 \\
Range & 0 & 4.9 & 6.6 & 14.5 & 20.5 & 19.6 & 17.9 & 11.5 & 10.4 & 9.1 \\
\hline
\end{tabular}




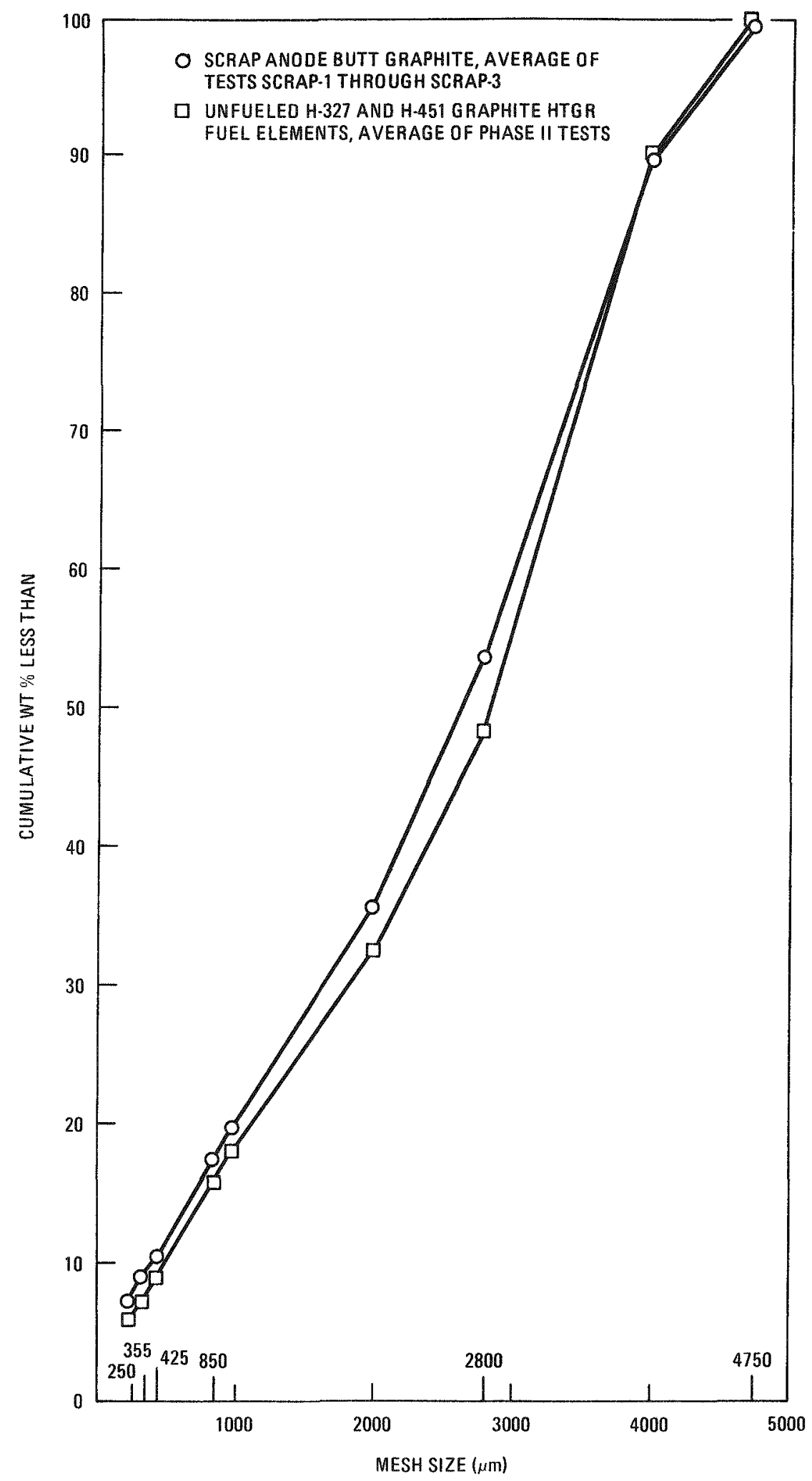

Fig. 5-1. Screener product comparison: fuel elements and scrap graphite 


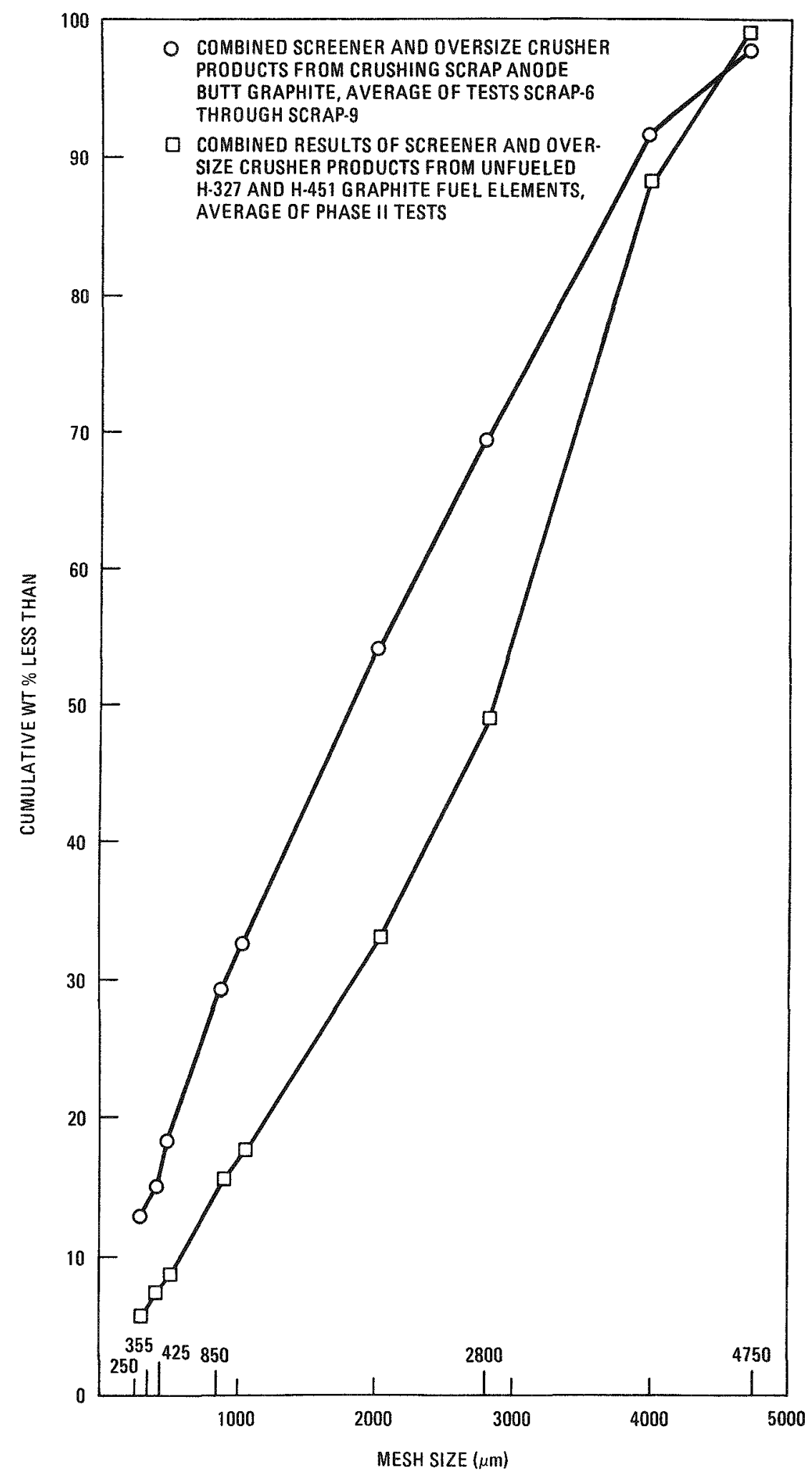

Fig. 5-2. Oversize crusher product comparison: fuel elements and scrap graphite 
and therefore primary crushing times were reduced $225 \%$ (Table 5-3). However, because the anode graphite was solid and did not contain fuel or coolant holes as the fuel elements do, the secondary crushing time was approximately doubled (Table 5-3). This increase in secondary crushing time resulted in lower loading rates on the screener, which, coupled with the finer product, improved its efficiency. The screener product increased from an average of $85.12 \%$ of the total product when crushing fuel elements to $89.44 \%$ when crushing anode graphite (Table 5-3).

\subsection{SCRAP GRAPHITE CRUSHING}

Crushing of anode graphite for primary burner feed continued with attempts to utilize the pneumatic material transport system to collect the screener and oversize crusher products in the UNIFRAME product bunker. In the initial test (SCRAP-4), the crushed product which discharged from the screener was easily transported. However, crushed product from the oversize crusher was not transported at all. This was attributed to an insufficient motive gas flow through the oversize crusher due to increased pressure drop at the oversize crusher product entry point to the transport line. This diverted the motive gas through the path of least resistance (i.e., the screener) and allowed material to salt out and completely block the oversize crusher discharge (FIg, 5-3).

Testing was continued (SCRAP-5 through SCRAP-9) to gain experience with and make further observations on screener product discharge and transport. In all tests, the screener product was successfully transported to the UNIFRAME product bunker by the pneumatic transport system. Because of the transport difficulties experienced in SCRAP-4, the oversize crusher product was separately collected as in the phase II tests and was later manually combined with the screener product for size distribution analysis (Fig. 5-4).

Data on the product size distributions obtained in these tests are given in Table 5-4. Figure 5-5 compares the size distribution of the 
TABLE 5-3

COMPARISON OF CRUSHING BEHAVIOR OF HTGR FUEL ELEMENTS AND SCRAP ANODE BUTT GRAPHITE

\begin{tabular}{|c|c|c|c|c|c|c|c|c|}
\hline \multirow[b]{2}{*}{ Test No. } & \multicolumn{4}{|c|}{$\begin{array}{l}\text { Half-Length Unfueled } \mathrm{H}-327 \\
\text { Graphite Fuel Elements }\end{array}$} & \multicolumn{4}{|c|}{ Scrap Anode Butt Graphite } \\
\hline & $U E-46$ & $U E-47$ & $U E-48$ & Avg & SCRAP-1 & SCRAP-2 & SCRAP-3 & Avg \\
\hline Total product, $\mathrm{kg}$ & 43.523 & 45.585 & 46.628 & 45.245 & 44.024 & 44.023 & 44.478 & 44.175 \\
\hline$\%$ oversize crushed & 17.40 & 16.88 & 10.35 & 14.88 & 5.17 & 11.98 & 14.54 & 10.56 \\
\hline$\%$ through screener & 82.60 & 83.12 & 89.65 & 85.12 & 94.83 & 88.02 & 85.46 & 89.44 \\
\hline Crushing time, $s$ & & & & & & & & \\
\hline Primary & 35 & 55 & 40 & 43 & 36 & 29 & 29 & 31 \\
\hline Secondary & 92 & 95 & 90 & 92 & 160 & 219 & 190 & 190 \\
\hline
\end{tabular}




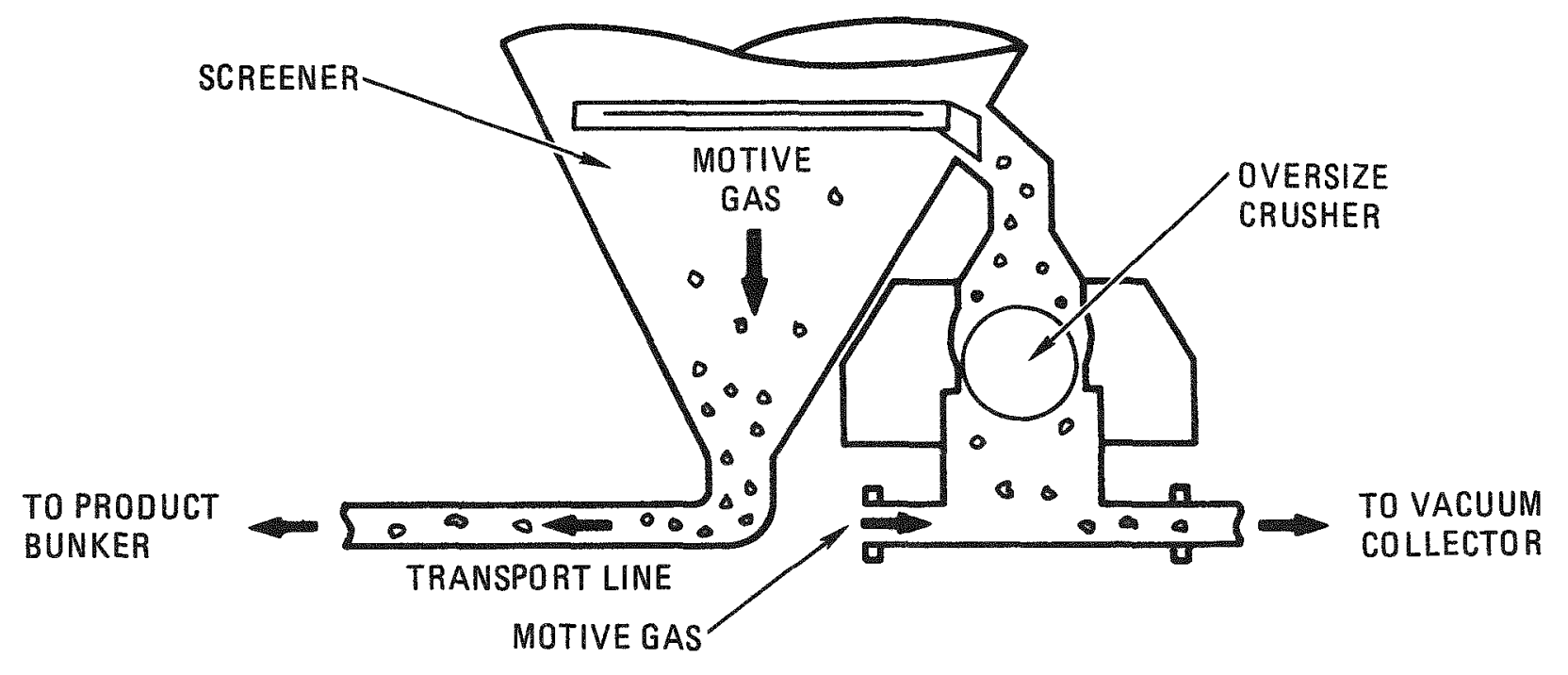

Fig. 5-3. Product transport line blockage: test SCRAP-3 


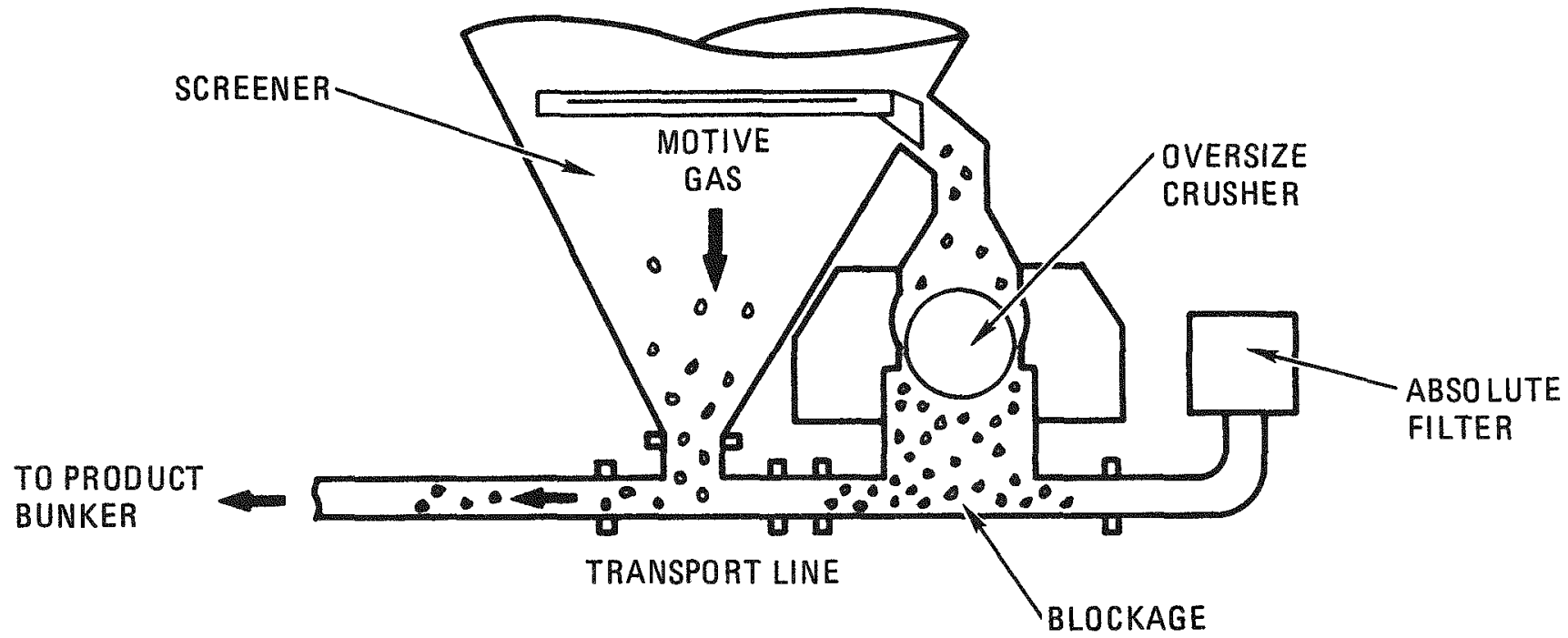

Fig. 5-4. Product transport arrangement: tests SCRAP-4 through SCRAP-9 
TABLE 5-4

PRODUCT SIZE DISTRIBUTIONS: ANODE BUTT SCRAP GRAPHITE SCREENER PRODUCT TRANSPORTED AND BLENDED WITH OVERSIZE CRUSHER PRODUCT

\begin{tabular}{|c|c|c|c|c|c|c|c|c|c|c|}
\hline \multirow[b]{2}{*}{ Test No. } & \multicolumn{10}{|c|}{ Wt $\%$ of Screened Fractions } \\
\hline & $+4750 \mu \mathrm{m}$ & $\begin{array}{l}-4750 \\
+4000 \mu \mathrm{m}\end{array}$ & $\begin{array}{l}-4000 \\
+2800 \mu \mathrm{m}\end{array}$ & $\begin{array}{l}-2800 \\
+2000 \mu \mathrm{m} \\
\end{array}$ & $\begin{array}{l}-2000 \\
+1000 \mu \mathrm{m}\end{array}$ & $\begin{array}{l}-1000 \\
+850 \mu \mathrm{m}\end{array}$ & $\begin{array}{l}-850 \\
+425 \mu \mathrm{m} \\
\end{array}$ & $\begin{array}{l}-425 \\
+355 \mu \mathrm{m}\end{array}$ & $\begin{array}{l}-355 \\
+250 \mu \mathrm{m}\end{array}$ & $-250 \mu \mathrm{m}$ \\
\hline SCRAP -4 & 3.4 & 7.5 & 26.4 & 17.7 & 21.5 & 2.8 & 8.6 & 1.5 & 2.0 & 8.5 \\
\hline SCRAP-5 & 2.8 & 5.6 & 22.3 & 15.0 & 19.5 & 3.4 & 10.6 & 2.1 & 3.3 & 15.3 \\
\hline SCRAP- 6 & 2.9 & 4.0 & 12.9 & 14.6 & 24.6 & 4.4 & 14.8 & 3.1 & 3.7 & 14.9 \\
\hline SCRAP -7 & 6.6 & 6.5 & 14.1 & 14.4 & 23.4 & 3.6 & 11.0 & 2.3 & 3.4 & 14.6 \\
\hline SCRAP-8 & 2.7 & 11.0 & 37.9 & 15.8 & 13.6 & 2.0 & 6.5 & 1.3 & 1.6 & 7.6 \\
\hline SCRAP-9 & 1.8 & 3.4 & 15.0 & 14.9 & 21.7 & 4.0 & 14.1 & 2.9 & 4.2 & $17 . \dot{7}$ \\
\hline Mean & 3.4 & 6.3 & 21.4 & 15.4 & 20.7 & 3.4 & 10.9 & 2.2 & 3.0 & 13.1 \\
\hline \multirow[t]{2}{*}{ Range } & 4.8 & 7.6 & 25.0 & 3.3 & 11.0 & 2.4 & 8.3 & 1.8 & 2.6 & 10.1 \\
\hline & \multicolumn{10}{|c|}{ Cumulative Wt \% Less Than } \\
\hline Test No. & $+4750 \mu \mathrm{m}$ & $-4750 \mu \mathrm{m}$ & $-4000 \mu \mathrm{m}$ & $-2800 \mu \mathrm{m}$ & $-2000 \mu \mathrm{m}$ & $-1000 \mu \mathrm{m}$ & $-850 \mu \mathrm{m}$ & $-425 \mu \mathrm{m}$ & $-355 \mu \mathrm{m}$ & $-250 \mu \mathrm{m}$ \\
\hline SCRAP-4 & 100.0 & 96.5 & 89.0 & 62.6 & 44.9 & 23.4 & 20.6 & 12.0 & 10.5 & 8.5 \\
\hline SCRAP -5 & 100.0 & 97.2 & 91.5 & 69.2 & 54.2 & 34.7 & 31.3 & 20.7 & 18.6 & 15.3 \\
\hline SCRAP-6 & 100.0 & 97.1 & 93.0 & 80.1 & 65.5 & 40.9 & 36.5 & 21.7 & 18.6 & 14.9 \\
\hline SCRAP-7 & 100.0 & 93.4 & 86.8 & 72.1 & 58.3 & 34.9 & 31.3 & 20.3 & 18.0 & 14.6 \\
\hline SCRAP-8 & 100.0 & 97.3 & 86.3 & 48.4 & 32.6 & 19.0 & 17.0 & 10.5 & 9.2 & 7.6 \\
\hline SCRAP-9 & 100.0 & 98.2 & 94.8 & 79.8 & 64.9 & 43.2 & 39.2 & 24.8 & 21.9 & 17.7 \\
\hline Mean & 100.0 & 96.6 & 90.2 & 68.7 & 53.4 & 32.7 & 29.3 & 18.3 & 16.1 & 13.1 \\
\hline Range & 0 & 4.8 & 8.5 & 31.7 & 32.9 & 24.2 & 22.2 & 14.3 & 12.7 & 10.1 \\
\hline
\end{tabular}




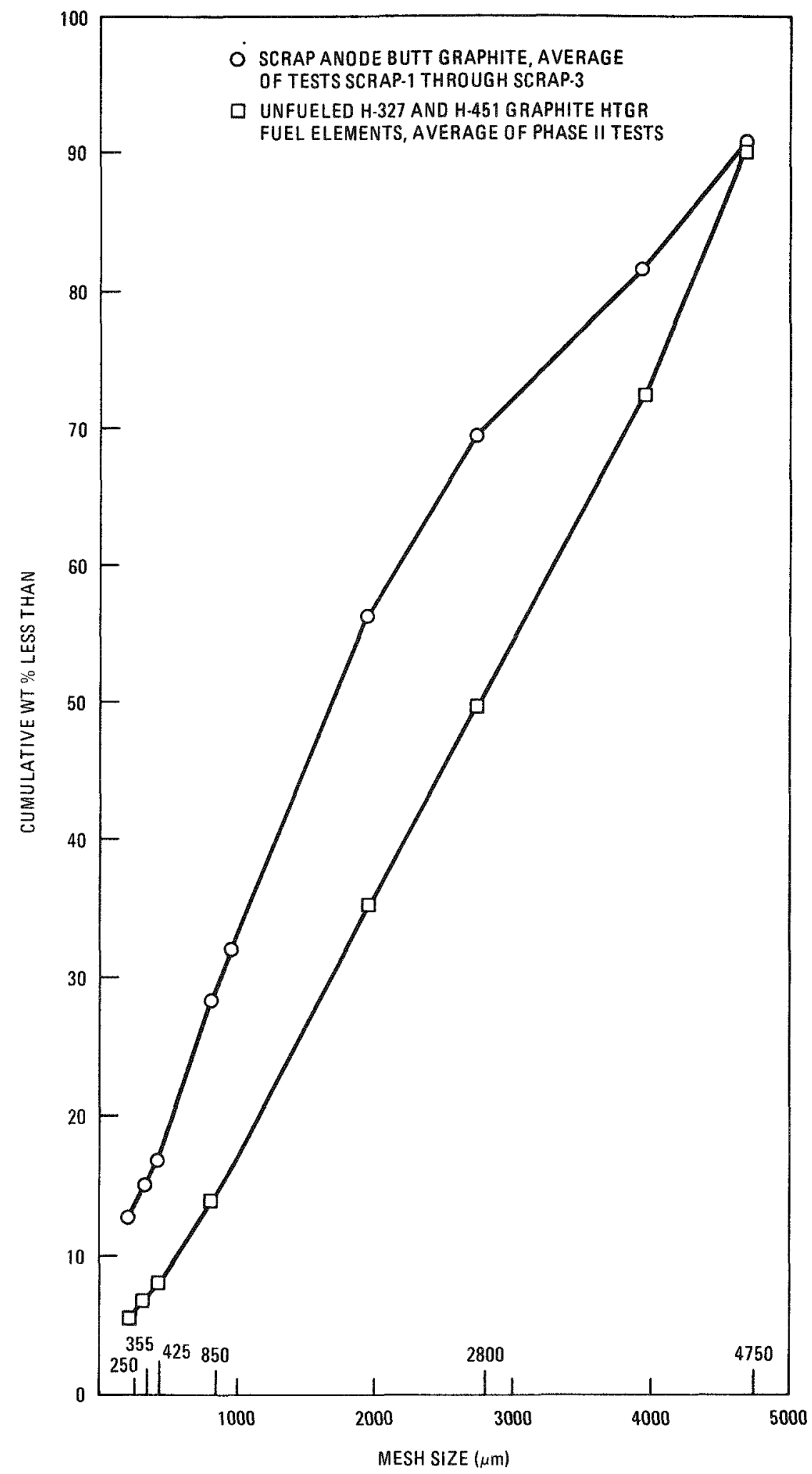

Fig. 5-5. Composite product comparison: fuel elements and scrap
graphite 
combined screener and oversize crusher products from the anode graphite crushing tests with the size distribution of composited screener and oversize crusher products from the HTGR graphite elements of the phase II tests. Figure 5-5 indicates that the crushed anode graphite was generally much finer. This is probably mainly attributable to the crushing characteristics of the solid materials and secondarily to the differences in graphite and attrition due to transport of the screener product.

At the conclusion of the first nine crushing tests with anode graphite, the UNIFRAME was partially dismantled and inspected to determine material holdup areas and to complete the material balance (Table 5-5). The material recovered was $99.10 \%$ of the charge, and the MUF was $0.90 \%$ of the charge. An additional $0.22 \%$ was recovered during clean-out of the system, resulting in a net MUF of $0.68 \%$. This increase from the $0.19 \%$ MUF obtained in the phase II tests was probably due to holdup in the UNIFRAME product bunker filters and increased material handling.

The number of blinded holes on the screener increased from 103, or $0.9 \%$, at the end of the phase II tests to 193 , or $1.7 \%$ (Table $5-5$ ). Although some of the increase in blinding may be attributable to the difference between scrap anode butt graphite and HTGR fuel element graphite, this result indicates that blinding will probably increase to a point where maintenance actions will be required to clear the screener.

Testing continued (SCRAP-10 through SCRAP-18) with studies of the effects of varying the oversize crusher operating parameters on pneumatic material transport of UNIFRAME products. In these tests the oversize crusher was placed so that its material discharged into the transport line downstream of the screener product discharge (the opposite of previous tests). The crushed product from the oversize crusher was easily transported in the initial two tests (SCRAP-10 and SCRAP-11), but crushed product from the screener was not transported (Fig. 5-6). This was opposite from the previous observation $(\operatorname{SCRAP}-4)$ and was attributed to insufficient 
TABLE 5-5

MATERIAL BALANCE, UNIFRAME SCRAP ANODE BUTT GRAPHITE CRUSHING, TESTS SCRAP-1 THROUGH SCRAP-9(a)

\begin{tabular}{c|c|c|c|c}
\hline $\begin{array}{c}\text { Test } \\
\text { No. }\end{array}$ & $\begin{array}{c}\text { Charge } \\
(\mathrm{kg})\end{array}$ & $\begin{array}{c}\text { Recovery } \\
(\mathrm{kg})\end{array}$ & $\begin{array}{c}\text { Gain (+) or } \\
\text { Loss (-) }\end{array}$ & $\begin{array}{c}\text { MUF } \\
(\% \text { of } \\
\text { Charge })\end{array}$ \\
\hline SCRAP-1 & 45.000 & 44.024 & $(-) 0.976$ & 2.17 \\
SCRAP-2 & 45.500 & 44.023 & $(-) 1.477$ & 3.25 \\
SCRAP-3 & 44.750 & 44.478 & $(-) 0.272$ & 0.61 \\
SCRAP-4 & 89.900 & 87.200 & $(-) 2.700$ & 3.00 \\
SCRAP-5 & 93.100 & 91.800 & $(-) 1.300$ & 1.40 \\
SCRAP-6 & 97.350 & 96.750 & $(-) 0.600$ & 0.62 \\
SCRAP-7 & 95.000 & 94.250 & $(-) 0.750$ & 0.79 \\
SCRAP-8 & 93.150 & 95.910 & $(+) 2.760$ & 2.96 \\
SCRAP-9 & 96.400 & 95.400 & $(-) 1.000$ & 1.04 \\
TotaI & 700.150 & 693.835 & $(-) 6.315$ & 0.90 \\
\hline
\end{tabular}

Cleanout at Conclusion of Testing

\begin{tabular}{l|c|c}
\hline \multicolumn{1}{c|}{ Description } & $\begin{array}{c}\text { Quantity } \\
(\mathrm{kg})\end{array}$ & $\begin{array}{c}\% \text { of } \\
\text { Charge }\end{array}$ \\
\hline Holdup on screener table & 0.757 & 0.11 \\
Dust in screener housing & 0.527 & 0.08 \\
Dust in oversize crusher housing & $\underline{0.210}$ & $\underline{0.03}$ \\
Total & 1.494 & 0.22 \\
\hline
\end{tabular}

Grand Totals

\begin{tabular}{c|c|c|c|c}
\hline Tests & $\begin{array}{c}\text { Charge } \\
(\mathrm{kg})\end{array}$ & $\begin{array}{c}\text { Recovery } \\
(\mathrm{kg})\end{array}$ & $\begin{array}{c}\text { Gain (+) or } \\
\text { Loss }(-)\end{array}$ & $\begin{array}{c}\text { MUF } \\
(\% \text { of } \\
\text { Charge) }\end{array}$ \\
\hline $\begin{array}{c}\text { SCRAP-1 through } \\
\text { SCRAP-9 }\end{array}$ & 700.150 & 695.329 & $(-) 4.821$ & 0.68 \\
\hline
\end{tabular}

${ }^{(a)}$ Screener blinded holes $=193=1.7 \%$. 


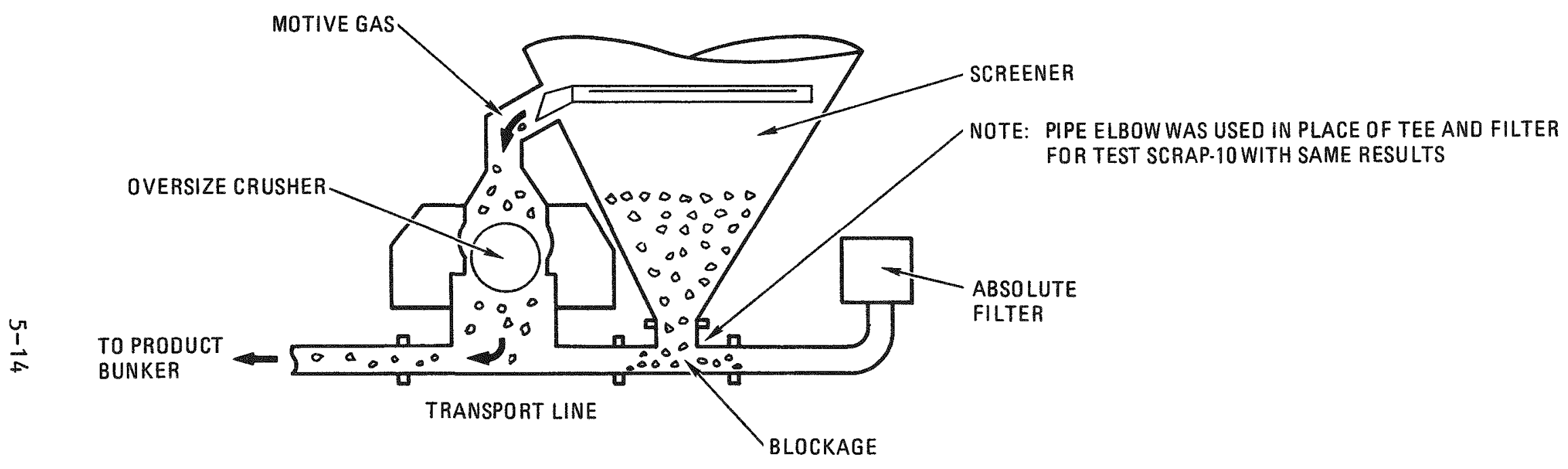

Fig. 5-6. Product transport arrangement: tests SCRAP-10 through SCRAP-18 (showing product transport line blockage of tests SCRAP-10 and SCRAP-11) 
motive gas flow through the screener because of an increased pressure drop at the screener product transport line entry point which diverted the motive gas through the new path of least resistance (i.e., the oversize crusher), allowing the screener product to salt out and completely block the screener discharge. The screener product was successfully transported at the end of each of these test by rodding out the line blockage. It became obvious from these tests and SCRAP -4 that crushed materials discharged from the equipment item closest to the product bunker would inevitably be preferentially transported, with subsequent blockage of the other discharge. It was also determined that this effect could not be overcome by differences in pressure drops across the equipment alone, and some additional means of increasing the pressure drop would have to be utilized.

For the next test (SCRAP-12), the oversize crusher was not operated until after secondary crushing was complete (screening was also essentially complete). This allowed the pressure drop to increase across the oversize crusher owing to material backing up in the feed chute, forcing the motive gas through the screener and affecting transport. The oversize crusher was started (under full load), and its product was discharged and transported. Inspection of the system revealed complete material transport and no abnormal material holdup.

During the next several tests (SCRAP 13 through SCRAP-18), the oversize crusher was intermittently operated throughout the crushing operation to allow periodic fluctuations in pressure drop. These parameters and results are summarized in Table 5-6. Crushed product was completely transported from the screener and the oversize crusher in every run. However, blockages occurred during the transport of screener product in some tests, but in each case, transport was restarted during the next shutdown cycle of the oversize crusher.

The product size distributions obtained in these tests are given in Table 5-7. Figure 5-7 compares the size distribution of crushed anode 
TABLE 5-6

UNIFRAME PRODUCT PNEUMATIC TRANSPORT WITH INTERMITTENT OVERSIZE CRUSHER OPERATION

\begin{tabular}{|c|c|c|c|c|}
\hline \multirow[b]{2}{*}{ Run No. } & \multicolumn{2}{|c|}{$\begin{array}{l}\text { Oversize Crusher } \\
\text { Operating Time } \\
\text { From Start of Crushing } \\
\end{array}$} & \multirow[b]{2}{*}{ Duration } & \multirow[b]{2}{*}{ Remarks } \\
\hline & On & off & & \\
\hline \multirow[t]{3}{*}{ SCRAP-13 } & $3 \min 30 \mathrm{~s}$ & $4 \min 0 \mathrm{~s}$ & $30 \mathrm{~s}$ & No effect on screener product transport. \\
\hline & $5 \min 0 \mathrm{~s}$ & $5 \min 30 \mathrm{~s}$ & $30 \mathrm{~s}$ & \\
\hline & $5 \min 45 \mathrm{~s}$ & End of test & $\sim 9 \min 15 \mathrm{~s}$ & \\
\hline \multirow[t]{3}{*}{$\operatorname{SCKAP}-14$} & $1 \min 0 \mathrm{~s}$ & $2 \min 0 \mathrm{~s}$ & $1 \min$ & $\begin{array}{l}\text { Screener product transport stopped. } \\
\text { Restarted with crusher off. }\end{array}$ \\
\hline & $3 \mathrm{~min} 0 \mathrm{~s}$ & $4 \min 0 \mathrm{~s}$ & $1 \min$ & No effect on screener product transport. \\
\hline & $5 \min 0 \mathrm{~s}$ & End of test & $\sim 10 \mathrm{~min}$ & \\
\hline \multirow[t]{3}{*}{ SCRAP -15} & $2 \min 0 s$ & $4 \min 0 \mathrm{~s}$ & $2 \min$ & $\begin{array}{l}\text { Screener product transport stopped. } \\
\text { Restarted with crusher off. }\end{array}$ \\
\hline & $4 \min 30 \mathrm{~s}$ & $5 \min 30 \mathrm{~s}$ & $1 \min$ & $\begin{array}{l}\text { Screener product transport stopped. } \\
\text { Restarted with crusher off. }\end{array}$ \\
\hline & $6 \min 24 \mathrm{~s}$ & End of test & $\sim 8 \min 36 \mathrm{~s}$ & No effect on screener product transport. \\
\hline SCRAP-16 & $1 \mathrm{~min} 30 \mathrm{~s}$ & $1 \min 45 \mathrm{~s}$ & $15 \mathrm{~s}$ & No effect on screener product transport. \\
\hline & $2 \min 30 \mathrm{~s}$ & $2 \min 45 s$ & $15 \mathrm{~s}$ & \\
\hline & $3 \mathrm{~min} 30 \mathrm{~s}$ & $3 \min 45 \mathrm{~s}$ & $15 \mathrm{~s}$ & \\
\hline & $4 \min 30 \mathrm{~s}$ & $4 \min 45 \mathrm{~s}$ & $15 \mathrm{~s}$ & \\
\hline & $5 \min 30 \mathrm{~s}$ & End of test & $\sim 9 \min 30 \mathrm{~s}$ & \\
\hline SCRAP -17 & & & & Same as SCRAP-16. \\
\hline SCRAP-18 & & & & Same as SCRAP-16. \\
\hline
\end{tabular}


TABLE 5-7

PRODUCT SIZE DISTRIBUTIONS: ANODE BUTT SCRAP GRAPHITE SCREENER AND OVERSIZE CRUSHER PRODUCT TRANSPORT

\begin{tabular}{|c|c|c|c|c|c|c|c|c|c|c|}
\hline \multirow[b]{2}{*}{ Test No. } & \multicolumn{10}{|c|}{ Wt $\%$ of Screened Fractions } \\
\hline & $+4750 \mu \mathrm{m}$ & $\begin{array}{l}-4750 \\
+4000 \mu \mathrm{m}\end{array}$ & $\begin{array}{l}-4000 \\
+2800 \mu \mathrm{m}\end{array}$ & $\begin{array}{l}-2800 \\
+2000 \mu \mathrm{m}\end{array}$ & $\begin{array}{l}-2000 \\
+1000 \mu \mathrm{m}\end{array}$ & $\begin{array}{l}-1000 \\
+850 \mu \mathrm{m}\end{array}$ & $\begin{array}{l}-850 \\
+425 \mu \mathrm{m}\end{array}$ & $\begin{array}{l}-425 \\
+355 \mu \mathrm{m}\end{array}$ & $\begin{array}{l}-355 \\
+250 \mu \mathrm{m}\end{array}$ & $-250 \mu \mathrm{m}$ \\
\hline SCRAP- 10 & 0.1 & 2.6 & 23.2 & 15.0 & 16.9 & 3.5 & 13.9 & 2.9 & 4.0 & 17.8 \\
\hline SCRAP-11 & 0.1 & 1.9 & 16.8 & 13.4 & 18.3 & 4.0 & 16.4 & 3.5 & 4.7 & 20.9 \\
\hline SCRAP- 12 & 4.2 & 9.9 & 25.5 & 16.2 & 18.0 & 2.7 & 10.3 & 1.9 & 2.4 & 8.9 \\
\hline SCRAP-13 & 2.2 & 6.3 & 26.3 & 16.9 & 19.3 & 3.1 & 10.6 & 2.0 & 2.4 & 10.9 \\
\hline SCRAP-14 & 1.2 & 4.2 & 21.0 & 15.6 & 18.2 & 3.4 & 12.7 & 3.0 & 4.2 & 16.5 \\
\hline SCRAP- 15 & 1.3 & 5.5 & 23.4 & 15.4 & 17.8 & 3.6 & 13.6 & 2.5 & 3.4 & 13.5 \\
\hline SCRAP- 16 & 0.9 & 3.0 & 17.9 & 12.8 & 16.1 & 3.6 & 15.3 & 3.6 & 5.2 & 21.6 \\
\hline SCRAP-17 & 1.0 & 3.3 & 16.3 & 11.7 & 16.1 & 3.7 & 15.6 & 3.4 & 5.3 & 23.6 \\
\hline SCRAP- 18 & 3.6 & 5.2 & 17.9 & 12.9 & 14.9 & 3.0 & 12.3 & 2.9 & 4.6 & 22.7 \\
\hline Mean & 1.6 & 4.7 & 20.9 & 14.4 & 17.3 & 3.4 & 13.4 & 2.9 & 4.0 & 17.4 \\
\hline Range & 4.1 & 8.0 & 10.0 & 5.2 & 4.4 & 1.3 & 6.1 & 1.7 & 2.9 & 14.7 \\
\hline
\end{tabular}

\begin{tabular}{l|c|c|c|c|c|c|c|c|c|c|c}
\hline & \multicolumn{10}{c}{ Cumulative Wt \% Less Than } \\
\cline { 2 - 10 } & $+4750 \mu \mathrm{m}$ & $-4750 \mu \mathrm{m}$ & $-4000 \mu \mathrm{m}$ & $-2800 \mu \mathrm{m}$ & $-2000 \mu \mathrm{m}$ & $-1000 \mu \mathrm{m}$ & $-850 \mu \mathrm{m}$ & $-425 \mu \mathrm{m}$ & $-355 \mu \mathrm{m}$ & $-250 \mu \mathrm{m}$ \\
\hline SCRAP-10 & 100.0 & 99.9 & 97.3 & 74.0 & 59.0 & 42.1 & 38.6 & 24.7 & 21.8 & 17.8 \\
SCRAP-11 & 100.0 & 99.9 & 98.0 & 81.2 & 67.8 & 49.5 & 45.5 & 29.1 & 25.6 & 20.9 \\
SCRAP-12 & 100.0 & 95.8 & 85.9 & 60.4 & 44.2 & 26.2 & 23.5 & 13.2 & 11.3 & 8.9 \\
SCRAP-13 & 100.0 & 97.8 & 91.5 & 65.2 & 48.3 & 29.0 & 25.9 & 15.3 & 13.3 & 10.9 \\
SCRAP-14 & 100.0 & 98.8 & 94.6 & 73.6 & 58.0 & 39.8 & 36.4 & 23.7 & 20.7 & 16.5 \\
SCRAP-15 & 100.0 & 98.7 & 93.2 & 69.8 & 54.4 & 36.6 & 33.0 & 19.4 & 16.9 & 13.5 \\
SCRAP-16 & 100.0 & 99.1 & 96.1 & 78.2 & 65.4 & 49.3 & 45.7 & 30.4 & 26.8 & 21.6 \\
SCRAP-17 & 100.0 & 99.0 & 95.7 & 79.4 & 67.7 & 51.6 & 47.9 & 32.3 & 28.9 & 23.6 \\
SCRAP-18 & 100.0 & 96.4 & 91.2 & 73.3 & 60.4 & 45.5 & 42.5 & 30.2 & 27.3 & 22.7 \\
Mean & 100.0 & 98.4 & 93.7 & 72.8 & 58.4 & 41.1 & 37.7 & 24.3 & 21.4 & 17.4 \\
Range & 0 & 4.1 & 12.1 & 20.8 & 23.6 & 25.4 & 24.4 & 19.1 & 17.6 & 14.7
\end{tabular}




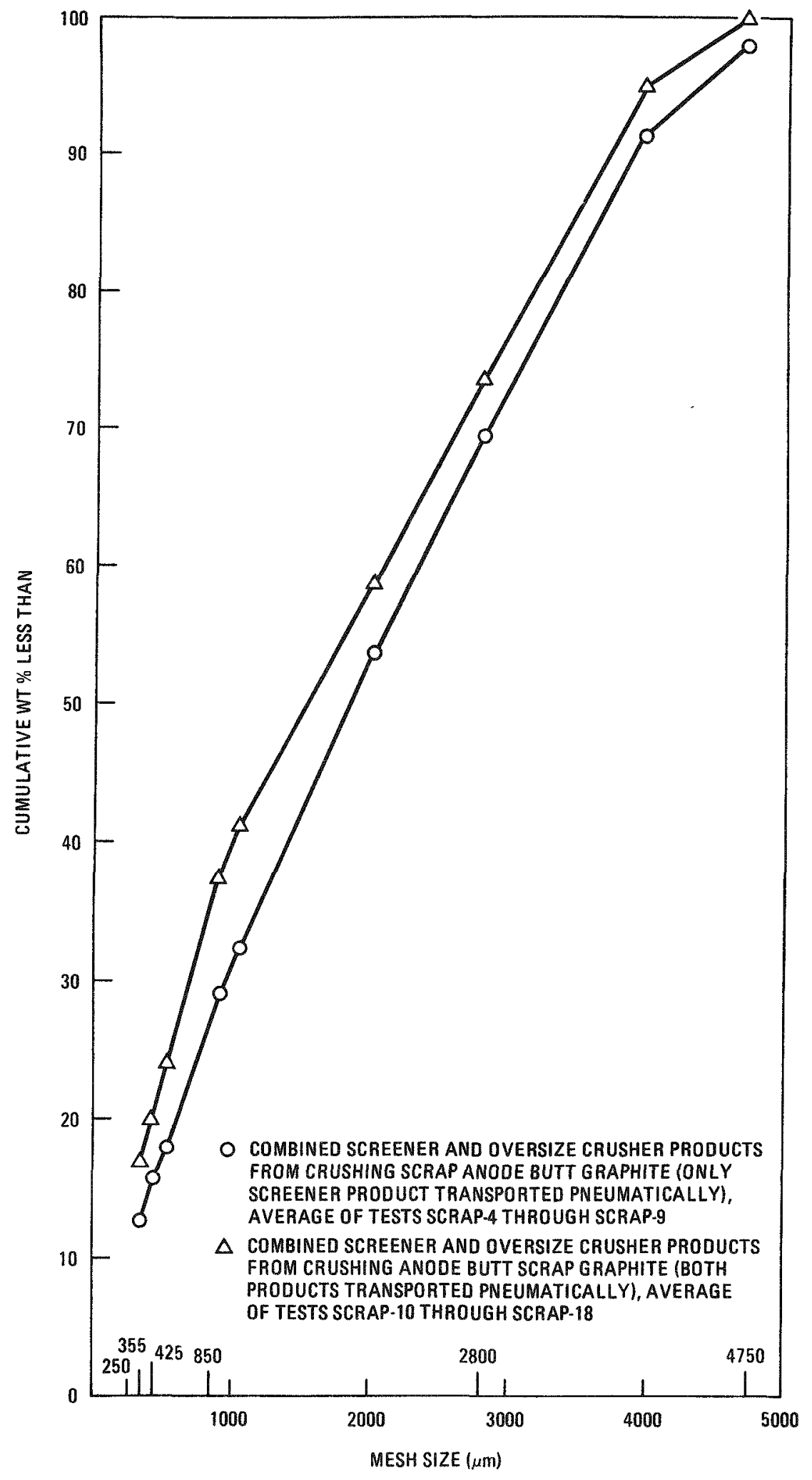

Fig. 5-7. Effect of transport on combined screener and oversize crusher products 
graphite from tests in which only screener product was transported (SCRAP-4 through SCRAP-9) with tests in which both screener and oversize crusher products were transported through the pneumatic transport system (SCRAP-10 through SCRAP-18). Figure 5-7 shows that the completely transported product was finer, which is attributable to attrition due to transport. However, the transport system was not operated at the optimum parameters (i.e., lowest transport velocity to reduce particle breakage), and thus under optimum transport conditions this effect would be reduced.

At the conclusion of the second series of nine crushing tests (SCRAP10 through SCRAP-18) with anode graphite, the UNIFRAME was again partially dismantled and inspected to determine material holdup areas and to complete the material balance. At the end of this series, the material recovered was $99.07 \%$ of the charge, and the MUF was $0.93 \%$ of the charge (Table $5-8$ ). These results were very close to the results of the first series (i.e., $99.10 \%$ recovery and $0.90 \%$ MUF) (Table $5-5$ ). An additional $0.59 \%$ was recovered during clean-out of the system, resulting in a net MUF of $0.34 \%$. The number of blinded holes increased from 193 , or $1.7 \%$, at the end of SCRAP -9 to 423 , or $3.7 \%$, at the end of SCRAP-18, reaffirming the need for clearing the screener.

In the next three tests (SCRAP-19 through SCRAP-21), the oversize crusher and the inner vibrating section of the screener were removed from the UNIFRAIE system so that the operation of the pneumatic transport system with material which had not been screened and oversize material which had not been crushed (Fig. 5-8) could be observed. This provided information on the capability of the transport system to handle the largest particle produced through the tertiary crushing stage and to transport it without the benefit of a quasi-metered feed provided by the screener at its maximum throughput.

In the first test of this series (SCRAP-19), the screener discharge stopped after approximately $1 \mathrm{~min}$ of crushing, and no further transport 
TABLE 5-8

MATERIAL BALANCE, UNIFRAME SCRAP ANODE BUTT GRAPHITE CRUSHING, TESTS SCRAP-10 THROUGH SCRAP-18(a)

\begin{tabular}{c|c|c|c|c}
\hline $\begin{array}{c}\text { Test } \\
\text { No. }\end{array}$ & $\begin{array}{c}\text { Charge } \\
(\mathrm{kg})\end{array}$ & $\begin{array}{c}\text { Recovery } \\
(\mathrm{kg})\end{array}$ & $\begin{array}{c}\text { Gain (+) or } \\
\text { Loss (-) }\end{array}$ & $\begin{array}{c}\text { MUF } \\
\text { (\% of } \\
\text { Charge) }\end{array}$ \\
\hline SCRAP-10 & 96.125 & 94.000 & $(-) 2.125$ & 2.21 \\
SCRAP-11 & 97.200 & 97.800 & $(+) 0.600$ & 0.62 \\
SCRAP-12 & 101.153 & 100.903 & $(-) 0.250$ & 0.25 \\
SCRAP-13 & 96.616 & 96.643 & $(+) 0.027$ & 0.03 \\
SCRAP-14 & 96.620 & 95.919 & $(-) 0.701$ & 0.73 \\
SCRAP-15 & 96.620 & 96.164 & $(-) 0.456$ & 0.47 \\
SCRAP-16 & 99.792 & 98.119 & $(-) 1.673$ & 1.68 \\
SCRAP-17 & 98.431 & 97.172 & $(-) 1.259$ & 1.28 \\
SCRAP-18 & 81.194 & 78.988 & $(-) 2.206$ & 2.72 \\
Tota1 & 863.751 & 855.708 & $(-) 8.043$ & 0.93 \\
\hline
\end{tabular}

Cleanout at Conclusion of Testing

\begin{tabular}{l|c|c}
\hline Description & $\begin{array}{c}\text { Quantity } \\
(\mathrm{kg})\end{array}$ & $\begin{array}{c}\% \text { of } \\
\text { Charge }\end{array}$ \\
\hline Holdup on screener table & 3.575 & 0.41 \\
Dust in screener housing & 0.261 & 0.03 \\
Dust in oversize crusher housing & $\underline{1.260}$ & $\underline{0.15}$ \\
Total & 5.096 & 0.59 \\
\hline
\end{tabular}

Grand Totals

\begin{tabular}{c|c|c|c|c}
\hline Tests & $\begin{array}{c}\text { Charge } \\
(\mathrm{kg})\end{array}$ & $\begin{array}{c}\text { Recovery } \\
(\mathrm{kg})\end{array}$ & $\begin{array}{c}\text { Gain (t) or } \\
\text { Loss }(-)\end{array}$ & $\begin{array}{c}\text { MUF } \\
(\% \text { of } \\
\text { Charge })\end{array}$ \\
\hline $\begin{array}{l}\text { SCRAP-10 through } \\
\text { SCRAP-18 }\end{array}$ & 863.751 & 860.804 & $(-) 2.947$ & 0.34 \\
\hline
\end{tabular}

${ }^{(a)}$ Screener blinded holes $=423=3.7 \%$. 


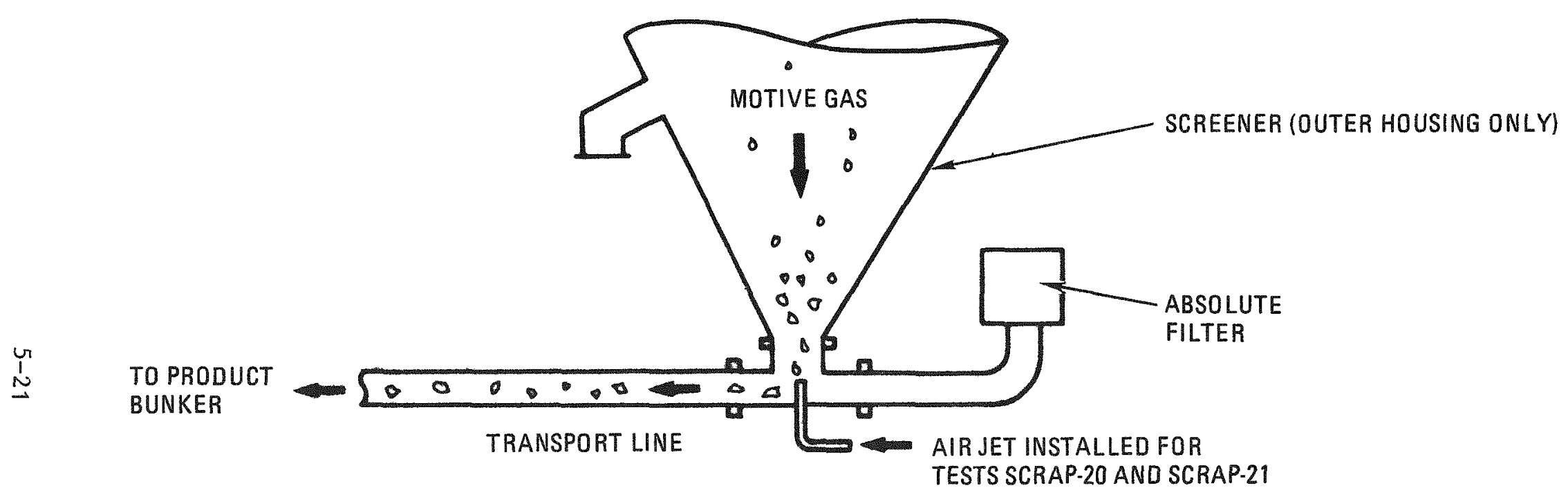

Fig. 5-8. Product transport arrangement: tests SCRAP-19 through SCRAP-21 and crushing of HTGR fue1 element I-2319 
occurred. After crushing was completed, the transport line was inspected and found to be clear. The blockage had apparently occurred at the apex of the screener outer housing. A wire was used to dislodge the obstruction, and transport resumed to completion. Examination of the product revealed several fairly large wafer-like fragments which had been transported. One fragment which had passed through the $5-\mathrm{cm} 0 . d \cdot / 4.8-\mathrm{cm}$ i.d. transport tubing measured $6.4 \times 3.2 \times 0.24 \mathrm{~cm}$. It was this or similar fragments which were suspected of producing the blockage in the screener discharge.

Prior to the second test of this series (SCRAP-20), an air jet was installed in the transport line tee at the screener discharge. During crushing, the air jet provided short blasts of $4.88-\mathrm{kg} / \mathrm{m}^{2}$ air in the area where the previous blockage had occurred. The jet was used when there was a slowdown in the flow of material to the transport line and was only necessary until approximately the midpoint of the test; after that, the peak load at the discharge area was past and the jet was not required to maintain material flow.

During SCRAP-20, the UNIFRAME emergency stop button was inadvertent1y pressed, and the three crushers stopped. Primary crushing had been completed, and so start-under-load was not required. The secondary crusher restarted without difficulty under this loaded condition. The tertiary crusher also started without difficulty, with a single roll and both rolls operating. During SCRAP-21, the air jet was utilized only three times in short bursts during the peak loading periods of the crushing operation. The air jet was used when transport flow had slowed down, although it may not have been necessary to use the jet to continue the flow.

A final test was conducted without the screener and oversize crusher using a full-Iength $\mathrm{H}-327$ graphite unloaded HTGR fuel element: transport was completed without the use of the air jet. As previously indicated, the wafer-like nature of some of the product obtained from crushing anode graphite seemed to be the major contributor to the blockage at the apex of the screener outer housing. 
A slot valve was designed, constructed, and installed for future tests. This valve provides a restriction in the oversize crusher discharge to the transport line, allows the pressure drops to be controlled, and prevents preferential transport of material from the oversize crusher (Fig. 5-9).

5.4. SLOT VALVE TESTS

Four separate tests (SCRAP-22 through SCRAP-25) we re completed utilizing anode butt scrap graphite to test the feasibility of the slot valve and to provide additional feed for primary burner tests. In the initial test (SCRAP-22), the slot valve was set at its $50 \%$ open position, and the screener failed to discharge during the crushing operation. After crushing was completed and with the screener housing containing its entire inventory of product, the slot valve was completely closed. Discharge of the screener product commenced immediately and automatically without assistance and continued without interruption until the entire product had been pneumatically transported.

For the second test (SCRAP-23), the slot valve was reset at its $25 \%$ open position. Material discharge and pneumatic transport from the screener and the oversize crusher were complete and problem-free. Two more tests were made with the slot valve at its $25 \%$ open position (SCRAP-24 and SCRAP-25), and both tests resulted in trouble-free transport.

At the conclusion of this series of four tests, the system was cleaned out to obtain a complete material balance. Material balance results for these tests and summaries of the material balances for the previous tests are given in Table 5-9. The MUF in each of the current tests as well as the total MUF for the entire four-run series was, in general, greater than that in the previous 21 tests. The reason for the increased MUF is not known for certain, but it is probably due to the premature shutdown of the secondary and tertiary crushers. It has been the practice to shut 


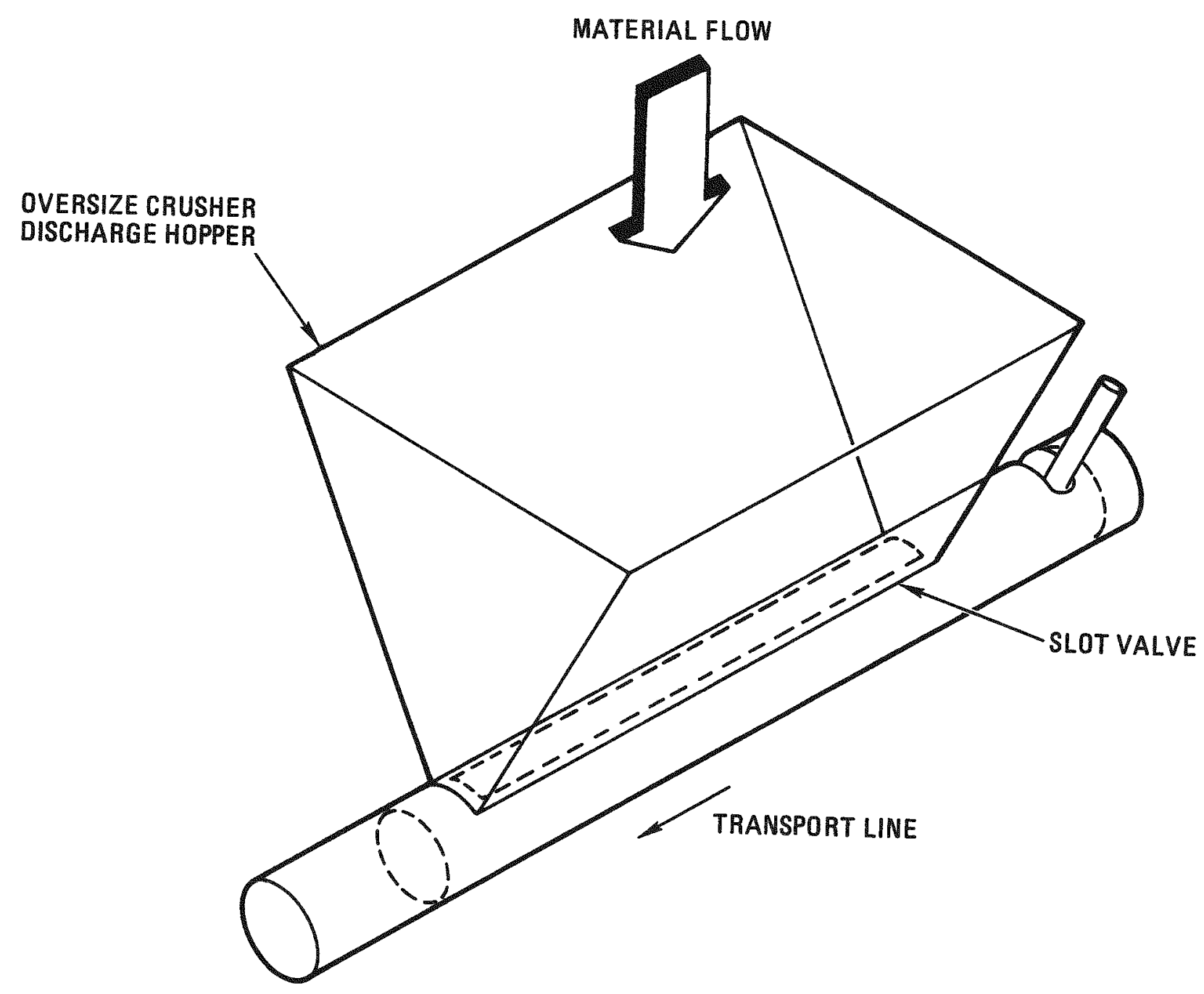

Fig. 5-9. Oversize crusher slot valve 
TABLE 5-9

MATERIAL BALANCE RESULTS FROM SCRAP GRAPHITE CRUSHING

\begin{tabular}{|c|c|c|c|c|}
\hline $\begin{array}{l}\text { Test } \\
\text { No. }\end{array}$ & $\begin{array}{l}\text { Charge } \\
(\mathrm{kg})\end{array}$ & $\begin{array}{l}\text { Recovery } \\
(\mathrm{kg})\end{array}$ & $\begin{array}{l}\text { Gain }(+) \\
\text { or Loss }(-)\end{array}$ & $\begin{array}{c}\text { MUF } \\
(\% \text { of } \\
\text { Charge) }\end{array}$ \\
\hline \multicolumn{5}{|c|}{ Prior Tests } \\
\hline SCRAP -1 to -9 & 700.150 & 695.329 & $(-) 4.821$ & 0.68 \\
\hline SCRAP -10 to -18 & 863.751 & 860.804 & $(-) 2.947$ & 0.34 \\
\hline $\begin{array}{l}\text { SCRAP-19 to }-21 \text { and } \\
\text { element } 1-2319\end{array}$ & 388.054 & $\underline{384.363}$ & $(-) \quad 3.691$ & 0.95 \\
\hline Total & 1951.955 & 1940.496 & $(-) 11.459$ & 0.59 \\
\hline \multicolumn{5}{|c|}{ Current Tests } \\
\hline SCRAP-22 & 97.395 & 92.908 & (-) 4.487 & 4.61 \\
\hline SCRAP-23 & 96.942 & 95.583 & (-) 1.359 & 1.40 \\
\hline SCRAP-24 & 97.395 & 94.677 & $(-) 2.718$ & 2.79 \\
\hline SCRAP -25 & 97.395 & $113.740^{(a)}$ & $(+) 16.345$ & $16.78^{(a)}$ \\
\hline Tota1 & 389.127 & 396.908 & (+) 7.781 & 2.00 \\
\hline \multicolumn{5}{|c|}{ Total for All Tests } \\
\hline SCRAP -1 to -25 & 2341.082 & 2337.404 & $(-) 3.678$ & 0.12 \\
\hline
\end{tabular}

(a) Includes material recovered from system cleanout at end of tests. 
down each major equipment item after it has completed its stage of the crushing operation. With the ventilation shrouding completely in place (installation was completed prior to SCRAP-19), visual observation of completion of secondary crushing is 1imited, and the secondary and tertiary crushers may have been shut down prior to complete material discharge. To achieve complete clean-out after the conclusion of SCRAP-25, the equipment. was restarted and operated for several minutes. As can be seen from Table $5-9$, this resulted in the recovery of several kilograms of material and an excellent overal1 MUF of $0.12 \%$ of the total charge during all 25 anode butt scrap graphite crushing tests. In the remaining tests, all equipment items will be operated past their normal completion times up to a 15-min maximum to ensure a more complete clean-out. 
6. PHASE III: UNIFRAME SYSTEM TESTS WITH FUELED ELEMENTS

\subsection{INTRODUCTION}

The major objectives of the phase III tests were to determine the extent of fuel particle breakage when Fort St. Vrain (FSV) and large HTGR (LHTGR) fuel and control rod elements were crushed and to demonstrate the degree to which the design criterion had been met.

\subsection{FUEL MATERIALS}

The following types of fueled HTGR elements were used as feed for the phase III tests:

1. Three FSV H-327 gxaphite standard fuel elements fueled with TRISO/TRISO particles (tests UL-58, UL-59, UL-60).

2. One FSV H-327 graphite control rod element fueled with TRISO/TRISO particles (test UL-61).

3. Three LHTGR H-451 graphite standard fuel elements fueled with TRISO/BISO particles (tests UL-64, UL-65, UL-66).

\subsection{OPERATING PROCEDURES}

In each of the phase III teats, the crushed products from the oversize crusher and the screener were separately collected for analysis of their particle breakage and product size distributions. To determine the relative quantities of product discharging from each and to avoid potential additional particle breakage from pneumatic transport of the product, the 
crushed products from the screener were collected in a plastic bag attached to the discharge flange at the apex of the cone on the outer housing. The crushed products from the oversize crusher were collected in a vacuum cleaner connected to the discharge line of the crusher and equipped with an absolute filter to prevent the release of radioactive materials.

To obtain maximum recovery of the crushed materials from each test for the material balance, the secondary crusher was operated for several minutes after complete discharge up to a maximum of $15 \mathrm{~min}$ owing to limited visibility; the screener, oversize crusher, and tertiary crusher were operated for 15 min after initial charging of the fuel element because of the inability for direct observation of the conclusion of operations. In addition, a port was removed from the screener after normal shutdown, and residual material on the screen surface was brushed into the discharge and then to the oversize crusher. The screener and oversize crusher were then operated for an additional 3 to $5 \mathrm{~min}$ to complete clean-out and crushing.

Normal ventilation supplied by the material transport blower through the transport lines was not possible because of the method of separate product collection, so the blower suction was attached to a port above the screen surface to provide an air flow and a negative pressure equivalent to those in standard operations. The dusts removed from the system were collected in the product bunker of the transport system.

\subsection{EQUIPMENT OPERATION AND TEST OBSERVATIONS}

No equipment operating problems were encountered during any of the phase III tests. However, two wafer-like fragments of scrap anode butt graphite which were apparently overlooked in the clean-out at the conclusion of scrap graphite crushing were lodged in the oversize discharge chute at the end of the initial test (UL-64). These fragments prevented material from entering the oversize crusher, causing the chute to fill with crushed material and the excess to overflow into the screener housing and 
discharge with the screener product. The material contained in the chute was subsequently crushed in the oversize crusher, but the initial upset condition rendered the data from this test invalid for use in comparing the quantity and size distribution of screener and oversize crusher products with other tests; it also biased the particle breakage data. Blockages did not recur in subsequent tests following removal of the scrap graphite fragments. To prevent this problem, the wafer-1ike scrap graphite will not be used as feed in the future.

In another test, a single fuel element fragment (estimated to be approximately $10 \times 3.8 \times 13 \mathrm{~cm}$ in size) remained in the secondary crushing cavity at the end of the normal 15-min maximum operating period. This fragment was moved from its original location in the cavity using a steel rod, and it was immediately crushed upon restarting of the secondary crusher. The fragment may have been crushed without mechanical assistance if there had been additional operating time or more material charged to the crusher. Methods for avoiding this situation will be investigated for incorporation in the design. Continuous air monitors, one at the fuel charging port and one at the product discharge, and wipes of the floor and machine surfaces detected no radiation above the normal background counts either during or after any of the phase III tests, indicating that complete containment was achieved in the ventilation enclosure.

\subsection{PROCESSING TIMES}

Owing to the Iimited visibility through the ventilation enclosure, the system process time and throughput rates could not be established with great accuracy. However, observations through the fuel charging port indicated that crushing was essentially complete in less than $5 \mathrm{~min}$, except in the single test, in which a fragment remained in the secondary crusher (see Section 6.4). Generally, the remainder of the 15-min operating time is necessary only to ensure a more complete discharge of residual materials on the screener surface and as a precaution because of the inability to observe the conclusion of each process stage directly. 


\subsection{MATERIAL BALANCES}

To obtain complete material balance information, each of the fuel elements used in the phase III tests was weighed fust prior to charging; the resulting crushed products were weighed at the conclusion of each test using the modified operating conditions described in section 6.3 for complete clean-out. The average quantity of MUF in each test was $0.24 \%$ of the original charge. The highest MUF in an individual test was $0.44 \%$, and the lowest was less than $0.01 \%$. The total MUF for all phase III tests was $0.13 \%$. Clean out of the dust in the vent system resulted in an additional recovery of $1.027 \mathrm{~kg}$ and a final overall MUF of $<0.001 \%$. Complete material balance data for all phase III tests are given in Table 6-1.

\subsection{RELATIVE QUANTITIES OF SCREENER AND OVERSIZE CRUSHER PRODUCT}

During phase I testing of the tertiary crusher and screener, it was revealed that oversize material remaining in the product through the tertiary crushing stage averaged on 1 y $1 \%$. However, even the use of crushed product which contained no oversize material at all resulted in up to $8 \%$ of that product discharging as oversize product owing to screener inefficiency. Therefore, it was expected that in the phase III tests the relative quantities of crushed material discharging from the screener and oversize crusher would be more of an indication of the screening efficiency than the actual quantity of oversize material produced during crushing.

Crushed materials discharged from the screener and oversize crusher were separately collected during the phase III tests as described in Section 6.3. The relative quantities of each are shown in Table 6-2. The percentage of crushed material discharged from the oversize crusher was largest (11.41\% mean) from crushing FSV H-327 graphite standard fuel elements, next largest (9.45\%) from the FSV H-327 graphite control rod element, and smallest ( $8.09 \%$ mean) from LHTGR H-451 graphite standard fuel elements. In general, these results indicate that greater screening efficiency was obtained with fueled elements than with unfueled elements (see Table 6-2). 
TABLE 6-1

MATERIAL BALANCE: PHASE III TESTS

\begin{tabular}{l|c|c|c|c}
\hline \multicolumn{1}{|c|}{ Test No. } & $\begin{array}{c}\text { Charge } \\
(\mathrm{kg})\end{array}$ & $\begin{array}{c}\text { Recovery } \\
(\mathrm{kg})\end{array}$ & $\begin{array}{c}\text { Gain (+) } \\
\text { or Loss }(-)\end{array}$ & $\begin{array}{c}\text { MUF } \\
\text { (\% of } \\
\text { Charge })\end{array}$ \\
\hline UL-58 & 129.090 & 128.724 & $(-) 0.366$ & 0.28 \\
UE-59 & 128.500 & 127.929 & $(-) 0.571$ & 0.44 \\
UL-60 & 128.181 & 128.058 & $(-) 0.123$ & 0.10 \\
UE-61 & 109.318 & 109.729 & $(+) 0.411$ & 0.38 \\
UL-64 & 122.243 & 122.241 & $(-) 0.003$ & $<0.01$ \\
UL-65 & 121.300 & 121.652 & $(+) 0.352$ & 0.29 \\
UL-66 & 122.763 & 122.523 & $(-) 0.240$ & 0.20 \\
Subtota1 & 861.935 & 860.856 & $(-) 1.079$ & 0.13 \\
$\begin{array}{l}\text { Dust in vent } \\
\text { system }\end{array}$ & -1.027 & $(+) 1.027$ & 0.12 \\
\hline \begin{tabular}{l} 
Grand Tota1 \\
\hline
\end{tabular} & 861.935 & 861.883 & $(-) 0.052$ & $<0.01$ \\
\hline
\end{tabular}


TABLE 6-2

PRODUCT DISTRIBUTION

A. Phase III Tests - Fueled HTGR Elements

\begin{tabular}{|c|c|c|c|c|}
\hline \multirow[b]{2}{*}{$\begin{array}{l}\text { Test } \\
\text { No. }\end{array}$} & \multicolumn{2}{|c|}{ Oversize Crusher Product } & \multicolumn{2}{|c|}{ Screener Product } \\
\hline & $\mathrm{kg}$ & $\begin{array}{l}\% \text { of Total } \\
\text { Product }\end{array}$ & $\mathrm{kg}$ & $\begin{array}{l}\% \text { of Total } \\
\text { Product }\end{array}$ \\
\hline \multicolumn{5}{|c|}{$\mathrm{H}-327 \mathrm{Gr}$} \\
\hline $\begin{array}{l}\text { UL-58 } \\
\text { UL-59 } \\
\text { UL-60 } \\
\text { Mean } \\
\text { Range }\end{array}$ & $\begin{array}{r}15.253 \\
15.166 \\
13.454 \\
14.624 \\
1.799\end{array}$ & $\begin{array}{r}11.85 \\
11.86 \\
10.51 \\
11.41 \\
1.35\end{array}$ & $\begin{array}{r}113.471 \\
112.763 \\
114.604 \\
113.613 \\
1.841 \\
\end{array}$ & $\begin{array}{r}88.15 \\
88.14 \\
89.49 \\
88.59 \\
1.35 \\
\end{array}$ \\
\hline \multicolumn{5}{|c|}{ H-327 Graphite - FSV Control Rod Element } \\
\hline $\mathrm{UL}-61$ & 10.372 & 9.45 & 99.357 & 90.55 \\
\hline \multicolumn{5}{|c|}{ H-451 Graphite - LHTGR Standard Fuel Elements } \\
\hline $\begin{array}{l}U L-64(\mathrm{a}) \\
\mathrm{UL}-65 \\
\mathrm{UL}-66 \\
\text { Mean } \\
\text { Range }\end{array}$ & $\begin{array}{r}0.915 \\
11.152 \\
8.591 \\
9.872 \\
2.633 \\
\end{array}$ & $\begin{array}{l}0.75 \\
9.17 \\
7.01 \\
8.09 \\
2.16 \\
\end{array}$ & $\begin{array}{r}121.326 \\
110.500 \\
113.932 \\
112.216 \\
3.432 \\
\end{array}$ & $\begin{array}{r}99.25 \\
90.83 \\
92.99 \\
91.91 \\
2.16 \\
\end{array}$ \\
\hline \multicolumn{5}{|c|}{ Summary of A11 Phase III Tests } \\
\hline $\begin{array}{l}\text { Mean } \\
\text { Range }\end{array}$ & $\begin{array}{r}12.331 \\
6.662\end{array}$ & $\begin{array}{l}9.98 \\
4.85\end{array}$ & $\begin{array}{r}110.771 \\
15.247\end{array}$ & $\begin{array}{r}90.02 \\
4.85\end{array}$ \\
\hline \multicolumn{5}{|c|}{ Phase II Tests - Unfueled HTGR Elements } \\
\hline \multicolumn{5}{|c|}{ H-327 Graphite - FSV Standard Fue1 Elements } \\
\hline $\begin{array}{l}U E-52 B \\
U E-53 \\
\text { UE-54 } \\
\text { Mean } \\
\text { Range }\end{array}$ & $\begin{array}{r}14.546 \\
14.839 \\
15.302 \\
14.896 \\
0.756\end{array}$ & $\begin{array}{r}16.59 \\
17.17 \\
17.17 \\
16.98 \\
0.58 \\
\end{array}$ & $\begin{array}{r}73.116 \\
71.595 \\
73.800 \\
72.837 \\
2.205 \\
\end{array}$ & $\begin{array}{r}83.41 \\
82.83 \\
82.83 \\
83.02 \\
0.58 \\
\end{array}$ \\
\hline \multicolumn{5}{|c|}{ H-451 Graphite - LHTGR Standard Fue1 Elements } \\
\hline $\mathrm{UE}-55$ & 12.008 & 13.43 & 77.400 & 86.57 \\
\hline \multicolumn{5}{|c|}{ Summary of Phase II Tests } \\
\hline $\begin{array}{l}\text { Mean } \\
\text { Range }\end{array}$ & $\begin{array}{r}14.174 \\
3.294\end{array}$ & $\begin{array}{r}16.09 \\
3.74\end{array}$ & $\begin{array}{r}73.578 \\
5.805\end{array}$ & $\begin{array}{r}83.91 \\
3.74\end{array}$ \\
\hline
\end{tabular}

(a) Not included in means due to abnormal operating conditions. 


\subsection{PRODUCT CHARACTERISTICS}

After veighing to determine the relative distribution of screener and oversize crusher products, each was reduced in a 12 to 1 sample splitter to obtain a suitably sized sample for subsequent screen analysis to determine the product size distribution. The weight percent of material in each of the fractions and the cumulative weight percent less than each size were determined from the screening results. To obtain an estimate of what the combined screener and oversize crusher product size distributions (i.e., system product) would be, the composites were calculated using the screen analysis and the relative quantities of the two products. These analyses and the earlier analysis of products obtained from crushing unfueled HTGR elements (phase II tests) provided the following information:

1. Comparison of the screener product size distribution obtained by crushing various types of fueled HTGR elements.

2. Comparison of the oversize crusher product size distribution obtained by crushing various types of fueled HTGR elements.

3. Comparison of the estimated system product size distributions (composites) obtained by crushing various types of fueled HTGR elements.

4. Comparison of screener, oversize crusher, and system product size distributions obtained by crushing fueled elements with those obtained by crushing unfueled elements.

5. Comparison of the estimated sytem product size distributions (composites) obtained by crushing various types of fueled HTGR elements with estimated primary bumer fuel size distribution requirements. 
TABLE 6-3

SCREENER PRODUCT - PHASE III TESTS - FUELED HTGR ELEMENTS

\begin{tabular}{|c|c|c|c|c|c|c|c|c|c|c|}
\hline \multirow[b]{2}{*}{$\begin{array}{l}\text { Test } \\
\text { No. }\end{array}$} & \multicolumn{10}{|c|}{ Wt $\%$ of } \\
\hline & +4750 & $\begin{array}{r}-4750 \\
+4000\end{array}$ & $\begin{array}{l}-4000 \\
+2800\end{array}$ & $\begin{array}{l}-2800 \\
+2000\end{array}$ & $\begin{array}{r}-2000 \\
+1000\end{array}$ & $\begin{array}{l}-1000 \\
+850\end{array}$ & $\begin{array}{r}-850 \\
+475\end{array}$ & $\begin{array}{l}-425 \\
+355\end{array}$ & $\begin{array}{l}-355 \\
+250\end{array}$ & -250 \\
\hline \multicolumn{11}{|c|}{ H-327 Graphite - FSV Standard Fuel } \\
\hline UL-58 & 0 & 2.5 & 21.0 & 11.5 & 15.2 & 4.9 & 34.5 & 1.8 & 2.1 & 6.5 \\
\hline$U L-59$ & 0 & 1.9 & 17.8 & 10.8 & 16.4 & 5.3 & 37.0 & 2.2 & 2.3 & 6.3 \\
\hline $\mathrm{UL}-60$ & 0 & 2.1 & 16.6 & 11.1 & 17.4 & 5.5 & 35.9 & 2.1 & 2.5 & 6.8 \\
\hline Mean & 0 & 2.2 & 18.5 & 11.1 & 16.3 & 5.2 & 35.8 & 2.0 & 2.3 & 6.5 \\
\hline Range & 0 & 0.6 & 4.4 & 0.7 & 2.2 & 0.6 & 2.5 & 0.4 & 0.4 & 0.5 \\
\hline
\end{tabular}

H-327 Graphite - FSV Control Rod Element - TRISO-TRISO Fueled

\begin{tabular}{l|l|l|l|l|l|l|l|l|l|l|}
\hline $\mathrm{UL}-61$ & 0 & 2.9 & 22.7 & 15.3 & 21.0 & 4.8 & 22.4 & 2.0 & 2.5 & 6.5 \\
\hline
\end{tabular}

H-451 Graphite - LHTGR Standard Fue1 Elements - TRISO-BISO Fueled

\begin{tabular}{|c|c|c|c|c|c|c|c|c|c|c|}
\hline$U L-64$ (a) & 2.1 & 5.0 & 19.7 & 11.7 & 15.8 & 14.8 & 21.7 & 1.8 & 2.2 & 5.2 \\
\hline UL -65 & 0 & 4.6 & 25.6 & 13.5 & 15.7 & 11.7 & 21.8 & 1.5 & 1.8 & 3.9 \\
\hline$U L-66$ & 0.2 & 3.7 & 25.2 & 13.2 & 15.6 & 10.6 & 22.3 & 1.5 & 2.1 & 5.6 \\
\hline Mean & 0.1 & 4.2 & 25.4 & 13.4 & 15.6 & 11.2 & 22.0 & 1.5 & 2.0 & 4.8 \\
\hline Range & 0.2 & 0.9 & 0.4 & 0.3 & 0.1 & 1.1 & 0.5 & 0 & 0.3 & 1.7 \\
\hline
\end{tabular}

Summary of A11 Tests

\begin{tabular}{l|l|l|l|l|l|l|l|l|l|l|l|l|}
\hline Mean & 0 & 3.1 & 22.2 & 13.3 & 17.6 & 7.1 & 26.7 & 1.8 & 2.3 & 5.9 \\
Range & 0.1 & 2.0 & 6.9 & 4.2 & 5.4 & 6.4 & 13.8 & 0.5 & 0.5 & 1.7 \\
\hline
\end{tabular}

(a) Not included in means due to abnormal operating conditions. 
TABLE 6-3 (Continued)

\begin{tabular}{l|c|c|c|c|c|c|c|c|c|c}
\hline \multirow{2}{*}{$\begin{array}{l}\text { Test } \\
\text { No. }\end{array}$} & \multicolumn{8}{c}{ Cumulative Wt \% Less Than Stated Size (Mesh Size in Microns) } \\
\cline { 2 - 11 } & +4750 & -4750 & -4000 & -2800 & -2000 & -1000 & -850 & -425 & -355 & -250 \\
\hline \multicolumn{8}{c}{ H-327 Graphite - FSV Standard Fuel E1ements - TRISO-TRISO Fueled } \\
\hline UL-58 & 100 & 100 & 97.5 & 76.5 & 65.0 & 49.8 & 44.9 & 10.4 & 8.6 & 6.5 \\
UL-59 & 100 & 100 & 98.1 & 80.3 & 69.5 & 53.1 & 47.8 & 10.8 & 8.6 & 6.3 \\
UL-60 & 100 & 100 & 98.0 & 81.4 & 70.2 & 52.8 & 47.3 & 11.4 & 9.3 & 6.8 \\
Mean & 100 & 100 & 97.9 & 79.4 & 68.2 & 51.9 & 46.7 & 10.9 & 8.8 & 6.5 \\
Range & 0 & 0 & 0.6 & 4.9 & 5.2 & 3.3 & 2.9 & 1.0 & 0.7 & 0.5 \\
\hline
\end{tabular}

\begin{tabular}{|c|c|c|c|c|c|c|c|c|c|c|}
\hline $\mathrm{UL}-61$ & 100 & 100 & 97.1 & 74.5 & 59.2 & 38.3 & 33.5 & 11.1 & 9.0 & 6.6 \\
\hline \multicolumn{11}{|c|}{ H-451 Graphite - LHTGR Standard Fuel Element - TRISO-BISO Fueled } \\
\hline$U L-64^{(a)}$ & 100 & 97.9 & 93.0 & 73.2 & 61.5 & 45.7 & 30.9 & 9.2 & 7.4 & 5.2 \\
\hline UL -65 & 100 & 100 & 95.4 & 69.8 & 56.3 & 40.6 & 29.0 & 7.2 & 5.7 & 3.9 \\
\hline UL-66 & 100 & 99.8 & 96.1 & 70.9 & 57.7 & 42.1 & 31.5 & 9.2 & 7.7 & 5.6 \\
\hline Mean & 100 & 99.9 & 95.8 & 70.4 & 57.0 & 41.4 & 30.2 & 8.2 & 6.7 & 4.8 \\
\hline Range & 0 & 0.2 & 0.7 & 1.7 & 1.4 & 1.5 & 2.5 & 2.0 & 2.0 & 1.7 \\
\hline \multicolumn{11}{|c|}{ Summary of A11 Tests } \\
\hline Mean & 100 & 100 & 96.9 & 74.8 & 61.5 & 43.9 & 36.8 & 10.1 & 8.2 & 6.0 \\
\hline Range & 0 & 0.1 & 2.1 & 9.0 & 11.2 & 13.6 & 16.5 & 2.9 & 2.3 & 1.8 \\
\hline
\end{tabular}

(a) Not included in means due to abnormal operating conditions. 
TABLE 6-4

SCREENER PRODUCTS - PHASE II TESTS - UNFUELED HTGR ELEMENTS

\begin{tabular}{|c|c|c|c|c|c|c|c|c|c|c|}
\hline \multirow[b]{2}{*}{$\begin{array}{l}\text { Test } \\
\text { No. }\end{array}$} & \multicolumn{10}{|c|}{ Wt \% of Screened Fractions (Mesh Sizes in Microns) } \\
\hline & +4750 & $\begin{array}{r}-4750 \\
+4000 \\
\end{array}$ & $\begin{array}{r}-4000 \\
+2800\end{array}$ & $\begin{array}{l}-2800 \\
+2000\end{array}$ & $\begin{array}{l}-2000 \\
+1000\end{array}$ & $\begin{array}{l}-1000 \\
+850\end{array}$ & $\begin{array}{l}-850 \\
+425\end{array}$ & $\begin{array}{r}-425 \\
+355\end{array}$ & $\begin{array}{l}-355 \\
+250\end{array}$ & -250 \\
\hline \multicolumn{11}{|c|}{ H-327 Graphite - FSV Standard Fue1 Elements - Unfueled } \\
\hline$U E-52 B$ & 0.4 & 8.5 & 42.1 & 15.7 & 13.7 & 2.1 & 7.1 & 1.4 & 2.0 & 7.0 \\
\hline $\mathrm{UE}-53$ & 0.9 & 8.6 & 38.9 & 16.8 & 16.5 & 2.5 & 7.2 & 1.3 & 1.5 & 5.8 \\
\hline$U E-54$ & 0.4 & 6.9 & 43.2 & 17.4 & 14.6 & 1.9 & 6.8 & 1.3 & 1.6 & 5.9 \\
\hline Mean & 0.6 & 8.0 & 41.4 & 16.6 & 14.9 & 2.2 & 7.0 & 1.3 & 1.7 & 6.2 \\
\hline Range & 0.5 & 1.7 & 4.3 & 1.7 & 2.8 & 0.6 & 0.4 & 0.1 & 0.5 & 1.2 \\
\hline \multicolumn{11}{|c|}{ H-327 Graphite - FSV Control Rod Elements - Unfueled (Half-Length) } \\
\hline UE-49 & 0.8 & 12.5 & 41.6 & 16.0 & 13.5 & 2.0 & 5.9 & 1.1 & 1.6 & 5.0 \\
\hline \multicolumn{11}{|c|}{ H-451 Graphite - LHTGR Standard Fuel Elements - Unfueled } \\
\hline UE-55 & 3.6 & 13.1 & 38.3 & 13.6 & 14.5 & 2.0 & 6.8 & 1.2 & 1.6 & 5.3 \\
\hline \multicolumn{11}{|c|}{ Summary of A11 Tests } \\
\hline Mean & 1.7 & 11.2 & 40.4 & 15.4 & 14.3 & 2.1 & 6.6 & 1.2 & 1.6 & 5.5 \\
\hline Range & 3.0 & 5.1 & 3.3 & 3.0 & 1.4 & 0.2 & 1.1 & 0.2 & 0.1 & 1.2 \\
\hline
\end{tabular}


TABLE 6-4 (Continued)

\begin{tabular}{|c|c|c|c|c|c|c|c|c|c|c|}
\hline \multirow{2}{*}{$\begin{array}{l}\text { Test } \\
\text { No. }\end{array}$} & & \multicolumn{4}{|c|}{ Cumulative Wt \% Less Than State } & \multicolumn{5}{|c|}{ Size (Mesh Sizes in Microns) } \\
\hline & +4750 & -4750 & -4000 & -2800 & -2000 & -1000 & -850 & -425 & -355 & -250 \\
\hline \multicolumn{11}{|c|}{ H-327 Graphite - FSV Standard Fuel Elements - Unfueled } \\
\hline UE-52B & 100.0 & 99.6 & 91.1 & 49.0 & 33.3 & 19.6 & 17.5 & 10.4 & 9.0 & 7.0 \\
\hline $\mathrm{UE}-53$ & 100.0 & 99.1 & 90.5 & 51.6 & 34.8 & 18.3 & 15.8 & 8.6 & 7.3 & 5.8 \\
\hline UE-54 & 100.0 & 99.6 & 92.7 & 49.5 & 32.1 & 17.5 & 15.6 & 8.8 & 7.5 & 5.9 \\
\hline Mean & 100.0 & 99.4 & 91.4 & 50.0 & 33.4 & 18.5 & 16.3 & 9.3 & 7.9 & 6.2 \\
\hline Range & 0 & 0.5 & 2.2 & 2.6 & 2.7 & 2.1 & 1.9 & 1.8 & 1.7 & 1.2 \\
\hline \multicolumn{11}{|c|}{ H-327 Graphite - FSV Control Rod Elements - Unfueled (Half-Length) } \\
\hline $\mathrm{UE}-49$ & 100.0 & 99.9 & 86.7 & 45.1 & 29.1 & 15.6 & 13.6 & 7.7 & 6.6 & 5.0 \\
\hline \multicolumn{11}{|c|}{ H-451 Graphite - LHTGR Standard Fuel Elements - Unfueled } \\
\hline UE-55 & 100.0 & 96.4 & 83.3 & 45.0 & 31.4 & 16.9 & 14.9 & 8.1 & 6.9 & 5.3 \\
\hline \multicolumn{11}{|c|}{ Summary of All Tests } \\
\hline Mean & 100.0 & 98.6 & 87.1 & 46.7 & 31.3 & 17.0 & 14.9 & 8.4 & 7.1 & 5.5 \\
\hline Range & 0 & 3.5 & 8.1 & 5.0 & 4.3 & 2.9 & 2.7 & 1.6 & 1.3 & 1.2 \\
\hline
\end{tabular}




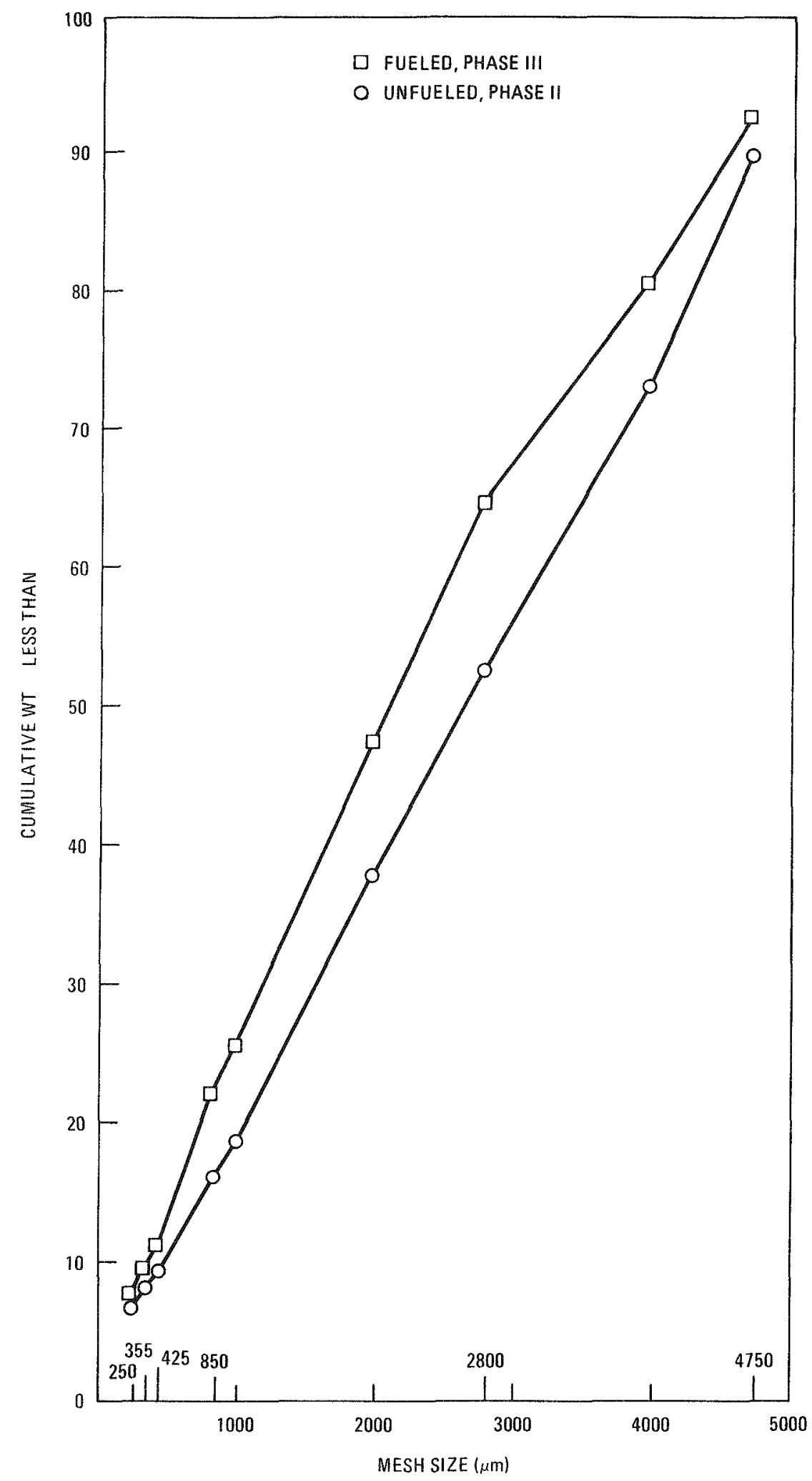

Fig. 6-1. Screener product comparison: phase III tests 


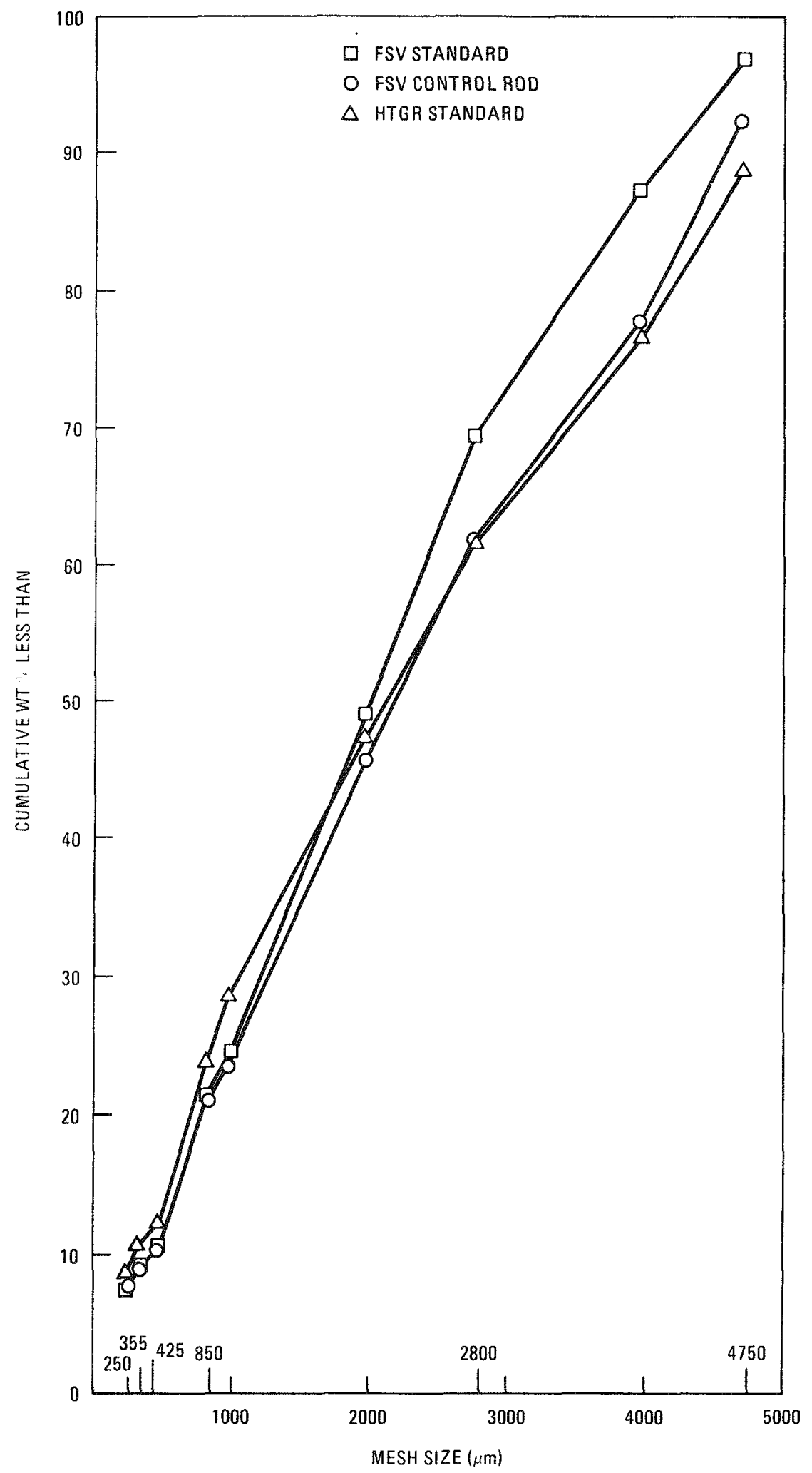

Fig. 6-2. Screener product comparison: phase II and III tests 
TABLE 6-5

OVERSIZE CRUSHER PRODUCT - PHASE III TESTS - FUELED HTGR ELEMENTS

\begin{tabular}{|c|c|c|c|c|c|c|c|c|c|c|}
\hline \multirow[b]{2}{*}{$\begin{array}{l}\text { Test } \\
\text { No. }\end{array}$} & \multicolumn{10}{|c|}{ Wt $\%$ of Screened Fractions (Mesh Size in Microns) } \\
\hline & +4750 & $\begin{array}{l}-4750 \\
+4000\end{array}$ & $\begin{array}{r}-4000 \\
+2800\end{array}$ & $\begin{array}{l}-2800 \\
+2000\end{array}$ & $\begin{array}{l}-2000 \\
+1000\end{array}$ & $\begin{array}{l}-1000 \\
+850\end{array}$ & $\begin{array}{r}-850 \\
+425\end{array}$ & $\begin{array}{l}-425 \\
+355\end{array}$ & $\begin{array}{l}-355 \\
+250\end{array}$ & -250 \\
\hline \multicolumn{11}{|c|}{ H-327 Graphite - FSV Standard Fuel E } \\
\hline $\mathrm{UL}-58$ & 3.5 & 9.6 & 17.6 & 19.4 & 24.9 & 2.9 & 11.6 & 1.5 & 1.8 & 7.2 \\
\hline $\mathrm{UL}-59$ & 3.0 & 9.5 & 17.9 & 21.1 & 24.6 & 2.7 & 10.8 & 1.4 & 1.7 & 7.3 \\
\hline UL-60 & 3.0 & 8.9 & 18.1 & 21.5 & 24.1 & 2.6 & 11.6 & 1.3 & 1.7 & 7.2 \\
\hline Mean & 3.2 & 9.3 & 17.9 & 20.7 & 24.5 & 2.7 & 11.3 & 1.4 & 1.7 & 7.2 \\
\hline Range & 0.5 & 0.7 & 0.5 & 1.1 & 0.8 & 0.3 & 0.8 & 0.2 & 0.1 & 0.1 \\
\hline
\end{tabular}

$\frac{1}{1}$

H-327 Graphite - FSV Control Rod Element - TRISO-TRISO Fueled

\begin{tabular}{|c|c|c|c|c|c|c|c|c|c|c|}
\hline $\mathrm{UL}-61$ & 7.7 & 14.7 & 15.6 & 16.2 & 21.9 & 2.6 & 10.5 & 1.3 & 1.6 & 7.7 \\
\hline \multicolumn{11}{|c|}{ H-451 Graphite - LHTGR Standard Fue1 } \\
\hline$U L-64^{(a)}$ & 14.5 & 15.0 & 18.7 & 15.4 & 15.9 & 2.7 & 6.5 & 1.0 & 1.3 & 9.1 \\
\hline $\mathrm{UL}-65$ & 10.4 & 12.7 & 16.6 & 16.2 & 19.1 & 4.2 & 10.0 & 1.9 & 1.8 & 7.1 \\
\hline UL -66 & 12.2 & 12.3 & 12.9 & 12.1 & 18.5 & 4.9 & 13.4 & 1.4 & 2.0 & 10.2 \\
\hline Mean & 11.3 & 12.5 & 14.8 & 14.2 & 18.8 & 4.6 & 11.7 & 1.6 & 1.9 & 8.6 \\
\hline Range & 1.8 & 0.4 & 3.7 & 4.1 & 0.6 & 0.7 & 3.4 & 0.5 & 0.2 & 3.1 \\
\hline
\end{tabular}

Summary of All Tests

\begin{tabular}{|c|c|c|c|c|c|c|c|c|c|c|}
\hline Mean & 7.4 & 12.2 & 16.1 & 17.0 & 21.7 & 3.3 & 11.2 & 1.4 & 1.7 & 7.8 \\
\hline Range & 8.1 & 5.4 & 3.1 & 6.5 & 5.7 & 2.0 & 1.2 & 0.3 & 0.3 & 1.4 \\
\hline
\end{tabular}


TABLE 6-5 (Continued)

\begin{tabular}{|c|c|c|c|c|c|c|c|c|c|c|}
\hline \multirow{2}{*}{$\begin{array}{l}\text { Test } \\
\text { No. }\end{array}$} & \multicolumn{10}{|c|}{ Cumulative Wt \% Less Than Stated Size (Mesh Size in Microns) } \\
\hline & +4750 & -4750 & -4000 & -2800 & -2000 & -1000 & -850 & -425 & -355 & -250 \\
\hline \multicolumn{11}{|c|}{ H-327 Graphite - FSV Standard Fuel Elements - TRISO-TRISO Fueled } \\
\hline $\mathrm{UL}-58$ & 100 & 96.5 & 86.9 & 69.2 & 49.9 & 24.9 & 22.0 & 10.4 & 9.0 & 7.2 \\
\hline UL-59 & 100 & 97.0 & 87.5 & 69.6 & 48.5 & 23.9 & 21.2 & 10.4 & 9.0 & 7.3 \\
\hline UL -60 & 100 & 97.0 & 88.1 & 70.0 & 48.5 & 24.4 & 21.8 & 10.3 & 9.0 & 7.2 \\
\hline Mean & 100 & 96.8 & 87.5 & 69.6 & 49.0 & 24.4 & 21.7 & 10.4 & 9.0 & 7.2 \\
\hline Range & 0 & 0.5 & 1.2 & 0.8 & 1.4 & 1.0 & 0.8 & 0.1 & 0 & 0.1 \\
\hline \multicolumn{11}{|c|}{ H-327 Graphite - FSV Control Rod Element - TRISO-TRISO Fueled } \\
\hline UL-61 & 100 & 92.3 & 77.5 & 61.9 & 45.7 & 23.7 & 21.1 & 10.6 & 9.3 & 7.7 \\
\hline \multicolumn{11}{|c|}{ H-451 Graphite LHTGR Standard Fuel Elements - TRISO-BISO Fueled } \\
\hline$U L-64^{(a)}$ & 100 & 85.5 & 70.5 & 51.8 & 36.5 & 20.5 & 17.8 & 11.4 & 10.4 & 9.1 \\
\hline UL-65 & 100 & 89.6 & 76.9 & 60.3 & 44.1 & 25.0 & 20.8 & 10.8 & 8.9 & 7.1 \\
\hline UL-66 & 100 & 87.7 & 75.4 & 62.5 & 50.4 & 31.9 & 27.0 & 13.6 & 12.2 & 10.2 \\
\hline Mean & 100 & 88.6 & 76.2 & 61.4 & 47.2 & 28.4 & 23.9 & 12.2 & 10.6 & 8.6 \\
\hline Range & 0 & 1.9 & 1.5 & 2.2 & 6.3 & 6.9 & 6.2 & 2.8 & 3.3 & 3.1 \\
\hline \multicolumn{11}{|c|}{ Summary of All Tests } \\
\hline Mean & 100 & 92.6 & 80.4 & 64.3 & 47.3 & 25.5 & 22.2 & 11.1 & 9.6 & 7.8 \\
\hline Range & 0 & 8.2 & 11.3 & 8.2 & 1.8 & 4.7 & 2.8 & 1.8 & 1.6 & 1.4 \\
\hline
\end{tabular}

(a) Not included in means due to abnormal operating conditions. 
TABLE 6-6

OVERSIZE CRUSHER PRODUCTS - PHASE II TESTS - UNFUELED HTGR ELEMENTS

\begin{tabular}{|c|c|c|c|c|c|c|c|c|c|c|}
\hline \multirow[b]{2}{*}{$\begin{array}{l}\text { Test } \\
\text { No. }\end{array}$} & \multicolumn{10}{|c|}{ Wt \% of Screened Fractions (Mesh Sizes in Microns) } \\
\hline & +4750 & $\begin{array}{l}-4750 \\
+4000\end{array}$ & $\begin{array}{l}-4000 \\
+2800\end{array}$ & $\begin{array}{l}-2800 \\
+2000\end{array}$ & $\begin{array}{l}-2000 \\
+1000\end{array}$ & $\begin{array}{r}-1000 \\
+850\end{array}$ & $\begin{array}{l}-850 \\
+425\end{array}$ & $\begin{array}{l}-425 \\
+355\end{array}$ & $\begin{array}{l}-355 \\
+250\end{array}$ & -250 \\
\hline \multicolumn{11}{|c|}{ H-327 Graphite - FSV Standard Fuel Elements - Unfueled } \\
\hline$U E-52 B$ & 9.6 & 15.4 & 24.3 & 16.4 & 17.9 & 2.1 & 5.9 & 1.0 & 1.3 & 6.1 \\
\hline UE-53 & 5.7 & 12.0 & 21.4 & 17.3 & 21.6 & 2.6 & 7.9 & 1.4 & 1.9 & 8.2 \\
\hline UE-54 & 6.7 & 17.5 & 25.2 & 17.7 & 19.6 & 2.1 & 5.1 & 0.8 & 1.1 & 4.2 \\
\hline Mean & 7.3 & 15.0 & 23.6 & 17.1 & 19.7 & 2.3 & 6.3 & 1.1 & 1.4 & 6.2 \\
\hline Range & 3.9 & 5.5 & 3.8 & 1.3 & 3.7 & 0.5 & 2.8 & 0.6 & 0.8 & 4.0 \\
\hline \multicolumn{11}{|c|}{ H-327 Graphite - FSV Control Rod Elements - Unfueled (Half-Length) } \\
\hline $\mathrm{UE}-49$ & 16.9 & 18.4 & 16.5 & 10.9 & 15.2 & 2.7 & 7.3 & 1.2 & 1.7 & 9.2 \\
\hline \multicolumn{11}{|c|}{ H-451 Graphite - LHTGR Standard Fuel Elements - Unfueled } \\
\hline $\mathrm{UE}-55$ & 9.3 & 16.3 & 21.2 & 14.6 & 23.0 & 2.4 & 6.2 & 0.9 & 1.1 & 5.0 \\
\hline \multicolumn{11}{|c|}{ Sumary of Al1 Tests } \\
\hline Mean & 11.2 & 16.6 & 20.4 & 14.2 & 19.3 & 2.5 & 6.6 & 1.1 & 1.4 & 6.8 \\
\hline Range & 9.6 & 3.4 & 7.1 & 6.2 & 7.8 & 0.4 & 1.1 & 0.2 & 0.6 & 4.2 \\
\hline
\end{tabular}


TABLE 6-6 (Continued)

\begin{tabular}{|c|c|c|c|c|c|c|c|c|c|c|}
\hline \multirow{2}{*}{$\begin{array}{l}\text { Test } \\
\text { No. }\end{array}$} & \multicolumn{10}{|c|}{ Cumulative Wt \% Less Than Stated Size (Mesh Sizes in Microns) } \\
\hline & +4750 & -4750 & -4000 & -2800 & -2000 & -1000 & -850 & -425 & -355 & -250 \\
\hline \multicolumn{11}{|c|}{ H-327 Graphite - FSV Standard Fuel Elements - Unfueled } \\
\hline $\mathrm{UE}-52 \mathrm{~B}$ & 100.0 & 90.4 & 75.0 & 50.7 & 34.3 & 16.4 & 14.3 & 8.4 & 7.4 & 6.1 \\
\hline UE-53 & 100.0 & 94.3 & 82.3 & 60.9 & 43.6 & 22.0 & 19.4 & 11.5 & 10.1 & 8.2 \\
\hline $\mathrm{UE}-54$ & 100.0 & 93.3 & 75.8 & 50.6 & 32.9 & 13.3 & 11.2 & 6.1 & 5.3 & 4.2 \\
\hline Mean & 100.0 & 92.7 & 77.7 & 54.1 & 36.9 & 17.2 & 15.0 & 8.7 & 7.6 & 6.2 \\
\hline Range & 0 & 3.9 & 7.5 & 10.3 & 10.7 & 8.7 & 8.2 & 5.4 & 4.8 & 4.0 \\
\hline \multicolumn{11}{|c|}{ H-327 Graphite - FSV Contro1 Rod Elements - Unfueled (Half-Length) } \\
\hline UE-49 & 100.0 & 85.6 & 66.6 & 49.6 & 38.3 & 22.6 & 19.8 & 12.3 & 11.1 & 9.5 \\
\hline \multicolumn{11}{|c|}{ H-451 Graphite - LHTGR Standard Fuel Elements - Unfueled } \\
\hline UE-55 & 100.0 & 90.7 & 74.4 & 53.2 & 38.6 & 15.6 & 13.2 & 7.0 & 6.1 & 5.0 \\
\hline \multicolumn{11}{|c|}{ Summary of A11 Tests } \\
\hline Mean & 100.0 & 89.7 & 72.9 & 52.3 & 37.9 & 18.5 & 16.0 & 9.3 & 8.2 & 6.9 \\
\hline Range & 0 & 7.1 & 11.1 & 4.5 & 1.7 & 7.0 & 6.6 & 5.3 & 5.0 & 4.5 \\
\hline
\end{tabular}




\subsubsection{Screener Product Size Distributions}

Screener product size distributions from crushing fueled and unfueled HTGR elements are given in Tables $6-3$ and $6-4$, respectively, and the screener product size distributions for various types of fueled elements and for fueled and unfueled elements are compared in Figs. 6-1 and 6-2, respectively. It can be seen that

1. The size distributions of the screener products obtained from fueled FSV control rod elements and LHTGR standard elements are similar; the screener products from FSV standard elements are somewhat finer.

2. The screener products from fueled HTGR elements are considerably finer than those from unfueled elements.

3. The differences in screener products from fueled and unfueled elements in the particle size ranges (i.e., -1000 to $+425 \mu \mathrm{m}$ ) may indicate that the particles, for the most part, do not remain on the matrix.

\subsubsection{Oversize Crusher Product Size Distributions}

Oversize crusher product size distributions from crushing fueled and unfueled HTGR elements are given in Tables 6-5 and 6-6, respectively, and the oversize crusher product size distributions for various types of fueled elements and for fueled and unfueled elements are compared in Figs. 6-3 and 6-4, respectively. It can be seen that

1. As with the screener products, the size distributions of the oversize crusher products from fueled FSV control rod elements and LHTGR standard elements are similar; the oversize crusher products from FSV standard elements are somewhat finer. 


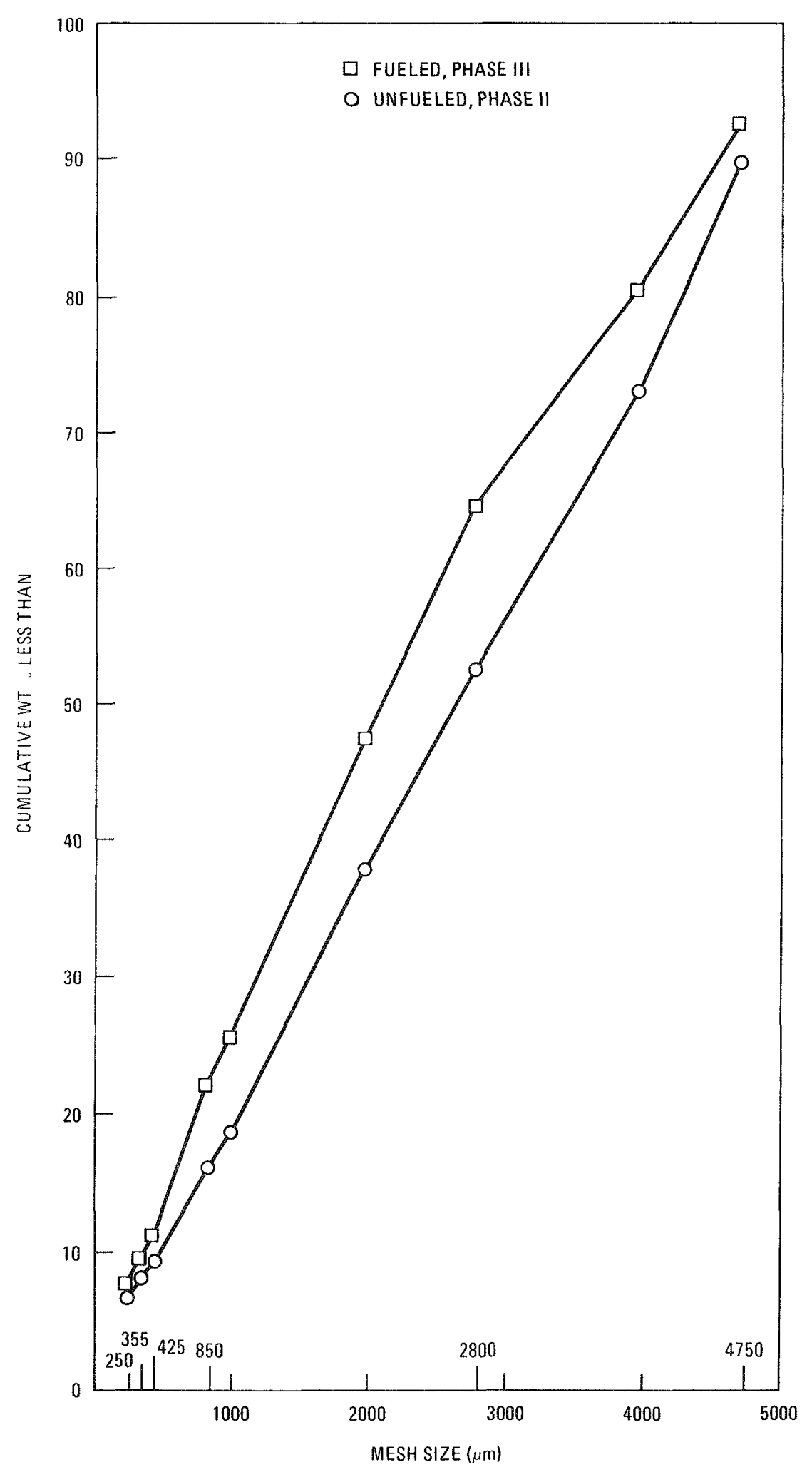

Fig. 6-3. Oversize crusher product comparison: phase III tests 


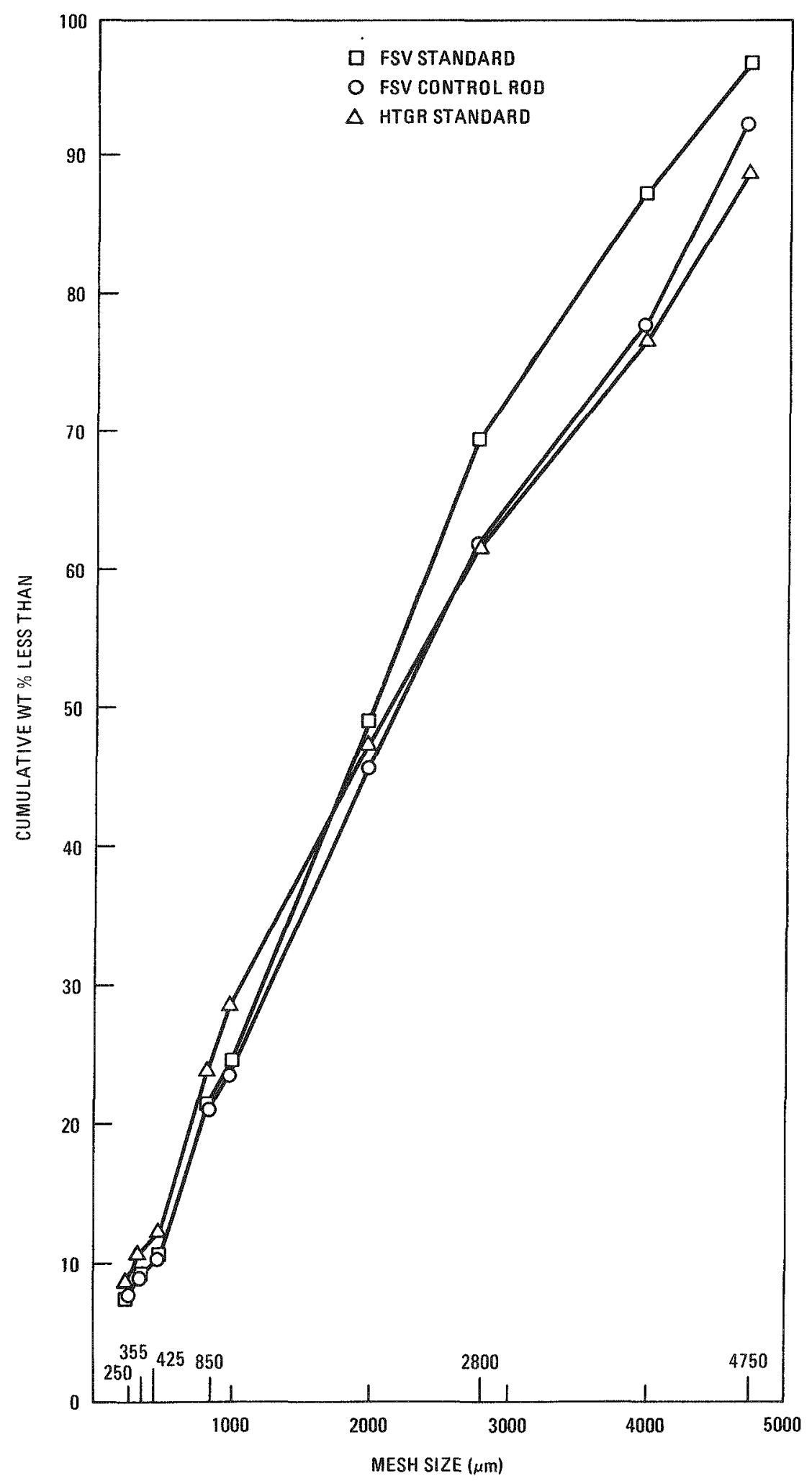

Fig. 6-4. Oversize crusher product comparison: phase II and III tests 
2. The oversize crusher products from fueled HTGR elements are somewhat finer than those from unfueled elements, but the difference is less pronounced than that between the screener products.

\subsubsection{Composite Screener and Oversize Crusher Products}

To obtain an estimate of the size distribution of the size reduction system product, composites were calculated using the product size distributions of the screener and oversize crusher products (Tables 6-3 and 6-5) and the relative quantities of each in the total product (Table 5-2). The estimated system product size distributions obtained from crushing fueled and unfueled HTGR elements are given in Tables $6-7$ and $6-8$, respectively, and the system product size distributions for various types of fueled elements and for fueled and unfueled elements are compared in Figs.6-5 and $6-6$, respectively. It can be seen that

1. The size distributions of products obtained from crushing fueled FSV control rod elements and LHTGR standard elements are similar; the products obtained from FSV standard elements are somewhat finer, as expected from the relationships in the separate screener and oversize crusher products.

2. Again as in the separate products, the system products from fueled HTGR elements are considerably finer than those from unfueled elements.

\subsubsection{Comparison of Crushed Product with Primary Burner Feed Requirements}

Feed requirements for the 6.4-m primary burner have been estimated from tests with a $0.2-\mathrm{m}$ primary burner. This estimate provided a tentative criterion for acceptable primary burner feed. The cumulative weight percents of material less than each stated size obtained from the calculated 
TABLE 6-7

COMPOSITE SCREENER AND OVERSIZE CRUSHER PRODUCTS SIZE DISTRIBUTION PHASE III TESTS - FUEL-LOADED ELEMENTS

\begin{tabular}{|c|c|c|c|c|c|c|c|c|c|c|}
\hline \multirow[b]{2}{*}{$\begin{array}{l}\text { Test } \\
\text { No. }\end{array}$} & \multicolumn{10}{|c|}{ Wt \% of Screened Fractions (Mesh Size in Microns } \\
\hline & +4750 & $\begin{array}{l}-4750 \\
+4000\end{array}$ & $\begin{array}{l}-4000 \\
+2800\end{array}$ & $\begin{array}{l}-2800 \\
+2000\end{array}$ & $\begin{array}{l}-2000 \\
+1000\end{array}$ & $\begin{array}{l}-1000 \\
+850\end{array}$ & $\begin{array}{l}-850 \\
+425\end{array}$ & $\begin{array}{l}-425 \\
+355\end{array}$ & $\begin{array}{l}-355 \\
+250\end{array}$ & -250 \\
\hline \multicolumn{11}{|c|}{ H-327 Graphite - FSV Standard Fuel Elements - TRISO-TRISO Fueled } \\
\hline $\mathrm{UL}-58$ & 0.4 & 3.3 & 20.6 & 12.4 & 16.4 & 4.6 & 31.8 & 1.8 & 2.1 & 6.6 \\
\hline UL -59 & 0.4 & 2.8 & 17.8 & 12.0 & 17.4 & 5.0 & 33.8 & 2.1 & 2.2 & 6.5 \\
\hline$U L-60$ & 0.3 & 2.8 & 16.8 & 12.2 & 18.0 & 5.2 & 33.3 & 2.0 & 2.5 & 6.9 \\
\hline Mean & 0.4 & 3.0 & 18.4 & 12.2 & 17.3 & 4.9 & 33.0 & 2.0 & 2.3 & 6.7 \\
\hline Range & 0.1 & 0.5 & 3.8 & 0.4 & 1.6 & 0.6 & 2.0 & 0.3 & 0.4 & 0.4 \\
\hline \multicolumn{11}{|c|}{ H-327 Graphite - FSV Control Rod Element - TRISO-TRISO Fueled } \\
\hline $\mathrm{UL}-61$ & 0.7 & 4.0 & 22.1 & 15.4 & 21.0 & 4.5 & 21.3 & 1.9 & 2.5 & 6.6 \\
\hline \multicolumn{11}{|c|}{ H-451 Graphite - LHTGR Standard Fuel Elements - TRISO-BISO Fueled } \\
\hline $\mathrm{UL}-64^{(a)}$ & 2.2 & 5.1 & 19.7 & 11.7 & 15.8 & 14.7 & 21.5 & 1.8 & 2.2 & 5.3 \\
\hline UL -65 & 0.9 & 5.3 & 24.7 & 13.8 & 16.0 & 11.0 & 20.7 & 1.6 & 1.8 & 4.2 \\
\hline UL-66 & 1.1 & 4.3 & 24.3 & 13.1 & 15.9 & 10.2 & 21.6 & 1.5 & 2.1 & 5.9 \\
\hline Mean & 1.0 & 4.8 & 24.5 & 13.4 & 16.0 & 10.6 & 21.2 & 1.6 & 2.0 & 5.0 \\
\hline Range & 0.2 & 1.0 & 0.4 & 0.7 & 0.1 & 0.8 & 0.9 & 0.1 & 0.3 & 1.7 \\
\hline \multicolumn{11}{|c|}{ Summary of A11 Tests } \\
\hline Mean & 0.7 & 3.9 & 21.7 & 13.7 & 18.1 & 6.7 & 25.2 & 1.8 & 2.3 & 6.1 \\
\hline Range & 0.6 & 1.8 & 6.1 & 3.2 & 5.0 & 5.7 & 11.8 & 0.4 & 0.5 & 1.7 \\
\hline
\end{tabular}


TABLE 6-7 (Continued)

\begin{tabular}{|c|c|c|c|c|c|c|c|c|c|c|}
\hline \multirow{2}{*}{$\begin{array}{l}\text { Test } \\
\text { No. }\end{array}$} & \multicolumn{10}{|c|}{ Cumulative Wt \% Less Than Stated Size (Mesh Size in Microns) } \\
\hline & +4750 & -4750 & -4000 & -2800 & -2000 & -1000 & -850 & -425 & -355 & -250 \\
\hline \multicolumn{11}{|c|}{$\mathrm{H}-327$} \\
\hline $\mathrm{UL}-58$ & 100 & 99.6 & 96.3 & 75.1 & 63.3 & 46.9 & 42.3 & 10.5 & 8.7 & 6.6 \\
\hline$U L-59$ & 100 & 99.6 & 96.8 & 79.0 & 67.0 & 49.6 & 44.6 & 10.8 & 8.7 & 6.5 \\
\hline$U L-60$ & 100 & 99.7 & 96.9 & 80.1 & 67.9 & 49.9 & 44.7 & 11.4 & 9.4 & 6.9 \\
\hline Mean & 100 & 99.6 & 96.7 & 78.1 & 66.1 & 48.8 & 43.9 & 10.9 & 8.9 & 6.7 \\
\hline Range & 0 & 0.1 & 0.6 & 5.0 & 4.6 & 3.0 & 2.4 & 0.9 & 0.7 & 0.4 \\
\hline
\end{tabular}

H-327 Graphite - FSV Control Rod Element - TRISO-BISO Fueled

\begin{tabular}{|c|c|c|c|c|c|c|c|c|c|c|}
\hline UL-61 & 100 & 99.3 & 95.3 & 73.2 & 57.8 & 36.8 & 32.3 & 11.0 & 9.1 & 6.6 \\
\hline \multicolumn{11}{|c|}{ H-451 Graphite LHTGR Standard Fuel Elements - TRISO-BISO Fueled } \\
\hline$U L-64^{(a)}$ & 100 & 97.8 & 92.7 & 73.0 & 61.3 & 45.5 & 30.8 & 9.3 & 7.5 & 5.3 \\
\hline $\mathrm{UL}-65$ & 100 & 99.1 & 93.8 & 69.1 & 55.3 & 39.3 & 28.3 & 7.6 & 6.0 & 4.2 \\
\hline $\mathrm{UL}-66$ & 100 & 98.9 & 94.6 & 70.3 & 57.2 & 41.3 & 31.1 & 9.5 & 8.0 & 5.9 \\
\hline Mean & 100 & 99.0 & 94.2 & 69.7 & 56.2 & 40.3 & 29.7 & 8.6 & 7.0 & 5.0 \\
\hline Range & 0 & 0.2 & 0.8 & 1.2 & 1.9 & 2.0 & 2.8 & 1.9 & 2.0 & 1.7 \\
\hline \multicolumn{11}{|c|}{ Summary of A11 Tests } \\
\hline Mean & 100 & 99.3 & 95.4 & 73.7 & 60.0 & 42.0 & 35.3 & 10.2 & 8.3 & 6.1 \\
\hline Range & 0 & 0.6 & 2.5 & 8.4 & 9.9 & 12.0 & 14.2 & 2.4 & 2.1 & 1.7 \\
\hline
\end{tabular}

(a) Not included in means due to abnormal operating conditions. 
TABLE 6-8

COMPOSITE SCREENER AND OVERSIZE CRUSHER PRODUCTS SIZE DISTRIBUTION PHASE II TESTS - UNLOADED ELEMENTS

\begin{tabular}{|c|c|c|c|c|c|c|c|c|c|c|}
\hline \multirow[b]{2}{*}{$\begin{array}{l}\text { Test } \\
\text { No. }\end{array}$} & \multicolumn{10}{|c|}{ Wt \% of Screened Fractions (Mesh Size in Microns) } \\
\hline & +4750 & $\begin{array}{l}-4750 \\
+4000\end{array}$ & $\begin{array}{l}-4000 \\
+2800\end{array}$ & $\begin{array}{l}-2600 \\
+2000\end{array}$ & $\begin{array}{l}-2000 \\
+1000\end{array}$ & $\begin{array}{l}-1000 \\
+850\end{array}$ & $\begin{array}{l}-850 \\
+425\end{array}$ & $\begin{array}{r}-425 \\
+355\end{array}$ & $\begin{array}{l}-355 \\
+250\end{array}$ & -250 \\
\hline \multicolumn{11}{|c|}{ H-327 Graphite - FSV Standard Fuel Elements - Unfueled } \\
\hline $\mathrm{UE}-52 \mathrm{~B}$ & 1.9 & 9.7 & 39.1 & 15.8 & 14.4 & 2.1 & 6.9 & 1.4 & 1.9 & 6.8 \\
\hline $\mathrm{UE}-53$ & 1.7 & 9.2 & 35.9 & 16.9 & 17.4 & 2.5 & 7.4 & 1.3 & 1.5 & 6.2 \\
\hline$U E-54$ & 1.5 & 8.7 & 40.1 & 17.4 & 15.5 & 2.0 & 6.5 & 1.2 & 1.5 & 5.6 \\
\hline Mean & 1.7 & 9.2 & 38.4 & 16.7 & 15.8 & 2.2 & 6.9 & 1.3 & 1.6 & 6.2 \\
\hline Range & 0.4 & 1.0 & 4.2 & 1.6 & 3.0 & 0.5 & 0.9 & 0.2 & 0.4 & 1.2 \\
\hline \multicolumn{11}{|c|}{ H-327 Graphite - FSV Control Rod Element - Unfueled } \\
\hline$U E-49$ & 2.2 & 13.0 & 39.4 & 15.7 & 13.6 & 2.0 & 6.0 & 1.1 & 1.6 & 5.4 \\
\hline \multicolumn{11}{|c|}{ H-451 Graphite LHTGR Standard Fuel Element - Unfueled } \\
\hline$U E-55$ & 4.3 & 13.5 & 36.0 & 13.9 & 15.7 & 2.0 & 6.7 & 1.1 & 1.5 & 5.3 \\
\hline \multicolumn{11}{|c|}{ Summary of All Tests } \\
\hline Mean & 2.7 & 11.9 & 37.9 & 15.4 & 15.0 & 2.1 & 6.5 & 1.2 & 1.6 & 5.6 \\
\hline Range & 2.6 & 4.3 & 3.4 & 2.8 & 2.2 & 0.2 & 0.9 & 0.2 & 0.1 & 0.9 \\
\hline
\end{tabular}


TABLE 6-8 (Continued)

\begin{tabular}{|c|c|c|c|c|c|c|c|c|c|c|}
\hline \multirow{2}{*}{$\begin{array}{l}\text { Test } \\
\text { No. }\end{array}$} & \multicolumn{10}{|c|}{ Cumulative Wt \% Less Than Stated Size (Mesh Size in Microns) } \\
\hline & +4750 & -4750 & -4000 & -2800 & -2000 & -1000 & -850 & -425 & -355 & -250 \\
\hline \multicolumn{11}{|c|}{ H-327 Graphite - FSV Standard Fuel Elements - Unfueled } \\
\hline $\mathrm{UE}-52 \mathrm{~B}$ & 100 & 98.1 & 88.4 & 49.3 & 33.5 & 19.1 & 17.0 & 10.1 & 8.7 & 6.8 \\
\hline UE-53 & 100 & 98.3 & 89.1 & 53.2 & 36.3 & 18.9 & 16.4 & 9.0 & 7.7 & 6.2 \\
\hline UE-54 & 100 & 98.5 & 89.8 & 49.7 & 32.3 & 16.8 & 14.8 & 8.3 & 7.1 & 5.6 \\
\hline Mean & 100 & 98.5 & 89.1 & 50.7 & 34.0 & 18.3 & 16.1 & 9.1 & 7.8 & 6.2 \\
\hline Range & 0 & 0.4 & 1.4 & 3.9 & 4.0 & 2.3 & 2.2 & 1.8 & 1.6 & 1.2 \\
\hline \multicolumn{11}{|c|}{ H-327 Graphite - FSV Control Rod Element - Unfueled (Half-Length) } \\
\hline UE-49 & 100 & 97.8 & 84.8 & 45.4 & 29.7 & 16.1 & 14.1 & 8.1 & 7.0 & 5.4 \\
\hline \multicolumn{11}{|c|}{ H-451 Graphite - LHTGR Standard Fuel Element - Unfueled } \\
\hline UE-55 & 100 & 95.7 & 82.2 & 46.2 & 32.3 & 16.6 & 14.6 & 7.9 & 6.3 & 5.3 \\
\hline \multicolumn{11}{|c|}{ Summary of All Tests } \\
\hline Mean & 100 & 97.3 & 85.4 & 47.4 & 32.0 & 17.0 & 14.9 & 8.4 & 7.2 & 5.6 \\
\hline Range & 0 & 2.6 & 6.9 & 5.3 & 4.3 & 2.2 & 2.0 & 1.2 & 1.0 & 0.9 \\
\hline
\end{tabular}




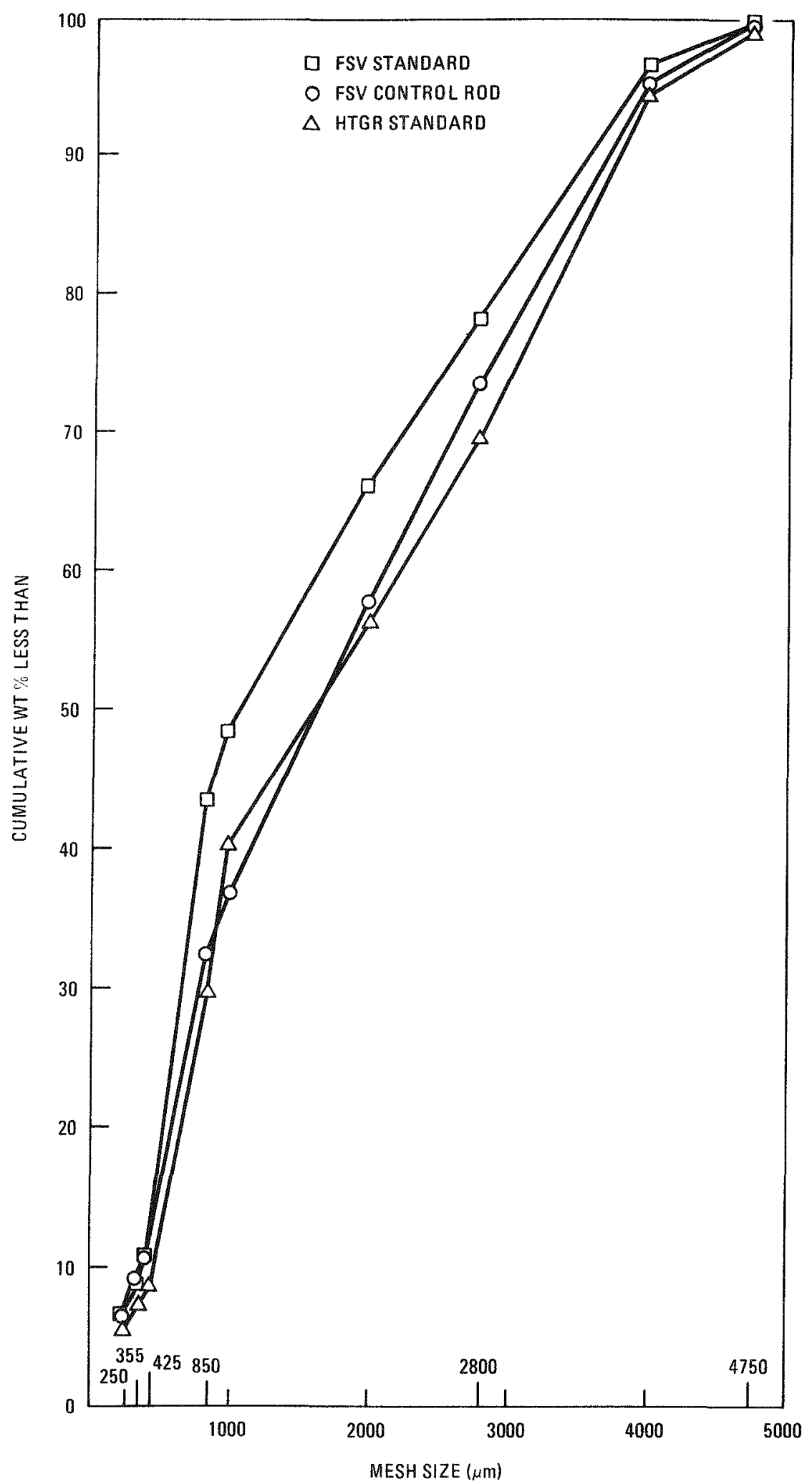

Fig. 6-5. Composite product comparison: phase III tests 


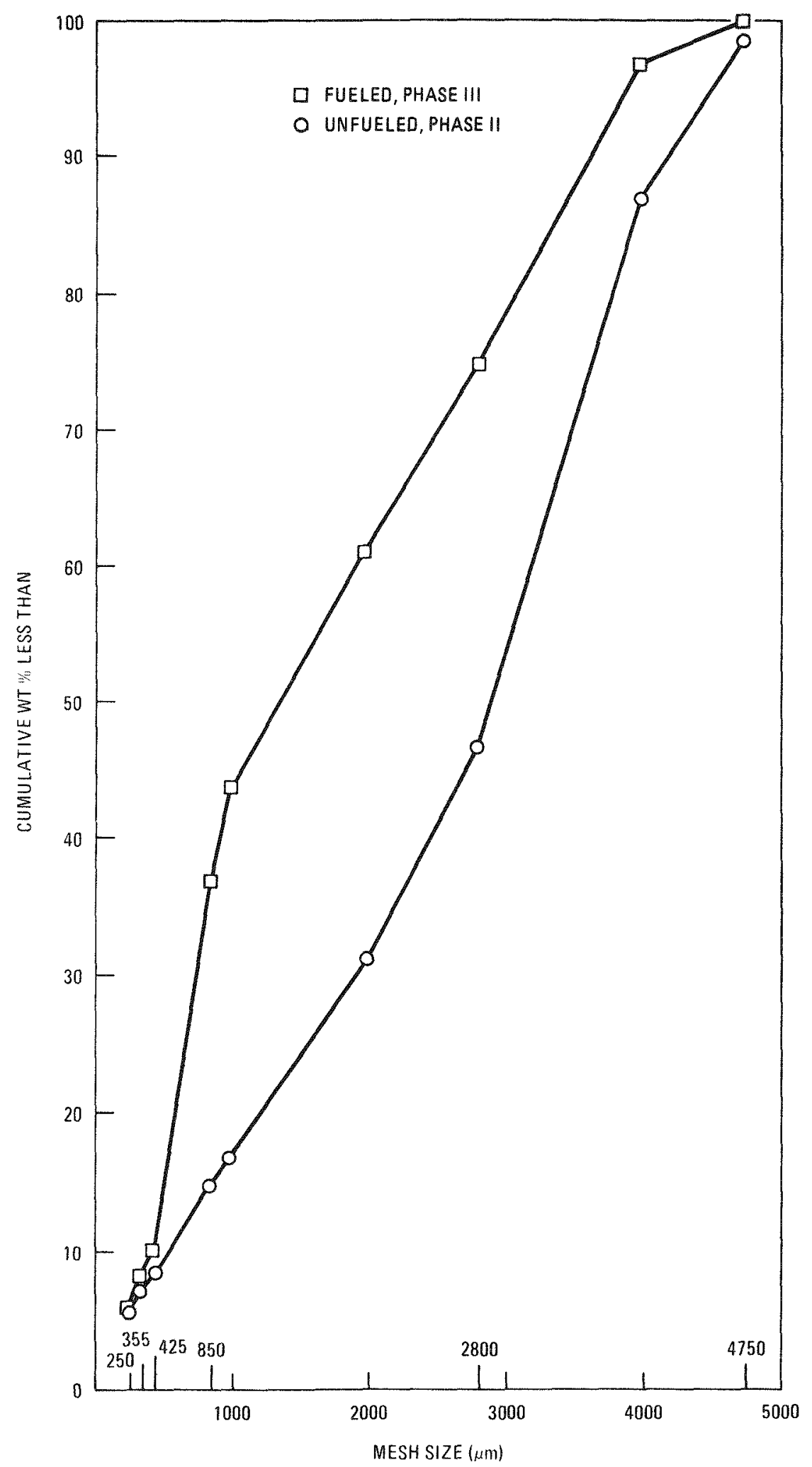

Fig. 6-6. Composite product comparison: phase II and III tests 
composite products from crushing the fueled HTGR elements are given in Table 6-7. Figure 6-7 compares the coarsest product obtained in the phase III tests (i.e., UL-65) with the estimated "acceptable" primary burner feed required. From this comparison, it can be concluded that all the products obtained from crushing any of the types of fueled HTGR elements will easily meet the acceptable primary burner feed requirements as presently defined.

\subsection{PARTICLE BREAKAGE}

\subsubsection{Analytical Procedure}

The following procedure was used to determine the extent of particle breakage resulting from crushing fueled elements in the size reduction sys tem:

1. Screener and oversize crusher products were separately analyzed to establish any additional particle breakage due to oversize crushing.

2. The products were ignited in air at $\sim 900^{\circ} \mathrm{C}$ to remove the burnable carbon and prevent its interference with the subsequent analysis.

3. The residues were leached in thorex solution and analyzed for thorium and uranium content. The results for TRISO/TRISO fueled elements indicate only the thorium and uranium present due to broken paritlcles. However, for BISO/TRISO fueled elements, the results indicate not only the uranium and thorium present from broken particles, but also the total thorium present due to the exposure of the BISO kernel by the ignition process. To obtain an estinate of BISO particle breakage in these fuel elements, it was assumed that the thorium present in the $+425-\mu \mathrm{m}$ mesh fractions was from whole particles and that from the $-425-\mu \mathrm{m}$ mesh fractions, from broken particles. Since whole BISO kernels are 


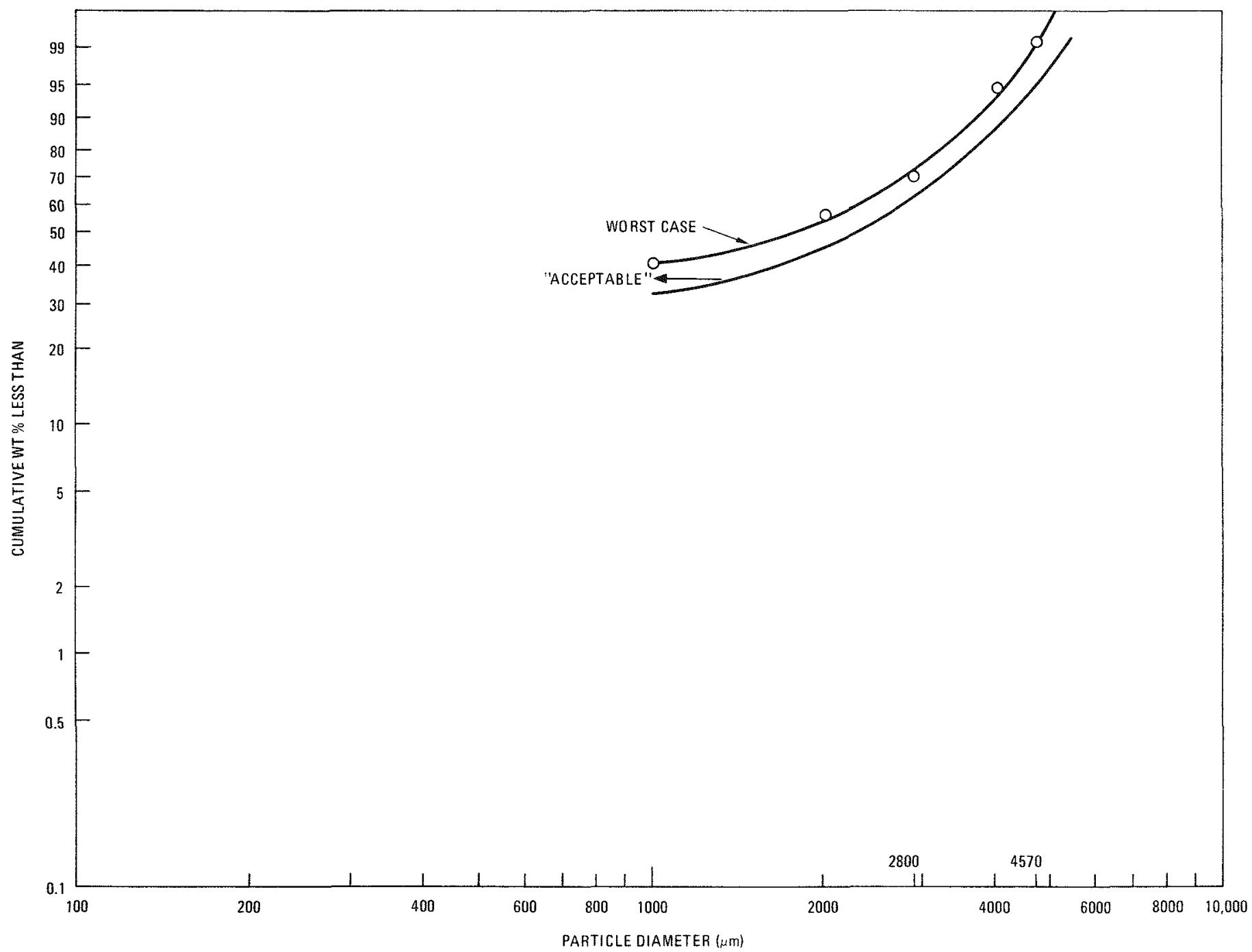

Fig. 6-7. Comparison of composite product with "acceptable" burner feed 
larger than $425 \mu \mathrm{m}$ and crossover after air classification was expected to be almost entirely from fragments less than $425 \mu \mathrm{m}$ in size, this assumption was considered reasonable.

4. The residues from the initial thorex leach were dried, crushed, and reburned in air at $\sim 900^{\circ} \mathrm{C}$ to remove the inner carbon coatings.

5. The residues from reburning were leached in thorex solution and analyzed for thorium and uranium content. The results indicate the amount of thorium and uranium present from whole particles (except BISO particles). The percent of broken particles was calculated from these results and results of the initial leaching.

\subsection{2. $\quad$ Results}

Ificroscopic examination of the product from the initial test (UL-64) on LHTGR elements revealed very few particles in the rod matrix fragments. One rod matrix fragment containing several particles was examined further and found to be quite friable, indicating that possibly little, if any, intact rod matrix with fuel particles would be present after pneumatic transport of UNIFRAME products.

To obtain an estimate of the quantity of particles which existed as individual particles in the crushed product and those which were present in fragments of rod matrix, each mesh fraction from test UL-64 was analyzed by the procedure described in Section 6.9.1. The data obtained are given in Table 6-9. The majority of the thorium and uranium was found in the mesh fractions which were of particle size or smaller (i.e., $<990 \mu \mathrm{m}$ for thorium particles and $<800 \mu \mathrm{m}$ for uranium particles). The thorium and uranium contained in these fractions represented $78 \%$ and $73 \%$, respectively, of the total in the product. Thus, it could be assumed that these particle percentages exist individually, and large agglomerates are unlikely. The data 
TABLE 6-9

PARTICLE BREAKAGE ANALYSIS: TEST UL-64, LHTGR H-451 GRAPHITE TRISO/BISO FUEL ELEMENT

\begin{tabular}{|c|c|c|c|c|c|c|}
\hline $\begin{array}{c}\text { Mesh Fraction } \\
(\mu \mathrm{m})\end{array}$ & $\begin{array}{l}\% \text { Burnable } \\
\text { Carbon }\end{array}$ & $\begin{array}{l}\text { Wt \% } \\
\text { Thorium }\end{array}$ & $\begin{array}{c}\% \text { Broken } \\
\text { Fertile } \\
\text { Particles }\end{array}$ & $\begin{array}{c}\text { Wt \% } \\
\text { Uranium }\end{array}$ & $\begin{array}{l}\% \text { Broken } \\
\text { Fissile } \\
\text { Particle }\end{array}$ & $\begin{array}{l}\text { Th/U } \\
\text { Ratio }\end{array}$ \\
\hline \multicolumn{7}{|c|}{ Screener Product } \\
\hline+4000 & 100 & 0 & 0 & 0 & 0 & 0 \\
\hline$-4000+2800$ & 98.31 & 1.12 & 0 & 0.08 & 1.83 & 14 \\
\hline$-2800+2000$ & 89.88 & 6.50 & 0 & 0.46 & 1.13 & 14 \\
\hline$-2000+1000$ & 82.48 & 11.34 & 0 & 0.78 & 0.83 & 14 \\
\hline$-1000+850$ & 54.66 & 37.37 & 0 & 0.40 & 1.03 & 93 \\
\hline$-850+425$ & 55.70 & 20.69 & 0 & 3.03 & 1.09 & 7 \\
\hline-425 & 98.70 & 1.93 & 100 & 0.17 & 99.00 & 11 \\
\hline Total & 79.25 & 12.84 & 0.32 & 0.92 & 2.74 & 14 \\
\hline \multicolumn{7}{|c|}{ Oversize Crusher Product } \\
\hline+1000 & 99.88 & 0.006 & 0 & 0.02 & 2.97 & 0.3 \\
\hline$-1000+425$ & 87.13 & 8.45 & 0 & 0.56 & 3.06 & 15 \\
\hline-425 & 98.57 & 0.51 & 100 & 0.12 & 63.50 & 4 \\
\hline Total & 98.54 & 0.85 & 7.02 & 0.08 & 12.99 & 11 \\
\hline \multicolumn{7}{|c|}{ Test Product Totals } \\
\hline Al1 & 79.39 & 12.75 & 0.32 & 0.91 & 2.74 & 14 \\
\hline \multicolumn{7}{|c|}{ Screener Product $+425-\mu \mathrm{m}$ Mesh Fraction } \\
\hline$U L-65$ & 83.81 & 13.63 & 0 & 0.65 & 0.25 & 21 \\
\hline UL-66 & 79.06 & 13.56 & 0 & 0.75 & 0.27 & 18 \\
\hline Mean & 81.44 & 13.60 & 0 & 0.70 & 0.26 & 20 \\
\hline \multicolumn{7}{|c|}{ Screener Product $-425-\mu \mathrm{m}$ Mesh Fraction } \\
\hline$U L-65$ & 97.93 & 1.20 & 100 & 0.13 & 99.61 & 9 \\
\hline UL- 66 & 98.42 & 0.64 & 100 & 0.18 & 99.91 & 4 \\
\hline Mean & 98.18 & 0.92 & 100 & 0.16 & 99.76 & 6 \\
\hline
\end{tabular}


TABLE 6-9 (Continued)

\begin{tabular}{|c|c|c|c|c|c|c|}
\hline $\begin{array}{c}\text { Mesh Fraction } \\
(\mu \mathrm{m})\end{array}$ & $\begin{array}{l}\text { \% Burnable } \\
\text { Carbon }\end{array}$ & $\begin{array}{l}\text { Wt \% } \\
\text { Thorium }\end{array}$ & $\begin{array}{l}\% \text { Broken } \\
\text { Fertile } \\
\text { Particles }\end{array}$ & $\begin{array}{l}\text { Wt \% } \\
\text { Uranium }\end{array}$ & $\begin{array}{l}\% \text { Broken } \\
\text { Fissile } \\
\text { Particle }\end{array}$ & $\begin{array}{l}\mathrm{Th} / \mathrm{U} \\
\text { Ratio }\end{array}$ \\
\hline \multicolumn{7}{|c|}{ Screener Product Totals } \\
\hline$U L-65$ & 84.67 & 12.86 & 0.58 & 0.62 & 1.58 & 21 \\
\hline$U L-66$ & 80.86 & 12.36 & 0.48 & 0.70 & 2.61 & 18 \\
\hline Mean & 82.77 & 12.61 & 0.53 & 0.66 & 2.10 & 19 \\
\hline \multicolumn{7}{|c|}{ Oversize Crusher Product +425- $\mu \mathrm{m}$ Mesh Fraction } \\
\hline $\mathrm{UL}-65$ & 95.24 & 3.13 & 0 & 0.15 & 0.31 & 21 \\
\hline $\mathrm{UL}-66$ & 89.82 & 6.47 & 0 & 0.46 & 0.66 & 14 \\
\hline Mean & 92.53 & 4.80 & 0 & 0.31 & 0.49 & 18 \\
\hline \multicolumn{7}{|c|}{ Oversize Crusher Product $-425-\mu \mathrm{m}$ Mesh Fraction } \\
\hline UL -65 & 98.91 & 0.53 & 100 & 0.01 & 97.01 & 53 \\
\hline $\mathrm{UL}-66$ & 99.25 & 0.52 & 100 & 0.13 & 99.91 & 4 \\
\hline Mean & 99.10 & 0.53 & 100 & 0.07 & 98.46 & 28 \\
\hline \multicolumn{7}{|c|}{ Oversize Crusher Product Totals } \\
\hline UL -65 & 95.71 & 2.81 & 2.36 & 0.14 & 1.18 & 20 \\
\hline $\mathrm{UL}-66$ & 91.13 & 5.65 & 1.27 & 0.42 & 4.39 & 13 \\
\hline Mean & 93.42 & 4.23 & 1.92 & 0.28 & 3.04 & 17 \\
\hline \multicolumn{7}{|c|}{ Test Product Totals } \\
\hline UL-65 & 85.68 & 11.94 & 0.62 & 0.58 & 1.57 & 21 \\
\hline UL -66 & 81.58 & 11.89 & 0.51 & 0.68 & 2.71 & 17 \\
\hline Mean & 83.63 & 11.92 & 0.57 & 0.63 & 2.14 & 19 \\
\hline
\end{tabular}


in Table 6-9 also indicate fissile particle breakage in each fraction and the estimated fertile particle breakage for this test. Total particle breakage was $2.74 \%$ of the fissile fraction and estimated at $0.32 \%$ of the fertile fraction.

The initial thorium-to-uranium ratio in the fuel element was $\sim 15$. The ratio for each mesh fraction is given in Table 6-9. Since this ratio is subject to fluctuation owing to sampling and analytical errors and is in mesh fractions where the quantities are very small, only gross changes were considered significant. As expected, the larger proportion of thorium is in the BISO particle size fraction (i.e., -1000 to $+850 \mu \mathrm{m}$ ), and the smaller proportion is in the TRISO particle size fraction (i.e., -850 to $+425 \mu \mathrm{m})$, another indication that the particles exist individually in the product.

Particle breakage data for the succeeding two tests on LHTGR fuel are given in Table 6-10. Particle breakage for these tests averaged $0.57 \%$ of the fertile fraction and $2.14 \%$ of the fissile fraction. On the average, the particle breakage for the three tests on LHTGR elements compares favorably with the $\leq 0.8 \%$. fertile and $<2.6 \%$ fissile broken particle criteria. However, individual test results somewhat exceeded the criterion for the fissile particles. In all cases, particle breakage in the tests with FSV standard and control rod elements was within the $<2.6 \%$ criterion for fissile particles but exceeded the $\leq 0.8 \%$ criterion for fertile particles. The data for these tests are also given in Table 6-10. In all the tests, the particle breakage was generally greater in the products from the oversize crusher, as expected. However, the majority of the particles passed through the screener, and therefore the 1ikelihood that breakage in the oversize crusher would increase overall breakage was small.

\subsection{PHASE III ACCEPTANCE CRITERIA}

The fuel element size reduction system met all the acceptance criteria throughout the tests except for FSV TRISO fertile particle breakage and the 
TABLE $6-10$

PARTICLE BREAKAGE ANALYSIS

FSV H-357 GRAPHITE - TRISO-TRISO FUEL ELEMENTS

\begin{tabular}{|c|c|c|c|c|c|c|}
\hline $\begin{array}{l}\text { Test } \\
\text { No. }\end{array}$ & $\begin{array}{l}\text { \% Burnable } \\
\text { Carbon }\end{array}$ & $\begin{array}{l}\text { Wt \% } \\
\text { Thorium }\end{array}$ & $\begin{array}{c}\% \text { Broken } \\
\text { Fertile }\end{array}$ & $\begin{array}{l}\text { Wt \% } \\
\text { Uranium }\end{array}$ & $\begin{array}{c}\% \text { Broken } \\
\text { Fissile }\end{array}$ & $\begin{array}{l}\text { Th/U } \\
\text { Ratio }\end{array}$ \\
\hline \multicolumn{7}{|c|}{ Screener Product +425 Mesh Fraction } \\
\hline $\mathrm{UL}-58$ & 69.33 & 15.38 & 8.28 & 0.29 & 0 & 53 \\
\hline UL -59 & 67.87 & 12.11 & 14.85 & 0.86 & 0 & 14 \\
\hline $\mathrm{UL}-60$ & 68.69 & 11.08 & 8.99 & 0.69 & 0.45 & 16 \\
\hline Mean & 68.63 & 12.86 & 10.71 & 0.61 & 0.15 & 28 \\
\hline \multicolumn{7}{|c|}{ Screener Product -425 Mesh Fraction } \\
\hline $\mathrm{UL}-58$ & 95.98 & 2.00 & 99.80 & 0.01 & 98.77 & 200 \\
\hline $\mathrm{UL}-59$ & 97.29 & 0.88 & 79.81 & 0.08 & 95.75 & 11 \\
\hline UL-60 & 96.51 & 1.25 & 100.0 & 0.11 & 98.58 & 11 \\
\hline Mean & 96.59 & 1.38 & 93.20 & 0.07 & 97.70 & 74 \\
\hline \multicolumn{7}{|c|}{ Screener Product Totals } \\
\hline UL-58 & 72.10 & 13.99 & 9.64 & 0.26 & 0.55 & 54 \\
\hline UL-59 & 70.88 & 10.96 & 15.39 & 0.78 & 1.03 & 14 \\
\hline UL- 60 & 71.88 & 9.95 & 10.30 & 0.62 & 2.36 & 16 \\
\hline Mean & 71.62 & 11.63 & 11.78 & 0.55 & 1.31 & 28 \\
\hline
\end{tabular}

Oversize Crusher Product +425 Mesh Fraction

\begin{tabular}{l|l|l|l|l|l|l}
\hline UL-58 & 96.47 & 1.65 & 9.27 & 0.10 & 2.11 & 16 \\
UL-59 & 96.53 & 1.79 & 6.68 & 0.08 & 2.14 & 22 \\
UL-60 & 96.24 & 1.91 & 0.49 & 0.12 & 1.63 & 16 \\
Mean & 96.41 & 1.78 & 5.48 & 0.10 & 1.96 & 18 \\
\hline
\end{tabular}

Oversize Crusher Product -425 Mesh Fraction

\begin{tabular}{l|l|l|l|l|l|l}
\hline UL-58 & 99.12 & 0.29 & 100.0 & 0.01 & 96.30 & 29 \\
UL-59 & 98.34 & 0.31 & 79.63 & 0.05 & 98.97 & 6 \\
UL-60 & 98.42 & 0.70 & 100.0 & 0.06 & 98.97 & 12 \\
Mean & 98.63 & 0.43 & 93.21 & 0.04 & 98.88 & 16
\end{tabular}


TABLE 6-10 (Continued)

\begin{tabular}{|c|c|c|c|c|c|c|}
\hline $\begin{array}{l}\text { Test } \\
\text { No. }\end{array}$ & $\begin{array}{l}\% \text { Burnable } \\
\text { Carbon }\end{array}$ & $\begin{array}{l}\text { Wt \% } \\
\text { Thorium }\end{array}$ & $\begin{array}{r}\% \text { Broken } \\
\text { Fertile }\end{array}$ & $\begin{array}{l}\text { Wt \% } \\
\text { Uranium }\end{array}$ & $\begin{array}{c}\% \text { Broken } \\
\text { Fissile }\end{array}$ & $\begin{array}{l}\text { Th/U } \\
\text { Ratio }\end{array}$ \\
\hline \multicolumn{7}{|c|}{ Screener Product +425 Mesh Fraction } \\
\hline $\mathrm{UL}-61$ & 84.72 & 1.71 & 31.02 & 0.36 & 0.42 & 5 \\
\hline \multicolumn{7}{|c|}{ Screener Product -425 Mesh Fraction } \\
\hline $\mathrm{UL}-61$ & 98.33 & 0.41 & 100 & 0.06 & 98.26 & 7 \\
\hline \multicolumn{7}{|c|}{ Screener Product Totals } \\
\hline $\mathrm{UL}-61$ & 86.17 & 1.58 & 32.94 & 0.33 & 2.20 & 5 \\
\hline \multicolumn{7}{|c|}{ Oversize Crusher Product +425 Mesh Fraction } \\
\hline $\mathrm{UL}-61$ & 96.92 & 1.60 & 9.30 & 0.07 & 1.75 & 23 \\
\hline \multicolumn{7}{|c|}{ Oversize Crusher Product -425 Mesh Fraction } \\
\hline UL-61 & 98.98 & 0.46 & 74.82 & 0.03 & 98.59 & 15 \\
\hline \multicolumn{7}{|c|}{ Oversize Crusher Product Totals } \\
\hline $\mathrm{UL}-61$ & 97.14 & 1.49 & 11.41 & 0.07 & 7.16 & 21 \\
\hline \multicolumn{7}{|c|}{ Test Product Totals } \\
\hline $\mathrm{UL}-61$ & 87.20 & 1.57 & 31.01 & 0.31 & 2.31 & 5 \\
\hline $\begin{array}{l}\text { Test } \\
\text { No. }\end{array}$ & $\begin{array}{l}\% \text { Burnable } \\
\text { Carbon }\end{array}$ & $\begin{array}{l}\text { Wt \% } \\
\text { Thorium }\end{array}$ & $\begin{array}{l}\% \text { Broken } \\
\text { Fertile }\end{array}$ & $\begin{array}{l}\text { Wt \% } \\
\text { Uranium }\end{array}$ & $\begin{array}{c}\% \text { Broken } \\
\text { Fissile }\end{array}$ & $\begin{array}{l}\text { Th/U } \\
\text { Ratio }\end{array}$ \\
\hline \multicolumn{7}{|c|}{ Oversize Crusher Product Totals } \\
\hline UL-58 & 96.74 & 1.51 & 11.11 & 0.09 & 2.73 & 17 \\
\hline $\mathrm{UL}-59$ & 96.71 & 1.64 & 8.09 & 0.08 & 1.64 & 20 \\
\hline $\mathrm{UL}-60$ & 96.46 & 1.78 & 4.55 & 0.11 & 7.29 & 16 \\
\hline Mean & 96.64 & 1.64 & 7.92 & 0.09 & 3.89 & 18 \\
\hline \multicolumn{7}{|c|}{ Test Product Totals } \\
\hline $\mathrm{UL}-58$ & 75.02 & 12.51 & 9.66 & 0.24 & 0.65 & 52 \\
\hline UL -59 & 70.88 & 9.86 & 15.25 & 0.70 & 1.14 & 14 \\
\hline $\mathrm{UL}-60$ & 74.46 & 9.09 & 10.18 & 0.56 & 2.46 & 16 \\
\hline Mean & 73.45 & 10.49 & 11.70 & 0.50 & 1.42 & 27 \\
\hline
\end{tabular}


one instance of holdup in the secondary crusher. Minor design changes required to avert holdup will be investigated and are not considered a major problem. Reduction of FSV TRISO fertile particle breakage may have considerable impact on the design and operation of the system and will require careful investigation. 


\section{PILOT PLANT SEQUENTIAL OPERATION: UNIFRAME SYSTEM}

TESTS WITH FUELED ELEMENTS

The three LHTGR fuel elements which had been crushed during phase III testing plus seventeen elements crushed subsequent to the phase III tests were utilized as feed for a sequential pilot plant operational test. The three elements crushed during phase III testing were charged to the crushed product bunker from storage drums via pneumatic transport. The charging order was

1. Element 023, phase III test UL-65, weight $\sim 117.5 \mathrm{~kg}$.

2. Element 022, phase III test UL-66, weight $\sim 119.9 \mathrm{~kg}$.

3. Element 025, phase III test UL-64, weight $\sim 120.2 \mathrm{~kg}$.

No problems were encountered during transport of the crushed products from UL-65 and 66. However, a blockage occurred in the drum discharge valve during transport of product from UL-64. Investigation revealed that slablike fragments of scrap graphite from the scrap graphite tests were the cause. These fragments had previously been observed as the cause of blockage of the oversize crusher line during the UL-64 crushing operation. The remainder of the drum $(\sim 45 \mathrm{~kg})$ was not charged to the product bunker, and there were no further problems of this type throughout subsequent operations.

Element $001(\sim 120.9 \mathrm{~kg})$ was crushed and transported to the crushed product bunker in the normal mode of the present crusher transport system design. The oversize crusher slot valve was set at $225 \%$ open during crushing. Transport throughout the crushing operation was smooth. However, during the normal clean-out period, the transport gas flow was reduced, which resulted in a temporary line blockage because residual 
product from the oversize crusher entered the transport line when the slot valve was fully opened. The blockage was cleared by increasing the gas flow and tapping on the transport line. The transport gas was kept at running conditions until clean-out was completed in all subsequent tests, and there were no complete line blockages in subsequent tests. Crushing operations were then terminated owing to shutdown of the primary burner.

Crushing operations to provide feed for sequential pilot plant operation resumed after restart of the primary burner. Three elements were individually crushed, with a total run time of $15 \mathrm{~min}$ for clean-out and shutdown for each element. Then, six elements were crushed in rapid succession, with a cleanmout period at the conclusion of crushing of the sixth element. Crushed products from the first three elements were separately stored in the crushed product bunker and separately transported to the prinary burner feed bunker for sampling purposes. Crushed products from the final six elements were combined in the crushed product bunker. ITo equipment or operational problems were encountered until crushing of the final element had been completed. During the clean-out period, bearing overheat on the secondary crusher forced it to shut down. The cause of this problem will be investigated so that it can be considered for the planned upgrading of the primary and secondary crusher lubrication systems.

Because overheating of the secondary crusher outboard bearing could potentially cause it to seize, the subsequent seven size reduction operations were spaced over several days to allow the bearing to cool. There were no interruptions caused by the bearing during the actual size reductions, and no other problems were detected in any of the runs. All crushed products from the seven runs were pneumatically transported to the crushed product bunker for subsequent use as primary burner feed for the sequential operations.

Ilonitoring of the area revealed no radioactive material spills which could be directly attributed to crushing operations. The radiation which 
was detected was essentially at background levels. No activity was detected in the fuel charging area or on the floor at the base of the crusher. Less than $10 \mathrm{dpm} / 200 \mathrm{~cm}^{2}$ of radiation were detected on catwalks and machine surfaces. Data from the sequential crushing operations are given in Table 7-1. 
TABLE $7-1$

SUMMARY OF DATA FROM FUEL ELEMENT SIZE REDUCTION FOR SEQUENTIAL PILOT PLANT OPERATIONS

\begin{tabular}{|c|c|c|c|c|c|}
\hline Element & $\begin{array}{c}\text { Date } \\
\text { Crushed }\end{array}$ & $\begin{array}{l}\text { Weight } \\
(\mathrm{kg})\end{array}$ & $\begin{array}{l}\text { Crushing } \\
\text { Time }\end{array}$ & $\begin{array}{c}\text { Charging Time } \\
\text { From Start } \\
\text { of Run }\end{array}$ & $\begin{array}{l}\text { Time Between } \\
\text { Element } \\
\text { Chargings }\end{array}$ \\
\hline 025 & $\begin{array}{l}6 / 23 / 77 \\
(U L-64)\end{array}$ & 120.2 & Not observed & $N / A^{(a)}$ & $\mathrm{N} / \mathrm{A}$ \\
\hline 023 & $\begin{array}{l}7 ; 15 / 77 \\
(\mathrm{Ui}-63)\end{array}$ & 117.5 & $\begin{array}{l}4 \min 40 \mathrm{~s} \\
\text { (estimated) }\end{array}$ & N/A & $\mathrm{N} / \mathrm{A}$ \\
\hline 022 & $\begin{array}{l}7 / 26 / 77 \\
(U L-64)\end{array}$ & 119.9 & Not observed & $\mathrm{N} / \mathrm{A}$ & $\mathrm{N} / \mathrm{A}$ \\
\hline 001 & $9 / 6 / 77$ & 120.9 & Not observed & $\mathrm{N} / \mathrm{A}$ & $\mathrm{N} / \mathrm{A}$ \\
\hline 002 & $9 / 13 / 77$ & 120.0 & $4 \min 10 \mathrm{~s}$ & $\mathrm{~N} / \mathrm{A}$ & $\mathrm{N} / \mathrm{A}$ \\
\hline 003 & $9 / 13 / 77$ & 120.7 & $4 \mathrm{~min} 12 \mathrm{~s}$ & $\mathrm{~N} / \mathrm{A}$ & $\mathrm{N} / \mathrm{A}$ \\
\hline 004 & $9 / 13 / 77$ & 123.2 & $4 \min 6 \mathrm{~s}$ & $\mathrm{~N} / \mathrm{A}$ & N/A \\
\hline 011 & $9 / 15 / 77$ & 123.6 & $4 \min 4 \mathrm{~s}$ & $\mathrm{~N} / \mathrm{A}$ & $\mathrm{N} / \mathrm{A}$ \\
\hline 012 & $9 / 16 / 77$ & 123.4 & $4 \min 8 \mathrm{~s}$ & $\mathrm{~N} / \mathrm{A}$ & N/A \\
\hline 021 & $9 / 16 / 77$ & 120.9 & $3 \mathrm{~min} 50 \mathrm{~s}$ & $\mathrm{~N} / \mathrm{A}$ & $\mathrm{N} / \mathrm{A}$ \\
\hline 019 & $9 / 19 / 77$ & 122.2 & $4 \min 20 \mathrm{~s}$ & $\mathrm{~N} / \mathrm{A}$ & $\mathrm{N} / \mathrm{A}$ \\
\hline 020 & $9 / 19 / 77$ & 120.9 & $4 \min 4 \mathrm{~s}$ & $\mathrm{~N} / \mathrm{A}$ & $\mathrm{N} / \mathrm{A}$ \\
\hline 024 & $9 / 20 / 77$ & 122.4 & $4 \min 12 \mathrm{~s}$ & $\mathrm{~N} / \mathrm{A}$ & $\mathrm{N} / \mathrm{A}$ \\
\hline $\begin{array}{c}026 \\
\text { rotal }\end{array}$ & $9 / 20 / 77$ & $\begin{array}{l}123.4 \\
856.8\end{array}$ & $4 \min 8 \mathrm{~s}$ & $\mathrm{~N} / \mathrm{A}$ & $\mathrm{N} / \mathrm{A}$ \\
\hline
\end{tabular}

Elements Charged Without Clean-Out Periods In Between

\begin{tabular}{l|l|l|lll|l|l}
005 & $9 / 13 / 77$ & 122.5 & $4 \min 6 \mathrm{~s}$ & 0 & - \\
006 & $9 / 13 / 77$ & 123.8 & $4 \min 16 \mathrm{~s}$ & $6 \min 10 \mathrm{~s}$ & $6 \min 10 \mathrm{~s}$ \\
007 & $9 / 13 / 77$ & 123.6 & $4 \min 20 \mathrm{~s}$ & $11 \min 54 \mathrm{~s}$ & $5 \min 44 \mathrm{~s}$ \\
008 & $9 / 13 / 77$ & 122.7 & $3 \min 46 \mathrm{~s}$ & $17 \min 30 \mathrm{~s}$ & $5 \min 36 \mathrm{~s}$ \\
009 & $9 / 13 / 77$ & 123.2 & $4 \min 10 \mathrm{~s}$ & $23 \min 30 \mathrm{~s}$ & $6 \min 0 \mathrm{~s}$ \\
010 & $9 / 13 / 77$ & 124.1 & $4 \min 30 \mathrm{~s}$ & $28 \min 38 \mathrm{~s}$ & $5 \min 8 \mathrm{~s}$ \\
& & & & &
\end{tabular}

Total time including cleanout $=42 \mathrm{~min}$

(a) $\mathrm{N} / \mathrm{A}=$ not applicable. 


\section{CONCLUSTONS AND RECOMMENDATIONS}

Throughout the initial testing of the fuel element size reduction system, discussions were held with cognizant operatilg, design, and management personnel regarding problems and failures and designs requiring modificam tion, completion, or evaluation. The purpose of these discussions was to produce a final viable design applicable to a commercial reprocessing facility in a hot cell environment. The designs which require modification for hot cell use are basically acceptable but need minor changes for remote operation or long-term commercial use. They do not require changes affecting their basic function. The designs requiring completion for hot cell use are those which either were initially omitted owing to budgetary or scheduling constraints or had potential problem areas in a hot cell but were tolerable for testing with low-level radioactive materials. The designs which require evaluation are those which are controversial in that the changes made represent a fairly radical departure from the initial design or design philosophy.

\subsection{DESIGNS REQ̨UTRING MODIFICATION FOR HOT CELL USE}

Components which require modification for hot cell use are described below. These designs are basically acceptable in that they perform their intended functions, but they require minor changes for remote operation or long-term commercial use.

\subsubsection{Ventilation Enclosure}

In a11 the tests conducted thus far, the ventilation enclosure design has been found to be adequate with respect to dust containment and minimization of dust holdup areas. The current design utilizes standard 
methods and fasteners for attaching the removable panels. Before these attachment methods and fasteners can be used in the commercial hot cell reprocessing facility, they will need to be modified for remote operation and removal. Modifications which include the ventilation enclosure panels as integral parts of the machine frame may also be desirable.

\subsubsection{Crushing Wear Surfaces}

The wear surfaces of the primary and secondary crushers are fabricated of mild steel because of cost considerations and ease of fabrication, and they have the potential to provide wear data. The designs of these surfaces have either been proven to be adequate or have been sufficiently modified so that they perform their functions as required. For long-term and more severe use of a commercial reprocessing facility, it will only be necessary to replace the mild steel surfaces with hardened materials to iprove reliability with respect to wear.

\subsection{DESIGNS REQUIRING COIPLETION FOR HOT CELL USE}

Components which require completion prior to hot cell use are described below. Although these components are considered necessary, some of the designs have not been completed owing to budgetary or scheduling constraints. Some of the designs requiring completion are the result of additional needs identified from test observations.

\subsubsection{Through-the-Ce11-Wa11 Drive System}

The present drive system in the cold pilot plant is defined as the drives necegsary for powering the three size reduction stages, the screener, and the oversize crusher. The primary, secondary, and tertiary crusher drives are mounted on a common structure which is separate from the UNIFRAYE structure. Power is supplied to each crusher by electric motors connected by $V$-belts to the primary and secondary crushers and to each of 
the rolls of the tertiary crusher. The screener is driven by a motion generator which is centrally located within the screener housing and composed of an electric motor with weights eccentrically mounted on each end of its shafts. The oversize crusher is driven by the standard system supplied with the unit. This system is composed of an electric motor mounted on a common frame with the other components and connected by $V$-belts to the eccentric roll.

It was recognized at the onset of the design that a more sophisticated drive system is required for the final UNIFRAME design. The present system was used because budgetary and scheduling considerations precluded the design, purchase, construction, and testing of the more sophisticated system. The present system has been found to be more than adequate for cold pilot plant tests of the UNIFRAME components. However, remote maintenance, replacement, tooling, and radiation effects on motors, V-belts, and lubricants for bearings and gears make it desirable to locate as many of the drive system components outside the hot cell as is practical. This necessitates the design and testing of a through-the-cell-wall drive system prior to hot cell use. Completion of the conceptual design has been scheduled fi $r$ FY-78. The requirements of this design are that it reduce remote maintenance, replacement, and tooling requirements; provide for alignment, realignment, and correction of misalignment during installation, replacement, or repair; avoid failures of the drive components, cell structure, and other UNIFRAIE components due to shock, vibration, and loading; and utilize standard comercially available components wherever possible.

\subsubsection{Start-Under-Load Capability}

The design criterion for the UNIFRAME includes the requirement that each of the components start under loaded conditions. This eliminates the potential need for removing uncrushed or partially crushed materials from the system components in the event of shutdown due to power loss, human error, etc., and inadvertent charging of materials prior to equipment 
start-up. Start-under-load capabilities were not specifically addressed for the present drive system because it was recognized that the more sophisticated drive system required for the hot cell use would present different start-under-1oad conditions. The budgetary and scheduling considerations which prevented development of the more sophisticated drive system also applied to completion of start-under-load capabilities.

During the tests completed to date, several occasions arose which provided opportunities for observing the start-under-load capabilities of the present equipment. AIl equipment except the primary crusher readily started under loaded conditions. It appears that no special designs other than that for the primary crusher will be required to provide start-underload capabilities. Completion of the conceptual design for the startunder-load capability of the primary crusher is scheduled for FY-78.

\subsubsection{Fuel Loading Port}

For cold pilot plant purposes, the method for charging the fuel elements to the UNIFRAME was designed to be compatible with available cranes and fuel lift fixtures, single charging of elements, existing ventilation capabilities, and containment practices for low-level radioactive materials. For the commercial reprocessing facility, the fuel charging system design requirements include (1) provision for storage of several fuel elements; (2) automatic conveying; (3) single-element charging through an air lock compatible with ventilation requirements; (4) handling and charging capabilities for broken fuel elements; (5) interlocks to prevent double chargings; and (6) remote repair capabilities.

\subsubsection{Lubrication Systems}

The present lubrication system in the cold pilot plant comprises the bearings and lubricants necessary for proper operation of the major equipment items of the UNIFRAME. The eccentric shafts of the primary and 
secondary crushers are oil-1ubricated by the standard commercial crusher system, which consists of a central galley and wiper system for lubricating the pitman bushings and separate galley and wiper systems for each of the outboard bushings. The toggle-pin joint connections are lubricated by a dry film coating on each of the shafts. The tertiary double-roll crusher and the oversize crusher have been installed with the manufacturer's standard grease-1ubricated roller bearings.

The only lubrication required in the screener is on the drive motor for the motion generator, which is supplied with standard sealed roller bearings. A recirculating oil system and solid graphite bearings have been proposed as altemative methods of lubricating the eccentric shafts on the primary and secondary crushers; however, the components for these altematives have not been received.

The present lubrication systems contain components which can suffer damage from radiation. The consequences of failure of these components are catastrophic, as with roller bearings. More reliable lubrication techniques are required for a commercial reprocessing facility. The requirements for the final lubrication system design include provisions for remote replenishment and replacement of lubricants; avoidance of catastrophic failures; elimination of potential lubricant leakage; use of radiation-resistant lubricants and component parts; and reduction of remote maintenance, replacement, and tooling requirements.

\subsubsection{Interchangeability of Pitman Parts}

The present designs of the primary and secondary pitmans contain many components, such as toggle assemblies and lubrication system parts, which can be used in either crusher. However, because of the differences in the configurations of the crushing surfaces plus the added feature of being above to remove these surfaces, the machining on the pitman castings renders the castings quite different. For a commercial facility, the need 
for separate replacement parts is undesirable. Therefore, for the final design, efforts will be undertaken to design pitman assemblies which are almost entirely interchangeable, with the exception of the removable crushing surfaces, which must be different.

\subsubsection{Secondary Crusher Clearing Device}

On several occasions during initial testing of the secondary crusher, materials failed to crush completely. Investigation demonstrated that this was mainly related to the angle between the pitman and the stationary $j$ aw crushing surfaces (nip angle). Angles which were too large allowed the material to slip upward in the crushing cavities and thus to remain uncrushed. The preceding tests established that at angles of $14.5 \mathrm{deg}$ or less, unirradiated graphites were easily crushed. By machining the crushing surface on the pitman, the 14.5-deg angle was extended as far up the curved wear surface as practical. In succeeding tests, crushing failure occurred only once in 62 experiments, and this material was readily crushed after its location in the crushing cavity was altered by external means. Even with this low frequency of occurrence, it is desirable to provide a means for clearing uncrushed materials from the secondary crusher because of the potential consequences. Materials held up in this manner could provide sufficient blockage for subsequent material holdup, which would ultimately result in the need to dismantle equipment to clear the cavity, even though material which was held up might be cleared by movement and pressures from subsequent chargings or wear and movement caused by the crushing action of the moving pitman. A clearing device in a final design would be required to exhibit simplicity of operation and minimization of remote maintenance and tooling requirements. It would also be necessary that it produce no effect on normal crushing operations.

\subsubsection{Oversize Crusher}

The preceding tests on the oversize crusher revealed that it did not reduce all the oversize material to $\leq 4780 \mu \mathrm{m}$, as required. This was 
attributed to spring loading of the wear plates, which allows them to be pushed away from the roll by the flow of material between the plates and the eccentric roll, effectively increasing the gap. These gaps are difficult to set properly even under cold pilot plant conditions and would be even more difficult to set under remote conditions. In addition, the crusher design allows material holdup in the cavities behind the wear plates. These factors make it necessary to upgrade the present oversize crusher design and investigate viable altemative designs such as doubleroll crushers.

\subsection{DESIGIS REQUIRING EVALUATION}

The fuel element size reduction system component designs and altemative designs are evaluated below.

\subsubsection{Primary Crusher Clearing Device}

The single occurrence of crushing failure necessitated the requirement for a clearing device in the secondary crusher to avoid potential dismantling of equipment to remove the held-up material. Therefore, the need for a clearing device in the primary crusher was also investigated.

There are several factors which reduce the need for a clearing device in the primary crusher. Platerial holdup in the primary crusher has not been experienced in any of the tests at nip angles of $14.5 \mathrm{deg}$ or less, and it is not known that holdup will occur. Smaller nip angles will increase the probability of crushing and will be incorporated in the final design as fixed angles; otherwise adjustment capabilities will be included. Holdup from one element could be cleared by movement of the fragments or additional loads from the crushing of a subsequent element. For events such as shutdowns prior to completion of crushing, start under load is a design requirement separate from the need for a clearing device. This type of clearing may be possible by reversing the drive on the crusher. 
Avoidance of material holdup is a serious consideration from the standpoint of safeguards and accountability; it is also an operational requirement. However, no clearing device can guarantee that a form of holdup, no matter how unlikely, will not occur. It is also impossible to be certain that the device will be able to clear the holdup without dismantling of the equipment.

The design of a clearing device which is simple and can be easily remotely operated should be completed along with a study of techniques and operations for clearing holdup without such a device. The decision to exclude or include a clearing device in the final commercial hot cell system should be based on considerations of the achievable nip angle in the final design; the simplicity of the clearing device and its failure modes and effects; the start-under-load capabilities, including reversibility of the drive; and the incidence of holdup which occurs in the remaining crusher tests.

\subsubsection{Variable Primary Crusher Nip Angle}

The primary crusher stationary jaw can be adjusted to change the included angle (nip angle) between it and the movable jaw (pitman). This assembly is shown in Fig. 8-1. The primary crusher nip angle is adjusted by loosening the bolts securing the shafts to anchor blocks welded to the machine frame; loosening the locking devices on the adjustment bolts; and turning the adjustment bolts inward or outward until the desired angle is achieved. The inward travel is limited by the clearance between the stationary jaw cheek plates and the pitman face and by the minimum gap allowing a fuel element to enter the crusher. The adjustment outward travel is limited to the maximum allowed by the clearance between the back of the jaw and the adjustment assembly. After the angle has been confirmed by measurement and the shaft securing bolts and the locking devices on the adjustment bolts have been tightened, the crusher is ready to resume normal operation. 


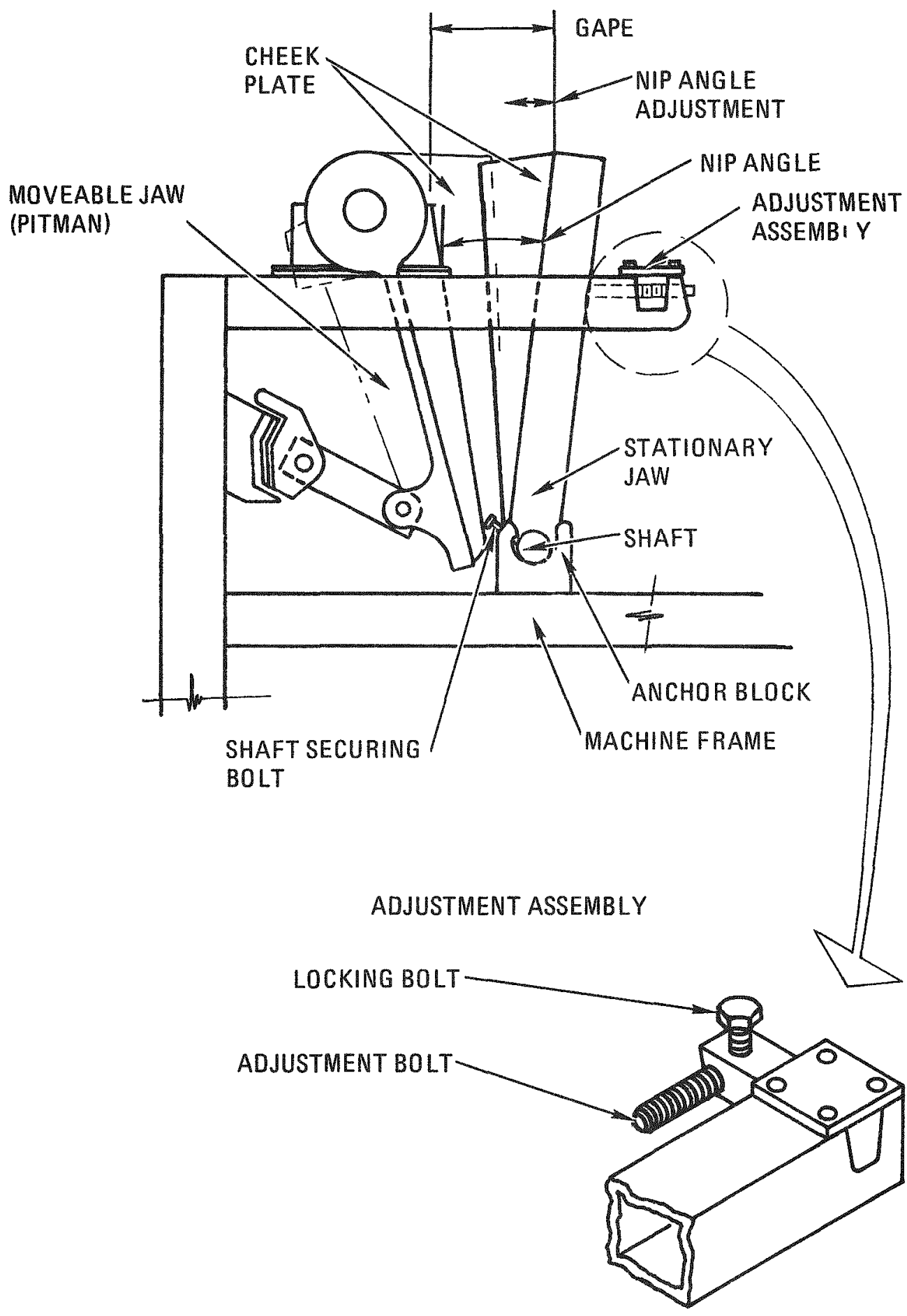

Fig. 8-1. Basic components of primary crusher nip angle adjustment 
This feature of the stationary jaw was considered desirable because the exact nip angles required to crush unirradiated and irradiated fuel elements could not be established for the primary crusher prior to the actual tests. Since then, tests have more clearly identified the nip angle required for crushing unirradiated graphite. Because of the potential benefits of a fixed stationary $j$ aw and the demonstrated desirability of the smallest nip angle practicable, it became desirable to investigate the potential of a fixed nip angle.

As described in Section 8.2.6, failures of materials to crush occurred in the initial individual tests of the primary and secondary crushers. Further investigation of the problem showed that this was mainly related to nip angles which were too large and thus allowed the material to slip upward in the crushing cavities instead of crushing to completion. Phase I of the test series estaulished that at nip angles of $14.5 \mathrm{deg}$ or 1 ess, unirradiated fuel element graphites were readily crushed. A 14-deg nip angle on the primary crusher was selected for use in all the succeeding tests to further increase the probability of crushing to completion. No failures to crush or hold up were experienced in primary crushing or system tests using the 14-deg nip angle.

At any particular CSS, the minimum fixed or variable nip angle on the primary crusher is limited to that providing an opening (gape) between the movable and the stationary jaws at the top of the crusher, which allows a full-size fuel element to enter for crushing. The gape can be expanded by extending the length of the jaws, but this is restricted by practical height limitations. Previous tests have shown that reducing the nip angle increases the probability of complete crushing of the fuel element without material holdup. Therefore, any prudent design of either a fixed or variable nip angle should include the minimum nip angle practicable within the design constraints and should be completed for inclusion in the commercial hot cell system. Since the minimum nip angle practicable maximizes the probability of crushing to completion without material holdup, there are no 
pressing reasons for allowing the larger angles provided by the variable nip angle design. The added complexity of the variable nip angle design, its requirement for additional remote tools, the increased complexity and penetrations in the ventilation enclosure, and the restrictions imposed on the machine frame make it less desirable than a fixed nip angle.

\subsubsection{Removable Primary and Secondary Crusher Stationary Jaws}

The primary and secondary crushers have stationary jaws which are designed to be removable and reversible. The primary crusher stationary jaw can also be adjusted to change the included angle (nip angle) between it and the movable jaw (pitman). These assemblies are shown in Figs. 8-2 and $8-3$.

The primary crusher stationary $\mathrm{j}$ aw is removed by the following general procedure:

1. The necessary sections of the ventilation enclosure are removed.

2. A remote lift fixture is attached to the top of the stationary jaw.

3. The nip angle adjustment assemblies are removed to provide clearance.

4. The bolts which secure the shafts to anchor blocks welded to the machine frame are loosened.

5. The entire assembly is lifted clear of the machine frame using the remote lift fixture.

If the stationary jaw has not mechanically failed but one side cannot be used because of excessive wear on the crushing surfaces, it can be reversed by removing and replacing the cheek plates on the opposite face of the $j a w$. 


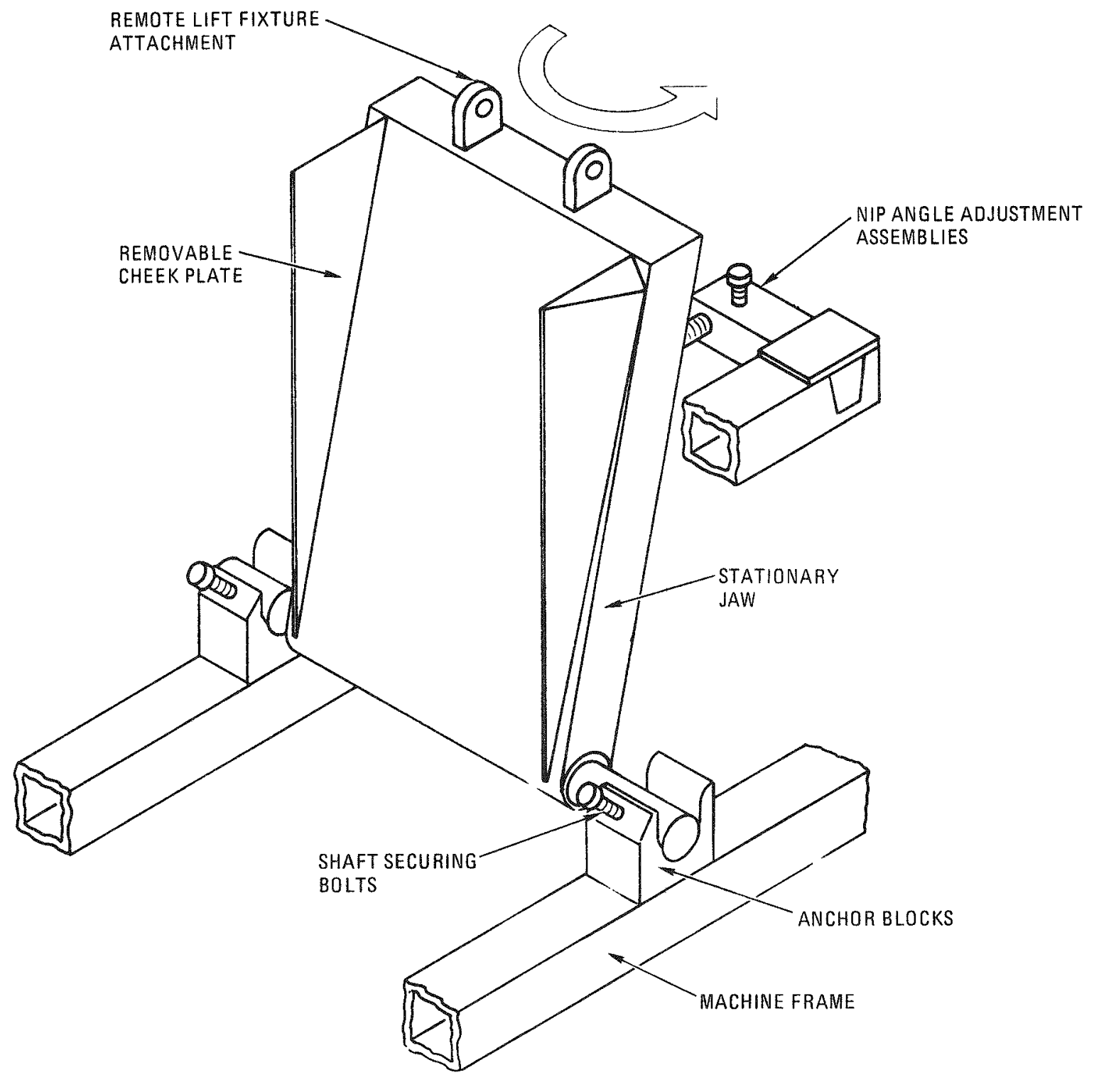

Fig. 8-2. Basic components of removable and reversible primary crusher stationary jaw 


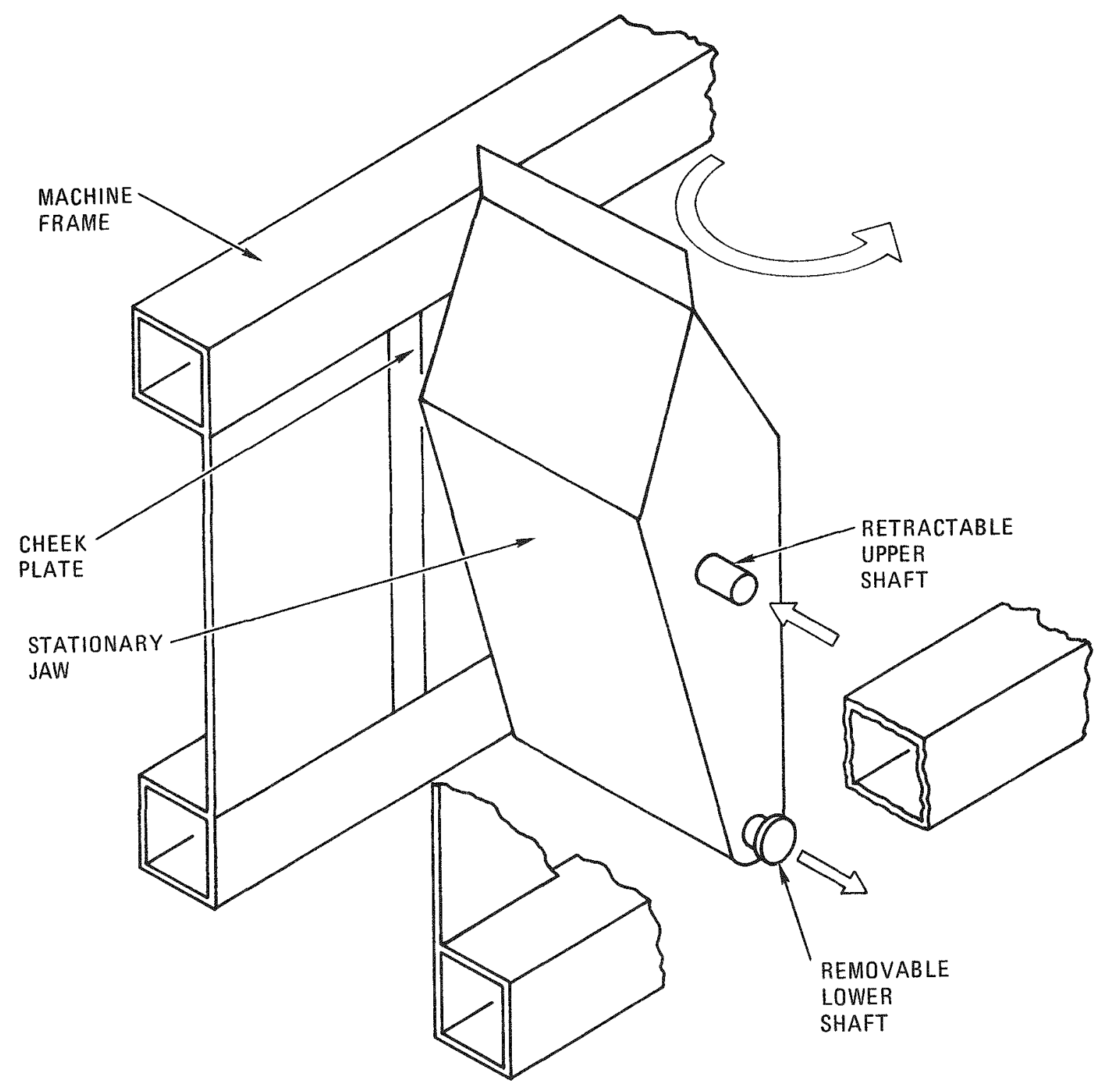

Fig. 8-3. Basic components of removable and reversible secondary crusher stationary jaw 
The secondary crusher stationary $j$ aw is removed by the following general procedure:

1. The necessary sections of the ventilation enclosure are removed.

2. A remote lift fixture is attached to the stationary jaw.

3. The upper shaft assemblies are drawn inward. At this point, the jaw can be laid flat if required.

4. The lower shaft assemblies are removed.

5. The entire assembly is withdrawn from the machine frame using the remote lift fixture.

As with the primary crusher stationary jaw, the secondary crusher stationary jaw can be reversed if it has not mechanically failed but one side cannot be used because of excessive wear on the crushing surfaces.

These features of the stationary jaws are considered to be desirable if it is assumed that wear and other failures will require periodic removal of the jaws. However, since the wear rates have not yet been established and these assemblies are complex and require sophisticated remote fixtures, it is also desirable to investigate the potential for fixed stationary jaws.

The primary and secondary crushers were individually tested (phase I) using unfueled HTGR graphite fuel and control rod elements and were tested with the UNIFRAME as a system using both unfueled (phase II) and fueled (phase III) HTGR fuel and control rod elements and scrap anode butt graphite. Throughout all these tests there were no mechanical failures of either stationary jaw, their removable components, or the primary crusher nip angle adjustment assembly. There was also no obvious bypass of the 
crusher by crushed materials due to the stationary jaw design. Material holdup did not occur on the primary crusher stationary jaw, but, a sma11 quantity of crushed graphite lodged in the gaps between the secondary crusher stationary $j a w$ and the side plates. It was suspected that this lodged material could cause problems with the remote removal of the $j$ aw by blocking the necessary clearance between the jaw and the side plates. The secondary crusher stationary jaw remote removal fixture has not been completed, and therefore there has not been a test of this feature and its associated equipment, nor have potential problems been determined. The primary crusher stationary jaw was removed and replaced using its remote removal fixture. However, this was considered to be a preliminary test, and thorough tests of the removability of both $j$ aws under remote conditions are required.

Tests to date with unirradiated graphites have not been extensive enough to reveal wear on either the primary or the secondary stationary jaw, even though both are presently constructed of mild steel. For more severe commercial use, these mild steel wear surfaces would normally be replaced by hardened materials to improve their life. Since the wear rates from crushing either unirradiated or irradiated fuels have not yet been established, the inclusion of removability and reversibility in the design of the stationary jaws is a precaution and not an established need. For commercial operation, gross wear could be measured in the hot cell during scheduled shutdowns. If wear sufficient to affect the CSS occurred, it could potentially be compensated for by shims on the pitman, providing the strength of the assemblies was not affected.

If the safety factors for failures due to stress can be established incorporated into the design of either fixed or removable jaws, the causes of failures (other than stress or wear) would be related to the number of parts which could fail. The number of parts would necessarily be greater for the removable jaw than for the fixed jaw degigns. It is possible that failures could occur which would render it impossible to repair the removable jaws or their component parts with the remote tools readily available, 
which would necessitate removal of the entire UNIFRAME to repair or replace the components. The fixed jaw designs with no removable components would probably require removal of the entire UNIFRAME for any type of repair.

The additional penetrations and removable panels required in the ventilation enclosure by the removable $j$ aw designs increase the probability of failures in this system and require that remote tooling be available for panel removal. The potential inclusion of one or both stationary jaws as an integral part of the ventilation enclosure in the fixed jaw designs can reduce the probability of ventilation system failures. Accessibility to the other components of the UNIFRAME would probably be greater with the removable jaw design. However, this does not rule out the possibility that access could be achieved and even enhanced with a simple fixed jaw design.

Designs for remote removal fixtures and tools are not complete. These fixtures and tools are required for removal and reversal of the stationary jaws and removal of the ventilation enclosure panels. These fixtures and tools will also be subject to failure, which could render them unavailable when they are needed, and will require tooling for repairs. The additional cell height and floor space requirements for remote removal and remote tool and replacement part storage cannot be determined until all designs are complete. However, these requirements will be greater for the removable jaw design, which will affect overall plant costs.

Because of the limited availability of unirradiated and irradiated fuels for testing, wear which would occur in normal tests may be too difficult to determine accurately or too insufficient for making meaningful design decisions. Therefore, wear tests should be performed using special test equipment which accelerates the time frame and simulates as many of the environmental conditions as practical.

The maximum effective nip angle for crushing irradiated fuels should be determined in hot cell tests which can be related to the preceding 
tests on unirradiated fuels. This would allow meaningful design decisions regarding the secondary crusher nip angle (which is not adjustable in the present design) and the primary crusher nip angle, whether it is adjustable or fixed (as desired). Because the probability of crushing increases as the nip angle decreases, any primary crusher design should allow the minimun nip angle possible within the practical restraints of the height and depth of the fuel element entrance into the crushing cavity.

Designs of fixed stationary jaws with hardened wear surfaces and the smallest practical nip angles for the primary and secondary crushers should be completed at the same time as simplified designs which omit the nip angle adjustment on the primary crusher and reversibility for both crushers but include the ability to remove the wear surfaces (semifixed design). Completion of these designs will allow more detailed comparison of their advantages and disadvantages with those of the removable/reversible designs presently in use as well as an in-depth study of potential failure areas.

The decision on the design to be included in the final commercial hot cell system should be based on wear rate test results and failure modes and effects analysis. High wear rates would point toward the use of the current removable and reversible designs; moderate wear rates, to the semifixed design; and low wear rates, to the fixed design. Wear rates would be gauged on the life requirements of the system. Comparison of failure modes and effects with known wear rates would reveal the optimum design for hot cel1 use and the trade-offs required.

\subsubsection{Fixsed Close Side Settings, Primary and Secondary Crushers}

The CSS of the primary and secondary crushers are defined by the smallest gap at the bottom of each crusher through which the material must pass to reach the next crushing stage. These CSS determine at least one dimension of the fragments passing through and affect the size reduction of the next stage. The components which determine the CSS are illustrated in 
Fig. 8-4. The designs of the primary and secondary crushers are such that the CSS are essentially fixed during inftial installation. However, they may be changed by removing the entire pitman assembly and replacing the toggles with ones of shorter length. The potential need for adjustment of the CSS to compensate for (1) tolerance "stack-up" in the assembly, (2) wear, and (3) difficulties involved in changing the settings make it desirable to investigate the addition of a variable CSS.

There are many variables (such as pillow block, pushing beam, and stationary jaw locations) and machined surface dimensions which determine the exact magnitude of the CSS. Stack-up of the tolerances on these dimensions resulted in initia] CSS discrepancies. Therefore, shims (located between the pushing beam and pushing block) were required during initial installation of the primary and secondary crusher pitman assembiles to obtain the desired CSS. During tests to determine the nip angle required for crushing, various CSS were tested by adding or deleting the shims. As expected, the probability that primary crusher products would be crushed in the secondary crusher increased as the CSS of the primary crusher decreased.

Because of the large number of parts required for the primary and secondary crusher assemblies, there is the potential for CSS errors due to stack-up of tolerances. These errors are difficult to avoid without considerable reduction of the normally allowed tolerances. This could be costly in terms of manufacturing and may require extensive quality assurance surveillance; it may also be unnecessary for the function of the components. The desired CSS can be ensured by installation of simple shims between the pushing beam and the pushing blocks during final assembly. These shims could be permanently fixed in place, and additional shims could be installed later to compensate for wear or differences in the crushing behavior of various types of fuel elements which may affect the CSS. Toggle assemblies and other parts could be made to be interchangeable since the shims would compensate for minor differences between 


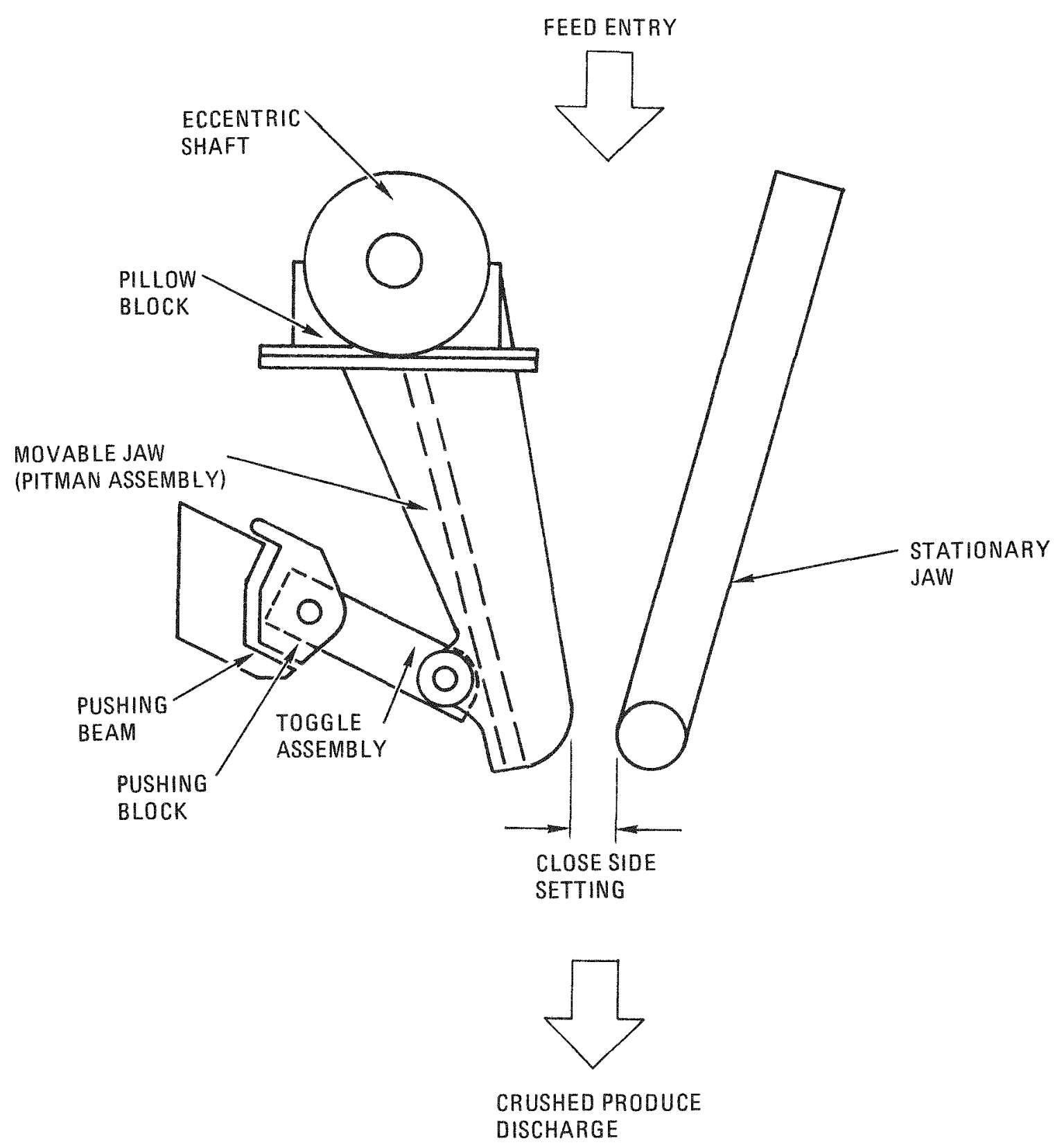

Fig. 8-4. Simplified illustration of components determining the close side setting (typical of primary and secondary crushers) 
the primary and secondary crushers. However, the need for removable toggle assemblies is unavoidable whether or not fixed or adjustable CSS designs are used because of the potential need for repair of these assemblies. The design of shims for adjusting the CSS on the primary and secondary crushers with interchangeable and removable toggle assemblies should be completed and included in the commercial hot cell system.

\subsubsection{Oversize Monitoring System}

The oversize monitoring system consists of a screener, a flow rate sensor, and an oversize crusher, arranged as shown in Fig. 8-5. The screener, shown in Fig. 8-6, operates as follows: crushed materials

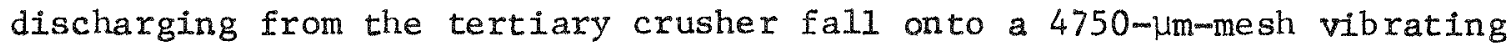
screen; the material passing through the mesh discharges into a cone-shaped housing which directs it into a tube common to the screener and the oversize crusher for pneumatic transport to a product collection bunker; the material which does not pass through the mesh discharges into a chute leading to the flow rate sensor.

The operation of the flow rate sensor, shown in Fig. 8-7, is as follows: crushed materials discharging from the screener chute strike an impact cone suspended by a system of beams; the force of the falling particles causes deflection of the beams; the deflection is converted by strain gauges into an electrical signal proportional to the quantity of material; and the material gravity discharges into the oversize crusher. The oversize crusher, shown in Fig. 8-8, operates as follows: crushed materials discharging from the flow rate sensor are recrushed between two wear plates and an eccentrically mounted roll; the recrushed material discharges into a tube common to the oversize crusher and the screener for pneumatic transport to a product collection bunker. Although the oversize monitoring system is considered to be desirable means of detecting problems in preceding crushing stages and producing crushed product fine enough to be acceptable as primary burner feed, it is appropriate to investigate the 


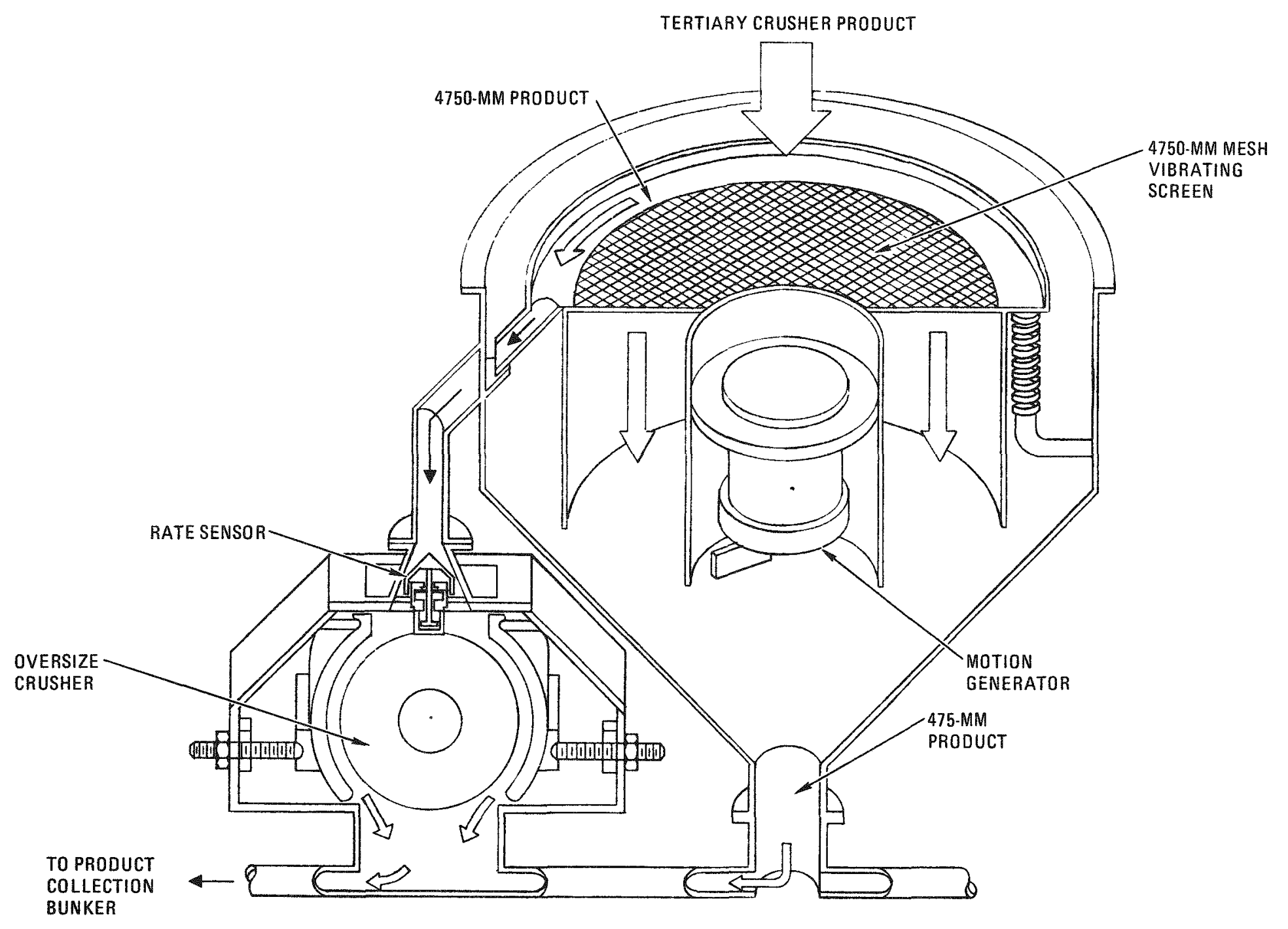

Fig. 8-5. Oversize monitoring system 


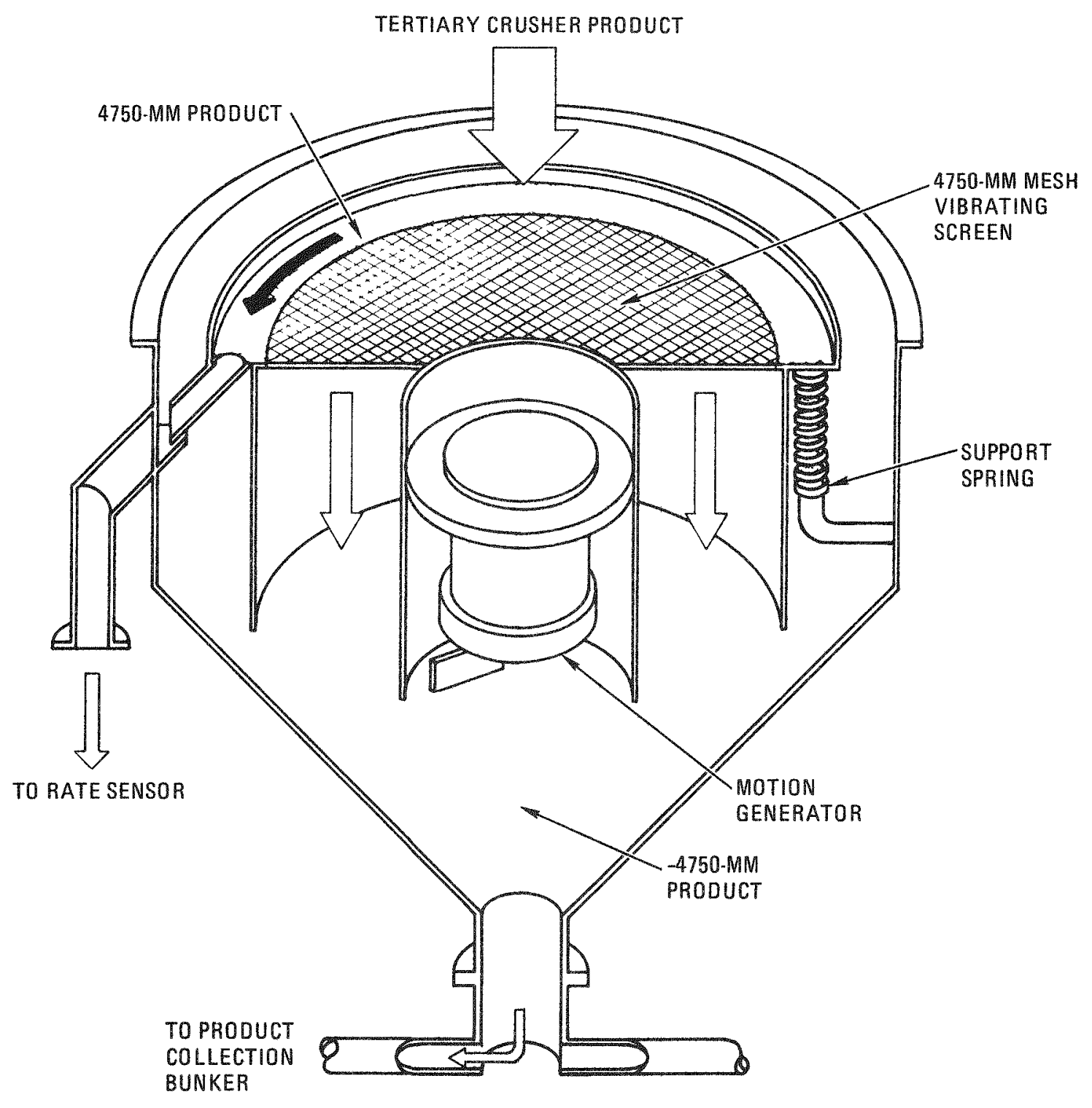

Fig. 8-6. Cutaway of screener 


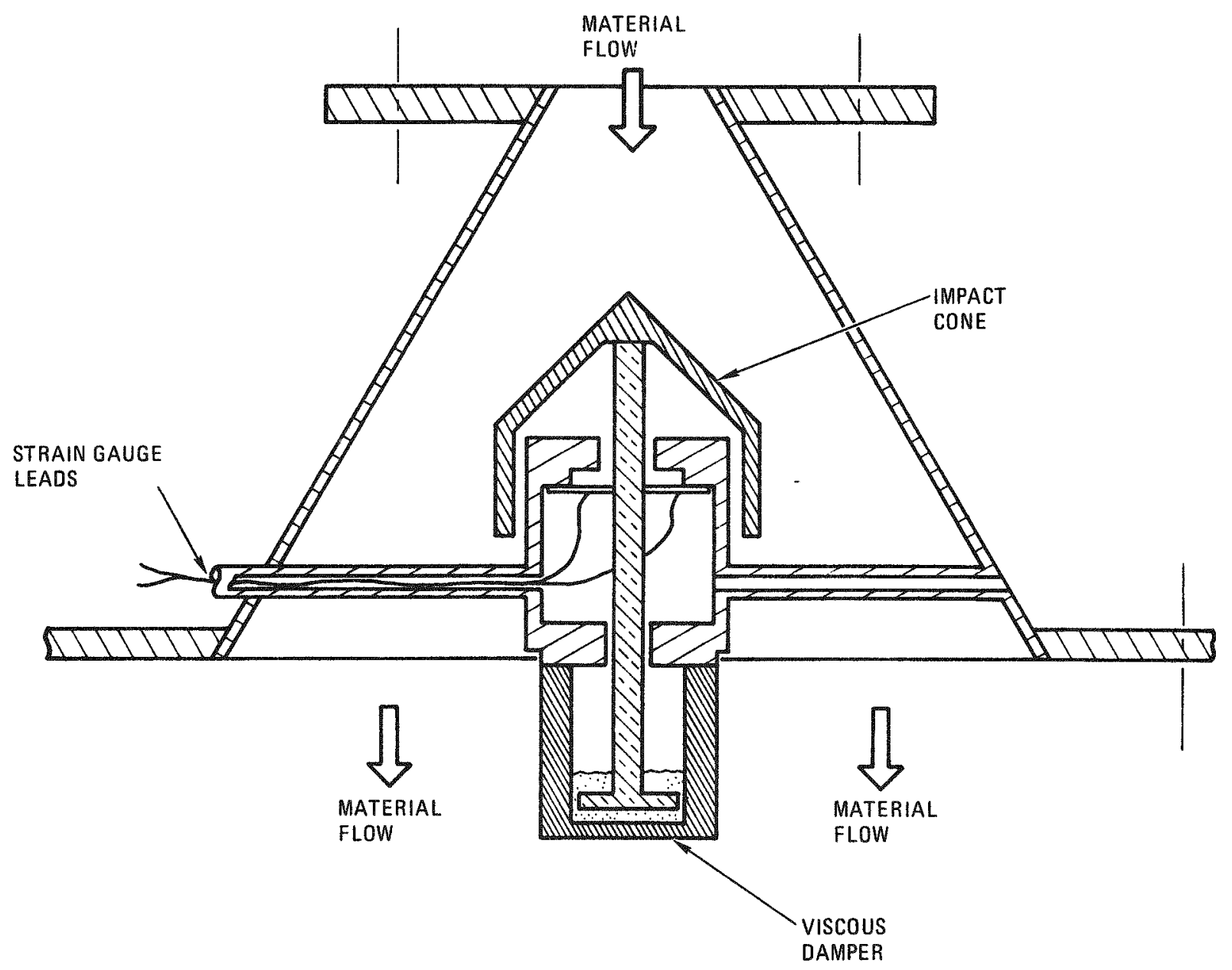

Fig. 8-7. Flow rate sensor 


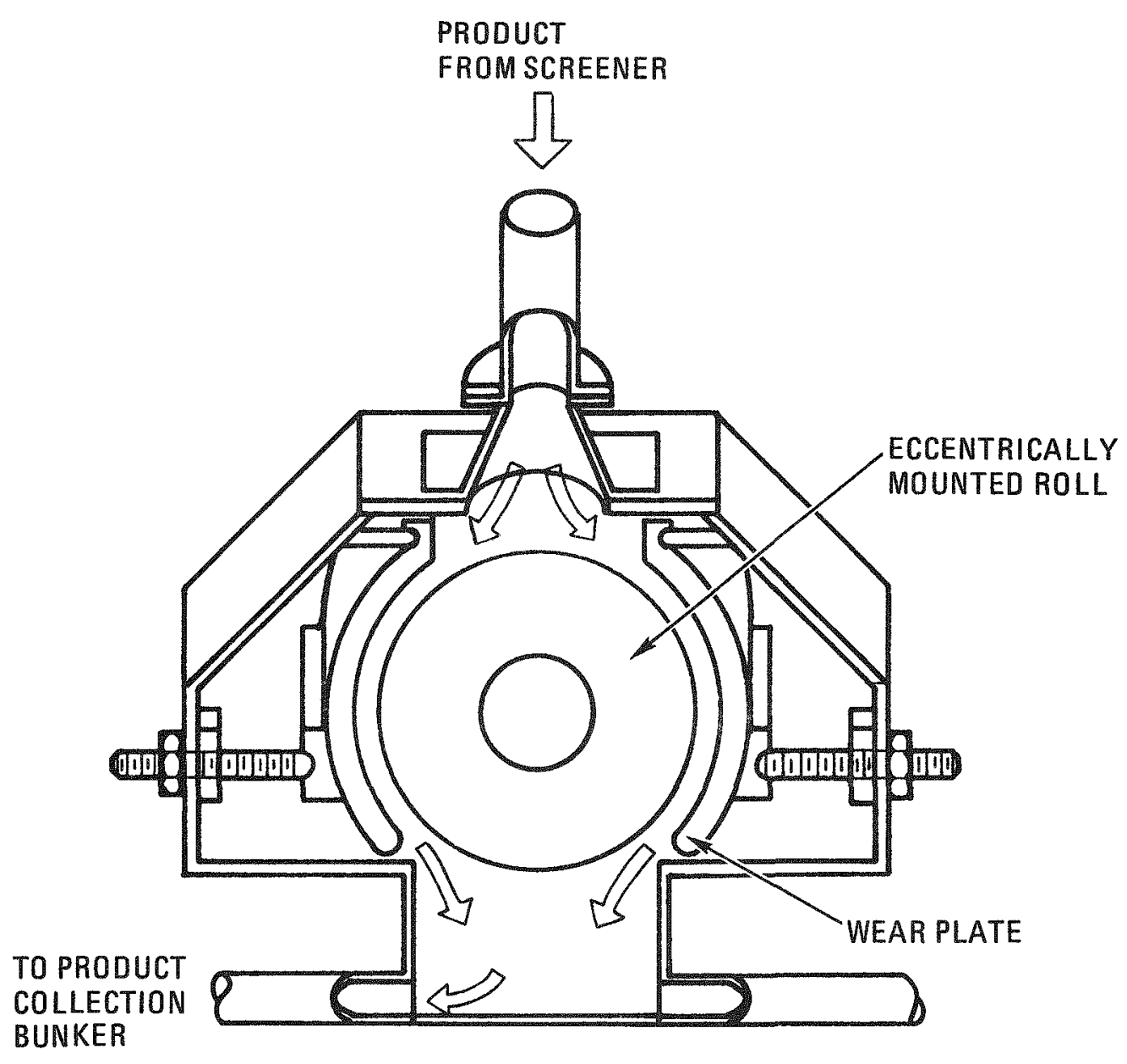

Fig. 8-8. Cutaway of oversize crusher 
potentials of alternatives owing to operating problems during system tests, the general complexity of the system, and the eventual need for remote fixtures for removing parts.

A perforated plate was initially tested (phase I) for use as the screening surface because of its potential for improving reliability (over a wire mesh screen) due to the greater strength of the perforated plate. Unfortunately, many of the holes in the perforated plate were blinded by lodged graphite particles. This situation was not sufficiently alleviated by chamfering the holes to reduce the length-to-diameter ratio or by replacing the perforated plate with a wire mesh screen. However, blinding was considerably reduced by the addition of a comercially available selfcleaning device. This device consisted of a perforated plate with holes sufficiently larger than the largest particle passing through the screen, rendering blinding of the plate impossible. The plate was mounted beneath the wire mesh screen and supported cylinders which bounce and rotate in the space between the plate and the screen to dislodge particles from the screen. Although blinding was reduced, it was not eliminated and increased in proportion to the quantity of material screened, indicating the eventual need for a maintenance plan or an alternative for correcting this undesirable condition.

During these and subsequent tests, it was found that the screener was discharging more than $5 \%$ of the acceptable product to the oversize product stream. Changes in the motion generator settings were unable to consistently reduce this screening inefficiency to the $\leq 5 \%$ level. The $4750-\mu \mathrm{m}$ wire mesh screen was temporarily replaced with a 6350-um wire mesh screen to determine how much the inefficiency could be reduced by a larger-mesh screen. The inefficiency was reduced to $20.1 \%$, but with the expected result of allowing some unacceptable $4750-\mu \mathrm{m}$ product to pass through the screen.

The motion generator settings for the $4750-\mu \mathrm{m}$ mesh screen which minimized its inefficiency resulted in a small residue of oversize product on 
the screen surface. This was caused by the motion of these particles toward the center of the screen imparted at this motion generator setting. In addition to this material holdup, there were small quantities of dust held up on the tops of the spring supports and within the ventilation enclosure transition betweenthe tertiary crusher and the screener housing. Dust containment within the enclosure and the screener housing was, however, complete. Throughout all the tests, no mechanical failures of the screen surface, the screener, its parts, or the housing were detected.

Tests on the oversize crusher revealed that it did not reduce all the oversize material discharged from the screener to $\leq 4750 \mu \mathrm{m}$. This was attributed to spring loading of the wear plates, which allowed them to be pushed away from the roll by the flow of material between the plates and the eccentric roll. Setting the gaps closer (which would be difficult to accomplish remotely under the present design) resulted in failure of the material to flow. There was little difference between the size distributions of the products which had only been through the tertiary crushing stage and those which had been through the entire system, indicating that the effect of the oversize crushing stage is minimal. As expected, fuel particle breakage in the oversize crusher product was generally higher than that in product which passed through the screen. However, since fewer particles passed through the oversize crushing stage, the effect of increasing particle breakage in the total product was small. The oversize rate monitor was not installed in the system because bench tests had shown it to be too sensitive for this application and in need of further development.

Three viable alternatives have been identified for the present oversize monitoring system: (1) complete omission of the oversize monitoring system, which would give the maximum reduction of parts; (2) replacement of the 4750- $\mu \mathrm{m}$ screen with a larger mesh size screen, which, as the tests showed, would minimize blinding and improve efficiency; and (3) replacement of the oversize monitoring system with an appropriately sized grate to remove material which could block the transport line or damage the burner. 
The present primary bumer feed requirements were estimated from previous tests on a smallermdiameter burner. The exact limitations on the current burnex's feed and the effects of small changes in feed size distribution on bumer operation are not known. If the overall size distribution gradually increases owing to wear on UNIFRAME components, transport and fluidization may slowly deteriorate in proportion to wear, indicating that replacement of worn components is required long before a catastrophic failure occurs to the burner or the transport system.

Past testing indicated that fuel particles do not exist as large agglomerates after fuel element crushing. Assuming that this is a continuing case, burner and transport problems from large dense masses of particles are also remote. The bumer feed could be periodically monitored by taking samples from the transport system. These samples would show the gradual changes in size distribution expected from wear of UNIFRAME components, large agglomerates of fuel particles, and large changes in size distribution. The present design does not guarantee that oversize material will not reach the bumer. However, burner tests on the actual products have revealed no problems to date.

Tests to date with unirradiated graphites have not been extensive enough to reveal wear on any of the UNIFRAME components, even those constructed of mild steel. Since wear rates have not been established for either unirradiated or Irradiated fuels, wear can only be assumed to be a problem, and inclusion of the oversize monitoring system is a precaution against wear and not an established need. Wear occurring in the primary and secondary crushers, if serious enough, would result in the inability of the succeeding crusher to crush the material. Therefore, it would not continue to the burner but would become holdup which could be detected by material balances. Wear occurring in the tertiary crusher would result in a gradual increase in the size distribution of its product. This product, if sent directly to the burner, would probably cause deterioration of fluidization in proportion to the change in size distribution. 
Unfortunately, the monitoring system has no means of monitoring wear in its own components. The results of wear in this system can be expected to have the same effects as unmonitored tertiary crusher wear. Periodic sampling of the transport system appears to be the only means of providing a precaution against wear in all components as well as determining the exact nature of the feed to the primary burner. For commercial operation, gross wear could be measured in the hot cell during schedule shutdowns. This would allow for adjustments or replacements prior to catastrophic failures, but would not preclude periodic sampling.

All postulated catastrophic failures of the crushers, such as bearing seizing, toggle fractures, drive failures, and shaft fractures, would probably result in the inoperability of the affected crusher, excessive vibration, shutdown, or other clearly detectable consequences. Since these failures would cause immediate shutdown, they do not require initial detection by a monitoring system to prevent detrimental effects on normal burner feed. Tramp metal from minor failures such as loose screws, bolts, and nuts could either pass through the screener into the transport system or enter the oversize crusher, where it could cause further damage or pass into the transport system. Tramp metal from the monitoring system itself would have similar consequences. Since tramp metal of sufficient size could not be transported at the velocities used for crushed fuel element materials, it could eventually lead to transport line blockages, which would be less devastating and easier to correct than burner failures due to tramp metal. However, the complete exclusion of transportable tramp metal cannot be assured in any system. It must be diligently avoided in all designs, inspections, and preventative maintenance practices.

The reliability of components in series, such as the crushing components of the UNIFRAME oversize monitoring system, is commonly expressed as $R_{s}=R_{1} \times R_{2} \times \ldots R_{n}$, where $R_{s}$ it the total system reliability, and $R_{1}$, $R_{2} \ldots R_{n}$ are the individual reliabilities of the components. Therefore, elimination of a component in the series or improvement of a component's 
reliability must improve the reliability of the total system. This is the case for mechanical reliability of the UNIFRAME. However, if the improvements in mechanical reliability change the product characteristics, the true reliability may not, in fact, be improved. This aspect of system reliability should not be ignored and cannot be sacrificed at the expense of improving mechanical reliability. Access to UNIFRAME components to repair failures would probably be improved by simplification or elimination of the oversize monitoring system. This does not mean that the necessary access could not be achieved in any design.

The additional penetrations, separations, and remote tooling required for the ventilation enclosure by the present oversize monitoring design increases the probability of failures in these areas. Simplified designs could reduce the probability of these failures. It is possible that failures could occur which would be impossible to repair with the remote tools readily available. This could result in long delays or necessitate removal of the entire UNIFRAME system. These failures are possible with any system, but are more likely with complex designs.

The designs for remote removal fixtures and tools are not complete. Additional fixtures required for removal of parts will be subject to failure and will require tooling for repairs. Failure of remote tools could render them unavalable when they are needed. The additional cell floor space necessary for remote removal of components and the storage area requirements for replacement parts and remote tools cannot be determined until all the designs are complete. However, these requirements would be greater and more costly for the more complex removable components.

The wear tests recommended for establishing data for decisions regarding fixed versus removable stationary jaw designs should provide information which can be used to estimate the effects of wear on production of burner feed and to establish guidelines for periodic in-cell wear measurements and component replacement prior to wear-out, if required. Since (1) any oversize monitoring system will be subject to wear and faflure and cannot monitor itself and (2) changes in product size distribution occur in 
transport, a sampler should be installed to provide information on these phenomena. The sampler should be located at a point after the UNIFRAME product discharge and should be compatible with transport and burner requirements. Since the present primary burner feed requirements have been estimated and the limitations are not definitely known, more information is needed for sound design decisions regarding the preparation of feed.

To prepare burner feed, fueled elements should be crushed in the UNIFRAME without the oversize monitoring system. Analysis of the size distributions of the products will provide data on operating parameter differences and problem areas from burning in the primary burner. This should establish the feasibility of using tertiary crusher product as primary burner feed.

The designs of the screener, the oversize crusher, and the rate monitor should be optimized, and investigations should be made on alternative methods of (1) reducing dust retention, screen blinding, and material holdup on the screen surface, (2) reducing dust retention in the oversize crusher by providing an easily controlled gap setting, (3) reducing particle breakage in the oversize crusher, and (4) measuring the amount of oversize product which remains after tertiary crushing. To avoid difficulties with tramp metal, all sources of problems, such as bolts, nuts, screws, etc., inside the ventilation enclosure, should be avoided in the design or provided with secondary capture methods such as lock washers, thread compounds, or welding.

The decision to use one of the altemative designs or the present oversize monitoring system must be based on (1) the suitability of the tertiary crusher product as primary burner feed (this should be obtained from actual burnex tests); the results of wear tests, and (3) failure modes and effects analysis of all the completed designs, including analysis of effects on the transport system and the primary burner and protection provided by a sampler located before the burner. If the tertiary crusher 
product is found to be unsuitable for use as primary bumer feed, installation of a grate or removal of the oversize monitoring system would be eliminated from consideration as design altematives because they provide no means of altering the tertiary crusher product. The size of the screen openings and the risk of installing a larger-mesh screen can be assessed from changes of bumer operating parameters and problem areas arising from the unsuitability of the tertiary crusher product as feed. If the tertiary crusher product is found to be suitable for primary burner feed, all alternative designs as well as the present oversize monitoring system can be considered for inclusion in the UNIFRAME system. The need for the oversize monitoring system and the larger-mesh screen concept would be reduced, but further assessment based on wear rates and failure modes and effects analysis would be required for the final determination.

If the tests show that the potential wear is high, a maintenance plan for wear measurement and replacement of components prior to wear-out would be formulated. Since the oversize monitoring system components are subject to the same wear conditions as the rest of the systems but are unmonitored, the downstream sampler and maintenance plans for wear measurement and component replacement are applicable to these components regardless of screen size. Therefore, high wear does not preclude omission of the oversize monitoring system. The need for the present oversize monitoring system and its larger-mesh altemative would be reduced if wear rates were low, but the failure modes and effects analysis would have to be used to determine whether intolerable conditions exist.

If the tertiary crusher product is suitable for use as primary burner feed and construction materials which have reasonable wear rates are used, there are a large number of advantages of removing the oversize monitoring system (pending, of course, a favorable failure modes and effects analysis). The grate concept has few advantages because it only excludes large fragments of graphite and tramp metal, provides essentially no change in the product, must be inspected, and can cause unnecessary blockages from 
product bridging. The larger mesh screen in the present oversize monitoring system improves efficiency, reduces particle breakage, and reduces blinding. It is preferable to the current screen if problems and changes in burner operation are not severe and assuming that the tertiary crusher product is unsuitable for use as feed (thereby excluding omission of the system).

\subsection{SUMMARY}

The present design of the fuel element size reduction system has been proven to be adequate for producing feed suitable for burning in a fluid bed burner under cold pilot plant conditions. However, prior to use in a commercial fuel reprocessing facility in a hot cell environment, the design will require upgrading to be compatible with the more severe operating conditions. Some of these design refinements were identified at the onset of the initial design but were not developed because of budgetary and scheduling considerations and to allow confirmation of design concepts by testing. The need for other refinements was discovered during system and component tests. These design requirements are

1. Modification of the ventilation enclosure to integrate it with the machine frame and to provide compatibility with remote remova1.

2. Replacement of current wear surfaces with hardened materials.

3. Provision of a through-the-cell-wall drive system.

4. Provision of start-under-load capabilities.

5. Provision of a fuel loading port.

6. Modification of lubrication systems for compatibility with remote operations and a high-radiation environment. 
7. Provision of interchangeable pitman parts.

8. Provision of a secondary crusher clearing device.

9. lodification or replacement of oversize crusher to ensure $\leq 4750-\mu \mathrm{m}$ product, remote gap adjustment, and minimum material holdup.

The following design changes are recommended for the final commercial facility design in addition to a comprehensive review of the entire UNIFRAIE design for tramp metal sources:

1. Primary crusher with the smallest practicable fixed nip angle.

2. Shim adjustments for the primary and secondary crusher CSS.

3. Provision of UNIFRAME product sampler.

It is also recommended that the following designs be completed at the same time as wear and burner feed tests and be followed by failure modes and effects analysis for final evaluation:

1. Primary crusher clearing device.

2. Primary and secondary crusher fixed and semifixed stationary jaws.

3. Optimum screener.

4. Alternative rate monitor. 


\section{ACKNOWLEDGMENTS}

The authors wish to thank B. J. Baxter, project engineer, C. M. Miller, and E. J. Cook, whose combined efforts provided the design for the UNIFRAME. Thanks are also due to the entire staff of GA technicians for their expert assistance in testing the UNIFRAME and to J. W. Baer for his continued work in upgrading designs and solving problems encountered during the test program. 


\section{APPENDIX A}

DESIGN CRITERIA FOR FUEL ELEMENT SIZE REDUCTION SYSTEM 


\section{GENERAL ATOMIC COMPANY}

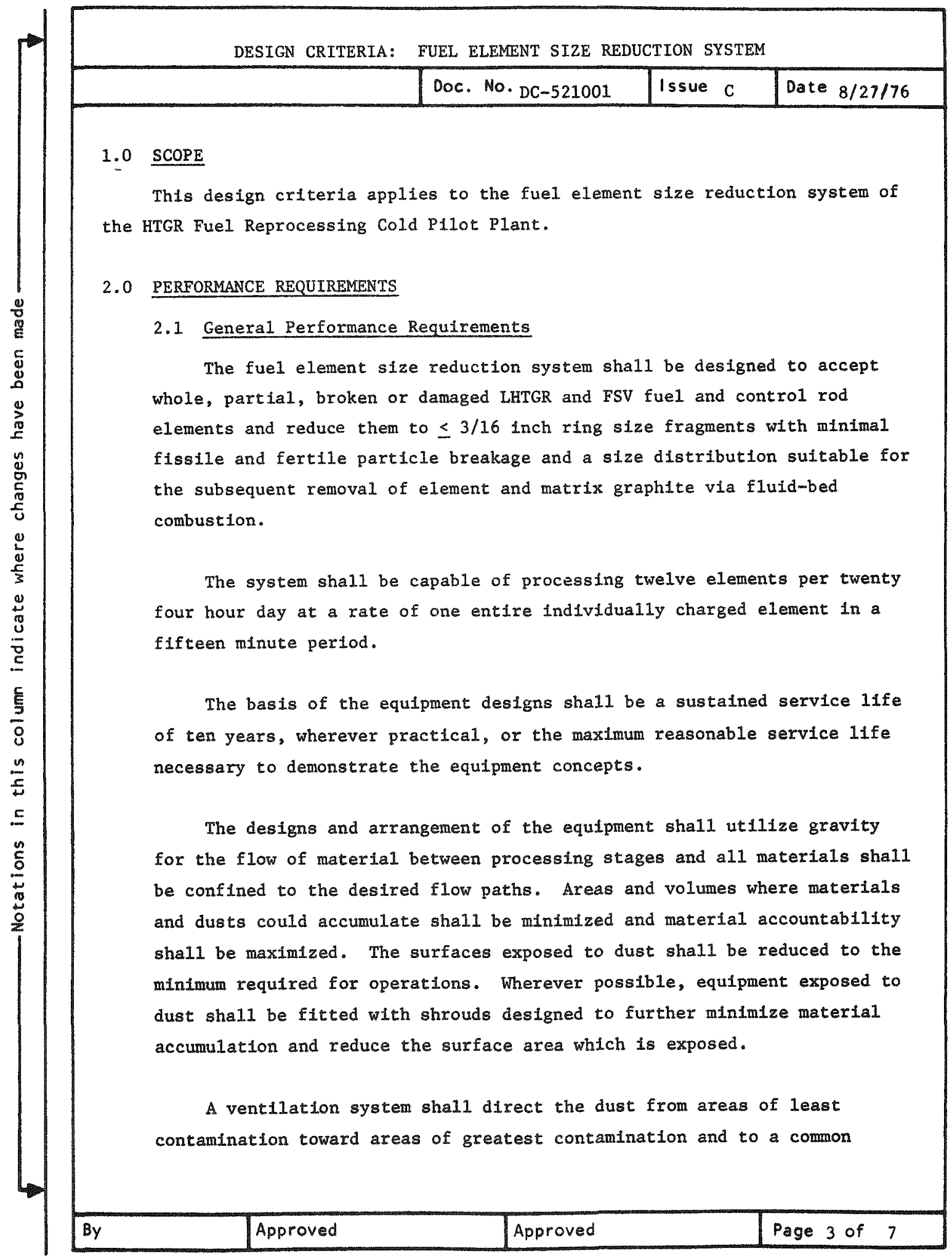


GA $541(\operatorname{Rev} 5 / 74)$

\section{GENERAL ATOMIC COMPANY}

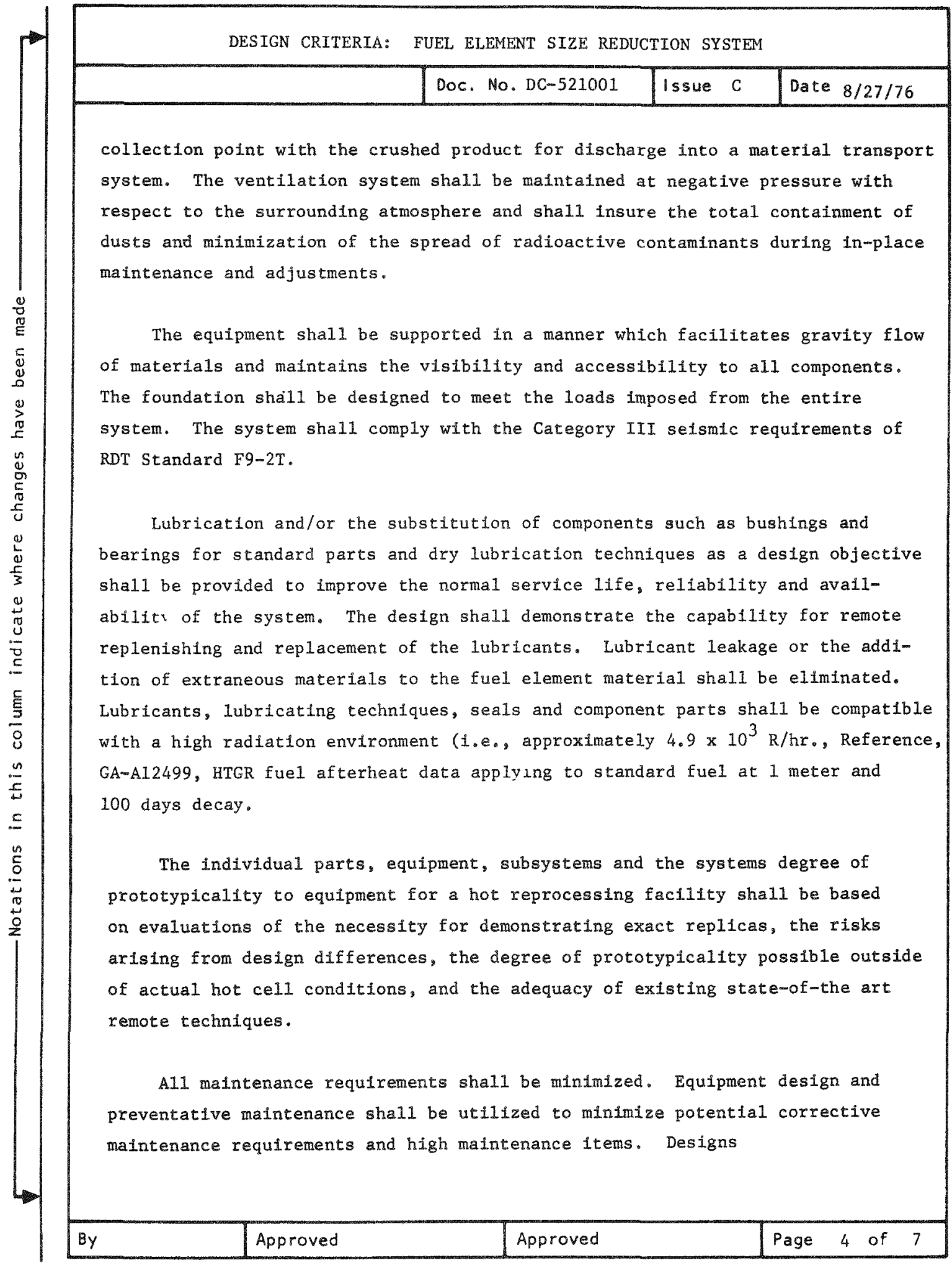


GENERAL ATOMIC COMPANY

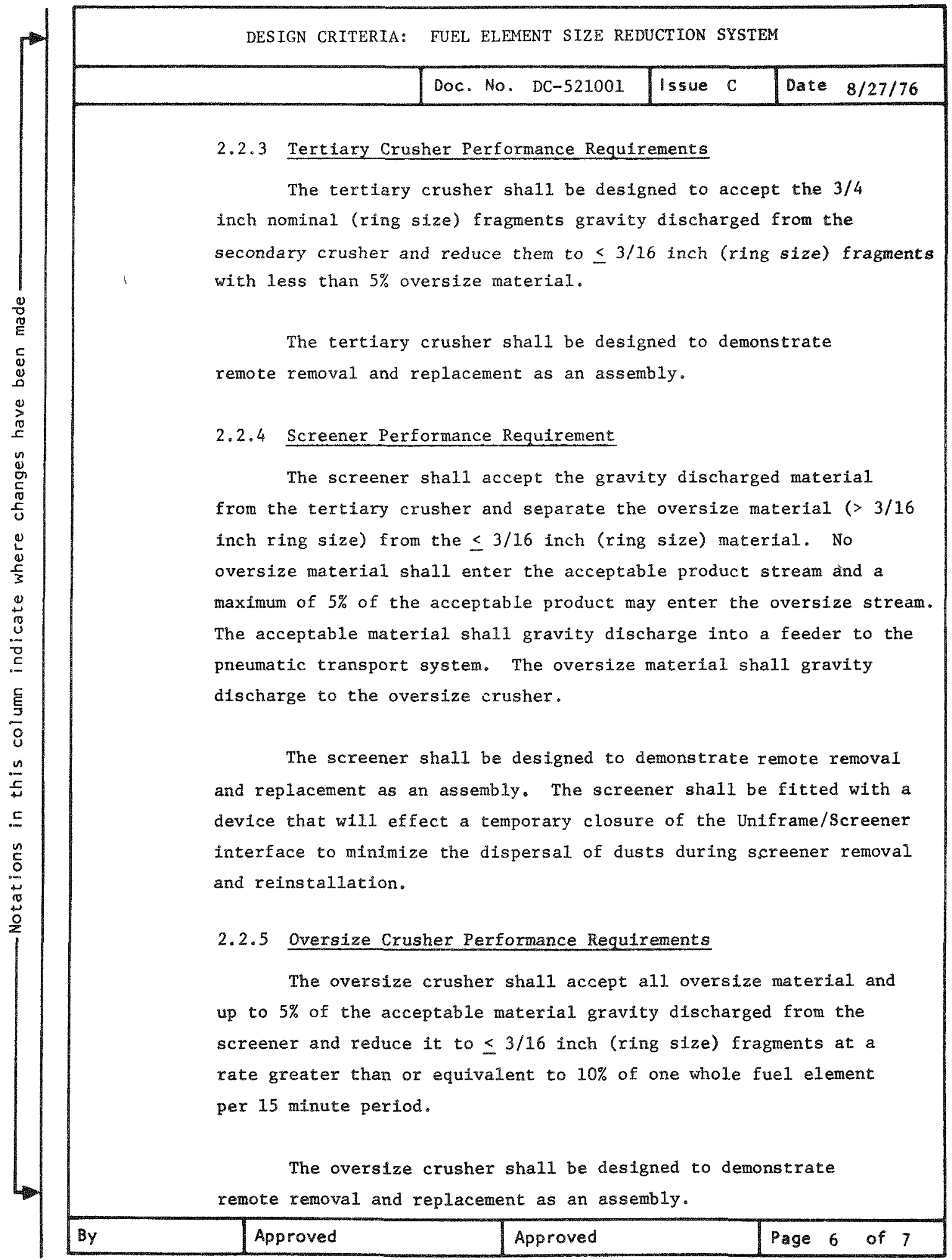




\section{GA 541 (Rev 5/74) GENERAL ATOMIC COMPANY}

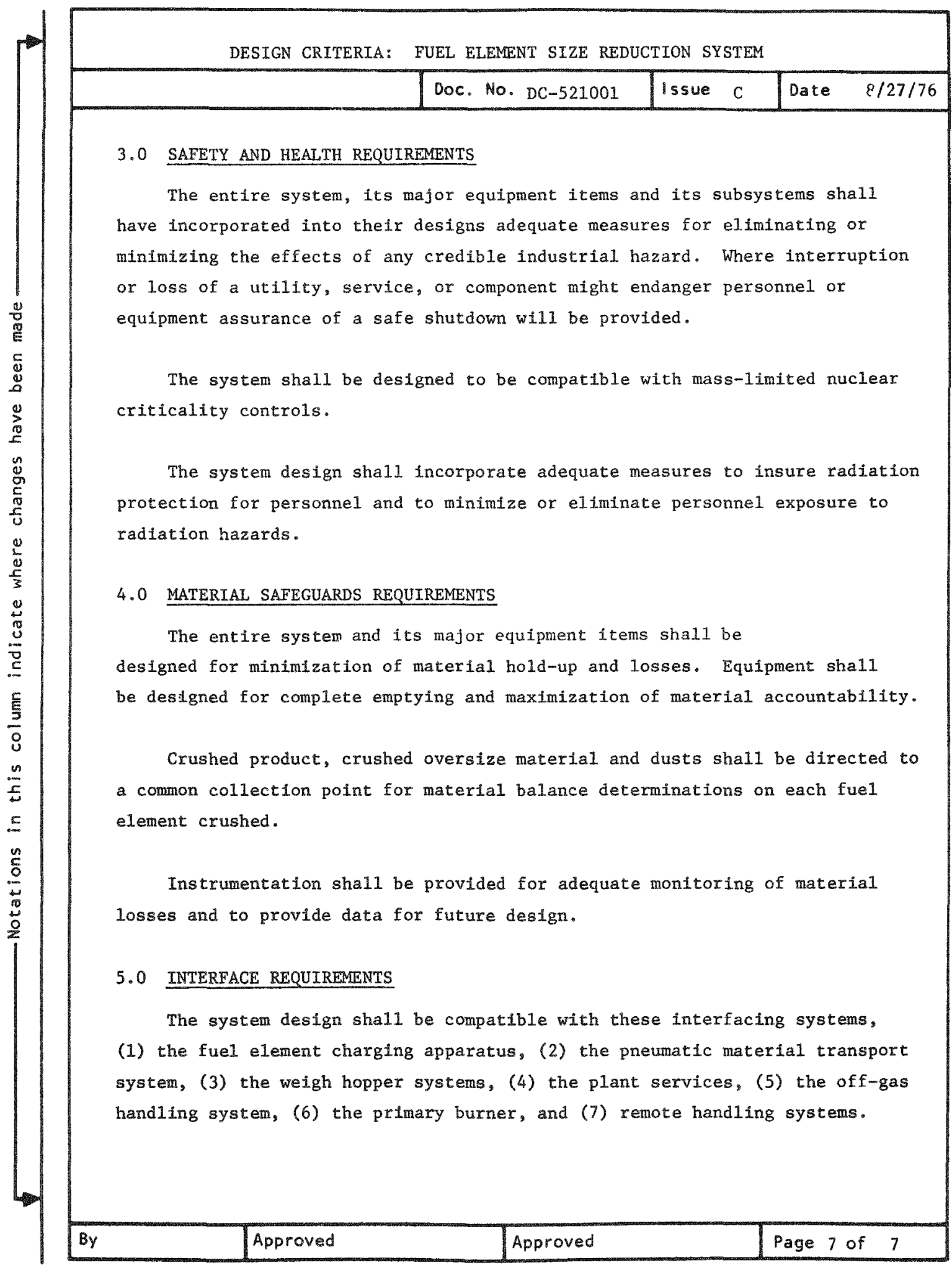

